Steffi Heinrichs

Response of the understorey vegetation to selection cutting and clear cutting in the initial phase of Norway spruce conversion
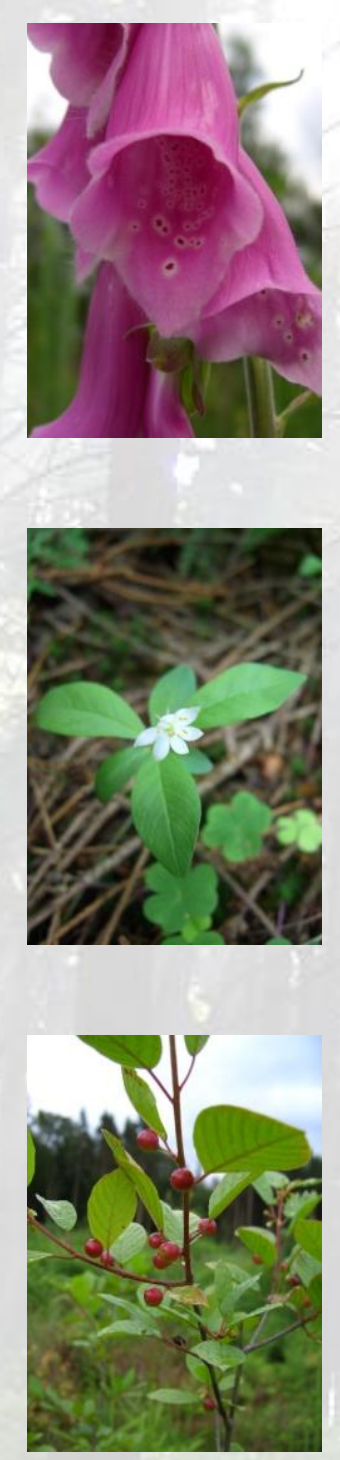

Georg-August-Universität Göttingen 

GÖTTINGER ZENTRUM

FÜR BIODIVERSITÄTSFORSCHUNG UND ÖKOLOGIE

- GötTINGen CEnTRe For BiodiverSity AND ECOLOgy -

\title{
Response of the understorey vegetation to selection cutting and clear cutting in the initial phase of Norway spruce conversion
}

\author{
Dissertation zur Erlangung des Doktorgrades der \\ Mathematisch-Naturwissenschaftlichen Fakultäten der \\ Georg-August-Universität Göttingen
}

\author{
vorgelegt von \\ Dipl.-Biologin \\ Steffi Heinrichs \\ aus \\ Zerbst/Anhalt
}


Referent: Prof. Dr. Wolfgang Schmidt Korreferent: Prof. Dr. Friedrich Beese

Tag der mündlichen Prüfung: 17. März 2010 


\section{Table of Contents}

Danksagung

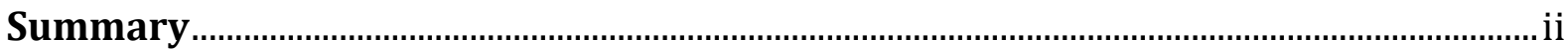

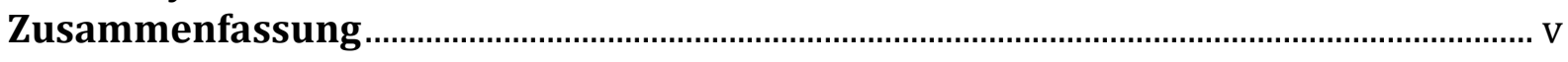

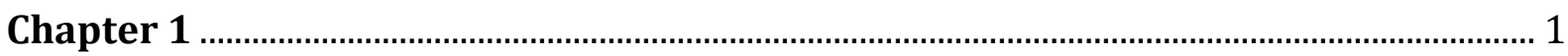

Introduction

Chapter 2

The study area

Chapter 3

Short-term effects of selection and clear cutting on the shrub and herb

layer vegetation during the conversion of even-aged Norway spruce

stands into mixed stands

Steffi Heinrichs \& Wolfgang Schmidt (2009) Forest Ecology and Management 258: 667-678.

\section{Chapter 4}

4.1.

The estimation of aboveground biomass and nutrient pools of understorey plants in closed Norway spruce forests and on clear cuts Steffi Heinrichs, Markus Bernhardt-Römermann \& Wolfgang Schmidt (2010) European Journal of Forest Research 129: 613-624.

4.2 79

Changes in aboveground biomass, in nitrogen accumulation and in resource use related plant traits after clear and selection cutting in Norway spruce stands

Steffi Heinrichs, Uwe Klinck \& Wolfgang Schmidt: Manuscript

Chapter 5 .

On the potential of the soil seed bank to facilitate or constrain Norway spruce conversion

Steffi Heinrichs \& Wolfgang Schmidt: Manuscript

\section{Chapter 6}

Synthesis

Appendices 



\section{Danksagung}

Viele haben zum Gelingen der vorliegenden Arbeit beigetragen; bei ihnen allen möchte ich mich an dieser Stelle bedanken:

Als erstes ist dabei Prof. Wolfgang Schmidt zu nennen. Ihm bin ich für die Betreuung der Arbeit, die hilfreichen Ratschläge und konstruktiven Ideen, die schnelle und kritische Durchsicht der Manuskripte und vor allem für die gelassene Freiheit und das Vertrauen bei der Durchführung der Arbeit sehr dankbar. Bei Prof. Friedrich Beese bedanke ich mich herzlich für die Übernahme des Korreferats.

Ein großer Dank geht an alle aktuellen und ehemaligen Mitarbeiter der Abteilung Waldbau und Waldökologie der gemäßigten Zonen, auf die bei diversen Labor- und Feldeinsätzen aber auch bei bürokratischen Dingen immer Verlass war und die immer für eine angenehme Arbeitsatmosphäre sorgten. Mein besonderer Dank gilt: Andreas Parth, dem Retter in jeglicher Computer-Not, für die vielen aufbauenden Worte und lustigen Mensa-Gänge; Andrea Bauer für die vielen Gespräche nicht nur während des Fichten Entnadelns; Heiko Rubbert für die unermüdliche Einsatzbereitschaft im schönen Solling und Markus Bernhardt-Römermann für die konstruktiven Vorschläge während der Datenerhebung und -auswertung. Vielen Dank auch an meine DoktorandenKolleginnen Sabine Budde, Michaela Dölle, Bettina Stoll und Theresa Waldmann für nette Stunden auch außerhalb der Uni. Meiner Zimmergenossin Michaela danke ich für die nette Atmosphäre im Büro, das Korrekturlesen und das Erdulden vieler Fragen beim „Gegenübersitzen“, Resa für die Hilfe bei Freilandarbeiten und für ihre Freundschaft.

Dem Forstamt Neuhaus danke ich für die Erteilung der Fahrgenehmigung, den Mitarbeitern der Nordwestdeutschen Forstlichen Versuchsanstalt für die Einrichtung und ständige Instandhaltung der Flächen. Dankbar bin ich auch meinen „HiebsformenKollegen“ Uwe Klinck, Catalin und Ana Petritan und Daniel Fröhlich. Sie auf den Flächen zu treffen sorgte für Abwechslung an langen Freiland-Tagen. Besonders dankbar bin ich Uwe Klinck, der Fragen nach diversen Zahlen immer sofort beantwortet hat und den Informationsfluss im Projekt „am Laufen hielt“. Vielen Dank auch an Thomas Kompa, nicht nur für die Datenaufnahme „vor meiner Zeit“.

Ein ganz herzlicher Dank gilt all meinen Freunden außerhalb der Uni, die immer ein offenes Ohr hatten, und meiner Familie, ganz besonders meiner Mama, die immer für mich da ist. 


\section{Summary}

The conversion of pure Norway spruce (Picea abies (L.) Karst.) stands into mixed stands with site adapted tree species is the main challenge of silviculture in Central Europe nowadays. The conversion will primarily be achieved by applying a target diameter selection cutting regime creating small gaps. Larger gaps up to small scale clear cuttings will be avoided and are only an option at sites prone to windthrow or drought. Especially clear cutting with its severe disturbance is thought to cause negative effects on late-successional plant and animal species and to disrupt ecosystem processes like nutrient cycling, whereas the removal of single trees equals moderate natural disturbances and maintains a multifunctional forest ecosystem.

In the framework of the present thesis the response of the understorey vegetation to these two opposing management strategies in the first five years after harvesting was analysed in order to assess the appropriateness of these management strategies for spruce conversion. A before/after-control/impact experiment established in the Solling Hills, Germany, provided the basis for this. The Solling is a large forest ecosystem naturally vegetated by acidic beech forests. Today the artificially introduced Norway spruce is dominant. The experiment was established at two study sites differing slightly in climate, stand age, land use history and liming regime.

The consideration of the understorey vegetation is an important task as it contributes largely to forest biodiversity. Depending on scale and severity of harvesting operations, the understorey can negatively affect the future forest development when the expansion of competitive grass and shrub species inhibits the colonization, establishment, and growth of desired tree species. Conversely, it can positively influence ecosystem functioning after disturbance by an effective and early coupling of forest floor decomposition and nutrient uptake by fast growing vegetation.

A first study regarded the response of the shrub and herb layer in terms of species diversity and composition. After both treatments an immediate increase in plant species diversity and abundance was detected compared to a temporal reference. This increase is reflected in a rise in competitive forest generalists, open site species, and tree species with clear cutting plots showing highest numbers. Species with a short-life cycle were, however, longer persistent after selection cutting. Though selection cutting resulted, in contrast to clear cutting, in a forest community more similar to the community detected on control plots, a qualitative loss in closed forest species was found following neither treatment. Moreover, the increase in species with a competitive strategy did not deter 
tree species from regenerating in the clear cut plots. On selection cutting plots, though, a persistent moss layer, an expansion of Rubus idaeus and a lower light availability supported an only lower diversity and abundance in tree species.

An increasing abundance of large growing competitive species accompanied by a higher degree of flowering can increase nutrient retention due to an increased plant uptake. Thus, the understorey was as well analysed regarding changes in aboveground biomass and nitrogen content. For the determination of these parameters the estimation model PhytoCalc was used. This model allows a non-destructive quantification of aboveground biomass and nutrient pools of forest understorey plants by using the relationship between species biomass, cover and shoot length. The model has been validated with independent samples in several German forest types; under clear cut conditions though, it underestimates biomass values and gives unreliable nutrient pool estimations. Tissue density, approximated by the leaf dry matter content (LDMC), is generally higher under high light compared to low light conditions. Thus, the ratio of LDMC under clear cut to LDMC under forest conditions was used as a correction factor to adjust the PhytoCalcmodel to clear cut conditions. A 60 to $90 \%$ fit between observations and predictions for five exemplary species was achieved. Besides, significantly different correction factors regarding morphological growth groups could be detected. These correction factors were used to estimate biomass and nitrogen contents of the understorey with PhytoCalc on clear cuts. The original model was applied on control and selection cutting plots. Recently, also allometric equations for tree regeneration species in forests were developed, which were also used during this study. On clear cuts, new equations were derived. By applying existing and new allometric functions, estimated biomass and nitrogen values under forest and clear cut conditions were determined, which are in accordance with other studies conducted across Central Europe.

Both harvesting treatments induced a clear increase in biomass and nitrogen content of the understorey vegetation, with highest values detected again on clear cuts. This implies a larger nitrogen availability and uptake following clear cutting. The development of plant traits related to a fast nutrient uptake and growth rate (i.e. a high specific leaf area, an herbaceous growth form and the occurrence of nitrophilous species) supports this. In addition, these functional groups seem to mitigate nitrogen losses after harvesting. However, already in the first five years after clear cutting a shift of plant species with an exploitive strategy regarding resource use to species with a conservative strategy was found, which is in accordance with a nitrogen 
impoverishment detected in the soil and the plant tissue and is the result of a persistent plant growth under a high light availability. The immediate response after selection cutting was similar, but not as pronounced. A lower light availability and persistent mosses deterred an expansion of nitrophilous species and tree regeneration, causing higher inorganic nitrogen concentrations in the soil solution measured under gaps compared to control plots and clear cuts over the whole study period. The response regarding resource use indicators was faster at the more recently limed study site, where a larger pool of, in part nitrophilous, herb layer species was able to expand under changed environmental conditions.

A last study examined the potential influence of the soil seed bank on Norway spruce conversion. Results showed that the soil seed bank influenced the post-harvest communities after both treatments mainly regarding Carex plulifera and Juncus effusus, which are known to form a long-persistent seed bank. The risk of dreaded competitive species (e.g. Calamagrostis epigejos, Rubus species) from the seed bank, which are able to suppress the secondary succession process, is low for mature spruce stands. A seed accumulation of competitive species can, however, cause problems with a recurrent disturbance regime such as selection cutting. An early and successful integration of desired tree species is therefore important to have a growth advantage over such species. Closed forest species only formed transient seed banks; however, some ancient forest species which are characteristic for the naturally occurring acidic beech forests were frequently detected within the seed bank and can contribute to the upcoming forest understorey community.

In conclusion, results of the present work could detect no overall negative short-term effects of small scale clear cuttings on understorey diversity, tree regeneration or nitrogen leaching in the Solling compared to single tree selection cutting. Specific site conditions regarding understorey composition should however be taken into account as the expansion of species potentially inhibiting tree regeneration depends largely on the vegetation present before disturbance, whereas the seed bank under mature spruce stands plays only a minor role. Thus, small scale clear cutting can be an appropriate complement to more moderate disturbance regimes and offer colonization sites for a diverse tree regeneration. By applying a mosaic of management regimes, structural as well as species diversity at a small and landscape scale could be increased and climateadaptive forests be produced. 


\section{Zusammenfassung}

Die Umwandlung von Fichtenreinbeständen in Mischbestände aus standortsgerechten Baumarten ist eine der waldbaulichen Hauptaufgaben in Mitteleuropa. Es sollen Bestände geschaffen werden, die den Anforderungen des Klimawandels gewachsen sind. Die Umwandlung wird hauptsächlich mit Hilfe von Zielstärkennutzung erfolgen, bei der die einzelstammweise Fichtenernte kleinflächige Lücken erzeugt. Größere Lücken bis hin zu kleineren Kahlschlägen sollen nur in stark störungsanfälligen Beständen auf wechselfeuchten bzw. trockenen Standorten angewendet werden. Die vollständige Entfernung des Kronendaches stellt eine erhebliche Störung dar, die sich vermeintlich negativ auf spät-sukzessionale Pflanzen- und Tiergemeinschaften auswirkt und ökosystemare Prozesse, wie Nährstoffkreisläufe, aus dem Gleichgewicht bringen kann. Die Entnahme einzelner Bäume soll sich hingegen einem moderaten natürlichen Störungsregime annähern, welches ein multifunktionales Waldökosystem aufrecht erhält.

Im Rahmen der vorliegenden Arbeit wurde die Reaktion der Bodenvegetation auf die Durchführung dieser zwei genannten gegensätzlichen Hiebsformen in den ersten fünf Jahren nach der Holzernte beobachtet, um Aussagen über die Anwendbarkeit beider Methoden für den Waldumbau treffen $\mathrm{zu}$ können. Ein Vorher/NachherKontrolle/Eingriff-Experiment, welches in zwei, sich im Klima, im Bestandesalter und in der Nutzungs- und Kalkungsgeschichte unterscheidenden, Gebieten des Sollings eingerichtet wurde, bot die Möglichkeit dazu. Der Solling ist seit Jahrtausenden von Wald geprägt, wobei bodensaure Buchenwälder die natürliche Vegetation darstellen. Heute wird dieses Gebiet jedoch von der künstlich eingebrachten Fichte dominiert.

Die Betrachtung der Bodenvegetation ist von großer Bedeutung, da sie erheblich zur Biodiversität von Waldökosystemen beiträgt. Je nach Grad und Ausmaß forstwirtschaftlicher Störungen, kann sich die Bodenvegetation negativ auf die zukünftige Bestandesentwicklung auswirken, wenn die Ausbreitung konkurrenzstarker Gras- und Straucharten die Besiedlung, Etablierung und das Wachstum gewünschter Baumarten verhindert. Die Bodenvegetation kann Ökosystemprozesse nach Störungen aber auch positiv beeinflussen, indem eine schnelle und effektive Kopplung von Nährstoffmineralisierung und -aufnahme durch eine schnell wachsende Vegetation erreicht wird.

Eine erste Studie beschäftigte sich zunächst mit der Entwicklung der Strauch- und Krautschicht nach beiden Maßnahmen hinsichtlich der Artendiversität und 
-zusammensetzung. Beide Hiebsformen führten zu einer Erhöhung der Artenzahlen und des Deckungsgrades der Vegetationsschichten, die sich im vermehrten Auftreten konkurrenzstarker Generalisten, Offenland-Arten und sich verjüngender Baumarten ausdrückt. Kahlschlagflächen waren dabei in der Regel artenreicher als die Flächen nach Zielstärkennutzung. Kurzlebige Arten waren jedoch auf letzt genannten Flächen länger $\mathrm{zu}$ finden. Obwohl die Flächen nach Zielstärkennutzung im Vergleich zu Kahlschlagflächen von einer Vegetationsgemeinschaft gekennzeichnet waren, die der in Kontrollbeständen ähnlich ist, konnte auch nach Kahlschlag kein qualitativer Verlust an Arten, die an geschlossene Wälder gebunden sind, festgestellt werden. Die Ausbreitung konkurrenzkräftiger Arten verhinderte auch nicht die Ansiedlung von Baumarten auf Kahlschlägen, wohingegen eine überdauernde Moosschicht, die Ausbreitung von Rubus idaeus und eine geringere Lichtverfügbarkeit eine arten- und deckungsärmere Baumartengemeinschaft auf Flächen der Zielstärkennutzung bedingte.

Insbesondere die höhere Abundanz hochwüchsiger, konkurrenzkräftiger Arten in Verbindung mit einer verstärkten Ausbildung von Blütenständen kann den Verlust an Nährstoffen nach aufgetretener Störung durch eine erhöhte Nährstoffaufnahme verringern bzw. komplett verhindern. Daher wurde die Bodenvegetation auch hinsichtlich der Veränderungen in der oberirdischen Biomasse und des Stickstoffvorrates betrachtet. Für die Bestimmung dieser beiden Größen wurde das Schätzmodell PhytoCalc eingesetzt. Dieses Modell ermöglicht eine zerstörungsfreie Bestimmung der oberirdischen Biomasse und Nährstoffvorräte von Wald-Arten, indem die Beziehung zwischen der Biomasse einer Art, ihres Deckungsgrades und ihrer Sprosslänge in Form allometrischer Funktionen genutzt wird. Das Modell wurde bereits erfolgreich mit Hilfe unabhängiger Daten in verschiedenen deutschen Wald-Typen validiert; unter Kahlschlagbedingungen unterschätzte es die Biomasse verschiedener Arten jedoch deutlich und lieferte unzuverlässige Nährstoffvorräte. Die Gewebedichte, die annähernd durch den Trockensubstanzgehalt (Leaf Dry Matter Content; LDMC) quantifiziert werden kann, ist in der Regel höher unter voller Belichtung im Vergleich zu einer geringeren Lichtverfügbarkeit. Aus diesem Grund wurde das Verhältnis aus LDMC unter Kahlschlag zu LDMC unter Waldbedingungen als Korrekturfaktor genutzt um das PhytoCalc-Modell an Kahlschlag-Bedingungen anzupassen. Mit Hilfe dieser Korrektur konnten modellierte Biomasse-Werte für fünf Beispiel-Arten zwischen 60 und 90 \% der Varianz der beobachteten Werte erklären. Für morphologisch ähnliche Wuchsgruppen wurden ebenfalls signifikant verschiedene Korrekturfaktoren gefunden. Diese wurden 
auf den Kahlschlagflächen des Sollings angewendet um Biomasse und Nährstoffvorräte der Bodenvegetation zu bestimmen. Das ursprüngliche PhytoCalc-Modell wurde auf Kontroll- und Zielstärkennutzungsflächen angewendet. Seit jüngster Zeit gibt es auch allometrische Funktionen zur Biomasse-Schätzung der Verjüngung in Wäldern. Diese wurden ebenfalls während dieser Studie angewendet, während auf Kahlschlägen neue Funktionen ermittelt wurden. Die anhand der Nutzung bereits vorhandener und neu ermittelter allometrischer Funktionen bestimmten Biomasse und Stickstoffvorräte der Bodenvegetation auf Kontroll-, Zielstärken- und Kahlschlagflächen entsprachen Werten, die im Zuge anderer Studien in Mitteleuropa ermittelt wurden.

Auf beide Hiebsformen reagierten die Biomasse und der Stickstoffvorrat der Bodenvegetation mit einem Anstieg, wobei auch hinsichtlich dieser Größen die Kahlschlagflächen die höchsten Werte aufwiesen. Dies impliziert eine erhöhte Nährstoffverfügbarkeit und -aufnahme, insbesondere nach Kahlschlag, was durch die Entwicklung ausgewählter Pflanzenmerkmale, die eine schnelle Nährstoffaufnahme und Wachstumsrate kennzeichnen (eine hohe spezifische Blattfläche, eine krautige Wuchsform, das Auftreten von Arten stickstoffreicher Standorte) unterstützt wird. Das verstärkte Auftreten dieser funktionalen Merkmale scheint auch den Stickstoffverlust in Folge von Kahlschlag zu verringern. Doch bereits in den ersten fünf Jahren nach Kahlschlag zeigte die Vegetation eine Verschiebung von Arten, gekennzeichnet durch eine exzessive Nährstoffaufnahme, hin zu Arten, die häufig auf nährstoffarmen Böden zu finden sind und daher Nährstoffe effektiv speichern. Dies ist das Ergebnis einer Nährstoffverarmung des Bodens und des Pflanzengewebes aufgrund eines andauernden Pflanzenwachstums unter hoher Lichtverfügbarkeit. Die Reaktion der Vegetation nach Zielstärkennutzung war ähnlich der auf Kahlschlägen, doch von geringerem Ausmaß. Eine geringere Lichtverfügbarkeit und eine beständige Moosdeckung behinderten die Ausbreitung stickstoffliebender Arten, sowie von Baumarten. Die langsamere Reaktion der Bodenvegetation kann mit höheren anorganischen Stickstoffkonzentrationen im Sickerwasser verglichen zu Kontroll- und Kahlschlagflächen über den gesamten Untersuchungszeitraum in Verbindung gebracht werden. Die kürzer zurückliegende Kalkung eines Untersuchungsgebietes führte $\mathrm{zu}$ einer schnelleren Reaktion der Bodenvegetation hinsichtlich der Entwicklung relevanter Pflanzenmerkmale im Vergleich zum zweiten Gebiet. Die Kalkung erhöhte den Pool an, teilweise nitrophilen, Krautschicht-Arten, die sich unter den veränderten Umweltbedingungen schnell ausbreiten konnten. 
Eine letzte Studie untersuchte den potentiellen Einfluss der Bodensamenbank zu Beginn der Umwandlung von Fichtenreinbeständen. Die Bodensamenbank war vor allem eine Quelle für die Arten Carex pilulifera und Juncus effusus, die in der Lage sind eine langpersistente Samenbank aufzubauen. Sie spielte jedoch keine Rolle bei der Ausbreitung von Arten, die verjüngungshemmend wirken können (e.g. Calamagrostis epigejos, RubusArten). Der Aufbau einer persistenten Samenbank nach Störung, wie zu beobachten bei Rubus idaeus und $R$. fruticosus, kann jedoch bei einem wiederholten Störungsregime, wie es Zielstärkennutzung darstellt, zu Problemen führen. Eine frühe und erfolgreiche Integrierung von gewünschten Baumarten ist in diesem Falle wichtig um ihnen Wachstumsvorteile gegenüber den genannten Straucharten zu geben. Arten, die nur in geschlossenen Wäldern vorkommen wurden in der Samenbank kaum gefunden. Arten alter Waldstandorte, die für die natürlicherweise vorherrschenden bodensauren Buchenwälder charakteristisch sind, waren jedoch in größerer Zahl vorhanden und können zur zukünftigen Waldgesellschaft beitragen.

Zusammenfassend lässt sich feststellen, dass kleinflächige Kahlschläge im Solling keine weitreichenden negativen Auswirkungen auf die Diversität der Bodenvegetation, die Entwicklung der Verjüngung oder den Stickstoff-Kreislauf hatten im Vergleich zur Hiebsform der Zielstärkennutzung. Die Zusammensetzung der Bodenvegetation zu Beginn forstlicher Maßnahmen muss jedoch beachtet werden, da die Ausbreitung verjüngungshemmender Arten vorrangig vegetativ bedingt ist, während die Samenbank unter Fichtenaltbeständen nur eine geringe Rolle spielt. Kleinflächige Kahlschläge können daher eine sinnvolle Ergänzung zu Hiebsformen mit einer moderaten Störungsintensität sein und so die Ansiedlung einer diversen Verjüngung ermöglichen. Die Nutzung eines Mosaiks an Managementstrategien kann eine Struktur- und Artendiversität sowohl auf kleiner Fläche als auch auf Landschaftsebene fördern und zum Aufbau von Wäldern führen, die hinsichtlich des erwarteten Klimawandels anpassungsfähig sind. 


\title{
Chapter 1
}

\author{
Introduction
}

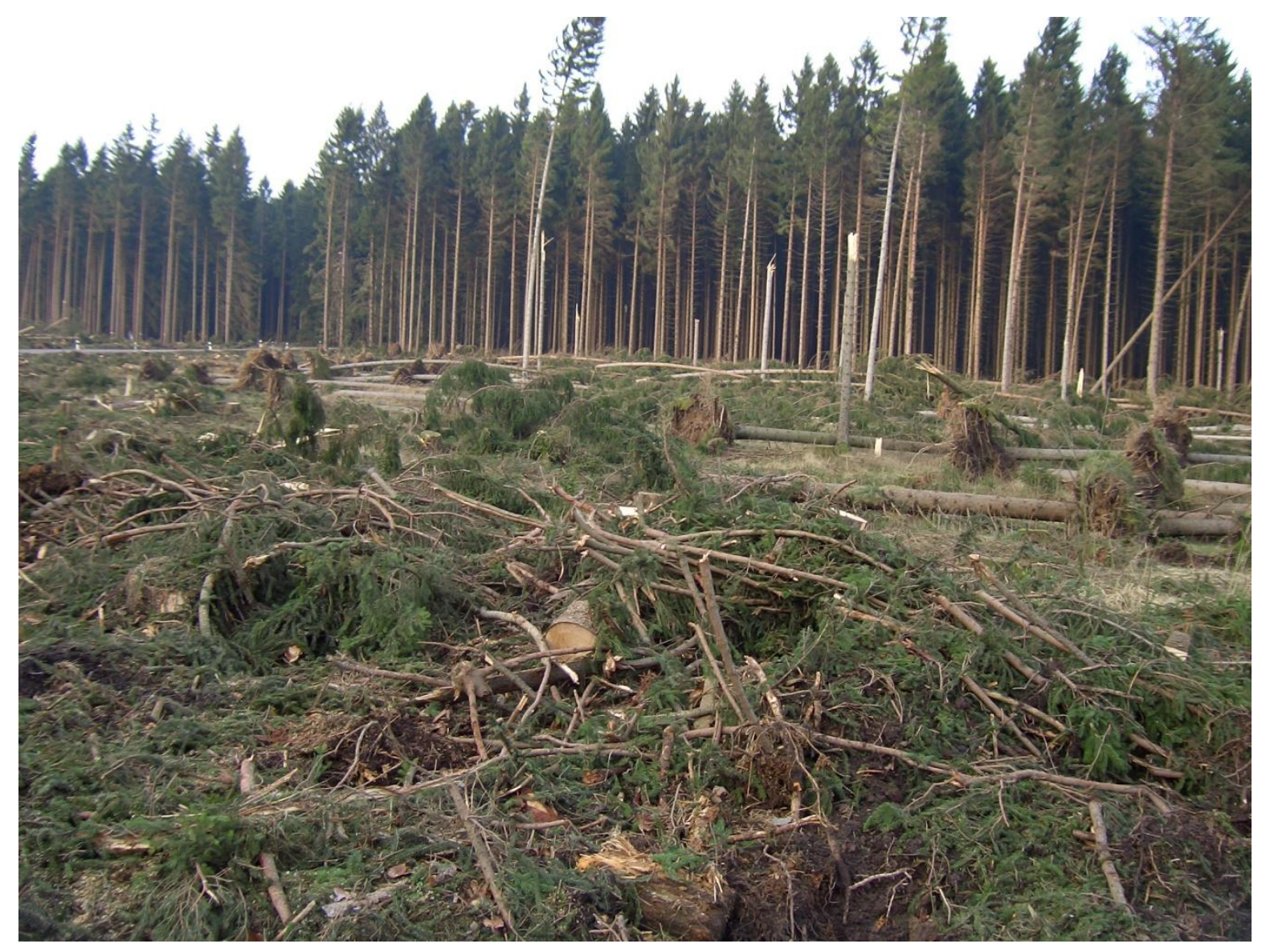


A Norway spruce forest in the Solling Hills after winter storm Kyrill on January $18^{\text {th }} 2007$. Photograph taken by Steffi Heinrichs (January 31 ${ }^{\text {st }}$ 2007). 


\section{General Introduction}

Though often not part of the natural vegetation, conifers, and in particular Norway spruce, were promoted in Central Europe due to economical, ecological, political and management constraints since the beginning of the $19^{\text {th }}$ century. Today 4 to 5 million ha of pure Norway spruce stands in Europe are situated on sites naturally dominated by broadleaved tree species, $31 \%$ of these forests are located in Germany (von Teuffel et al. 2004).

Doubts about planted monocultures were expressed very early, when problems of decreasing site quality and growth reduction with a second and third generation were discussed (e.g. Gayer 1889, Wiedemann 1925). With reaching maturity, the disadvantages of monoculture forest stands became even more obvious. Air pollution caused major forest dieback, for example in the Harz Mountains; severe storms swept over Germany and the rest of Europe and induced catastrophic damages in the last decades. Due to dry springs and summers, bark beetle attacks devastated spruce plantations (Lobinger 2004, NW-FVA 2007a). Such extreme events will pose the greatest threat to temperate forest ecosystems under the projected temperature increase in the future (Lindner et al. 2009), which in particular spruce monocultures on dry and temporally waterlogged sites would no longer be able to resist (Borchert \& Kölling 2004).

As such climate projections contain a large degree of uncertainty, the forest sector regards the maintenance of Norway spruce at most sites, but in combination with siteadapted broadleaved trees species as the best solution to produce productive and resilient forests. Pretzsch (2003) stated for example that mixed forests of spruce and beech are more flexible in the face of changes in site conditions and more resilient to natural disturbances than pure spruce stands. The same author also found an increase in productivity of beech and spruce mixtures compared to the according pure stands, however, dependent on site conditions (Pretzsch \& Schütze 2009). Risk spreading, a reduced intraspecific competition, and complementarity in resource use (e.g. uptake of water from different soil layers) are thought to determine a higher stability and productivity in such mixed stands. Moreover, broadleaved tree species within Norway spruce stands result in a greater total biomass of fine roots (Schmid 2002), in reduced nitrate leaching (Rothe 1997) and improve the litter quality (Albers et al. 2004; Brandtberg \& Lundkvist 2004) and the nutrient status of Norway spruce (Thelin et al. 2002) and its forest stands (Berger et al. 2009). In addition, Engel \& Ammer (2001) 
detected an increase in faunal diversity. Hence, the conversion of pure spruce stands into mixed stands is seen as the best option to enhance the resilience of forest ecosystems especially in light of the increasing importance of sustainability, not only regarding productivity but also in terms of biodiversity and sociological aspects; in short regarding a multifunctional forest ecosystem (UNCED 1992; MCPFE 1993, 1998).

In Germany, the conversion will mainly be conducted using target diameter harvesting regimes maintaining a continuous cover forest and achieving an uneven-aged forest structure (Haniel \& Kleinschmidt 1992; Sterba \& Zingg 2001). Clear cuts will be widely avoided; however, in some areas, very prone to windthrow, or on waterlogged soils, where spruce can only develop a shallow root system (Xu \& Fölster 1992), a faster conversion using strip cutting or even small scale clear cuttings might be necessary (Kenk \& Guehne 2001; von Lüpke et al. 2004). All conversion strategies will cause changes within the forest ecosystem in different magnitudes and will affect soil properties, water supply and biotic communities.

\section{Ecological importance of the understorey vegetation and its response to disturbance}

Though often disregarded, the understorey vegetation contributes largely to forest biodiversity and nutrient cycling. It is the initial competitor for the tree regeneration, and can by this means influence the development and composition of forest stands (Gilliam 2007). Depending on its severity and spatial extent, disturbances such as single or total tree harvesting can have severe effects on these functions:

\section{Forest biodiversity}

Herbaceous species account for about 80 \% of vascular plant species in Central Europe, whilst trees make up only $2 \%$ of total species numbers (Ellenberg 1996). This is also reflected in forest ecosystems (Hermy et al. 1999; Whigham 2004). Beside this direct contribution to biodiversity, the herbaceous layer shows strong feedbacks with other trophic levels (e.g. Hunter \& Price 1992; Schaefer 2004).

Often stress tolerant species characterise the understorey of closed forests, which have adapted to the low light availability (Hermy et al. 1999; Grime 2001). They are negatively affected by thinning or a total removal of the overstorey (Godefroid et al. 2005), and show a decrease in abundance or are out-competed by others. In spruce forests also the moss layer is very abundant and divers (Ellenberg 1996). Beside 
influences of microclimate changes, the moss layer is particularly affected by mechanical disturbance during forest management (Kellomäki \& Saastamoinen 1975). However, mosses show a variety of regeneration methods and are thought to regenerate fast (Jonsson \& Esseen 1998; Caners et al. 2009), whereas the risk of extirpation is high for woodland herbs. Due to a high seed weight (in general $>2 \mathrm{mg}$ ), forest specialists i.e. species predominantly growing in closed forests, have a low reproductive output and a limited, only short-distance dispersal capacity (Brunet \& von Oheimb 1998; Ehrlén \& Eriksson 2000; Whigham 2004). Recruitment limitations over the whole life cycle as detected by Baeten et al. (2009) add up to this. In addition, seed size is negatively correlated with seed longevity, reducing the probability of regeneration from the soil seed bank (Bekker et al. 1998). Consequently, vegetative persistence after severe disturbance is crucial for sensitive species to remain within forest stands.

Other often light-demanding non-forest species, on the contrary, benefit from soil and canopy disturbance, when site heterogeneity increases and temporary invasion windows are created (Huston 1994). In particular, species with wind dispersed or longlived seeds persisting in the soil seed bank can colonize these windows and contribute to species diversity. When reaching dominance, though, single species can also diminish diversity by out-competing others (Hannerz \& Hånell 1997).

There is also evidence that changes in species diversity and composition can alter ecosystem processes including biomass production and nitrogen cycling (Hooper et al. 2005; Cardinale et al. 2007; see further below); thereby mainly the identity of species or functional groups is essential rather than species or functional group richness per se (Hooper \& Vitousek 1998; Knops et al. 2002).

\section{Competition for tree regeneration}

The ability to reach dominance early after disturbance holds especially for those species being present in the intact forest and surviving disturbance with vegetative organs. According to Bormann \& Likens (1994), this applies to the majority of species participating in the early revegetation after disturbance. In Norway spruce forests species such as Rubus fruticosus, R. idaeus, Calamagrostis epigejos or Deschampsia flexuosa have to be mentioned (Rodenkirchen 1991; Zerbe 1993; Weckesser 2003), known to be successful in early succession (Prach \& Pysek 1999). With their initial presence and expansion, they can inhibit the establishment of later arriving tree species, and thus, decelerate the development of a forest stand (Glenn-Lewin 1980; George \& 
Bazzaz 2003). This would comply with the "inhibition model" presented by Connell \& Slatyer (1977), where early colonists exclude or suppress all other species.

A dense understorey vegetation cover also offers living space and attracts seed, root and bark eating rodents (Fig. 1; Wasem \& Häne 2006; Huitu et al. 2009).

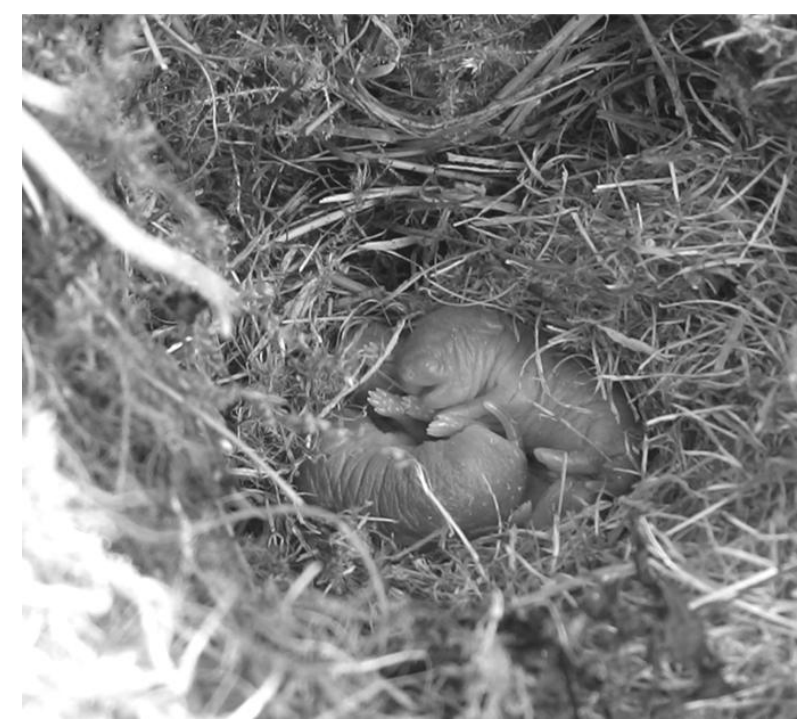

Fig. 1: Mouse nest with offspring within dense grass litter on clear cuts (Photo: S. Heinrichs).

These rodents favour in particular seedlings of deciduous tree species (including Fagus sylvatica and Acer pseudoplatanus), an aggravating factor for the intended propagation of mixed forests (NW-FVA 2007b).

Next to these indirect negative effects of a dense understorey, especially tall growing species can directly impede the growth of planted or natural established tree regeneration by limiting light and/or nutrient resources (Fig. 2; Brünn 1999; Mitchell et al. 1999; Wetzel \& Burgess 2001; Balandier et al. 2006).

\section{Nutrient cycling}

However, a shift in species composition including the expansion of competitive species after disturbance is also an important ecosystem strategy to regain a full biotic regulation after disturbance and diminish nutrient losses with seepage water and erosion (Bormann \& Likens 1994; Brünn 1999). Following disturbance, nitrification and mineralisation are enhanced (Bormann \& Likens 1994) leading to a decrease in soil organic matter and to nutrient release. In particular species with an excessive nutrient uptake and high nutrient concentrations in their tissue can exploit these conditions and be effective in mitigating nutrient losses; even more important is the overall increase in 


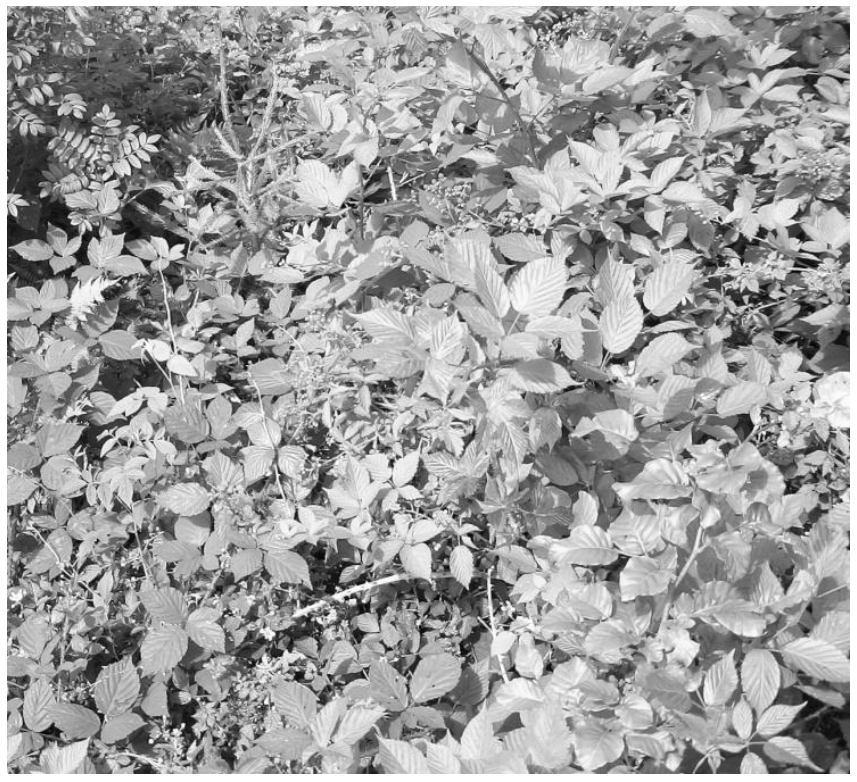

Fig. 2: Beech regeneration (bottom right) within Rubus fruticosus on clear cuts (Photo: S. Heinrichs)

total understorey biomass that was found to correlate negatively with nutrient concentrations in the seepage water (Mellert et al. 1998; Bartsch 2000). Consequently, species contributing most to biomass production determine ecosystem properties (Grime 1998). When vegetation development was suppressed, nitrate losses were about 40 times higher than detected under an undisturbed forest at the Hubbard Brook Experimental site (Likens et al. 1970). On the contrary, Weis et al. (2001) found no effect of tree removal on nitrate concentration in the seepage water at spots with dense vegetation cover.

Moreover, at least the foliage of most herb layer species is short-lived and decomposes more than twice as fast as tree litter. In combination with high nutrient concentrations in the herb layer foliage, this high turnover rate facilitates efficient recycling of nutrients and contributes to site productivity (Muller 2003). Thereby the understorey on baserich soils seems often more effective in nutrient retention than on acidic soils (Mrotzek 1998), not only following disturbance, but also in the spring before deciduous canopy development (Eggert 1985; Tessier \& Raynal 2003).

\section{Aims and outline of this thesis}

Summarizing the above mentioned, the initial response of the understorey to disturbance can be crucial for further forest stand development and can facilitate or conflict the goal of Norway spruce conversion. Thereby, the severity of disturbance is important, with clear cutting and single tree selection cutting representing two opposing management strategies. Especially clear cutting is expected to have many negative effects on the forest ecosystem in terms of late-successional species diversity (e.g. 
Hannerz \& Hånell 1997; Godefroid et al. 2005), competiton for tree regeneration (e.g. Nilsson \& Örlander 1999) and nutrient losses (Stevens et al. 1995; Högbom et al. 2002), whilst effects after selection cutting are expected to be very moderate (e.g. Collins \& Pickett 1987; Von Oheimb \& Härdtle 2009) as this treatment is considered 'close-tonature'. Direct comparisons including all those aspects especially in the context of Norway spruce stand transformation are, however, scarce.

Hence, the present study examines the response of the understorey vegetation in relation to temporal and spatial references during the initial phase of Norway spruce conversion using either selection cutting or small scale clear cutting. Thereby the main objectives presented in the upcoming Chapters 3 to 5 of this thesis are:

(1) to determine the response of the shrub and herb layer in terms of species diversity and composition by simultaneously regarding the development of relevant functional species groups (ecological strategy, habitat preference and life form) after selection cutting and clear cutting (Chapter 3)

(2) to evaluate the response of aboveground biomass and nitrogen pools of the understorey with special emphasis on resource use indicators (specific leaf area, woodiness, proportion of evergreens, growth form, nitrogen indicators) to both forest management regimes and linking results to the nitrogen cycle (Chapter 4.2). Biomass and nitrogen pools were calculated based on an existing estimation model calibrated for forest conditions. Under full light conditions on clear cuts though, this model had to be adjusted for herbaceous plants and small shrubs (Chapter 4.1) and for tree regeneration species (Chapter 4.2).

(3) to determine the effect of the soil seed bank on vegetation development after selection cutting and clear cutting by considering its potential to constrain or facilitate conversion. This depends on the amount of competitive strategists and late-successional forest species within the soil seed bank (Chapter 5).

A long-term Before/After-Control/Impact-experiment (BACI; Bennett \& Adams 2004), established by the Northwest German Forest Research Station in 2002 at two sites in the Solling Hills, provided the basis for studying these objectives. A detailed description of the study area and the experimental sites is given in Chapter 2. 
In Chapter 6, the results of the previous chapters are merged and discussed in order to assess the appropriateness of both management regimes for Norway spruce conversion and to give implications for forest management in the future.

\section{Declaration of the author's own contribution to manuscripts with multiple authors}

The Chapters 3 to 5 represent a series of manuscripts that are already published, or will be submitted to peer-reviewed journals.

Steffi Heinrichs is the overall author of all manuscripts presented in this thesis. She has personally developed the main ideas presented in the manuscripts, has written all manuscripts, analysed all the data, created all figures and tables, and is responsible for the communication with editors and reviewers. She collected all data from 2006 onwards.

Format differences regarding abstract-structure, keywords and citations are based on the guidelines of the journals the manuscripts were or will be submitted to. These guidelines were retained in the course of writing this thesis.

\section{References}

Albers, D., Migge, S., Schaefer, M., Scheu, S. 2004. Decomposition of beech leaves (Fagus sylvatica) and spruce needles (Picea abies) in pure and mixed stands of beech and spruce. Soil Biology \& Biochemistry 36: 155-164.

Baeten, L., Jacquemyn, H., Van Calster, H., Van Beek, E., Devlaeminck, R., Verheyen, K., Hermy, M. 2009. Low recruitment across life stages partly accounts for the slow colonization of forest herbs. Journal of Ecology 97: 109-117.

Balandier, P., Collet, C., Miller, J.H., Reynolds, P.E., Zedaker, S.M. 2006. Designing forest vegetation management strategies based on the mechanisms and dynamics of crop tree competition by neighbouring vegetation. Forestry 79: 3-27.

Bartsch, N. 2000. Element release in beech (Fagus sylvatia L.) forest gaps. Water, Air, and Soil Pollution 122: 3-16.

Bekker, R.M., Bakker, J.P., Grandin, U., Kalamees, R., Milberg, P., Poschlod, P., Thompson, K., Willems, J.H. 1998. Seed size, shape and vertical distribution in the soil: indicators of seed longevity. Functional Ecology 12: 834-842.

Bennett, M.A., Adams, M.A. 2004. Assessment of ecological effects due to forest harvesting: approaches and statistical issues. Journal of Applied Ecology 41: 585-598. 
Berger, T.W., Untersteiner, H., Toplitzer, M., Neubauer, C. 2009. Nutrient fluxes in pure and mixed stands of spruce (Picea abies) and beech (Fagus sylvatica). Plant and Soil 322: 317-342.

Borchert, H., Kölling, C. 2004. Waldbauliche Anpassung der Wälder an den Klimawandel jetzt beginnen. LWF aktuell 43: 28-30.

Bormann, F.H., Likens, G.E. 1994. Pattern and process in a forested ecosystem. Springer, New York.

Brandtberg, P.-O., Lundkvist, H. 2004. Does an admixture of Betula species in Picea abies stands increase organic matter quality and nitrogen release? Scandinavian Journal of Forest Research 19: 127-141.

Brunet, J., von Oheimb, G. 1998. Migration of vascular plants to secondary woodlands in southern Sweden. Journal of Ecology 86: 429-438.

Brünn, S. 1999. Untersuchungen zum Mineralstoffhaushalt von Calamagrostis epigejos (L.) Roth in stickstoffbelasteten Kiefernwäldern. Berichte des Forschungszentrums Waldökosysteme A160: 1-163.

Caners, R.T., Macdonald, S.E., Belland, R.J. 2009. Recolonization potential of bryophyte diaspore banks in harvested boreal mixed-wood forest. Plant Ecology 204: 55-68.

Cardinale, B.J., Wright, J.P., Cadotte, M.W., Carroll, I.T., Hector, A., Srivastava, S.S., Loreau, M., Weis, J.J. 2007. Impacts of plant diversity on biomass production increase through time because of species complementarity. Proceedings of the National Academy of Sciences 104: 18123-18128.

Collins, B.S., Pickett, S.T.A. 1987. Influence of canopy opening on the environment and herb layer in a northern hardwoods forest. Vegetatio 70: 3-10.

Connell, J.H., Slatyer, R.O. 1977. Mechanisms of succession in natural communities and their role in community stability and organization. The American Naturalist 111: 1119-1144.

Eggert, A. 1985. Zur Ökologie der Krautschichtvegetation in einem BärlauchKalkbuchenwald. Dissertation der Georg-August-Universität Göttingen.

Ehrlén, J., Eriksson, 0. 2000. Dispersal limitation and patch occupancy in forest herbs. Ecology 81: 1667-1674.

Ellenberg, H. 1996. Vegetation Mitteleuropas mit den Alpen. 5. Auflage, Ulmer Verlag, Stuttgart. 
Engel, K., Ammer, U. 2001. Analyse und Bewertung von Umbaumaßnahmen in Fichtenreinbeständen anhand ökologischer Gilden der Wirbellosen-Fauna. Forstwissenschaftliches Centralblatt 120: 242-255.

Gayer, K. 1889. Der Waldbau. 3. Auflage, Parey Verlag, Berlin.

George, L.O., Bazzaz, F.A. 2003. The herbaceous layer as a filter determining spatial pattern in forest tree regeneration. In: Gilliam, F.S., Roberts, M.R. (eds). The Herbaceous Layer in Forests of Eastern North America, Oxford University Press, New York, pp. 265-282.

Gilliam, F.S. 2007. The ecological significance of the herbaceous layer in temperate forest ecosystems. Bioscience 57: 845-858.

Glenn-Lewin, D.C. 1980. The individualistic nature of plant community development. Vegetatio 43: 141-146.

Godefroid, S., Rucquoij, S., Koedam, N. 2005. To what extent do forest herbs recover after clearcutting in beech forests? Forest Ecology and Management 210: 39-53.

Grime, J.P. 1998. Benefits of plant diversity to ecosystems: immediate, filter and founder effects. Journal of Ecology 86: 902-910.

Grime, J.P. 2001. Plant strategies, vegetation processes, and ecosystem properties. $2^{\text {nd }}$ edition, Wiley \& Sons, Chichester, UK.

Haniel, J., Kleinschmidt, H. 1992. Zielstärkennutzung in den niedersächsischen Landesforsten. Allgemeine Forstzeitung 47: 588-593.

Hannerz, M., Hånell, B. 1997. Effects on the flora in Norway spruce forests following clearcutting and shelterwood cutting. Forest Ecology and Management 90: 29-49.

Hermy, M., Honnay, O., Firbank, L., Grashof-Bokdam, C., Lawesson, J.E. 1999. An ecological comparison between ancient and other forest plant species of Europe, and the implications for forest conservation. Biological Conservation 91: 9-22.

Högbom, L., Nilsson, U., Örlander, G. 2002. Nitrate dynamics after clear felling monitored by in vivo nitrate reductase acticity (NRA) and natural ${ }^{15} \mathrm{~N}$ abundance of Deschampsia flexuosa (L.) Trin. Forest Ecology and Management 160: 273-280.

Hooper, D.U., Vitousek, P.M. 1998. Effects of plant composition and diversity on nutrient cycling. Ecological Monographs 68: 121-149.

Hooper, D.U., Chapin III, F.S., Ewel, J.J., Hector, A., Inchausti, P., Lavorel, S., Lawton, J.H., Lodge, D.M., Loreau, M., Schmid, B., Setälä, H., Symstad, A.J., Vandermeer, J., Wardle, D.A. 2005. Effects of biodiversity on ecosystem functioning: a consensus of current knowledge. Ecological Monographs 75: 3-35. 
Huitu, O., Kiljunen, N., Korpimäki, E., Koskela, E., Mappes, T., Pietiäinen, H., Pöysä, H., Henttonen, H. 2009. Density-dependent vole damage in silviculture and associated economic losses at a nationwide scale. Forest Ecology and Management 258: 12191224.

Hunter, M.D., Price, P.W. 1992. Playing chutes and ladders: Heterogeneity and the relative roles of bottom-up and top-down forces in natural communities. Ecology 73 : 724-732.

Huston, M.A. 1994. Biological diversity: the coexistence of species on changing landscapes. University Press, Cambridge.

Jonsson, B.G., Esseen, P.-A. 1998. Plant colonisation in small forest-floor patches: importance of plant group and disturbance traits. Ecography 21: 518-526.

Kenk, G., Guehne, S. 2001. Management of transformation in central Europe. Forest Ecology and Management 151: 107-119.

Kellomäki, S., Saastamoinen, V.L. 1975. Trampling tolerance of forest vegetation. Acta Forestalia Fennica 147: 1-21.

Knops, J.M.H., Bradley, K.L., Wedin, D.A. 2002. Mechanisms of plant species impacts on ecosystem nitrogen cycling. Ecology Letters 5: 454-466.

Likens, G.E., Bormann, F.H., Johnson, N.M., Fisher, D.W., Pierce, R.S. 1970. Effects of forest cutting and herbicide treatment on nutrient budgets in the Hubbard Brook Watershed-Ecosystem. Ecological Monographs 40: 23-47.

Lindner, M., Maroschek, M., Netherer, S., Kremer, A., Barbati, A., Garcia-Gonzalo, J., Seidl, R., Delzon, S., Corona, P., Kolström, M., Lexer, M.J., Marchetti, M. 2009. Climate change impacts, adaptive capacity, and vulnerability of European forest ecosystems. Forest Ecology and Management doi: 10.1016/j.foreco.2009.09.023.

Lobinger, G. 2004. Der „Käfersommer“ 2003 - Ein Rückblick auf das Befallsgeschehen. LWF aktuell 43: 26-27.

MCPFE (Ministerial Conference on the Protection of Forests in Europe) 1993. Helsinki 1993 - A commitment to sustainable forest management in Europe. Internetdocument (24.11.09). URL: http://www.mcpfe.org/eng/Commitments/Ministerial_ Conferences/Helsinki_1993/.

MCPFE (Ministerial Conference on the Protection of Forests in Europe) 1998. Lisbon 1998 - Recognising the multiple roles of forests. Internet-document (24.11.09). URL: http://www.mcpfe.org/eng/Commitments/Ministerial_Conferences/Lisbon_ $1998 /$. 
Mellert, K.H., Kölling, C., Rehfuess, K.E. 1998. Vegetationsentwicklung und Nitrataustrag auf 13 Sturmkahlflächen in Bayern. Forstarchiv 69: 3-11.

Mitchell, R.J., Zutter, B.R., Gjerstad, D.H., Glover, G.R., Wood, C.W. 1999. Competition among secondary-successional pine communities: a field study of effects and responses. Ecology 80: 857-872.

Mrotzek, R. 1998. Wuchsdynamik und Mineralstoffhaushalt der Krautschicht in einem Buchenwald auf Basalt. Berichte des Forschungszentrums Waldökosysteme A152: 1197.

Muller, R.N. 2003. Nutrient relations of the herbaceous layer in deciduous forest ecosystems. In: Gillian, F.S., Roberst, M.R. (eds). The herbaceous layer in forests of eastern North America. Oxford University Press, New York, pp. 15-37.

Nilsson, U., Örlander, G. 1999. Vegetation management on grass-dominated clearcuts planted with Norway spruce in southern Sweden. Canadian Journal of Forest Research 29: 1015-1026.

NW-FVA (Nordwestdeutsche Forstliche Versuchsanstalt) 2007a. Waldschutzinformation 01/2007 - Sturmholz und Borkenkäfer. Abteilung Waldschutz.

NW-FVA (Nordwestdeutsche Forstliche Versuchsanstalt) 2007b. Praxis-Information: Mäuse in forstlichen Verjüngungen - Arten, Schäden, Prognose, Bekämpfung. Abteilung Waldschutz.

Prach, K., Pyšek, P. 1999. How do species dominating in succession differ from others? Journal of Vegetation Science 10: 383-392.

Pretzsch, H. 2003. Diversität und Produktivität von Wäldern. Allgemeine Forst- und Jagdzeitung 174: 88-98.

Pretzsch, H., Schütze, G. 2009. Transgressive overyielding in mixed compared with pure stands of Norway spruce and European beech in Central Europe: evidence on stand level and explanation on individual tree level. European Journal of Forest Research 128: $183-204$.

Rodenkirchen, H. 1991. Entwicklung der Waldbodenvegetation auf den Versuchsflächen des Höglwald-Experiments im Beobachtungszeitraum 1983-1989. Forstwissenschaftliche Forschung 39: 74-86.

Rothe, A. 1997. Einfluss des Baumartenanteils auf Durchwurzelung, Wasserhaushalt, Stoffhaushalt und Zuwachsleistung eines Fichten-Buchen-Mischbestandes am Standort Höglwald. Forstliche Forschungsberichte München 163: 1-174. 
Schaefer, M. 2004. Lebensräume und Lebensgemeinschaften in Mischwäldern im Vergleich zu monospezifischen Wäldern (Biodiversität) - Diversität der Bodenfauna. Berichte des Forschungszentrums Waldökosysteme B71: 133-170.

Schmid, I. 2002. The influence of soil type and interspecific competition on the fine root system of Norway spruce and European beech. Basic and Applied Ecology 3: 339346.

Sterba, H., Zingg, A. 2001. Target diameter harvesting - a strategy to convert even-aged forests. Forest Ecology and Management 151: 95-105.

Stevens, P.A., Norris, D.A., Williams, T.G., Hughes, S., Durrant, D.W.H., Anderson, M.A., Weatherley, N.S., Hornung, M., Woods, C. 1995. Nutrient losses after clearfelling in Beddgelert Forest: a comparison of the effects of conventional and whole-tree harvest on soil water chemistry. Forestry 68: 115-131.

Tessier, J.T., Raynal, D.J. 2003. Vernal nitrogen and phosphorus retention by forest understorey vegetation and soil microbes. Plant and Soil 256: 443-453.

Thelin, G., Rosengren, U., Callesen, I., Ingerslev, M. 2002. The nutrient status of Norway spruce in pure and in mixed-species stands. Forest Ecology and Management 160: 115-125.

UNCED (United Nations Conference on Environment and Development) 1992. Internetdocument (24.11.09). URL: http://www.un.org/geninfo/bp/enviro.

Von Lüpke, B., Ammer, C., Bruciamacchie, M., Brunner, A., Ceitel, J., Collet, C., Deuleuze, C., Di Placido, J., Huss, J., Jankovič, Kantor, P., Larsen, J.B., Lexer, M., Löf, M., Longauer, R., Madsen, P., Modrzyński, J., Mosandl, R., Pampe, A., Pommerening, A., Štefančik, I., Tesař, V., Thompson, R., Zientarski, J. 2004. Silvicultural Strategies for Conversion. In: Spiecker, H., Hansen, J., Klimo, E., Skovsgaard, J.P., Sterba, H., von Teuffel, K. (eds). Norway Spruce Conversion - Options and Consequences. European Forest Institute Research Report 18: 121-164.

Von Oheimb, G., Härdtle, W. 2009. Selection harvest in temperate deciduous forests: impact on herb layer richness and composition. Biodiversity and Conservation 18: 271-287.

Von Teuffel, K., Heinrich, B., Baumgarten, M. 2004. Present Distribution of Secondary Norway Spruce in Europe. In: Spiecker, H., Hansen, J., Klimo, E., Skovsgaard, J.P., Sterba, H., von Teuffel, K. (eds). Norway Spruce Conversion - Options and Consequences. European Forest Institute Research Report 18: 63-96. 
Wasem, U., Häne, K. 2006. Natürlich verjüngte Stieleichen - Einflüsse von Mäusen, Rehen und Brombeeren. Wald und Holz 3: 49-51.

Weckesser, M. 2003. Die Bodenvegetation von Buchen-Fichten-Mischbeständen im Solling - Struktur, Diversität und Stoffhaushalt. Cuvillier, Göttingen.

Weis, W., Huber, C., Göttlein, A. 2001. Regeneration of mature Norway spruce stands: early effects of selective cutting and clear cutting on seepage water quality and soil fertility. The Scientific World 1, Supplement 2: 493-499.

Wetzel, S., Burgess, D. 2001. Understorey environment and vegetation response after partial cutting and site preparation in Pinus strobus L. stands. Forest Ecology and Management 151: 43-59.

Whigham, D.F. 2004. Ecology of woodland herbs in temperate deciduous forests. Annual Review of Ecology, Evolution and Systematics 35: 583-621.

Wiedemann, E. 1925. Zuwachsrückgang und Wuchsstockungen der Fichte in den mittleren und unteren Höhenlagen der sächsischen Staatsforsten. 2. Auflage, Akademische Buchhandlung Walter Laux, Tharandt.

Xu, Y., Fölster, H. 1992. Vergleichende Untersuchung über Durchwurzelungstiefe und Wurzelverteilung von Küstentanne und Fichte auf pseudovergleyten Böden. Forst und Holz 47: 560-565.

Zerbe, S. 1993. Fichtenforste als Ersatzgesellschaften von Hainsimsen-Buchenwäldern. Berichte des Forschungszentrums Waldökosysteme A100: 1-173. 


\section{Chapter 2}

The study area

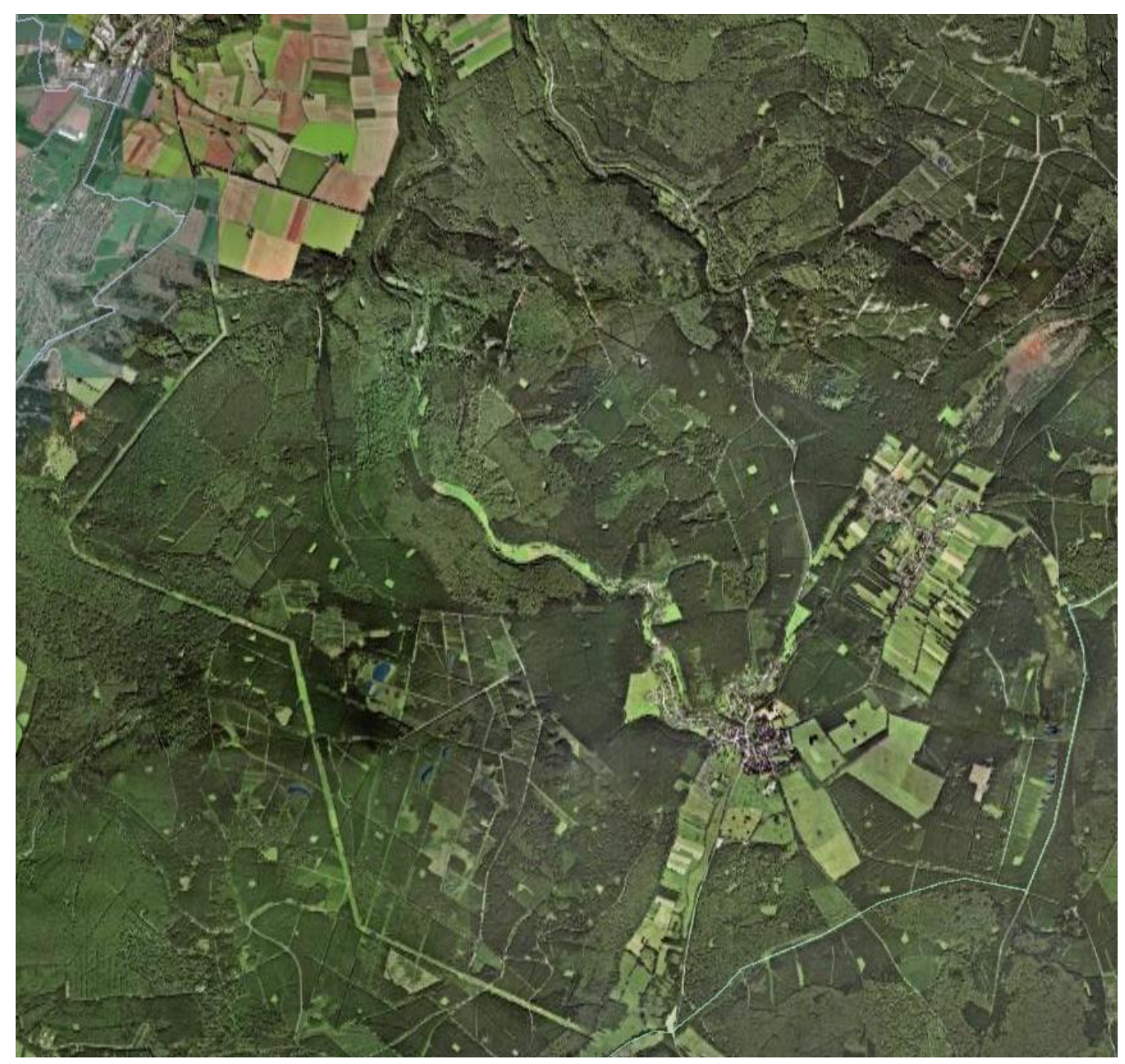


Aerial picture of the study area around the village Neuhaus im Solling (close to the pictures centre). Source: Google Earth (2009), Version 5.0.1. 


\section{Natural conditions}

The study was conducted in the Solling Hills, a low mountain range in Lower Saxony, Germany, about $80 \mathrm{~km}$ south of Hannover and $30 \mathrm{~km}$ northwest of Göttingen. As part of the Weser Hills and the natural geographic region "Mitteldeutsches Trias-Berg- und Hügelland", it is the result of tectonic processes in the tertiary uplifting a massive of Triassic sandstone, which forms the prevalent geological substrate of the Solling. Only in the outskirts also Muschelkalk and Keuper occur (NMELF 1996). The whole area is covered with 60 to $80 \mathrm{~cm}$ thick solifluction layers of loess material. These basic conditions caused the development of brown soils with different amounts of silt and loam, different degrees of podsolization (Dystric Cambisol according to the FAO classifiation), and mor to moder humus forms (Ellenberg et al. 1986). The base saturation can be classified as moderate to low according to Gauer \& Aldinger (2005). Meesenburg et al. (2009) mention numbers below $7 \%$ for beech stands in the Solling area, whereas Weckesser (2003) found a mean base saturation of $34 \%$ for mature spruce forests in the study area as a result of amelioration liming.

Along the climatic altitudinal zones, the Solling is further separated in two sub-regions: The Lower Solling (250-400 $\mathrm{m}$ above sea level) exhibits a rather colin climate, whilst the Upper Solling (400-528 $\mathrm{m}$ above sea level) is characterised by a submontane to montane climate (Table 1). Due to the high precipitation, impermeability of lower soil layers and the predominance of plateaus, soils in the Upper Solling often face waterlogging and show transitions to pseudogleys (Stagnosol according to the FAO classification; NMELF 1996).

Table 1 Temperature and precipitation values for the two Solling subregions according to Gauer \& Aldinger (2005).

\begin{tabular}{lrr}
\hline & Lower Solling & Upper Solling \\
\hline Mean annual temperature $\left[{ }^{\circ} \mathrm{C}\right]$ & 7.8 & 7.3 \\
Mean temperature - May to September $\left[{ }^{\circ} \mathrm{C}\right]$ & 14.0 & 13.3 \\
Mean annual precipitation $[\mathrm{mm}]$ & 915 & 1029 \\
Mean precipitation - May to September $[\mathrm{mm}]$ & 395 & 438 \\
\hline
\end{tabular}

Climatic conditions favour in general deciduous forests. Acidic species poor beech forests (Luzulo-Fagetum) represent the natural vegetation on most Solling soils with transitions to Galio-Fagetum on more base rich sites (Gerlach 1970). Today, the artificially introduced Norway spruce is the dominant tree species (Table 2). 
Table 2 Total and forest area of the Solling subregions and the contribution of tree species according to Gauer \& Aldinger (2005).

\begin{tabular}{lrr}
\hline & Lower Solling & Upper Solling \\
\hline Total area [ha] & 46717 & 9642 \\
Forest area [ha] & 30784 & 9030 \\
Share of European beech in forest area [\%] & 24 & 30 \\
Share of Norway spruce in forest area [\%] & 57 & 62 \\
\hline
\end{tabular}

For the present study, two study sites were chosen representing the Solling subregions. The site Otterbach is situated in the Lower Solling at 270 to $300 \mathrm{~m}$ altitude. The site Neuhaus on the Moosberg was chosen for the Upper Solling at $500 \mathrm{~m}$ altitude. Both sites differ slightly in their forest history.

\section{Forest history of the Solling sites}

For thousands of years the whole Solling-landscape was shaped by forests, with beech forests being predominant since the Subatlantic (ca. 800 BC). Only on very moist sites in the Upper Solling birch swamps or open moorland as azonal vegetation types could prevail (Gerlach 1970).

As soils over triassic standstone were unapt for early land cultivation and mineral resources were rare, human settlements were not traceable until the year 800 . In the $11^{\text {th }}$ and $12^{\text {th }}$ century the anthropogenic influence on the Solling forests, by forest grazing and deforestation, increased for a short period but only at lower elevations (for example around the site Otterbach). As recently as the $15^{\text {th }}$ century, major changes occurred in the whole study area. The forests were changed and exploited in a multilateral kind. They were used for wood production (fire and construction wood) and for glass- and ironworks as well as for forest grazing and litter raking. Thereby, oak was promoted in lower altitudes based on its importance for feeding of domestic animals and house construction. Consequently, oak forests grew on the Otterbach site around 1600. At the same time unforested heathland used for grazing marked the Moosberg (NMELF 1996).

With the separation of forest and pasture management in the $19^{\text {th }}$ century (mainly 1850 to 1885) a transition to high forest management occured. Afforestation of the many depleted and unforested areas like the study site Neuhaus was conducted using the regional non-native Norway spruce that was first detected 1728 in the Solling. This species could be, in contrast to beech, established successfully under open site 
conditions. Later, also existing deciduous forests (in Otterbach oak forests with a beech coppice as underplant) were converted into spruce forests to increase productivity (NMELF 1996). Large reparation cuttings after the Second World War undid efforts to invert this trend and even increased the area planted with spruce.

A key turning point was a catastrophic storm event in 1972 that spotlighted the importance of forest stability. The promotion of mixed species stands with a large proportion of deciduous tree species started and is since 1991 implemented in the federal state governmental program (LÖWE - Langfristige Ökologische Waldentwicklung in den Landesforsten) of Lower Saxony (Niedersächsische Landesregierung 1991). The programs objectives are among others the propagation of broadleaved and mixed stands, the use of natural regeneration and site adapted tree species, the use of target diameter harvesting and the protection of endangered plant and animal species. In 2007 current political requirements such as the EU Habitats Directive (Natura 2000) were additionally included (NMELV 2007). At the two Solling sites mainly the establishment of mixed species stands using Norway spruce, European beech, Douglas fir and naturally regenerating sycamore is aspired. In moist plateau areas pioneer tree species (e.g. Populus tremula, Sorbus aucuparia) within spruce-beechmixed stands should be promoted as stabilizing elements (NMELV 2004)

\section{Experimental sites}

At both mentioned study sites six 1 ha plots were established in 2002 in 84-year-old (Otterbach) and 89- and 103-year-old (Neuhaus) Norway spruce stands. Two plots were treated with target diameter harvesting, where in general single trees with a dbh $\geq 45$ $\mathrm{cm}$ are removed (in the following referred to as selection cutting treatment), two with clear cutting and two were left unmanaged in autumn of 2003 (see Fig. 1 for the design of the study site Otterbach). Selection cutting resulted in a $7 \%$ (Otterbach) and $10 \%$ (Neuhaus) reduction in canopy cover, and in a $24 \%$ (Otterbach) and $28 \%$ (Neuhau) reduction of basal area. Logging residues were removed and piled on 5 to $10 \mathrm{~m}$ wide skidding tracks.

The plots were divided into $20 \times 400-\mathrm{m}^{2}$-subplots. On all but four subplots on clear cutting and selection cutting plots the natural spruce regeneration was removed and beech (in two densities) and Douglas fir saplings were planted group wise. At Neuhaus, plots treated with strip cutting were as well established but were not regarded within 
the scope of this study. To protect the planted saplings from deer browsing, the plots were fenced.

Vegetation surveys were conducted in the $100-\mathrm{m}^{2}$-center of all subplots before treatment in the summer 2002 and after treatment in the summer seasons 2004, 2006 and 2007. In 2005 and 2008 only the vegetation on plots with natural spruce regeneration was mapped. The surveys formed the basis of most of the analyses presented in Chapters 3 through 5. A detailed description of used methods is provided in the single chapters.

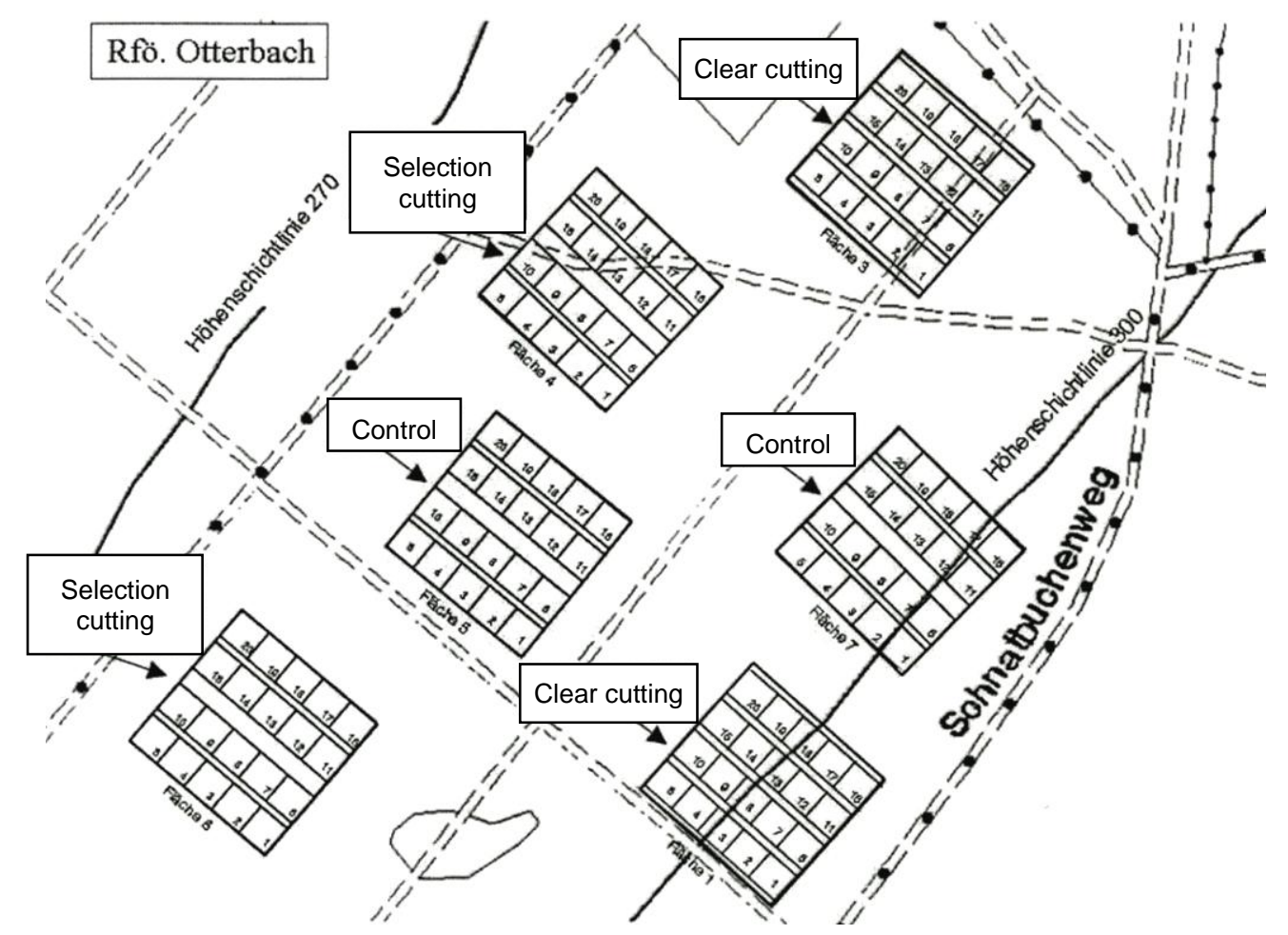

Fig. 1: Experimental design at the study site Otterbach with two plots treated with clear cutting, two with selection cutting and two left unmanaged (Control). The figure also shows the contour lines at 270 and $300 \mathrm{~m}$.

The higher stand age at the site Neuhaus was probably responsible for a lower canopy cover compared to Otterbach (60 \% vs. $65 \%$ ). In addition, soils at the Neuhaus site were ameliorated with 3 t/ha of dolomitic lime more recently (2001 in Neuhaus vs. about 1990 in Otterbach). These distinct site conditions were responsible for some differences in species composition before treatment and for differences in vegetation development after treatment. This will be discussed in the upcoming chapters and particularly in Chapter 6. However, before treatment, the spruce stands at both study sites could in general be assigned to the vegetation community Galio-Culto-Piceetum oxalidetosum with transitions to the molinietosum subassociation in Neuhaus (Zerbe 1993). Common 
species of the herbaceous layer were for example Carex pilulifera, Oxalis acetosella, Dryopteris dilatata, Deschampsia flexuosa and Vaccinium myrtillus. The moss layer was dominated by Polytrichum formosum, Hypnum cupressiforme or Plagiothecium curvifolium. Saplings were frequently detected, but comprised in general only the species Picea abies, S. aucuparia, Frangula alnus, Acer pseudoplatanus or Fagus sylvatica. The most frequent woody species were Rubus fruticosus and R. idaeus.

\section{References}

Ellenberg, H., Mayer, R., Schauermann, J. 1986. Ökosystemforschung - Ergebnisse des Sollingprojekts. Ulmer, Stuttgart.

Gauer, J., Aldinger, E. 2005. Waldökologische Naturräume Deutschlands - Forstliche Wuchsgebiete und Wuchsbezirke. Mitteilungen des Vereins für Forstliche Standortskunde und Forstpflanzenzüchtung 43: 1-324.

Gerlach, A. 1970. Wald- und Forstgesellschaften im Solling. Schriftenreihe für Vegetationskunde 5: 79-98.

Meesenburg, H., Brumme, R., Jacobsen, C., Meiwes, K.J., Eichhorn, J. 2009. Soil Properties. In: Brumme, R., Khanna, K. (eds.). Functioning and Management of European Beech Ecosystems. Ecological Studies 208: 33-47.

Niedersächsische Landesregierung 1991. Langfristige, Ökologische Wald-Entwicklung in Niedersachsen. URL: http://www.landesforsten.de/Schuetzen-Gestalten.5.0.html.

NMELF (Niedersächsisches Ministerium für Ernährung, Landwirtschaft und Forsten) 1996. Waldentwicklung Solling - Fachgutachten. Schriftenreihe Waldentwicklung in Niedersachsen 5: 1-149.

NMELV (Niedersächsisches Ministerium für Ernährung, Landwirtschaft und Verbraucherschutz) 2007. Langfristige Ökologische Wald-Entwicklung in Niedersachsen - Runderlass. URL: http://www.landesforsten.de/SchuetzenGestalten.5.0.html

NMELV (Niedersächsisches Ministerium für Ernährung, Landwirtschaft und Verbraucherschutz) 2004. Langfristige Ökologische Waldentwicklung - Richtlinie zur Baumartenwahl. Aus dem Walde - Schriftenreihe Waldentwicklung Niedersachsen 54: 1-145.

Weckesser, M. 2003. Die Bodenvegetation von Buchen-Fichten-Mischbeständen im Solling - Struktur, Diversität und Stoffhaushalt. Cuvillier, Göttingen. 
Zerbe, S. 1993. Fichtenforste als Ersatzgesellschaften von Hainsimsen-Buchenwäldern. Berichte des Forschungszentrums Waldökosysteme A100: 1-173. 


\section{Chapter 3}

Short-term effects of selection and clear cutting on the shrub and herb layer vegetation during the conversion of even-aged Norway spruce stands into mixed stands

Steffi Heinrichs \& Wolfgang Schmidt (2009) Forest Ecology and Management 258: 667-678.
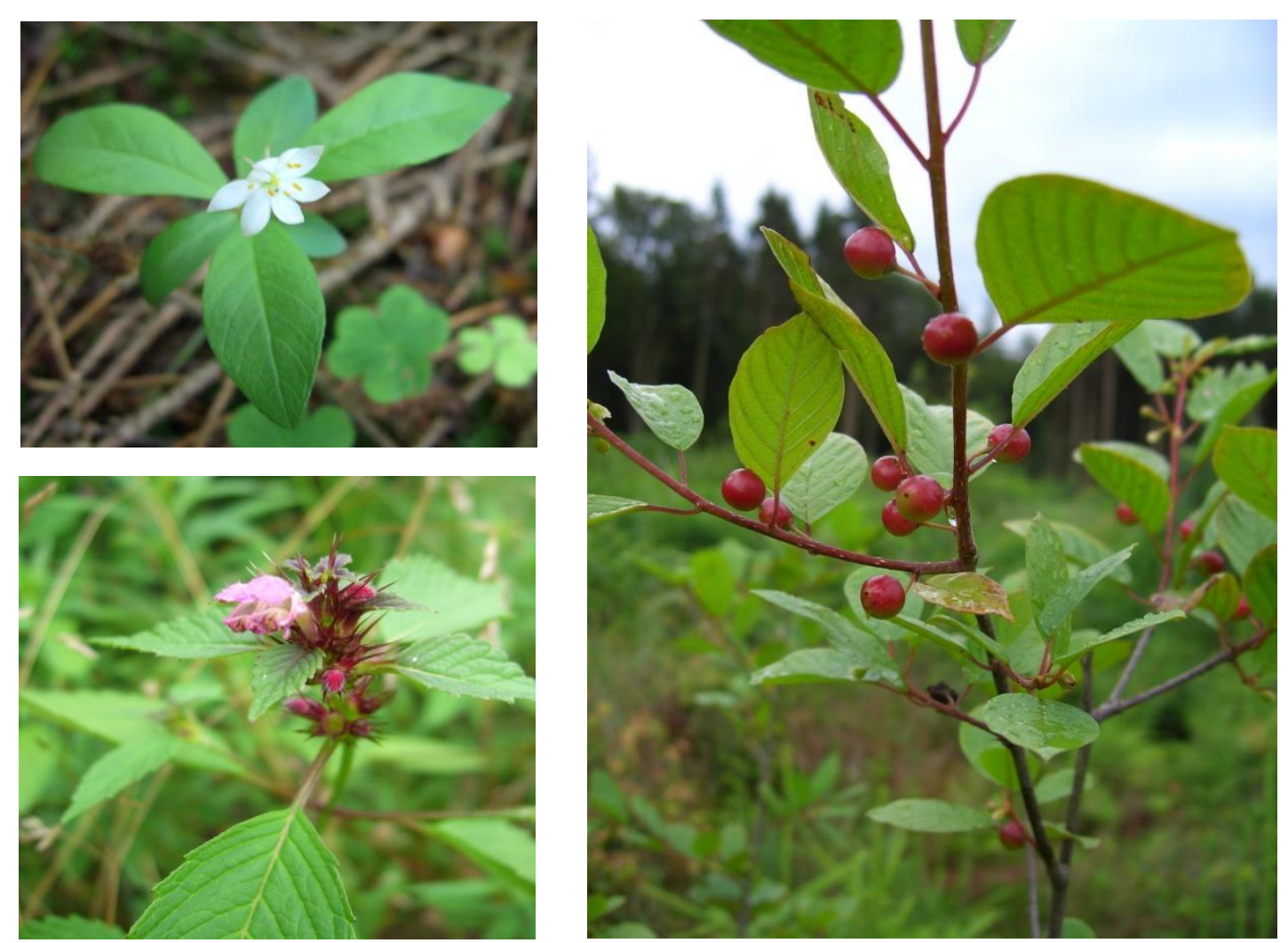
Top left: Trientalis europaea; Bottom left: Galeopsis tetrahit; Right: Frangula alnus. Photographs taken by Steffi Heinrichs. 


\section{Abstract}

The conversion of even-aged Norway spruce (Picea abies (L.) Karst.) stands into more site adapted mixed stands is the main silvicultural goal in Germany and many other European countries. The conversion will primarily be achieved with the help of selection cutting, removing single target diameter trees and creating small gaps. At sites highly susceptible to windthrow, however, small scale clear cutting (up to 1 ha) might be an appropriate alternative. Both selection and clear cutting will affect the understorey vegetation, an important component of forest biodiversity and ecosystem functioning. Thus, with the help of a BACI-experiment (before-after/control-impact), the short-term effects of selection and small scale clear cutting on the herb and shrub layer vegetation were studied at two sites in the Solling Hills (Lower Saxony, Germany). Both treatments led to an increase in herb and shrub layer species numbers, due to persistent and invading (mainly pioneer tree species and indicators of disturbance) species and to a shift in plant traits. Most responsible for the changes in vegetation was a higher light availability, and to a lesser degree soil disturbance. The number of annuals and ruderals, however, increased only immediately after clear cutting, whereas on selection cutting plots the numbers remained high. Gaining in number and coverage were competitive perennials (Epilobium angustifolium, Juncus effusus, Rubus idaeus) especially on the clear cuttings, fulfilling a nutrient retention function. The competitives did not deter tree species from regenerating in the clear cut plots, whereas on selection cutting plots the large expansion of $R$. idaeus appeared to be hindering tree colonisation. Suffering under clear cut conditions were predominantly shade-tolerant, closed-forest species, but no loss of these species could be detected. This indicates the potential for a fast recovery of these forest species, as soon as pioneer trees expand.

Although the vegetation changed in similar directions at both study sites, differences in species numbers and composition were found, indicating the importance of site conditions in the beginning of succession.

In conclusion, our study shows no overall negative effects on shrub and herb layer biodiversity and trait composition after clear cutting. It is suggested that small scale clear cutting may be considered an appropriate alternative to silvicultural methods which cause a moderate rate of disturbance, to reach the goal of Norway spruce forest conversion. 
Keywords: Species richness, Disturbance, Forest management, BACI-experiment, GLMM

\section{Introduction}

In the last two centuries Norway spruce (Picea abies (L.) Karst.) was often favoured for site reforestation in the temperate and boreal zones of Europe, because this species is easy to establish and has a high annual production (Spiecker, 2003). Today, Norway spruce grows outside its natural range, resulting in negative ecological impacts at many sites. The even-aged spruce stands are susceptible to windthrow and bark beetle attacks and lead to soil acidification and nitrogen leaching (Rothe et al., 2002; Spiecker et al., 2004). To maintain sustainability, regarding not only economical timber production, but also the ecological, sociological, and cultural functions of forests (United Nations, 1992; Beese, 1996; Lindenmayer et al. 2000), the conversion of existing Norway spruce forests into more natural broadleaved and mixed forests is the main silvicultural aim in Germany (Otto, 1995), as well as in many other European countries (Olsthoorn et al. 1999; Wulf, 2003; Lüpke, 2004) Thereby, mainly Fagus sylvatica L. and other secondary broadleaved trees will be introduced to the stands; however, in view of greater disturbances expected in the future due to climate change also the resilient and productive Pseudotsuga menziesii (Mirb.) Franco will be considered, to enhance stability and resource use (Hapla, 2000; Lüpke, 2004).

In general, a long term conversion with the creation of small gaps, with natural and planted regeneration within these gaps, is intended to maintain a multifunctional forest ecosystem (Beese, 1996; Zerbe, 2002; Spiecker, 2003; Spiecker et al., 2004). In forests with a high stand age or on waterlogged soils, which are highly susceptible to windthrow, a faster conversion with the help of larger gaps or small scale clear cuttings might be more suitable in order to avoid large scale salvage cuttings, resulting in irregular harvesting procedures with high costs and disturbed timber markets (Spiecker, 2003; Lüpke, 2004).

The removal of trees will especially affect the diversity and composition of the understorey vegetation, including shrub, herb and moss layer, an important forest ecosystem component regarding biodiversity and nutrient cycling (Rieley et al., 1979; Gilliam, 2007). Following cutting operations, the microclimate changes and soil is disturbed, resulting in a more heterogeneous environment, which promotes species richness due to invading non-forest species (Huston, 1994), but also may lead to the extirpation of very sensitive forest-taxa (Reader, 1987; Frisvoll and Prestø, 1997; 
Hannerz and Hånell, 1997; Roberts and Zhu, 2002; Godefroid et al., 2005). Furthermore, depending on the conversion method, the disturbance of the understorey vegetation varies in spatial extent, time and magnitude, favouring different life history strategies and growth forms, and resulting in different patterns of species diversity and composition (Denslow, 1980; Halpern, 1989; Glenn-Lewin and van der Maarel, 1992). Nonetheless, direct comparisons of the different silvicultural treatments in combination with a temporal (before-after) and/or a spatial (control-impact) control are scarce. Exceptions can be found for boreal forests, where selection cutting plots showed increased species richness compared to the initial situation and clear cuttings at the same site. On the clear cut plots, more species became eliminated and single species became dominant (Hannerz and Hånell, 1997; Jalonen and Vanha-Majamaa, 2001). This allowed the authors to consider the selection system as an intermediate rate of disturbance, compared to clear cutting and unmanaged forests that are characterised by natural disturbance (Huston, 1994), which is more favourable than clear cutting. Due to dispersal limitations, the early loss of species after treatment can be crucial in directing further succession (Brunet and Oheimb, 1998; Ehrlén and Eriksson, 2000). This applies also to the increasing dominance of competitive species directly after treatment. These species compete with regenerating trees and can avert their establishment and growth, resulting in a slow recovery of the forest ecosystem (Kirby, 1990; Prach and Pyšek, 1999; Diaci, 2002). Although the knowledge of early changes in shrub and herb layer diversity and composition during Norway spruce forest conversion is important to predict the development of the subsequent tree population, studies in Germany in the past were limited to comparing the understorey vegetation in Norway spruce stands with already-existing mixed stands (Gärtner and Reif, 2004, 2005; Weckesser, 2003). However, with the help of a large scale and long-term before-after/control-impactexperiment (BACI; Bennett and Adams, 2004), established by the Northwest German Forest Research Station in 2002, the short-term impact of selection cutting and small scale clear cutting on the diversity and composition of the shrub and herb layer vegetation can be investigated and monitored in the future. Due to this design, the importance of species present before the treatment can be considered, as well as the interannual fluctuation of the herb layer caused by differences in precipitation, temperature, and other factors (Brunet and Tyler, 2000; Tyler, 2001). Furthermore, the experiment was established at two sites, differing slightly in climate, stand age and stand 
history, making it possible to consider the importance of site conditions during the conversion process.

We addressed the following questions: (1) How does species diversity and composition change immediately after disturbance, and is there a distinct difference between clear cutting and selection harvesting? (2) How do individual species vary in their response to the different disturbance intensities? Is the shift towards indicators of disturbance (annuals, ruderals, open site species) more intense on the clear cut plots than on the selection cutting plots? (3) Does the forest community respond to the different disturbance intensities? If so, is light availability responsible for these changes? (4) Can clear cutting be an appropriate silvicultural alternative at sites susceptible to windthrow?

\section{Materials and methods}

\section{Site description}

The study was carried out in Norway spruce stands at two different sites (Otterbach

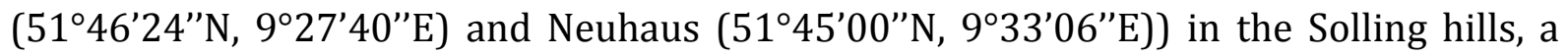
low mountain range (up to $528 \mathrm{~m}$ above sea level) in the north-western part of Central Germany. The Solling is formed on Triassic sandstone covered with loess. Predominant are more or less podzolic brown soils (Dystric Cambisols) with a low base saturation but good water supply (Ellenberg et al., 1986).

Climatically, the Solling can be separated into two regions: The study site Otterbach is situated in the lower Solling region (280 - $300 \mathrm{~m}$ above sea level), with a mean annual precipitation of $915 \mathrm{~mm}$ and a mean annual temperature of $7.8{ }^{\circ} \mathrm{C}$. The site Neuhaus represents the high Solling (509 $\mathrm{m}$ above sea level), which has a higher annual precipitation (1029 $\mathrm{mm}$ ) and lower temperatures (7.3 ${ }^{\circ} \mathrm{C}$ ) (Gauer and Aldinger, 2005).

Both sites had been naturally dominated by a species-poor beech forest (LuzuloFagetum), but an intensive forest use, since the Middle Ages, led to the degradation of the forest sites. For reforestation, the regionally non-native Norway spruce was planted in the Solling (Gerlach, 1970; Ellenberg et al., 1986).

Today, both forest sites are dominated by 90- (Otterbach) and 109- (Neuhaus) year-old Norway spruce plantations (Galio harcynici-Culto-Piceetum; Zerbe, 1993) characterised by Dryopteris dilatata, Galium saxatile, Trientalis europaea and Vaccinium myrtillus within the herb layer. Nevertheless, these stands still contain species distinctive for beech forests on acidic soils (Carex pilulifera, Luzula luzuloides). Most abundant at both 
sites is Oxalis acetosella, typical for acidic forest soils with sufficient water and nutrient supplies. This species has been especially favoured by amelioration liming (Schmidt, 2002), which took place twice in Neuhaus (1990 and 2001) and only once in Otterbach (1990).

\section{Experimental design and data survey}

At each of the two study sites (Neuhaus and Otterbach), six experimental plots of 1 ha were established. The applied treatments were clear cutting, selection cutting and unmanaged control, each repeated twice. The plots were subdivided into 20 permanent subplots (20 x $20 \mathrm{~m}$ ) separated by skidding tracks of 5 to $10 \mathrm{~m}$ in width, on which slash was piled. The treatments took place in the autumn of 2003. The selection cutting followed a target diameter harvesting regime, removing, in general, single trees with a $\mathrm{dbh} \geq 45 \mathrm{~cm}$ throughout the stand. This cutting regime will be repeated in 5-year cycles until the regeneration is established. Then the final cutting will follow. The first cutting resulted in a $24 \%$ (Otterbach) to $28 \%$ (Neuhaus) reduction of basal area and stand volume. This reduction increased after 2004 due to the occurrence of winter storms, especially in Otterbach. Some trees were also lost on the unmanaged plots (Table 1).

After the initial treatment, the natural spruce regeneration was removed from the subplots, and either beech or Douglas fir saplings were planted. On four subplots natural spruce saplings were allowed to develop.

Table 1 Characterisation of the analysed stands before treatment (2002), directly after treatment (2004) and four years after treatment (2007) at the study sites Neuhaus and Otterbach.

\begin{tabular}{|c|c|c|c|c|c|c|}
\hline & \multicolumn{3}{|c|}{ Neuhaus } & \multicolumn{3}{|c|}{ Otterbach } \\
\hline & 2002 & 2004 & 2007 & 2002 & 2004 & 2007 \\
\hline \multicolumn{7}{|l|}{ basal area $\left[\mathrm{m}^{2} / \mathrm{ha}\right]$} \\
\hline Control & 48.4 & 48.4 & 47.5 & 46.2 & 46.2 & 31.5 \\
\hline Selection cutting & 45.1 & 32.5 & 32.2 & 47.6 & 36.1 & 20.8 \\
\hline Clear cutting & 44.4 & / & / & 45.4 & / & / \\
\hline \multicolumn{7}{|c|}{ stand volume $\left[\mathrm{m}^{3} / \mathrm{ha}\right]$} \\
\hline Control & 621 & 621 & 609 & 662 & 662 & 452 \\
\hline Selection cutting & 539 & 389 & 385 & 672 & 510 & 294 \\
\hline Clear cutting & 582 & / & / & 652 & / & / \\
\hline \multicolumn{7}{|l|}{ No. of stems [n/ha] } \\
\hline Control & 318 & 318 & 312 & 346 & 346 & 236 \\
\hline Selection cutting & 314 & 234 & 224 & 368 & 289 & 161 \\
\hline Clear cutting & 272 & / & / & 336 & / & / \\
\hline
\end{tabular}

As the before-after/control-impact (BACI) design was applied (Bennett and Adams, 2004), vegetation relevés were made before (2002) and after cutting (2004, 2006, and 2007), in the control and impacted stands. Within $100 \mathrm{~m}^{2}$ in the centre of each $400 \mathrm{~m}^{2}$ - 
subplot the percentage cover of the shrub (woody plants $>0.5 \mathrm{~m}$ ) and herb layer in total, as well as for each species was estimated visually as follows: $<1,1,2, \ldots, 9,10,15, \ldots, 95$, $100 \%$. The nomenclature for vascular plants follows Wisskirchen and Haeupler (1998).

\section{Data evaluation}

To determine the treatment effects on the vegetation, species richness and coverage of the shrub and herb layer were calculated for the unmanaged and the managed stands, and compared among the treatments, as well as among the different years of observation (2002, 2004, 2006, and 2007). These parameters were also compared between Neuhaus and Otterbach to identify possible differences between the two study sites.

To evaluate the functional response of the vegetation, species with different life forms, ecological strategies, and habitat preferences were compared by grouping the shrub and herb layer species as follows: i) by life form (annuals, biennials, non-woody perennials, and woody species; Klotz et al., 2002); ii) by Grime's ecological strategies (competitors $(C)$, ruderals $(R, C R)$, stress tolerators $(S, C S)$ and species with an intermediate strategy (competitive-stress-tolerant-ruderals (CSR), stress-tolerant-ruderals (SR); Klotz et al., 2002); and iii) by habitat preference (closed forest species, species of open and disturbed sites, species of both forests and open sites, and tree regeneration based on the list of vascular forest plants of hillsides and mountains in Germany (Schmidt et al., 2003)).

To determine the response of individual species to the treatments, the average cover per species and study site was calculated in the year before the treatments (2002) and four years after the treatments (2007). Furthermore, the change in frequency, which was measured as percentage of subplots per plot where a species occurred, from 2002 to 2007 was evaluated for each study site. Following Dölle et al. (2008) the species were classified as follows: $(+2)$ invader: new in 2007; $(+1)$ increasing: increase in frequency > $40 \%$; $( \pm 0)$ stable: increase or decrease in frequency < $40 \%$; $(-1)$ decreasing: decrease in frequency $>40 \%$; (-2) extirpated: extirpation in 2007.

To illustrate the response of the forest community to logging, vegetation data of the shrub and herb layer were analysed by detrended correspondence analysis (DCA), an indirect ordination method. For the characterisation of environmental conditions Ellenberg indicator values for vascular plants (Ellenberg et al., 2001) were used, in doing so only the indicator values for light, moisture, nitrogen, soil reaction and temperature 
were regarded for this study. A biplot was compiled by correlating the mean indicator values per subplot, as well as the coverage of all occurring species with the first two ordination axes. As the main interest of the study was the function of the forest community in response to treatment, the mean indicator values were weighted by coverage to incorporate changes in the abundance of all species.

Overall species numbers and cover values, and species numbers and relative abundances for the species groups were compared among the treatments, between the sites (only overall data) and among the different years of observation. These variables were regarded as fixed effects, as they have an influence on the mean of the data. But as this study was conducted using a nested plot design, where different spatial scales were nested in a hierarchical structure (subplot within plot, within replicate, within study site), the data obtained on the subplots were not independent. The nesting can have an influence on the variance of the data, which is not of interest and must therefore be considered as a random effect. Thus, generalized linear mixed models (GLMM) with log link function and Poisson error term for the analysis of species numbers per subplot were used. For arcsine square root transformed cover values and for weighted data a Gaussian distribution for the errors was assumed (Crawley, 2007).

For each year of observation, the variables, treatment and study site, were analysed as fixed effects, and the hierarchical nesting was specified as a random effect. In addition, when analysing differences between the before and after treatment situation, year, as a categorical variable, was specified as a fixed effect and also as a continuous random effect to take into account the temporal pseudoreplication.

All statistical analyses were conducted using R 2.7.1 (R Development Core Team, 2008). The packages lme4 (Bates, 2007) and vegan (Oksanen et al., 2008) were used for generalized mixed model procedure and for ordination, respectively. Results were assumed to be significant at $\mathrm{p}<0.05$.

\section{Results}

\section{Changes in species richness and coverage}

Shrub layer species numbers and cover values depicted a decrease directly after clear cutting compared to the control and the pre-treatment condition, whereas for selection cutting, as well as for the unmanaged plots there was no response (Table 2 and 3). In 2006, species numbers exceeded those prior to cutting for both cutting treatments, increasing most notably on the clear cut plots. There was an overall difference between 
the managed and the control plots, as on the unmanaged plots no significant changes could be detected.

Table 2 Mean species richness/100 $\mathrm{m}^{2}( \pm$ SE) of the shrub and herb layer for the year before (2002) and for three years $(2004,2006,2007)$ after treatment on control, selection cutting and clear cutting plots for the two study sites Neuhaus (NH) and Otterbach (OB). Mean values are based on two replicates per treatment per site. Replicate values were obtained by averaging 20 subplots per replicate.

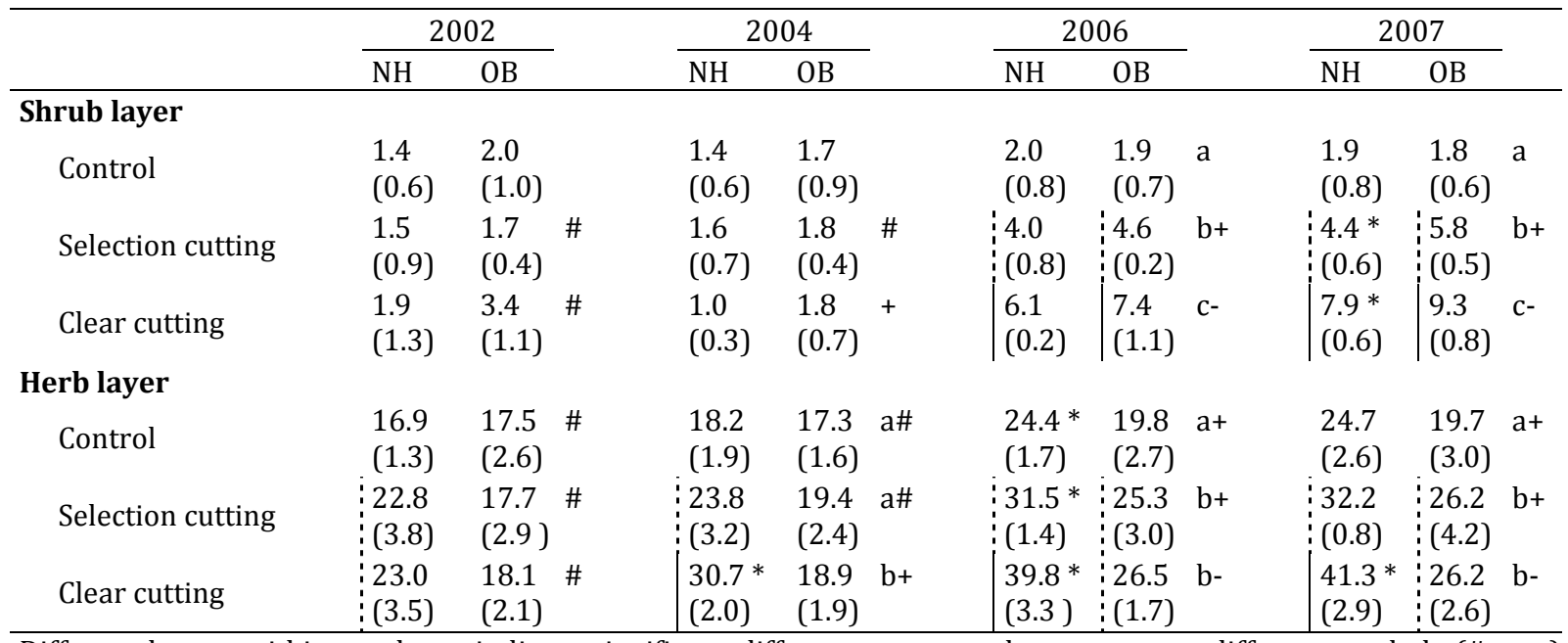

Different letters within a column indicate significant differences among the treatments, different symbols (\#, +, -) within a row indicate significant differences among the different years of observation within one treatment, * indicates significant differences between the sites, different vertical line types (including no line) show differences among the treatments within one study site (GLMM, $\mathrm{p}<0.05$; for statistical values see supplementary data: Appendix 1; Table A1 and A3).

Table 3 Mean coverage [\%] ( \pm SE) of the shrub and herb layer in the year before (2002) and for three years (2004, $2006,2007)$ after treatment on control, selection cutting and clear cutting plots for the two study sites Neuhaus (NH) and Otterbach (OB). Mean values are based on two replicates per treatment per site. Replicate values were obtained by averaging 20 subplots per replicate.

\begin{tabular}{|c|c|c|c|c|c|c|c|c|c|c|c|c|}
\hline & \multicolumn{2}{|c|}{2002} & & \multicolumn{2}{|c|}{2004} & & \multicolumn{2}{|c|}{2006} & & \multicolumn{2}{|c|}{2007} & \\
\hline & $\mathrm{NH}$ & OB & & $\mathrm{NH}$ & OB & & $\mathrm{NH}$ & OB & & $\mathrm{NH}$ & $\mathrm{OB}$ & \\
\hline \multicolumn{13}{|l|}{ Shrub layer } \\
\hline Control & $\begin{array}{l}0.9 \\
(0.8)\end{array}$ & $\begin{array}{l}1.2 \\
(1.2)\end{array}$ & $\mathrm{a}$ & $\begin{array}{l}1.8 \\
(1.7)\end{array}$ & $\begin{array}{l}0.4 \\
(0.4)\end{array}$ & & $\begin{array}{l}2.4 \\
(2.1)\end{array}$ & $\begin{array}{l}0.8 \\
(0.7)\end{array}$ & $\mathrm{a}$ & $\begin{array}{l}3.2 \\
(2.8)\end{array}$ & $\begin{array}{l}0.5 \\
(0.4)\end{array}$ & $\mathrm{a}$ \\
\hline Selection cutting & $\begin{array}{l}0.9 \\
(0.8)\end{array}$ & $\begin{array}{l}0.5 \\
(0.4)\end{array}$ & $a b \#$ & $\begin{array}{l}2.5 \\
(1.8)\end{array}$ & $\begin{array}{l}0.5 \\
(0.3)\end{array}$ & $\#$ & $\begin{array}{l}9.3 \\
(6.5)\end{array}$ & $\begin{array}{l}11.9 \\
(5.5)\end{array}$ & $\mathrm{b}+$ & $\begin{array}{l}12.7 \\
(8.5)\end{array}$ & $\begin{array}{l}20.2 \\
(8.6)\end{array}$ & $b+$ \\
\hline Clear cutting & $\begin{array}{l}4.9 \\
(4.6)\end{array}$ & $\begin{array}{l}4.7 \\
(3.6)\end{array}$ & $\mathrm{b \#}$ & $\begin{array}{l}0.5 \\
(0.4)\end{array}$ & $\begin{array}{l}2.2 \\
(2.1)\end{array}$ & + & $\begin{array}{l}6.9 \\
(1.3)\end{array}$ & $\begin{array}{l}12.3 \\
(2.6)\end{array}$ & b- & $\begin{array}{l}13.8 \\
(2.3)\end{array}$ & $\begin{array}{l}20.6 \\
(5.8)\end{array}$ & b- \\
\hline \multicolumn{13}{|l|}{ Herb layer } \\
\hline Control & $\begin{array}{l}34.4 \\
(24.2)\end{array}$ & $\begin{array}{l}16.9 \\
(7.3)\end{array}$ & $\#$ & $\begin{array}{l}48.8 \\
(31.8)\end{array}$ & $\begin{array}{l}22.0 \\
(9.0)\end{array}$ & + & $\begin{array}{l}49.2 \\
(36.7)\end{array}$ & $\begin{array}{l}23.3 \\
(9.9)\end{array}$ & +- & $\begin{array}{l}48.4 \\
(36.7)\end{array}$ & $\begin{array}{l}17.7 \\
(2.9)\end{array}$ & a\#- \\
\hline Selection cutting & $\begin{array}{l}30.0 \\
(21.3)\end{array}$ & $\begin{array}{l}16.9 \\
(1.0)\end{array}$ & $\#$ & $\begin{array}{l}55.0 \\
(23.0)\end{array}$ & $\begin{array}{l}27.6 \\
(7.7)\end{array}$ & + & $\begin{array}{l}58.7 \\
(21.1)\end{array}$ & $\begin{array}{l}25.5 \\
(3.6)\end{array}$ & +- & $\begin{array}{l}58.9 \\
(17.6)\end{array}$ & $\begin{array}{l}25.2 \\
(0.8)\end{array}$ & $a b-$ \\
\hline Clear cutting & $\begin{array}{l}30.9 \\
(11.2)\end{array}$ & $\begin{array}{l}20.8 \\
(1.7)\end{array}$ & $\#$ & $\begin{array}{l}44.0 * \\
(14.3)\end{array}$ & $\begin{array}{l}16.8 \\
(1.1)\end{array}$ & + & $\begin{array}{l}58.1 \\
(12.4)\end{array}$ & $\begin{array}{l}35.6 \\
(3.8)\end{array}$ & +- & $\begin{array}{l}64.3 \\
(12.0)\end{array}$ & $\begin{array}{l}45.9 \\
(2.1) \\
\end{array}$ & b- \\
\hline
\end{tabular}

Details see Table 2; for statistical values see supplementary data: Appendix 1; Table A2 and A4. 
The herb layer species richness increased immediately after clear cutting and, with a time delay, also after selection cutting (Table 2). The cover values, although displaying high variations, increased as well. There were, however, no significant differences between the cutting treatments except for Otterbach in 2007. This was also the case for species numbers in 2006 and 2007, but examining both study sites separately, both cutting treatments differed at Neuhaus from 2004 onwards (Table 2). In general the Neuhaus site responded faster than the Otterbach site and thus displayed higher values, especially on the clear cuts. Species numbers and cover values also increased on the control plots, but to a lesser degree compared to the other treatments (Table 2 and 3).

\section{Response of single species to treatment}

For the examination of single species responses to treatment, only the most common species at both sites were considered (frequency $>20 \%$ and coverage $>0.1 \%$ in at least one treatment in one year per study site; Table 4).

Table 4 Mean coverage (C [\%] (means < $0.1 \%=+$ )) and change in frequency (CF) following Dölle et al. (2008; for categories see text) of all species with $>20 \%$ frequency and a coverage $>0.1 \%$ in at least one treatment in 2002 or 2007 at the two study sites.

Tree regeneration
Picea abies
Sorbus aucuparia
Fagus sylvaticap
Salix caprea
Populus tremula
Betula pendula
Salix aurita
Acer pseudoplatanus
Frangula alnus
Quercus robur
Pseudotsuga menziesiip
Closed forest species
Oxalis acetosella
Gymnocarpium dryopteris
Carex remota
Impatiens noli-tangere
Moehringia trinervia
Festuca gigantea
Lysimachia nemorum
Impatiens parviflora

\begin{tabular}{|c|c|c|c|c|c|c|c|c|}
\hline \multicolumn{4}{|c|}{ Neuhaus } & \multicolumn{5}{|c|}{ Otterbach } \\
\hline Control & Selection cu & ting & Clear cutting & Control & & Selection cu & ing & Clear cutting \\
\hline CF & $\mathrm{C}$ & $\mathrm{CF}$ & $\mathrm{CF}$ & $\mathrm{C}$ & $\mathrm{CF}$ & $\mathrm{C}$ & $\mathrm{CF}$ & $\mathrm{CF}$ \\
\hline 20022007 & 20022007 & & 20022007 & 20022007 & & $2002 \quad 2007$ & & 20022007 \\
\hline
\end{tabular}

Species of forests and open sites

$\begin{array}{cccccccccccccccccc}2.5 & 4.0 & 0 & 1.8 & 2.7 & 0 & 6.2 & 1.2 & 0 & 1.2 & 0.6 & 0 & 0.6 & 0.3 & 0 & 5.6 & 7.1 & 0 \\ 0.3 & 0.2 & 0 & 0.1 & 0.5 & 0 & 0.2 & 1.2 & 0 & 0.2 & 0.1 & 0 & 0.1 & 0.2 & 0 & 0.2 & 1.3 & 0 \\ + & + & +1 & + & 3.1 & +1 & + & 4.0 & +1 & 0.1 & 0.2 & 0 & + & 1.6 & +1 & 0.1 & 3.0 & 0 \\ + & + & +1 & . & 0.2 & +2 & + & 2.1 & +1 & . & . & . & . & + & +2 & . & 0.4 & +2 \\ . & + & +2 & . & 0.1 & +2 & . & 2.1 & +2 & . & + & +2 & . & + & +2 & . & 0.2 & +2 \\ . & + & +2 & . & + & +2 & . & 0.3 & +2 & . & . & . & . & 0.1 & +2 & . & 1.3 & +2 \\ . & . & . & . & + & +2 & . & 0.4 & +2 & . & . & . & . & . & . & . & . & . \\ . & . & . & . & . & . & . & . & . & 0.1 & + & 0 & 0.1 & 0.2 & 0 & 0.6 & 0.8 & 0 \\ . & . & . & . & . & . & . & . & . & 0.1 & 0.1 & 0 & 0.1 & 0.1 & 0 & 0.1 & 0.1 & 0 \\ . & . & . & . & . & . & . & . & . & + & + & 0 & 0.3 & 0.1 & 0 & 0.2 & 0.1 & +1 \\ . & . & . & . & . & . & . & . & . & . & . & . & + & 0.5 & +1 & + & 0.9 & +1\end{array}$


Table 4 Continued

Dryopteris dilatata

Vaccinium myrtillus Rubus idaeus

Rubus fruticosus agg.

Holcus mollis

Deschampsia flexuosa

Urtica dioica

Epilobium angustifolium

Galium saxatile

Carex pilulifera

Luzula luzuloides

Trientalis europaea

Epilobium montanum

Cardamine flexuosa

Mycelis muralis

Stellaria alsine

Juncus effusus

Calamagrostis epigejos

Digitalis purpurea

Carex canescens

Ranunculus repens

Veronica officinalis

Dryopteris carthusiana

Molinia caerulea

Myosotis scorpioides

Deschampsia cespitosa

Geranium robertianum

Calluna vulgaris

Senecio sylvaticus

Poa trivialis

Taraxacum sect. Ruderalia

Galeopsis tetrahit

Pteridium aquilinum

Neuhaus

Otterbach

\begin{tabular}{|c|c|c|c|c|c|c|c|c|c|c|c|c|c|c|c|c|c|}
\hline \multicolumn{9}{|c|}{ Neuhaus } & \multicolumn{9}{|c|}{ Otterbach } \\
\hline \multicolumn{3}{|c|}{ Control } & \multicolumn{3}{|c|}{ Selection cutting } & \multicolumn{3}{|c|}{ Clear cutting } & \multicolumn{3}{|c|}{ Control } & \multicolumn{3}{|c|}{ Selection cutting } & \multicolumn{3}{|c|}{ Clear cutting } \\
\hline$c$ & & \multirow[t]{2}{*}{$\mathrm{CF}$} & \multicolumn{2}{|r|}{$\mathrm{C}$} & \multirow[t]{2}{*}{$\mathrm{CF}$} & \multirow{2}{*}{\multicolumn{3}{|c|}{$\frac{C}{20022007}$}} & \multicolumn{3}{|c|}{$\mathrm{C}$} & \multicolumn{2}{|r|}{$\mathrm{C}$} & \multirow[t]{2}{*}{$\mathrm{CF}$} & \multirow{2}{*}{\multicolumn{3}{|c|}{$\frac{C}{20022007}$}} \\
\hline \multicolumn{2}{|c|}{$\overline{20022007}$} & & 2002 & 2007 & & & & & 2002 & 2007 & $\overline{\mathrm{CF}}$ & 2002 & 2007 & & & & \\
\hline 1.0 & 1.8 & 0 & 1.5 & 2.1 & 0 & 1.3 & 0.1 & 0 & 4.7 & 5.5 & 0 & 3.5 & 5.6 & 0 & 4.8 & 1.2 & 0 \\
\hline 2.0 & 2.3 & 0 & 1.1 & 3.5 & 0 & 1.2 & 1.9 & 0 & 0.1 & 0.2 & 0 & 0.1 & 0.1 & +1 & 0.3 & 1.0 & 0 \\
\hline 0.7 & 2.5 & 0 & 0.7 & 8.3 & 0 & 1.0 & 7.5 & 0 & 2.6 & 2.6 & 0 & 1.9 & 22.5 & 0 & 1.9 & 11.1 & 0 \\
\hline 0.2 & + & 0 & 0.2 & 2.6 & 0 & 0.5 & 1.9 & +1 & 0.2 & 0.3 & 0 & 0.1 & 2.2 & 0 & 0.3 & 4.2 & 0 \\
\hline+ & + & 0 & 0.1 & 0.3 & 0 & 0.2 & 4.1 & 0 & + & 0.1 & 0 & + & 0.1 & 0 & + & 0.2 & +1 \\
\hline 1.0 & 0.2 & 0 & 0.3 & 3.3 & 0 & 0.2 & 3.5 & 0 & 0.1 & 0.5 & 0 & 0.1 & 0.7 & 0 & 0.1 & 5.3 & 0 \\
\hline 0.1 & 0.4 & 0 & 0.4 & 0.3 & 0 & 0.2 & 0.2 & 0 & + & + & -1 & 0.1 & 0.1 & -1 & 0.1 & + & -1 \\
\hline 0.1 & 0.1 & 0 & 0.1 & 3.0 & 0 & 0.1 & 8.7 & +1 & + & + & 0 & + & 0.3 & +1 & + & 2.7 & +1 \\
\hline 0.2 & 0.1 & 0 & 0.3 & 0.8 & 0 & 0.1 & 7.0 & 0 & 0.1 & 0.1 & 0 & 0.1 & 0.4 & 0 & 0.1 & 5.6 & 0 \\
\hline 0.1 & 0.1 & 0 & 0.1 & 0.4 & 0 & 0.1 & 3.9 & 0 & 0.1 & 0.2 & 0 & 0.1 & 0.5 & 0 & 0.1 & 7.6 & 0 \\
\hline 0.1 & 0.1 & 0 & 0.1 & 0.3 & 0 & 0.1 & 0.4 & 0 & 0.1 & 0.3 & 0 & 0.1 & 0.1 & 0 & 0.1 & 0.4 & 0 \\
\hline 0.1 & + & 0 & 0.1 & 0.1 & 0 & 0.1 & 0.3 & +1 & + & 0.1 & 0 & 0.1 & 0.4 & +1 & + & 0.3 & 0 \\
\hline+ & 0.1 & +1 & 0.1 & 0.4 & 0 & 0.1 & 0.2 & 0 & 0.2 & 0.3 & 0 & 0.1 & 2.2 & 0 & 0.3 & 4.2 & 0 \\
\hline 0.2 & 0.2 & 0 & 0.2 & 0.1 & 0 & 0.1 & 0.1 & 0 & . & . & . &. & r. & $\cdot$ & . & . & . \\
\hline 0.1 & 0.1 & +1 & 0.1 & 0.3 & 0 & 0.1 & 0.1 & 0 & . & . & . & 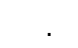 & - & - & . & . & . \\
\hline+ & + & 0 & 0.1 & 0.2 & 0 & 0.1 & 0.1 & 0 & + & + & -1 & + & 0.1 & +1 & + & . & -2 \\
\hline+ & + & 0 & + & 0.1 & +1 & + & 4.7 & +1 & + & + & -1 & + & 0.2 & +1 & + & 1.6 & +1 \\
\hline+ & + & 0 & + & 0.1 & +1 & + & 2.7 & +1 & + & + & 0 & + & 0.1 & +1 & 0.1 & 1.3 & 0 \\
\hline 0.1 & + & +1 & 0.1 & 0.5 & 0 & + & 0.7 & +1 & + & + & 0 & 0.1 & 0.2 & 0 & 0.1 & 0.1 & +1 \\
\hline+ & + & 0 & + & + & -1 & + & 0.5 & 0 & . & . & . & 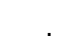 & & . & . & . & . \\
\hline . & + & +2 & + & + & 0 & + & 0.4 & +1 & . & . & . & . & . & . & . & . & . \\
\hline+ & + & +1 & . & + & +2 & + & 0.3 & +1 & . & . & . & . & . & . & . & . & . \\
\hline 0.1 & 0.1 & 0 & + & 0.1 & 0 & + & 0.1 & +1 & 0.1 & 0.3 & +1 & + & 0.2 & +1 & + & 0.1 & +1 \\
\hline+ & + & 0 & + & 0.1 & 0 & + & 0.1 & 0 & . & . & . & . & . & . & . & . & . \\
\hline . & + & +2 & + & + & 0 & + & 0.1 & +1 & 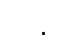 & . & r. & . & . & . & . & . & . \\
\hline . & + & +2 & + & 0.1 & +1 & + & + & +1 & . & . & . & . & . & r. & . & . & . \\
\hline . & + & +2 & 0.1 & 0.2 & +1 & + & + & +1 & . & . & . & . & 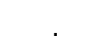 & . & . & . & . \\
\hline . &. & . & . & 0.1 & +2 & . & 1.4 & +2 & 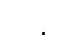 & . & $\cdot$ & . & . & . & . & 0.1 & +2 \\
\hline . & 0.1 & +2 & + & 0.2 & +2 & . & 0.2 & +2 & ${ }^{\circ}$ & . & . & . & $\cdot$ & . & . & . & . \\
\hline . & + & +2 & . & 0.1 & +2 & . & 0.1 & +2 & . & . & . & . & . & . & . & . & . \\
\hline . & + & +2 & + & 0.1 & +1 & . & + & +2 & . & . & . & r & r. & . & . & . & . \\
\hline . & . & . & . & . & . & . & . & 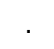 & + & + & 0 & + & 0.1 & +1 & + & + & 0 \\
\hline . & . & . & . & . & . & . & . & . & . & . & . & 0.1 & 0.3 & 0 & 1.4 & 3.8 & +1 \\
\hline
\end{tabular}

Open site species

Stellaria media

Persicaria minor

Epilobium ciliatum

Carex ovalis

Cerastium holosteoides

Cirsium vulgare

Cirsium arvense

Juncus squarrosus

Rumex acetosella

Carex pallescens

Agrostis stolonifera

Juncus conglomeratus

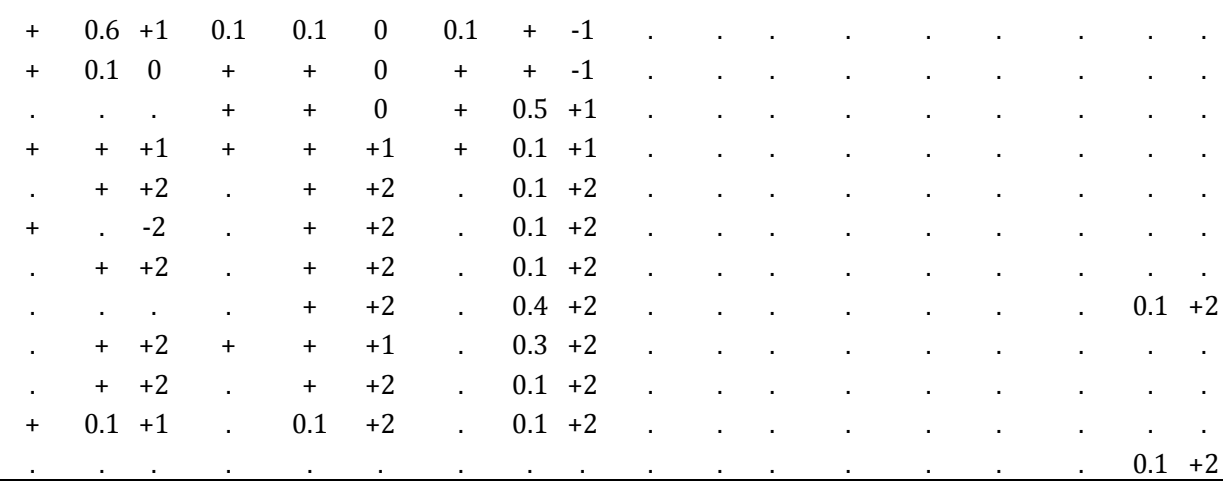

$\mathrm{p}$ partly planted species

Abundant species at both sites before the treatments were 0 . acetosella, D. dilatata and Athyrium filix-femina. Following clear cutting their coverage decreased, but increased after selection cutting. Species that increased considerably in coverage on both cutting treatments were Agrostis capillaris, Deschampsia flexuosa, Epilobium angustifolium, 
Rubus fruticosus and R. idaeus. Both Rubus species showed a substantial increase on the selection cutting plots. Increasing considerably on the clear cuts and only slightly after selection cutting were Calamagrostis epigejos, C. pilulifera, G. saxatile and Juncus effusus (Table 4). Species that newly appeared on the treated plots in 2007 were pioneer tree species (Betula pendula, Populus tremula) and predominantly open site species like Juncus squarrosus (Table 4). The latter, though, occurred with relatively low cover values compared to species already present before treatment.

In general, most species remained stable in their occurrence on all treatments; however, clear cut plots showed the lowest proportion of stable species (Fig. 1). The proportion of decreasing or disappearing species was generally low, whereas the cumulative percentage of new and increasing species comprised up to $50 \%$ of all species considered on the managed plots. At Neuhaus, the control plots had high numbers of new and increasing species (Fig. 1).

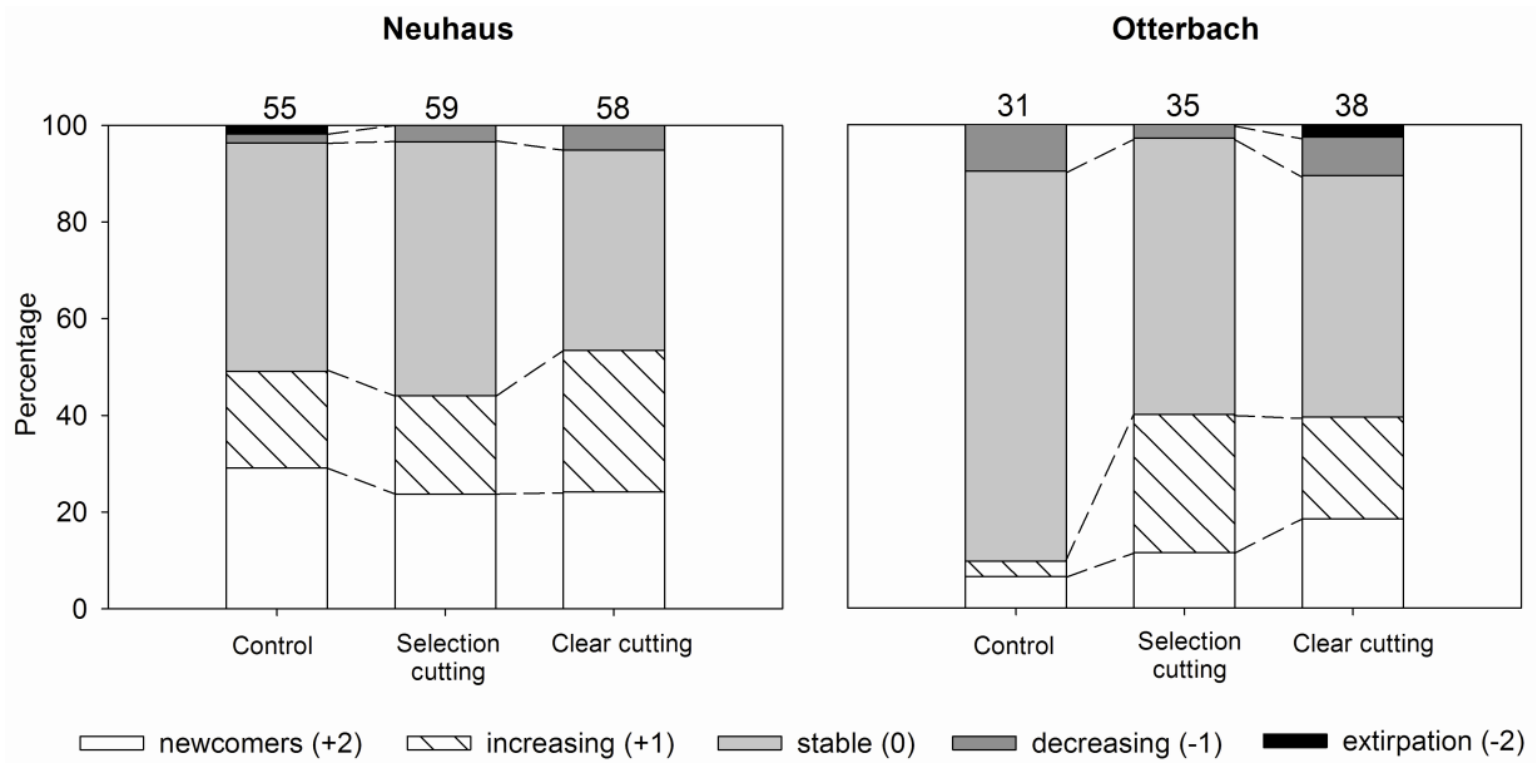

Fig. 1: Characterisation of the vegetation change from the pre-logging condition in 2002 to four years after cutting in 2007 on the three treatments at the different sites. Written above is the cumulative number of species recorded in the two years. Underlying data are shown in Table 4.

\section{Response of the forest community to treatment}

The DCA produced a separation of the two study sites along the second axis. V. myrtillus correlated positively with this second axis ( $r=0.61$; Fig. 2). Along the first axis both study sites reacted similarly. The plots prior to cutting and the control plots clustered in the left part of the ordination diagram, whereas managed plots showed species compositional changes over time, leading to an increased separation of these plots from 
the uncut situation. The clear cut plots thereby showed the strongest changes in species composition compared to the selection cutting plots.

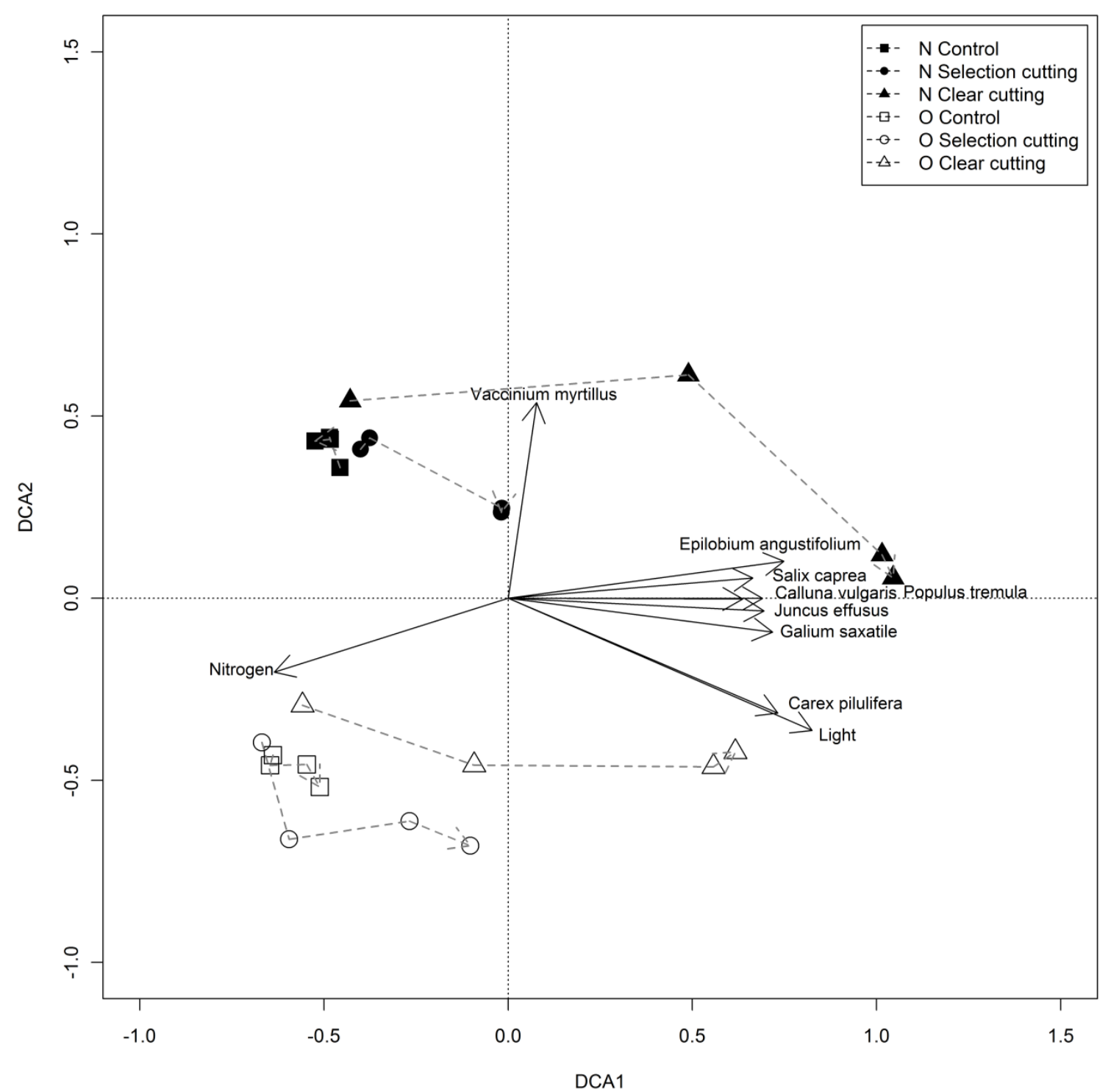

Fig. 2: DCA of the permanent subplots over the different years of observation treated either with clear cutting, selection cutting or left unharvested. Shown are the centroids of the two available replicates per site with 20 subplots each. Arrows indicate the temporal development starting in 2002 and ending in 2007. The ordination was performed with 180 species combining herb and shrub layer (Axis 1: eigenvalue $=0.30, r^{2}=46 \%$, length of gradient $=2.49$; Axis 2: eigenvalue $=0.21, r^{2}=27 \%$ ). To present a bi-plot, weighted Ellenberg indicator values for light, nitrogen, soil reaction and temperature, and the coverage of all occurring species were correlated with the axes of the ordination (correlation threshold: $r>0.6$ ), $\mathrm{N}=$ Neuhaus, $\mathrm{O}=$ Otterbach.

This change was characterised by an increasing abundance of $C$. pilulifera $(r=0.75), E$. angustifolium $(\mathrm{r}=0.74)$, G. saxatile $(\mathrm{r}=0.71)$, J. effusus $(\mathrm{r}=0.68)$, P. tremula $(\mathrm{r}=0.65)$, Salix caprea $(\mathrm{r}=0.63)$ and Calluna vulgaris $(\mathrm{r}=0.61)$, which were all positively correlated with the first axis. Moreover, the indicator value for light also showed a 
positive correlation $(r=0.82)$ with this axis, whereas the indicator value for nitrogen displayed a negative relationship $(r=-0.61)$.

\section{Response of the functional groups to treatment}

Even though species numbers of all functional groups increased, in most cases, with time on the uncut plots, the changes were small compared to the cutting treatments (Fig. 3).

On the managed plots, the number and relative cover of woody species (Table 5; Fig. 3), and the number of tree regeneration species (Table 5) increased from 2006 onwards.

Table 5 Mean species richness $/ 100 \mathrm{~m}^{2}$ ( \pm SE) of the different species groups in the year before (2002) and for three years $(2004,2006,2007)$ after treatment on control, selection cutting and clear cutting plots.

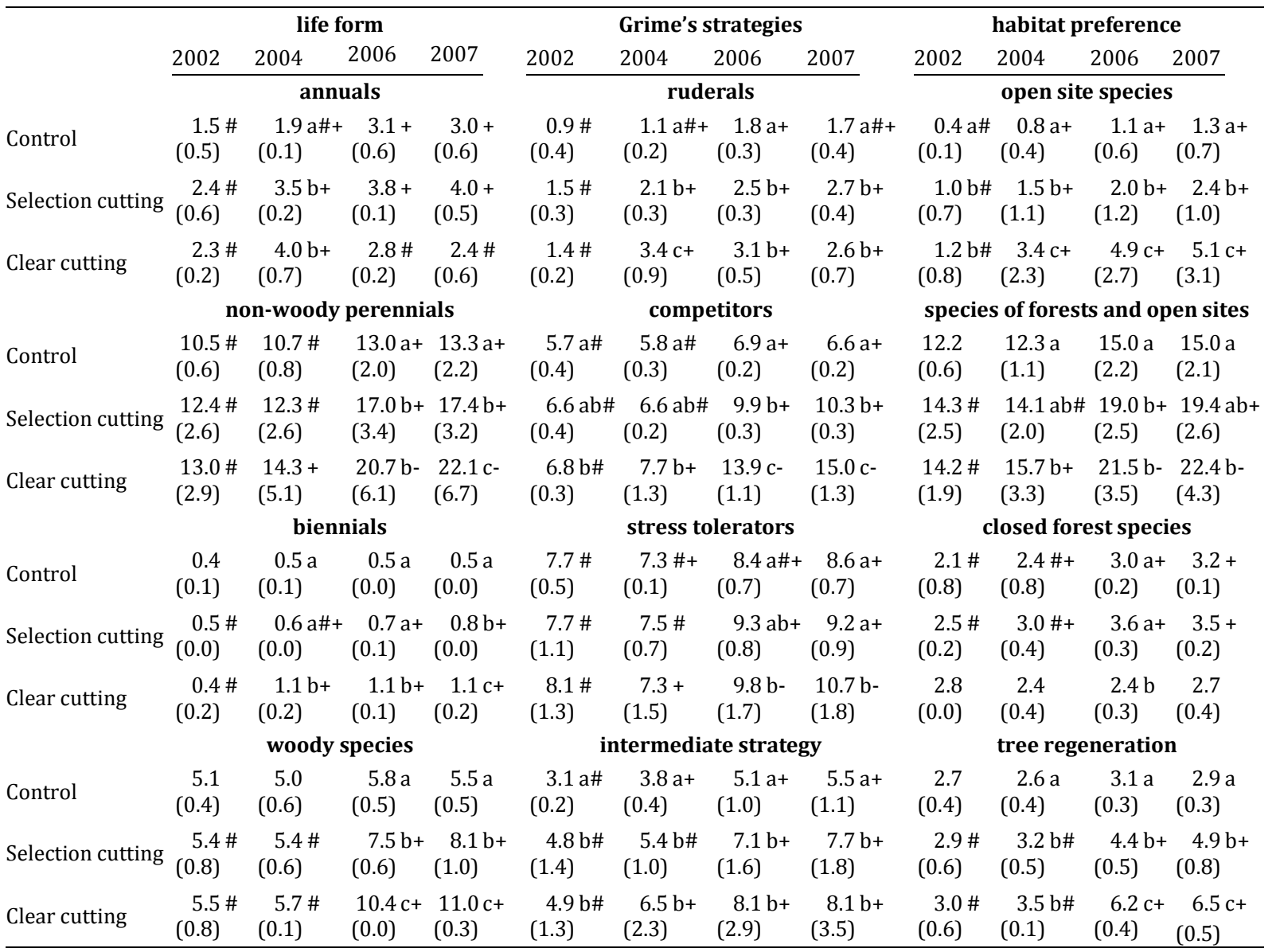

Different letters within a column indicate significant differences among the treatments, different symbols (\#, +, -) within a row indicate significant differences among different years of observation within one treatment (GLMM, p > 0.05; for statistical values see supplementary data: Appendix 1; Table A4).

On the selection cutting plots, annuals and ruderals gained in species numbers and proportional abundance (exception for ruderals; Fig. 3) immediately after cutting. In the following years their abundance declined, although their species numbers remained stable over the study period. Similarly, on the clear cutting plots there was also an 
immediate gain in proportional abundance and species numbers of annuals and ruderals which then both declined over time.
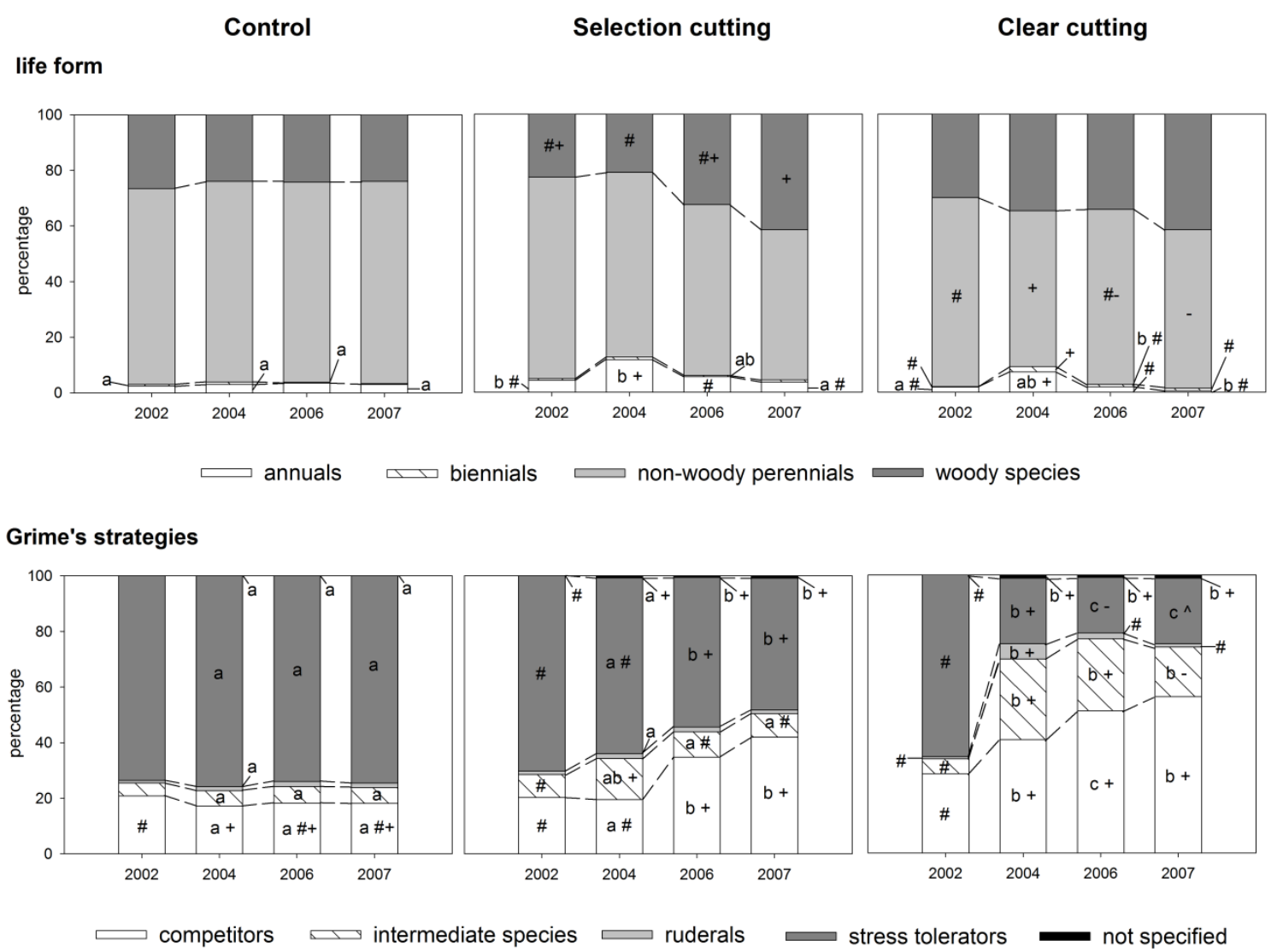

habitat preference

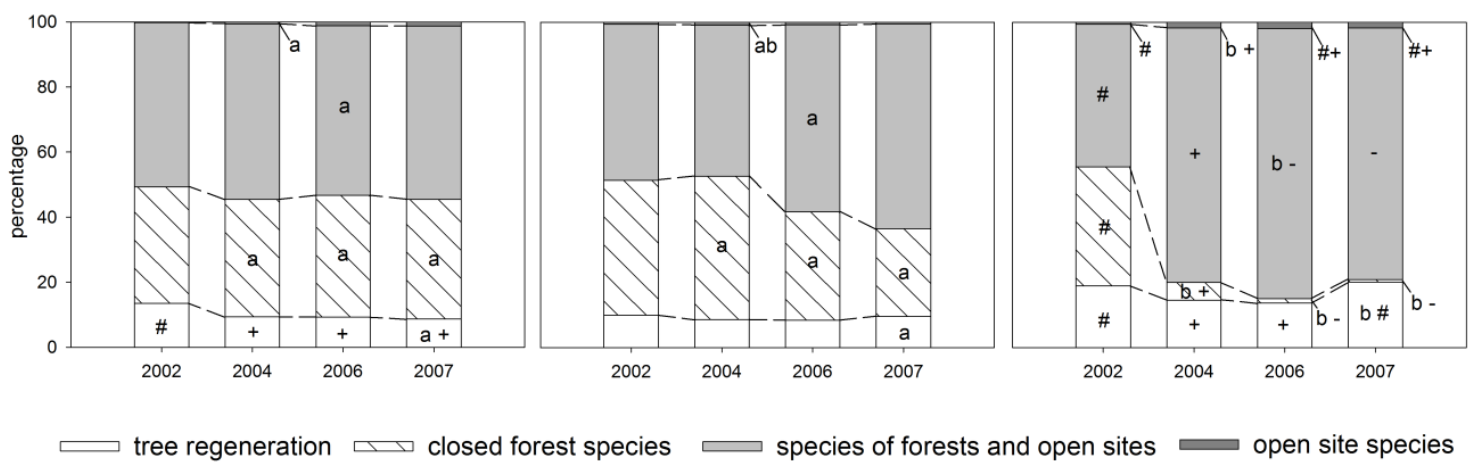

Fig. 3: Changes in growth forms, Grime's strategies and habitat preferences of all species occurring on the differently treated plots over the years of observation. Data are weighted by coverage and represent mean values of the two sites. Letters indicate differences among the different treatments within one year of observation. Different symbols $(\#,+,-$, ${ }^{\wedge}$ ) show significant differences among years within one treatment (GLMM, p $<0.05$, for statistical values see supplementary data: Appendix 1; Table A6).

The number of species typical of open and disturbed habitats increased significantly after both cutting treatments compared to the situation 2002 and compared to the 
control. Highest values were found on the clear cut plots, showing also an increase in proportional abundance (Fig. 3).

Following treatments, shade-tolerant forest species and stress tolerators were suffering the most. Their proportional abundance decreased slightly after selection cutting, but distinctively on the clear cut plots directly after harvesting and up until 2007 had not regained their pre-treatment levels. Species numbers, though, showed no persistent decline after clear cutting and even increased significantly in 2006.

Competitive species increased in numbers (Table 5) and abundance (Fig. 3) after clear cutting and to a lesser extent also after selection cutting.

\section{Discussion}

Species diversity

Herb layer species diversity increased either immediately (clear cutting), or with a short time delay (selection cutting) after cutting compared to unmanaged stands. A gain in $\alpha$ diversity after selection or partial cutting has also been found by Hannerz and Hånell (1997) for boreal Norway spruce stands, by Thomas et al. (1999) for Douglas-fir stands, and by Götmark et al. (2005) for temperate deciduous forests, whereas results for clear cuttings are diverse. Hannerz and Hånell (1997) reported a decrease in species richness on four clear cut sites in the first two years after treatment. This is supported by Jalonen and Vanha-Majamaa (2001) for other mature boreal spruce forests. Dierschke (1978, 1988), Roberts and Zhu (2002), Pykälä (2004) and Eycott et al. (2006) found an increase in species in the first one to three year period after clear cutting mainly in herb rich forests of the temperate and boreal zones. The increases detected in the Solling are likely to be the consequence of a higher environmental heterogeneity (Huston, 1994) regarding the light availability and soil disturbance after both cutting treatments, favouring especially light-demanding and wind-dispersed annuals and ruderals, capable of a fast dispersal to the plots from adjacent open areas or forest tracks (McIntyre et al. 1995). Recurrent small disturbances in the soil and the canopy due to falling branches, or trees after windthrow on selection cutting plots, led to constant numbers regarding these species groups. Whereas, by the third year after clear cutting, species with a short life-cycle had already declined in favour of competitive perennials (E. angustifolium, J. effusus, C. epigejos) and woody species (Dierschke, 1978; Halpern, 1989; Prach et al., 1997). 
Woody perennials were mainly represented by pioneer tree species with small, wind dispersed seeds (B. pendula, P. tremula, Salix aurita and S. caprea). These species compensated the decrease in shrub species diversity detected immediately after clear cutting, a consequence of the mechanical damage to exposed regeneration buds at the time of logging (Reader, 1987).

Not only the better light supply, but also the larger degree of soil disturbance, resulting in more available colonisation sites, increased the number of open site and woody species especially on the clear cutting plots compared to the other cutting treatment (McIntyre et al., 1995; Kompa and Schmidt, 2003). Furthermore, the high abundance of $R$. idaeus and the persistent bryophyte cover on selection cutting plots might have impeded the establishment of tree species regeneration there.

Also contributing to the increase in species diversity is the behaviour of groups sensitive to disturbance or a changing microclimate, as species typical of closed forests and stress tolerators showed no persistent decline after either treatment. This supports the results of Halpern (1989), Zobel (1989) and Kompa and Schmidt (2003), who found most species surviving and occurring in the initial stages of secondary succession after stand replacing disturbance (by windthrow or cutting operations). Remaining trees, establishing Rubus-shrubs and other higher growing plants offer shelter and ensure the survival of shade-tolerant plants. In general, most forest plants are well adapted to the occurrence of canopy gaps and soil disturbance (Brunet et al., 1996, 1997).

Differences in the regional species pool can also influence the way species colonise disturbed sites and thus the species richness on a smaller scale (Zobel, 1997). At the beginning of this study, 97 species were found in Neuhaus and 85 in Otterbach. Also during the whole study period more species were recorded in Neuhaus (158) than in Otterbach (129), reflecting a larger species pool in Neuhaus and explaining higher species numbers there. Furthermore, amelioration liming took place more recently in Neuhaus than in Otterbach, probably resulting in a greater pool of non-forest species (Schmidt, 2002), which were favoured by the higher light availability after treatment, and which colonised the plots from the surroundings. Also Dierschke (1988) found differences between two clear cut plots in temperate beech forests in the initial phase after treatment and concluded that the coincidence of species already present and existing in adjacent areas is highly important.

The results of this study also show an increase in herb layer species diversity in the unmanaged plots, although this increase is less pronounced than that detected after 
both cutting treatments. This indicates year-to-year fluctuations, but reflects also disturbances by bark beetle attacks or windthrow. Increases were especially large on control plots in Neuhaus, although windthrow caused more damage in Otterbach. This again reflects the larger pool of non-forest species in Neuhaus, capable of colonizing new regeneration sites. Nevertheless, more invading species are also expected on the disturbed control plots in Otterbach in the next years, probably necessitating the use of already existing vegetation data, collected over the last 40 years within the study area in Norway spruce stands, as a reference (e.g. Gerlach, 1970; Weckesser, 2003).

\section{Vegetation structure and function}

Despite the detected changes in species diversity, the short-term vegetation succession after the cutting treatments is especially characterised by abundance changes of persistent species. Increasing in coverage particularly are C. pilulifera, J. effusus, G. saxatile and E. angustifolium on the clear cuts, but also D. flexuosa and R. idaeus after both cutting treatments. These results are, in part, consistent with Hannerz and Hånell (1997) for both treatments, Roberts and Zhu (2002) and Godefroid et al. (2005) for clear cuttings, Bergstedt et al. (2008) for different cutting intensities and Götmark et al. (2005) for selection cutting. Some species are able to survive the disturbance through rhizomes (D. flexuosa; Jonsson and Esseen, 1998). Others are known to produce a persistent seed bank and are able to germinate after soil disturbance and with increasing light availability (Hill and Stevens, 1981; Kjellson, 1985; Thompson et al., 1997). The seeds of J. effusus, E. angustifolium and D. flexuosa are all wind-dispersed and can easily reach the plots from the surroundings. In addition, all these species are able to reproduce vegetatively, enabling them to rapidly increase their coverage after surviving on the plots, germinating from the seed bank or recolonising the plots. Mayer et al. (2004) showed for example, that high light intensities favoured the vegetative spread of $R$. idaeus. In addition, the higher light intensity, compared to untreated stands, also enhances flowering of all above mentioned species, leading to a higher degree of generative regeneration on the plots as well. Consequently, these species are very competitive and account for the increasing relative abundance of competitives with time after treatment (Prach \& Pyšek, 1999). Hence, light is the most important abiotic factor influencing changes in vegetation composition during forest regeneration (Strengbom et al. 2004; Bergstedt et al. 2008; Fahey and Puettmann, 2008). 
The removal of canopy trees also increases the nitrogen and water availability, but the indicator value for nitrogen showed a negative relationship to treatment. Except for $E$. angustifolium, no nitrogen demanding species (indicator value for nitrogen > 7) increased considerably in coverage. Regarding moisture, J. effusus was the only indicator of wet sites to increase markedly in abundance. This contradicts Kirby (1990) and Hannerz and Hånell (1997), who found a shift towards more nitrogen and moisture demanding species several years after different cutting regimes. However, an increase in the abundance of nitrogen demanding species occurred also in this study immediately after treatment, as most annual and ruderal species are in general nitrophilous (e.g. Galium aparine, Senecio sylvativus; Ellenberg et al., 2001). Moreover, for the lateral expansion of perennials (resulting in a higher coverage) and for flowering (often producing a greater height growth of plants) more nutrients and moisture were needed and taken up by the vegetation (Tilman, 1988). This underlines the importance of the understorey vegetation and especially of competitive perennials and woody species for the reduction of nutrient leaching after disturbance. On the selection cutting plots, the proportion of these species groups was lower compared to on the clear cuts, indicating a smaller release of available nutrients, but also suggesting that there is a higher risk of nutrient leaching under the created gaps in old-mature stands with a low nutrient storage capacity (Bauhus and Bartsch, 1995; Huber et al., 2004; Scharenbroch and Bockheim, 2008). On these plots small growing stress-tolerators remained dominant, with regard to their abundance, whereas $O$. acetosella and different fern species (A. filixfemina, D. dilatata, Gymnacarpium dryopteris) decreased on the clear cut sites. These shade-tolerant species suffer from the rapid growth of more competitive species, or are not able to tolerate low air humidity (Godefroid et al., 2005). Despite this fact, these species remained on the clear cut plots and will probably be able to recover, as soon as the pioneer tree vegetation expands more, creating more favourable conditions for small herb layer species. Not regarded in this study were bryophytes, a group very sensitive to changes in microclimate. Due to a variety of regeneration methods, a fast recovery is, however, likely on clear cuts (Jonsson and Esseen, 1998). On selection cutting plots, a dense bryophyte cover and the expansion of $R$. idaeus seem to have interfered with the establishment and spread of regenerating tree species.

V. myrtillus showed a positive relationship with the Neuhaus site, probably reflecting its former heath- and grassland habitat prior to reforestation. The higher abundance of Calluna vulgaris following clear cutting here is another indication of its former land use. 
At the study site Otterbach, beech and oak stands dominated over centuries before the planting of Norway spruce (NMELF, 1996).

The herb layer coverage also increased significantly on the control plots, reflecting mainly interannual fluctuations (O. acetosella; Rodenkirchen, 1991; Brunet and Tyler, 2000). Changes in the abundance of the different evaluated plant traits showed nearly no response over time on the uncut plots, indicating that the changes observed on the managed plots are related to treatment.

\section{Conclusions and management implications}

Our results suggest the consideration of small scale clear cuttings as an alternative to conversion methods, characterised by a moderate rate of disturbance, as no overall negative effects on the diversity of the shrub and herb layer could be detected. The colonisation of tree species was not hampered by other competitive species, such as $R$. idaeus as seen on selection cutting plots; also species sensitive to disturbance, although decreasing in abundance, were still persistent after clear cutting, indicating the potential for a fast recovery as soon as pioneer trees expand. Moreover, due to the larger expansion of competitive species on clear cuts compared to selection cutting plots, nitrate leaching might be more effectively reduced than in small gaps (Fahey and Puettmann, 2008). In addition, these clear cuts can provide a retreat for endangered species, as Genista germanica and Lathyrus linifolius (Garve, 2004), relic species of the former heathland land use, were recorded after clear cutting.

Therefore, the conversion of Norway spruce forests into mixed forests should not be restricted to the one method of selection cutting, removing target diameter trees; instead, under consideration of site conditions, including the regional species pool, the appliance of a combination of different management regimes (with larger gaps and small scale clear cuttings) is suggested to reach the goal of conversion. Especially in areas susceptible to windthrow, a faster conversion can be appropriate. The rapid colonization of pioneer tree species early in the secondary succession, shown in this study, can then be utilized for reforesting the plots with shade-tolerant species such as Fagus sylvatica.

\section{Acknowledgements}

We would like to thank Andreas Kinser and Thomas Kompa for help with the field work, Andreas Parth for providing useful data evaluation tools (FRIDOLINO), Markus Bernhardt-Römermann for giving helpful advice concerning the statistical analyses, 
Ginamarie Gemma Lopez and Ruth Gilbert for language correction, and two anonymous reviewers for their helpful comments on the manuscript.

\section{References}

Bates, D., 2007. lme4: Linear mixed-effects models using S4 classes. R package version 0.99875-9.

Bauhus, J., Bartsch, N., 1995. Mechanisms for carbon and nutrient release and retention in beech forest gaps I. Microclimate, water balance, and seepage water chemistry. Plant Soil 168-169, 579-584.

Bennett, M. A. , Adams, M. A., 2004. Assessment of ecological effects due to forest harvesting: approaches and statistical issues. J. Appl. Ecol. 41, 585-598.

Beese, F., 1996. Indikatoren für eine multifunktionelle Waldnutzung. Forstw. Cbl. 115, 65-79.

Bergstedt, J., Hagner, M., Milberg, P., 2008. Effects of vegetation composition of a modified forest harvesting and propagation method compared with clear-cutting, scarification and planting. Appl. Veg. Sci. 11, 159-168.

Brunet, J., Oheimb, G.v., 1998. Migration of vascular plants to secondary woodlands in southern Sweden. J. Ecol. 86, 429-438.

Brunet, J, Tyler, G., 2000. Interannual variability in abundance of field layer species in a south Swedish deciduous wood. Flora 195, 97-103.

Brunet, J., Falkengren-Grerup, U., Tyler, G., 1996. Herb layer vegetation of south Swedish beech and oak forests - effects of management and soil acidity during one decade. Forest Ecol. Manage. 88, 259-272.

Brunet, J., Falkengren-Grerup, U., Tyler, G., 1997. Patterns and dynamics of the ground vegetation in Swedish Carpinus betulus forests: importance of soil chemistry and management. Ecography 20, 513-520.

Crawley, M.J., 2007. The R book. John Wiley \& Sons, Chichester.

Denslow, J.S., 1980. Patterns of plant species diversity during succession under different disturbance regimes. Oecologia 46, 18-21.

Diaci, J., 2002. Regeneration dynamics in a Norway spruce plantation on a silver firbeech forest site in the Slovenian Alps. Forest Ecol. Manage. 161, 27-38.

Dierschke, H., 1978. Vegetationsentwicklung auf Kahlschlägen verschiedener Laubwälder bei Göttingen. I. Dauerflächen-Untersuchungen 1971-1977. Phytocoenosis 7, 29-42. 
Dierschke, H., 1988. Pflanzensoziologische und ökologische Untersuchungen in Wäldern Süd-Niedersachens. IV. Vegetationsentwicklung auf langfristigen Dauerflächen von Buchenwald-Kahlschlägen. Tuexenia 8, 307-326.

Dölle, M., Bernhardt-Römermann, M., Parth, A., Schmidt, W., 2008. Changes in life history trait composition during undisturbed old-field succession. Flora 203, 508-522.

Ehrlén, J., Eriksson, O., 2000. Dispersal limitation and patch occupancy in forest herbs. Ecology 81, 1667-1674.

Ellenberg, H., Mayer, R., Schauermann, J., 1986. Ökosystemforschung - Ergebnisse des Sollingprojekts. Ulmer, Stuttgart.

Ellenberg, H., Weber, H.E., Düll, R., Wirth, V., Werner, W., 2001. Zeigerwerte von Pflanzen in Mitteleuropa. Scr. Geobot. 18, 1-264.

Eycott, A.E., Watkinson, A.R., Dolman, P.M., 2006. Ecological patterns of plant diversity in a plantation forest managed by clear felling. J. Appl. Ecol. 43, 1160-1171.

Fahey, R.T., Puettmann, K.J., 2008. Patterns in spatial extent of gap influence on understory plant communities. Forest Ecol. Manage. 255, 2801-2810.

Frisvoll, A.A., Prestø, T., 1997. Spruce forest bryophytes in central Norway and their relationship to environmental factors including modern forestry. Ecography 20, 318.

Gärtner, S., Reif, A., 2004. The impact of forest transformation on stand structure and ground vegetation in the southern Black Forest, Germany. Plant Soil 264, 35-51.

Gärtner, S., Reif, A., 2005. The response of ground vegetation to structural change during forest conversion in the southern Black Forest. Eur. J. Forest Res. 124, 221-231.

Garve, E., 2004. Rote Liste und Florenliste der Farn- und Blütenpflanzen in Niedersachsen und Bremen. Inf.dienst Nat.schutz Niedersachs. 1, 1-76.

Gauer, J., Aldinger, E., 2005. Waldökologische Naturräume Deutschlands - Forstliche Wuchsgebiete und Wuchsbezirke - mit Karte 1:1.000.000. - Mitt. Ver. Forstl. Standortskde. Forstpflanzenz. 43, 1-324.

Gerlach, A., 1970. Wald- und Forstgesellschaften im Solling. - Schr.reihe Veg.kd. 5, 79-98.

Gilliam, F.S., 2007. The ecological significance of the herbaceous layer in temperate forest ecosystems. Bioscience 57, 845-858.

Glenn-Lewin, D.C., van der Maarel, E., 1992. Patterns and processes of vegetation dynamics. In: Glenn-Lewin, D.C., Peet, P.K., Veblen, T.T. (Eds.), Plant succession theory and prediction. Chapman \& Hall, London, pp. 11-59. 
Godefroid, S., Rucquoij, S., Koedam, N., 2005. To what extent do forest herbs recover after clearcutting in beech forests? Forest Ecol. Manage. 210, 39-53.

Götmark, F., Paltto, H., Nordén, B., Götmark, E., 2005. Evaluating partial cutting in broadleaved temperate forest under strong experimental control: short term effects on herbaceous plants. Forest Ecol. Manage. 214, 124-141.

Halpern, C.B., 1989. Early successional patterns of forest species: interactions of life history traits and disturbance. Ecology 70, 704-720.

Hannerz, M., Hånell, B., 1997. Effects on the flora in Norway spruce forests following clearcutting and shelterwood cutting. Forest Ecol. Manage. 90, 29-49.

Hapla, F., 2000. Douglasie - eine Bauholzart mit Zukunft. Forst Holz 55, 728-732.

Hill, M.O., Stevens, P.A., 1981. The density of viable seed in soils of forest plantations in upland Britain. J. Ecol. 69, 693-709.

Huber, C., Weis, W., Baumgarten, M., Göttlein, A., 2004. Spatial and temporal variation of seepage water chemistry after femel and small scale clear-cutting in a $\mathrm{N}$-saturated Norway spruce stand. Plant Soil 267, 23-40.

Huston, M.A., 1994. Biological diversity: the coexistence of species on changing landscapes. University Press, Cambridge.

Jalonen, J., Vanha-Majamaa, I., 2001. Immediate effects of four different felling methods in mature boreal spruce forest understory vegetation in southern Finland. Forest Ecol. Manage. 146, 25-34.

Jonsson, B.G., Esseen, P.-A., 1998. Plant colonisation in small forest-floor patches: importance of plant group and disturbance traits. Ecography 21, 518-526.

Kirby, K.J., 1990. Changes in the ground flora of a broadleaved wood within a clear fell, group fell and a coppiced block. Forestry 63, 241-249.

Kjellsson, G., 1985. Seed fate in a population of Carex pilulifera L. II. Seed predation and its consequences for dispersal and seed bank. Oecologia 67, 424-429.

Klotz, S., Kühn, I., Durka, W., 2002. BiolFlor - Eine Datenbank mit biologischökologischen Merkmalen zur Flora von Deutschland. Schr.reihe Veg.kd. 38, 1-334.

Kompa, T., Schmidt, W., 2003. Buchenwald-Sukzession nach Windwurf auf Buntsandstein im südwestlichen Harzvorland. Tuexenia 23, 95-130.

Lindenmayer, D.B., Margules, C.R., Botkin, D.B., 2000. Indicators of biodiversity for ecologically sustainable forest management. Conserv. Biol. 14, 941-950.

Lüpke, B.v., 2004. Risikominderung durch Mischwälder und naturnaher Waldbau: ein Spannungsfeld. Forstarchiv 75, 43-50. 
Mayer, P. Abs, C., Fischer, A., 2004. Colonisation by vascular plants after soil disturbance in the Bavarian forest - key factors and relevance for forest dynamics. Forest Ecol. Manage. 188, 279-289.

McIntyre, S., Lavorel, S., Tremont, R.M., 1995. Plant life-history attributes: their relationship to disturbance response in herbaceous vegetation. J. Ecol. 83, 31-44.

NMELF (Niedersächsisches Ministerium für Ernährung, Landwirtschaft und Forsten), 1996. Waldentwicklung Solling - Fachgutachten. Schr.reihe Waldentw. Niedersachs. 5, 1-149.

Oksanen, J., Kindt, R., Legendre, P., O'Hara, B., Simpson, G.L., Stevens, M.H.H., Wagner, H., 2008. vegan: community ecology package. R package version 1.13-1. http://vegan.rforge.r-project.org/.

Olsthoorn, A.F.M., Bartelink, H.H., Gardiner, J.J., Pretzsch, H., Hekhuis, H.J., Franc, A. (Eds.), 1999. Management of mixed-species forest: silviculture and economics. Scient. Contrib. 15, 1-389.

Otto, H.-J., 1995. Die Verwirklichung des LÖWE-Regierungsprogramms. AFZ/Wald 50, 1028-1031.

Prach, K., Pyšek, P., 1999. How do species dominating in succession differ from others? J. Veg. Sci. 10, 383-392.

Prach, K., Pyšek, P., Šmilauer, P., 1997. Changes in species traits during succession: a search for pattern. Oikos 79, 201-205.

Pykälä, J., 2004. Immediate increase in plant species richness after clear cutting of boreal herb-rich forests. Appl. Veg. Sci. 7, 29-34.

R Development Core Team, 2008. R: A language and environment for statistical computing. R Foundation for Statistical Computing, Vienna, Austria. http://www.Rproject.org.

Reader, R.J., 1987. Loss of species from deciduous forest understorey immediately following selective tree harvesting. Biol. Conserv. 42, 231-244.

Rieley, J.O., Richards, P.W., Bebbington, A.D.L., 1979. The ecological role of bryophytes in a North Wales woodland. J. Ecol. 67, 497-527.

Roberts, M.R., Zhu, L., 2002. Early responses of the herbaceous layer to harvesting in a mixed-coniferous-deciduous forest in New Brunswick, Canada. Forest Ecol. Manage. $155,17-31$. 
Rodenkirchen, H., 1991. Entwicklung der Waldbodenvegetation auf den Versuchsflächen des Höglwald-Experiments im Beobachtungszeitraum 1983-1989. Forstwiss. Forsch. 39, 74-86.

Rothe, A., Huber, C., Kreutzer, K., Weis, W., 2002. Deposition and soil leaching in stands of Norway spruce and European beech: results from the Höglwald research in comparison with other European case studies. Plant Soil 240, 33-45.

Scharenbroch, B.C., Bockheim, J.G., 2008. The effects of gap disturbance on nitrogen cycling and retention in late successional northern hardwood-hemlock forests. Biogeochemistry 87, 231-245.

Schmidt, M., Ewald, J., Fischer, A., v. Oheimb, G., Kriebitzsch, W.-U., Ellenberg, H., Schmidt, W., 2003. Liste der in Deutschland typischen Waldgefäßpflanzen. Mitt. Bundesforschungsanst. Forst-Holzwirtschaft 212, 1-32.

Schmidt, W., 2002. Einfluss der Bodenschutzkalkungen auf die Waldvegetation. Forstarchiv 73, 43-54.

Spiecker, H., 2003. Silvicultural management in maintaining biodiversity and resistance of forests in Europe - temperate zone. J. Environ. Manage. 67, 55-65.

Spiecker, H., Hansen, J., Klimo, E., Skovgaard, J.P., Sterba, H., Teuffel, K. v. (Eds), 2004. Norway spruce conversion - options and consequences. European Forest Institute Research Report 18, 1-269.

Strengbom, J., Näsholm, T., Ericson, L., 2004. Light, not nitrogen, limits growth of the grass Deschampsia flexuosa in boreal forests. Can. J. Bot. 82, 430-435.

Thomas, S.C., Halpern, C.B., Falk, D.A., Liguori, D.A., Austin, K.A., 1999. Plant diversity in managed forests: understory responses to thinning and fertilization. Ecol. Appl. 9, 864-879.

Thompson, K., Bakker, J., Bekker, R., 1997. The soil seed banks of North West Europe: methodology, density and longevity. University Press, Cambridge.

Tilman, D., 1988. Plant strategies and the dynamics and structure of plant communities. University Press, Princeton.

Tyler, G., 2001. Relationships between climate and flowering of eight herbs in a Swedish deciduous forest. Ann. Bot. 87, 623-630.

United Nations, 1992. Agenda 21: the United Nations programme of action from Rio. United Nations, New York.

Weckesser, M., 2003. Die Bodenvegetation von Buchen-Fichten-Mischbeständen im Solling - Struktur, Diversität und Stoffhaushalt. Cuvillier, Göttingen. 
Wisskirchen, R., Haeupler, H., 1998. Standardliste der Farn- und Blütenpflanzen Deutschlands. Ulmer, Stuttgart.

Wulf, M., 2003. Forest policy in the EU and its influence on the plant diversity of woodlands. J. Environ. Manage. 67, 15-25.

Zerbe, S., 1993. Fichtenforste als Ersatzgesellschaften von Hainsimsen-Buchenwäldern. Ber. Forsch. zent. Waldökosyst. A100, 1-173.

Zerbe, S., 2002. Restoration of natural broad-leaved woodland in Central Europe on sites with coniferous plantations. Forest Ecol. Manage. 167, 27-42.

Zobel, M., 1989. Secondary forest succession in Järvselja, southeastern Estonia: changes in field layer vegetation. Ann. Bot. Fennici 26, 171-182.

Zobel, M., 1997. The relative role of species pools in determining plant species richness: an alternative explanation of species coexistence? Trends Ecol. Evol. 12, 266-269. 


\section{Chapter 4}

4.1

The estimation of aboveground biomass and nutrient pools of understorey plants in closed Norway spruce forests and on clear cuts

Steffi Heinrichs, Markus Bernhardt-Römermann \& Wolfgang Schmidt (2010)

European Journal of Forest Research 129: 613-624

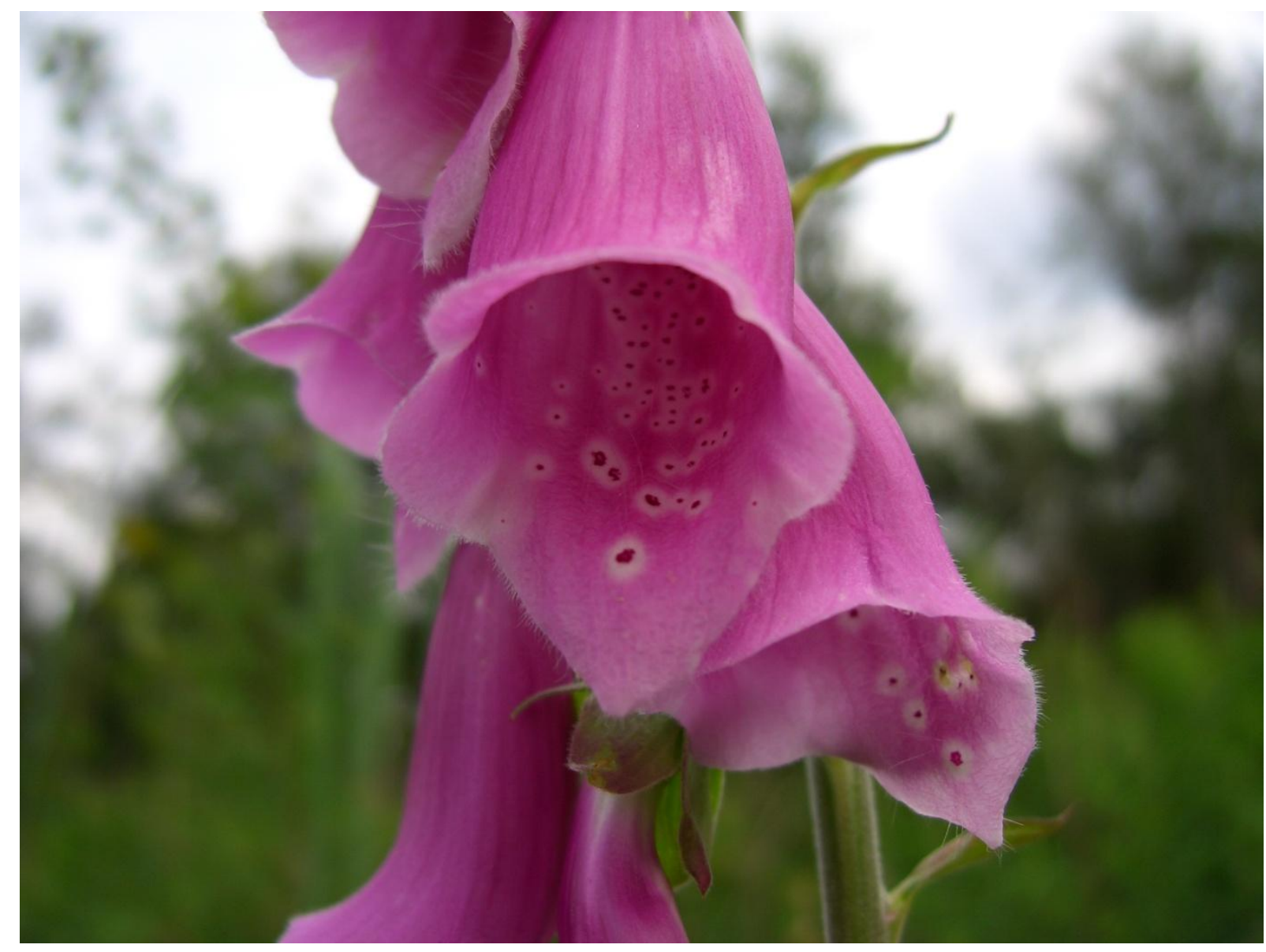


Flowers of Digitalis purpurea. Photograph taken by Steffi Heinrichs. 


\begin{abstract}
The estimation model PhytoCalc allows a non-destructive quantification of dry weight and nutrient pools of understorey plants in forests by using the relationship between species biomass, cover and mean shoot length. The model has been validated with independent samples in several German forest types and can be a useful tool in forest monitoring. However, in open areas within forests (e.g. clear cuts) the current model version underestimates biomass and produces unreliable nutrient pool estimations. Thus, tissue density, as approximated by leaf dry matter content (LDMC), is systematically higher under high light compared to low light conditions. We demonstrate that the ratio of LDMC under clear cut conditions to LDMC under forest conditions can be used to adjust the PhytoCalc-model to clear cut conditions. We investigated the LDMC ratio of five exemplary species commonly occurring on clear cuts. Integrating the square of the ratio as a correction factor improved estimates of biomass to more than $70 \%$ fit between observations and predictions. Results also suggest this ratio can be used to correct nutrient concentrations modelled in PhytoCalc, which tend to be over-estimated in clear cuts. As morphological groups of plant species exhibit significantly different ratios, we advise using group-specific correction factors for clear cut adjustments in the future.
\end{abstract}

\title{
Keywords
}

PhytoCalc, leaf dry matter content (LDMC), nutrient concentration, plant morphological groups

\section{Introduction}

With 1 to $2 \%$ the contribution of the understorey vegetation to aboveground biomass in forest ecosystems is relatively low compared to the tree layer (Bolte et al. 2004, Gilliam 2007). However, as herbaceous plants have up to threefold higher nutrient concentrations than trees, the importance of the understorey vegetation for nutrient cycling is over-proportionate to its biomass (Blank et al. 1980; Yarie 1980; Rodenkirchen 1995; Mrotzek 1998; Bolte et al. 2004; Muller 2003). Its importance even increases in disturbed systems such as clear cuts or windthrows, where the understorey vegetation becomes the most important ecosystem component in terms of primary production and nutrient uptake. Through changes in species composition, nutrient concentration and growth, the understorey vegetation can function as an important 
nutrient sink (Marks and Bormann 1972; Boring et al. 1981; Outcalt and White 1981; Fahey et al. 1991; Mellert et al. 1998, Bartsch 2000). However, the quantification of biomass and nutrient pools is very time-consuming and cost-intensive, as mainly destructive harvesting methods with many replicates are used. Furthermore, this approach cannot be used in protected areas, and is not repeatable on the same plot, making such methods unfeasible for bio-monitoring and permanent plot studies. Nondestructive estimation methods that use relationships between biomass and vegetation cover have been devised for several vegetation types (Siccama et al. 1970; Röttgermann et al. 2000; Muukkonen et al. 2006), but do not regard nutrient pools. Thus, intensive monitoring programs such as the European Level-II-network (Schulze et al. 2000; De Vries et al. 2003; Seidling 2005) have so far considered understorey vegetation only in terms of its indicator quality and contribution to forest biodiversity.

Enhancing an earlier approach by Kellomäki (1974), the PhytoCalc model was developed (Bolte 1999; Bolte et al. 2002, Bolte 2006) to estimate aboveground biomass and nutrient pools of the forest understorey based on cover and mean shoot length of plant species. Data from biomass harvests of 46 widespread species of beech, oak and Scots pine forests of north-eastern Germany and the low mountain ranges provided the basis for this model. Species data were aggregated into 13 morphological growth groups (main groups: herbs, graminoids, ferns, small shrubs, dwarf shrubs, mosses). For each growth group, non-linear regressions were developed to describe the relationship between aboveground biomass, species cover and mean shoot length. In addition, during the model development species were joined to different element groups; these groups are characterized by similar nutrient concentrations within the aboveground plant organs, and consider as well the species morphology, taxonomy and site characteristics. Average nutrient concentrations of each element group were used to predict nutrient pools of plants per area by multiplicatively linking the estimated dry weight and the nutrient concentration.

PhytoCalc has been successfully validated on independent measurements in several German forest ecosystems (Mölder et al. 2008; Schulze et al. 2009). Mölder et al. (2008) found that predicted values differed by less than $10 \%$ from harvested dry weights in Hainich National Park (Thuringia), an area with broad deciduous forests rich in tree species. PhytoCalc is thus suited to measure biomass and nutrient pools of understorey vegetation in forest monitoring (Bolte et al. 2004; BMELV 2006; Bolte 2006; Schulze et al. 2009). 
In disturbed areas with high irradiance levels, the model so far yielded inadequate results. Klinck and Fröhlich (2009) found that PhytoCalc strongly underestimated the aboveground biomass in small clear cuts of Norway spruce stands. This would suggest the establishment of a new model under these open field conditions which would require intensive harvesting operations. A shortcut solution could be the comprehension of tissue density. It is well known that plants in open areas form denser tissues (Meziane and Shipley 1999; Schulze et al. 2002) than in closed forests. Tissue density can be expressed by the leaf dry matter content (LDMC; Garnier and Laurent 1994; Wilson et al. 1999; Westoby et al. 2002), a plant trait easy to measure using only a small number of plant individuals (Cornelissen et al. 2003). In this study we compare LDMC of understorey plant species under closed canopy and in four-year-old clear cuts and demonstrate that the LMDC ratio can be used to correct the results of PhytoCalc in order to achieve reliable aboveground biomass estimations with deviations close to those of the initial PhytoCalc model (Bolte 1999; Schulze et al. 2009). We investigated Agrostis capillaris, Deschampsia flexuosa, Digitalis purpurea, Epilobium angustifolium and Rubus idaeus as five frequent species in Norway spruce forests of Germany, that exhibit increased growth after disturbance. In particular, we focus on the following questions: (1) How reliably does PhytoCalc estimate dry weight, as well as nitrogen, phosphorus and potassium pools in the five species on clear cuts as compared to closed canopy conditions? (2) Can model predictions be improved by using the LDMC ratio as a correction factor under clear cut conditions? (3) Can specific correction factors for morphological plant groups be found?

\section{Material and Methods}

Study site

This study is part of a long-term forest conversion experiment (see Heinrichs and Schmidt 2009) and was carried out on four 1 ha clear cuts and in adjacent Norway spruce forest stands in the Solling hills, a low mountain range (up to $528 \mathrm{~m}$ above sea level) in the north-western part of Central Germany. Two clear cuts each were located at the study sites Otterbach (300 m a.s.l., mean annual precipitation $915 \mathrm{~mm}$, mean annual temperature of $7.8{ }^{\circ} \mathrm{C}$ ) and Neuhaus (509 m, $1029 \mathrm{~mm}, 7.3^{\circ} \mathrm{C}$; Gauer and Aldinger 2005). The Solling is formed of Triassic sandstone covered with loess. Predominant are podzolic brown soils (Dystric Cambisols) with a low base saturation and a good water supply. $\mathrm{C} / \mathrm{N}$ ratios are ca. 20 and the predominant humus form is humimor (Ellenberg et 
al. 1986, Scheffer and Schachtschabel 2002; Table 1). Amelioration liming containing magnesium was applied to both study sites in 1990, at Neuhaus also in 2001.

Table 1 Mean soil parameters ( \pm SE; 0-10 cm mineral soil) and the relative photosynthetic active radiation (PAR) measured above the herb layer on clear cuts and in surrounding closed forests at the study sites Neuhaus and Otterbach in the Solling hills; on each clear cut and forest plot soil values were obtained on four subplots á $100 \mathrm{~m}^{2}$, PAR (in \% of open field conditions) was measured on 20 subplots with LI-190 Quantum Sensors (Licor, Nebraska, USA) on overcast days with diffuse light conditions from July to September 2007; for each study site two clear cuts and four forest plots were available

\begin{tabular}{|c|c|c|c|c|c|c|}
\hline & $\mathrm{pH}$ & $\begin{array}{l}\mathrm{C} / \mathrm{N} \\
\text { ratio }\end{array}$ & $\begin{array}{c}\mathrm{N} \\
{\left[\mathrm{mg} \mathrm{g}^{-1}\right]}\end{array}$ & $\begin{array}{c}\mathrm{P} \\
{\left[\mathrm{mg} \mathrm{g}^{-1}\right]}\end{array}$ & $\begin{array}{c}\mathrm{K} \\
{\left[\mathrm{mg} \mathrm{g}^{-1}\right]}\end{array}$ & $\begin{array}{l}\text { PAR } \\
{[\%]}\end{array}$ \\
\hline \multicolumn{7}{|l|}{ Neuhaus } \\
\hline Clear cut & $\begin{array}{c}3.48 \\
( \pm 0.09)\end{array}$ & $\begin{array}{c}19.16 \\
( \pm 1.05)\end{array}$ & $\begin{array}{c}2.56 \\
( \pm 0.38)\end{array}$ & $\begin{array}{c}0.60 \\
( \pm 0.04)\end{array}$ & $\begin{array}{c}0.06 \\
( \pm 0.01)\end{array}$ & $\begin{array}{c}95.20 \\
( \pm 2.70)\end{array}$ \\
\hline closed forest & $\begin{array}{c}3.37 \\
( \pm 0.08)\end{array}$ & $\begin{array}{c}19.80 \\
( \pm 0.77)\end{array}$ & $\begin{array}{c}2.87 \\
( \pm 0.31)\end{array}$ & $\begin{array}{c}0.62 \\
( \pm 0.04)\end{array}$ & $\begin{array}{c}0.06 \\
( \pm 0.00)\end{array}$ & $\begin{array}{c}11.10 \\
( \pm 1.98)\end{array}$ \\
\hline \multicolumn{7}{|l|}{ Otterbach } \\
\hline Clear cut & $\begin{array}{c}3.51 \\
( \pm 0.07)\end{array}$ & $\begin{array}{c}20.18 \\
( \pm 1.05)\end{array}$ & $\begin{array}{c}1.86 \\
( \pm 0.36)\end{array}$ & $\begin{array}{c}0.37 \\
( \pm 0.04)\end{array}$ & $\begin{array}{c}0.06 \\
( \pm 0.01)\end{array}$ & $\begin{array}{c}88.92 \\
( \pm 3.62)\end{array}$ \\
\hline closed forest & $\begin{array}{c}3.21 \\
( \pm 0.05)\end{array}$ & $\begin{array}{c}20.33 \\
( \pm 0.50)\end{array}$ & $\begin{array}{c}2.10 \\
( \pm 0.29)\end{array}$ & $\begin{array}{c}0.38 \\
( \pm 0.02)\end{array}$ & $\begin{array}{c}0.10 \\
( \pm 0.02)\end{array}$ & $\begin{array}{c}12.86 \\
( \pm 3.34)\end{array}$ \\
\hline
\end{tabular}

The clear cutting was conducted in the autumn of 2003. Four years after clear cutting the plots received ca. $90 \%$ of the photosynthetic active radiation (PAR) above the herb layer, and were, among other species, covered by R. idaeus, E. angustifolium, D. flexuosa and A. capillaris (Heinrichs and Schmidt, 2009; Table 1). The adjacent, around 100-yearold, Norway spruce plantations (Galio harcynici-Culto-Piceetum; Zerbe 1993) with a PAR of around $10 \%$ had an understorey dominated by Dryopteris dilatata, Oxalis acetosella and Vaccinium myrtillus, but A. capillaris and D. flexuosa were also frequent (Table 1).

\section{Vegetation measurements, biomass harvest and nutrient analyses}

Data for D. purpurea and R. idaeus were obtained from Klinck and Fröhlich (2009), a study conducted in the same study area. Data for A. capillaris, D. flexuosa and E. angustifolium were sampled as follows: On the clear cuts, $20 \times 0.25 \mathrm{~m}^{2}$-plots were chosen for the harvest of $A$. capillaris and D. flexuosa. For E. angustifolium, which had higher shoot lengths than the grasses, $20 \times 1 \mathrm{~m}^{2}$-plots were chosen for harvesting (Donita 1972). Plots were selected in order to achieve a wide range of cover values for each species, ranging from below $10 \%$ to more than $95 \%$. In addition, for both grass species, $20 \times 0.25 \mathrm{~m}^{2}$-plots were chosen under closed canopy conditions. On each plot, the species mean shoot length was derived from the measurement of the elongated 
shoot length of 20 randomly chosen individuals. Extremely large or small individuals that did not represent the majority of plants on the plots were omitted, when more than 20 individuals were available, to avoid outlier effects. As D. purpurea was present mostly in flowering stems on all plots, mean shoot length measured on taller flowering individuals was used, to avoid underestimation (Klinck and Fröhlich 2009). Species cover was measured by applying image processing software (Adobe Photoshop CS3 10.0, Adobe Systems Inc.) to perpendicular photographs. The number of screen pixels occupied by a plant species was counted using the magic wand tool and related to the reference area marked by the wooden frame included in each image (Dietz and Steinlein 1996).

From the $28^{\text {th }}$ of June 2007 to the $8^{\text {th }}$ of August 2007 the aboveground biomass was harvested close to the soil surface, oven dried for at least $48 \mathrm{~h}$ at $60^{\circ} \mathrm{C}$, and weighed. For nutrient analyses, an aliquot of the dried material was finely milled and analysed for total nitrogen (N, combustion in Carlo Erba Elemental Analyser), potassium (K, atomic absorption spectrometer) and phosphorus (P, colorimeter, Schlichting et al. 1995), the latter elements extracted by pressure digestion in $65 \%$ nitric acid. Due to the different liming regimes at both study sites, calcium and magnesium were not regarded in this study.

\section{Estimation of LDMC}

Leaf dry matter content (LDMC) was measured following the procedure proposed by Wilson et al. (1999): We calculated the ratio of dry weight divided by saturated wet weight (fresh plant material) on leaf samples from five individuals per species and stand type. In total 15 species were regarded including the five harvested ones, whereby the leaf material was collected independently of biomass harvests. The investigated species were assigned to the following morphological growth groups: Small herbs (Galium saxatile, Maianthemum bifolium, Trientalis europaea), tall herbs (D. purpurea, E. angustifolium), grasses (A. capillaris, Calamagrostis epigejos, D. flexuosa, Holcus mollis), sedges and rushes (Carex pilulifera, Juncus effusus, Luzula luzuloides), small shrubs/dwarf-shrubs (Rubus fruticosus, R. idaeus, V. myrtillus). In general, five leaves per individual were collected (except $M$. bifolium). For the small statured G. saxatile, with thin and small leaves, the whole aboveground plant material was considered. 
For each species the ratio of LDMC under clear cut to LDMC under forest condition was calculated. Out of these species specific ratios a mean ratio per growth group was calculated.

\section{Biomass and nutrient pool estimation with PhytoCalc}

The current calibration of the PhytoCalc model is based on biomass harvests of 46 forest species of Germany's north eastern lowlands and low mountain ranges. As shown in formula (1), the aboveground dry weight ( $\left.D W_{\text {predicted }}\right)$ of a species is modelled as a function of percentage cover (C) and mean shoot length (SL):

$\mathrm{DW}_{\text {predicted }}=\mathrm{a} \mathrm{C}^{\mathrm{b}} \mathrm{SL}^{\mathrm{c}}$

Based on 1700 data records of 46 species, Bolte (2006) fitted regression coefficients a, b and $\mathrm{c}$ for 13 different morphological growth groups. Iteratively the combination of coefficients was determined representing the least residual sum of squares and the highest non-linear coefficient of determination $\left(\mathrm{R}^{2}\right.$; Appendix 2, Table A1).

Based on measured element concentrations, the 46 species were assigned to 11 element groups with similar nutrient concentrations in aboveground organs (Bolte et al. 2002). For each element group average nutrient concentrations were determined $\left(\mathrm{NC}_{\mathrm{EG}}\right)$, which are the basis for nutrient pool estimations (Appendix 2, Table A2). Multiplying these average values by predicted dry weight determined for the constituent species (2) yields an estimate of the standing nutrient pool ( $\left.\mathrm{NP}_{\text {predicted }}\right)$ :

$\mathrm{NP}_{\text {predicted }}=\mathrm{DW}_{\text {predicted }} \mathrm{NC}_{\mathrm{EG}} 10^{-3}$

To compute dry weights and nutrient pools in this study we applied the parameters for the growth groups small grasses (D. flexuosa), middle grasses (A. capillaris), tall herbs (D. purpurea, E. angustifolium) and small shrubs (R. idaeus), and for the element groups nutrient poor grasses (A. capillaris, D. flexuosa), nutrient poor herbs (D. purpurea, E. angustifolium) and Rubus-shrubs (R. idaeus).

\section{PhytoCalc under clear cut situations}

We computed separate regressions of the dependent variable aboveground dry weight of $A$. capillaris and $D$. flexuosa against the independent variables cover and mean shoot 
length in closed Norway spruce forests and on clear cuts, respectively. The influence of shoot length on biomass is adequately modelled by one power function across forests and clear cuts, whereas regressions of species cover against dry weights resulted in quite similar powers (but see D. flexuosa) across stand types but in higher slopes under clear cut conditions (Fig. 1). This implies a poor performance of PhytoCalc with parameters calibrated in forests under clear cut conditions. Thus, the performance was tested by contrasting observed and predicted dry weights.
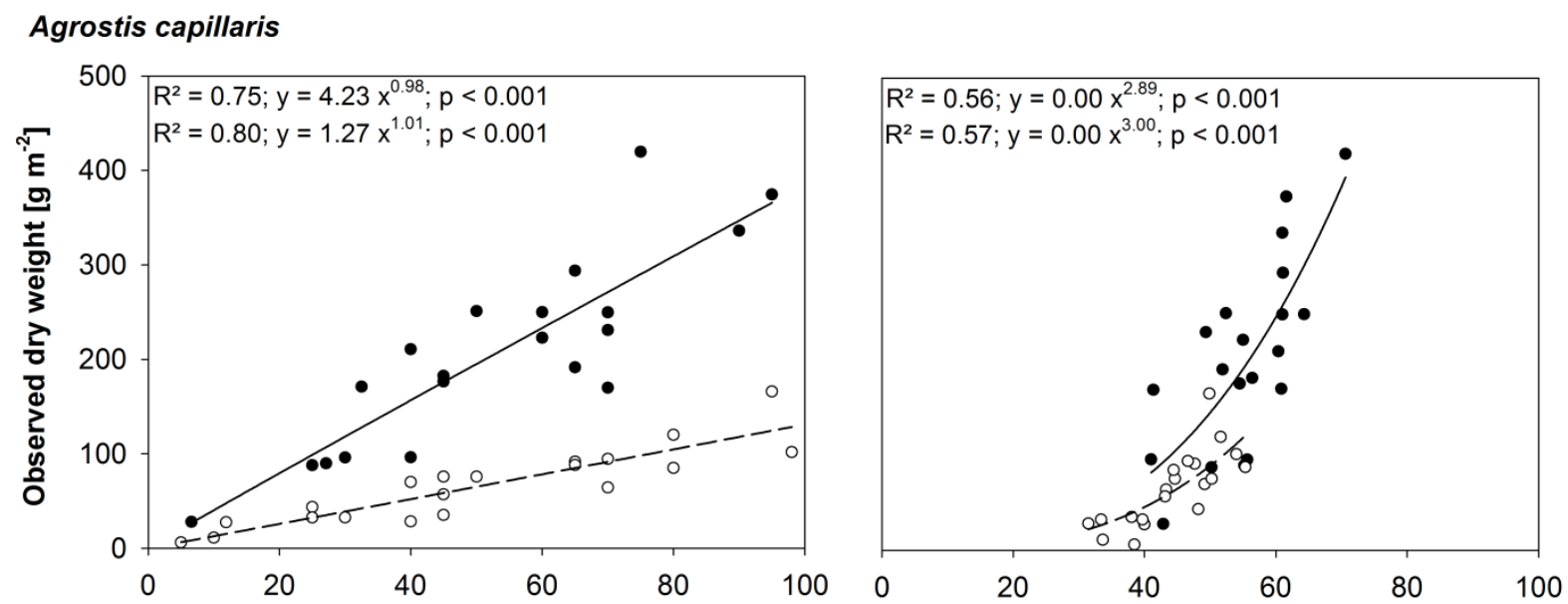

Deschampsia flexuosa
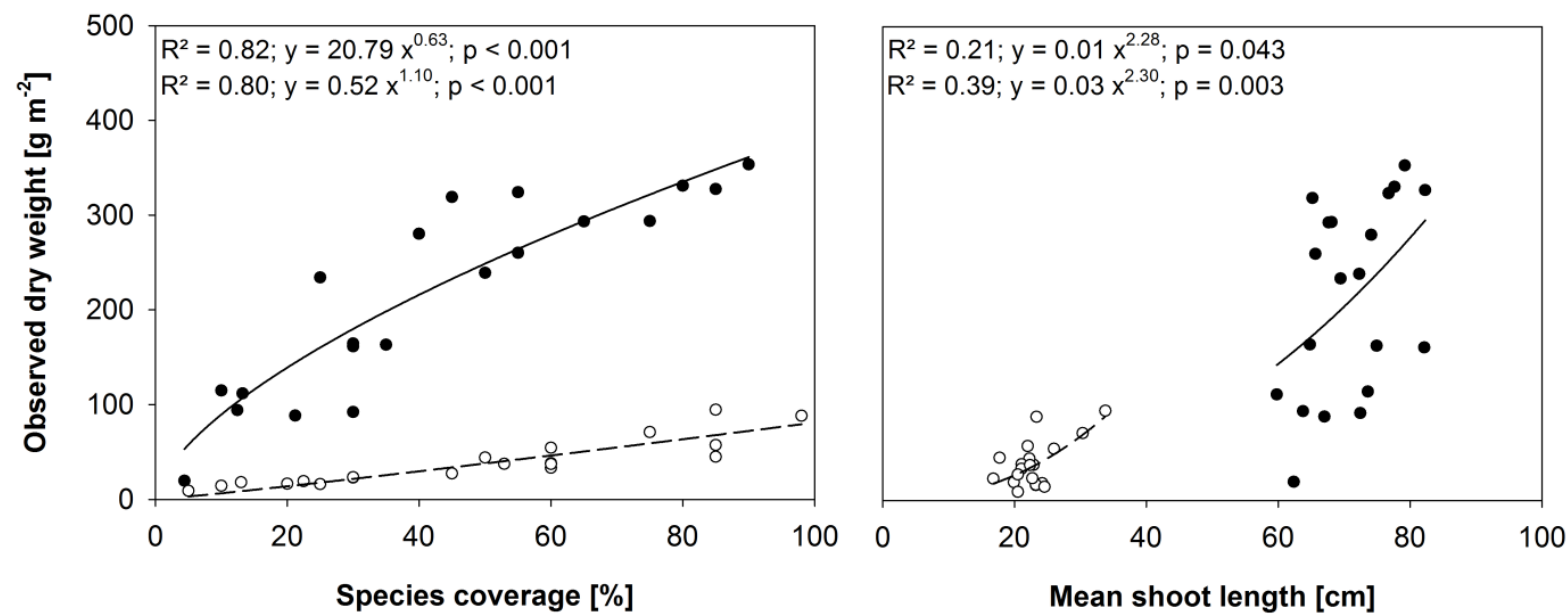

Fig. 1 Bivariate regressions of observed aboveground dry weight against cover and mean shoot length of $A$. capillaris and D. flexuosa sampled on plots in closed Norway spruce forests $(\circ)$ and on clear cuts $(\bullet)$

Above mentioned regressions suggest that the linear integration of one factor, which can account for the steeper relationship between cover and biomass on clear cuts, into PhytoCalc might be sufficient in order to achieve reliable dry weight estimations. Such step could make a refitting of allometric functions used by PhytoCalc unnecessary. Thus, 
the calculated LDMC ratios between clear cut and forest conditions were established as correction factors (CF) for the five species investigated exemplarily (see above).

To optimise the integration of CF in PhytoCalc we multiplicatively linked the CF to equation (1) and performed a non-linear regression, which determined the $\beta$ value that resulted in the least residual sum of squares. A regression coefficient of $\beta=1$ would offer a simple multiplication of $\mathrm{DW}_{\text {predicted }}$ with $\mathrm{CF}$ as shown in formula (3). $A ß \neq 1$ would point to the need for further adaptations of formula (3) to achieve reliable dry weight predictions.

$\mathrm{DW}_{\text {observed }}=\mathrm{a} \mathrm{C}^{\mathrm{b}} \mathrm{SL}^{\mathrm{c}}=\mathrm{DW}_{\text {predicted }} \mathrm{CF}^{\beta}$

According to formula (2) reliable nutrient pool estimations depend, beside reliable dry weight estimations, also on adequate element group concentrations used by PhytoCalc, which should reflect observed nutrient concentrations in the field. Thus, we compared nutrient concentrations observed in closed forests and on clear cuts with nutrient concentrations of the element groups using a one sample t-test. In addition, to analyse if the integration of the CF into nutrient pool estimations would improve estimation results, a non-linear regression using $\mathrm{CF}$ as covariable was calculated between observed and predicted nutrient pools $\left(\mathrm{NP}_{\text {observed }}=\mathrm{NP}_{\text {predicted }} \mathrm{CF}^{\beta}=\mathrm{DW}_{\text {predicted }} \mathrm{NC}_{\mathrm{EG} \text { predicted }} 10^{-3}\right.$ $\mathrm{CF}^{\beta}$ ). A regression coefficient of $B=0$ would make a correction of the used nutrient concentration unnecessary. $A B \neq 0$ would indicate a further correction of the used nutrient concentrations for the different element groups in PhytoCalc.

All observed values and their corresponding predicted values were compared calculating $\mathrm{R}^{2}$ out of the variation around unity, which marks total identity of observed and predicted values.

Differences between group-specific CFs were analysed by the Kruskal-Wallis-test. As the sample size for the growth groups was too small, no post-hoc test was performed.

All statistical analyses were conducted using R 2.8.1 (R Development Core Team 2008). Results were assumed to be significant at $\mathrm{p}<0.05$.

\section{Results}

Influence of the study site

Among the studied species only E. angustifolium had been harvested at both study sites.

The fact that there were no significant differences in nutrient concentrations between 
the sites $(\mathrm{N}: \mathrm{t}=-0.84, \mathrm{p}=0.41 ; \mathrm{P}: \mathrm{t}=1.97 ; \mathrm{p}=0.07 ; \mathrm{K}: \mathrm{t}=2.09, \mathrm{p}=0.06)$ indicates that pooling nutrient measurements was justified.

Performance of PhytoCalc on clear cuts - dry weight

PhytoCalc had been calibrated under closed canopy conditions; consequently the usage of the growth group specific functions resulted in close fits between predicted and observed dry weights in closed forests (middle grass: $A$. capillaris, $\mathrm{R}^{2}=0.79$; small grass: D. flexuosa. $\mathrm{R}^{2}=0.89$ ). The maximum measured dry weights were $94.4 \mathrm{~g} \mathrm{~m}^{-2}$ for $D$. flexuosa and $165.8 \mathrm{~g} \mathrm{~m}^{-2}$ for A. capillaris compared to a maximum estimated value of 78.6 $\mathrm{g} \mathrm{m}^{-2}$ and $139.0 \mathrm{~g} \mathrm{~m}^{-2}$.

In contrast to this, the steeper allometric relations between dry weight and the cover value on clear cuts produced large underestimations of the dry weight when using the same functions for both species (Appendix 2, Table A1, Fig. A1).

For both grass species, as well as for D. purpurea, E. angustifolium and R. idaeus, the LDMC differed significantly between closed canopy and clear cut conditions (Table 2). The ratio between both LDMC-values was therefore derived to function as a correction factor for PhytoCalc-predictions on clear cuts. The CF was lowest for the small shrub $R$. idaeus and highest for D. purpurea and E. angustifolium. The two grass species showed intermediate values.

Table 2 Mean $\mathrm{LDMC}_{\text {clear cut }}$ and mean $\mathrm{LDMC}_{\text {forest }}$ based on five individuals per species and stand type, results of the Student's t-test comparing both values, and the calculated correction factor $(\mathrm{CF})$; $\mathrm{CF}$ was calculated as the ratio of LDMC $_{\text {clear cut }}$ to LDMC forest

\begin{tabular}{lccccc}
\hline & LDMC $_{\text {clear cut }}$ & LDMC forest & $\mathrm{t}$ & $\mathrm{p}$-value & $\mathrm{CF}$ \\
\hline Agrostis capillaris & 0.37 & 0.23 & 10.67 & $<0.001$ & 1.61 \\
Deschampsia flexuosa & 0.37 & 0.24 & 10.39 & $<0.001$ & 1.54 \\
Digitalis purpurea & 0.29 & 0.17 & 6.77 & $<0.001$ & 1.71 \\
Epilobium angustifolium & 0.35 & 0.15 & 20.42 & $<0.001$ & 2.33 \\
Rubus idaeus & 0.46 & 0.34 & 7.10 & $<0.001$ & 1.35 \\
\hline
\end{tabular}

Regression analyses of observed against predicted dry weights using the CF as covariable resulted in coefficients $\beta$ differing all significantly from 0 , and ranging from 1.78 for E. angustifolium to 2.48 for D. flexuosa (Table 3). This indicated to include the CFs in its quadratic term into PhytoCalc by a simple multiplication when used on clear cuts. 
Table 3 Estimated $ß$ coefficients, their standard error (SE) and p-value from non linear regressions of observed against predicted dry weights on clear cuts using the CF as a covariable based on 20 studied plots per species

\begin{tabular}{lcrc}
\hline & $\beta$ & SE & p-value \\
\hline Agrostis capillaris & 1.96 & 0.08 & $<0.001$ \\
Deschampsia flexuosa & 2.48 & 0.18 & $<0.001$ \\
Digitalis purpurea & 2.42 & 0.11 & $<0.001$ \\
Epilobium angustifolium & 1.78 & 0.07 & $<0.001$ \\
Rubus idaeus & 2.40 & 0.18 & $<0.001$ \\
\hline
\end{tabular}

Such CF integration resulted in significant determination coefficients of 0.63 for $D$. purpurea to 0.89 for $R$. idaeus when contrasting observed and predicted dry weight values and brought the regression slope of each species close to unity, whereas the usage of uncorrected values did not allow the calculation of determination coefficients around unity in most cases (Table 4, Fig. 2 a vs. b).

Table 4 Coefficients of determination resulting from contrasting observed dry weights with either uncorrected predicted values obtained from PhytoCalc or with predicted values corrected by multiplication with $\mathrm{CF}^{2}$. The morphological group to which each species is assigned to indicates the applied regression function according to Table A1, Appendix $2,{ }^{* * *}$ indicates $\mathrm{p} \leq 0.001,{ }^{* *}$ indicates $\mathrm{p} \leq 0.01,{ }^{*}$ indicates $\mathrm{p} \leq 0.05, \mathrm{n}=20$ plots per species

\begin{tabular}{llll}
\hline & Morphological & \multicolumn{2}{c}{ Predicted dry weight } \\
\cline { 3 - 3 } & group & Uncorrected & Corrected with CF $^{2}$ \\
\hline Agrostis capillaris & Middle grass & 0.00 & $0.88^{* * *}$ \\
Deschampsia flexuosa & Small grass & 0.00 & $0.93^{* * *}$ \\
Digitalis purpurea & Tall herb & 0.00 & $0.63^{* * *}$ \\
Epilobium angustifolium & Tall herb & 0.00 & $0.76^{* * *}$ \\
Rubus idaeus & Small shrub & $0.35^{* *}$ & $0.89^{* * *}$ \\
\hline
\end{tabular}

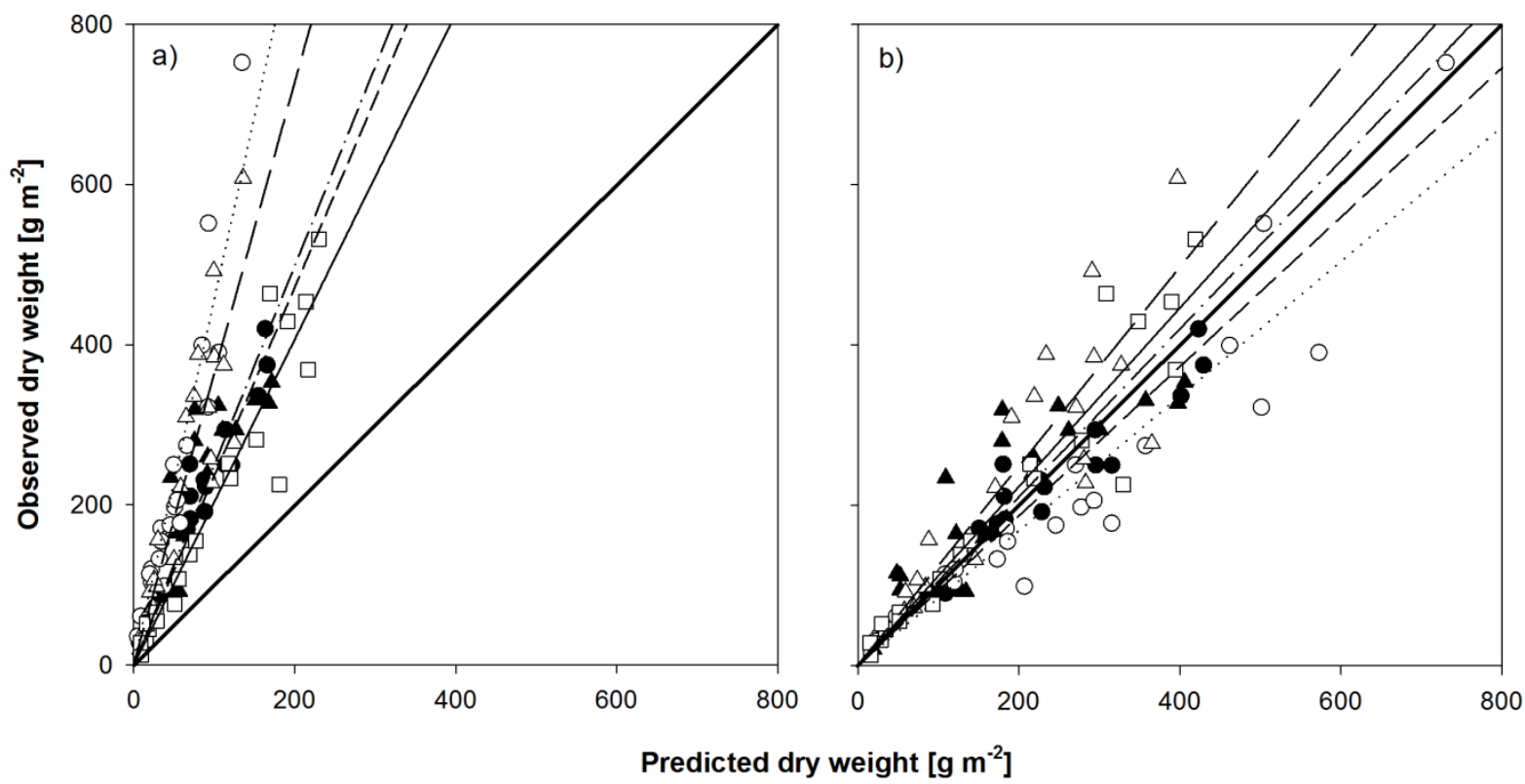

Fig. 2 Modelled vs. observed dry weights on clear cuts for $(\bullet)$ A. capillaris, $(\mathbf{\Delta})$ D. flexuosa, $(\Delta)$ D. purpurea, $(\circ)$ E. angustifolium and ( $\square$ ) R. idaeus; a) using the uncorrected Phytocalc model b) using the model corrected by multiplication with $\mathrm{CF}^{2}$; Regression lines are given for each species (A. capillaris: short dash; D. flexuosa: dash dot; $D$. purpurea: long dash; E. angustifolium: dotted; R. idaeus: solid line). The thick solid line represents unity; the degree of tilting from unity in a) is proportional to LDMC ratios (A. capillaris: 1.61 ; D. flexuosa: 1.54 ; D. purpurea: 1.71 ; E. angustifolium: 2.33; R. idaeus: 1.35); $\mathrm{R}^{2}$ values out of the variation around unity are given in Table 4 
Considering all species together, a comparison between predicted dry weights corrected using $\mathrm{CF}^{2}$ and observed dry weights resulted in a significant $\mathrm{R}^{2}$ of 0.77 . The linear regression equation of this comparison forced through the origin was $\mathrm{DW}_{\text {observed }}=0.995$ $\mathrm{DW}_{\text {predicted }}$ with a residual standard error of 0.027 . The slope was not significantly different from unity $(\mathrm{t}=-0.180, \mathrm{p}=0.857)$.
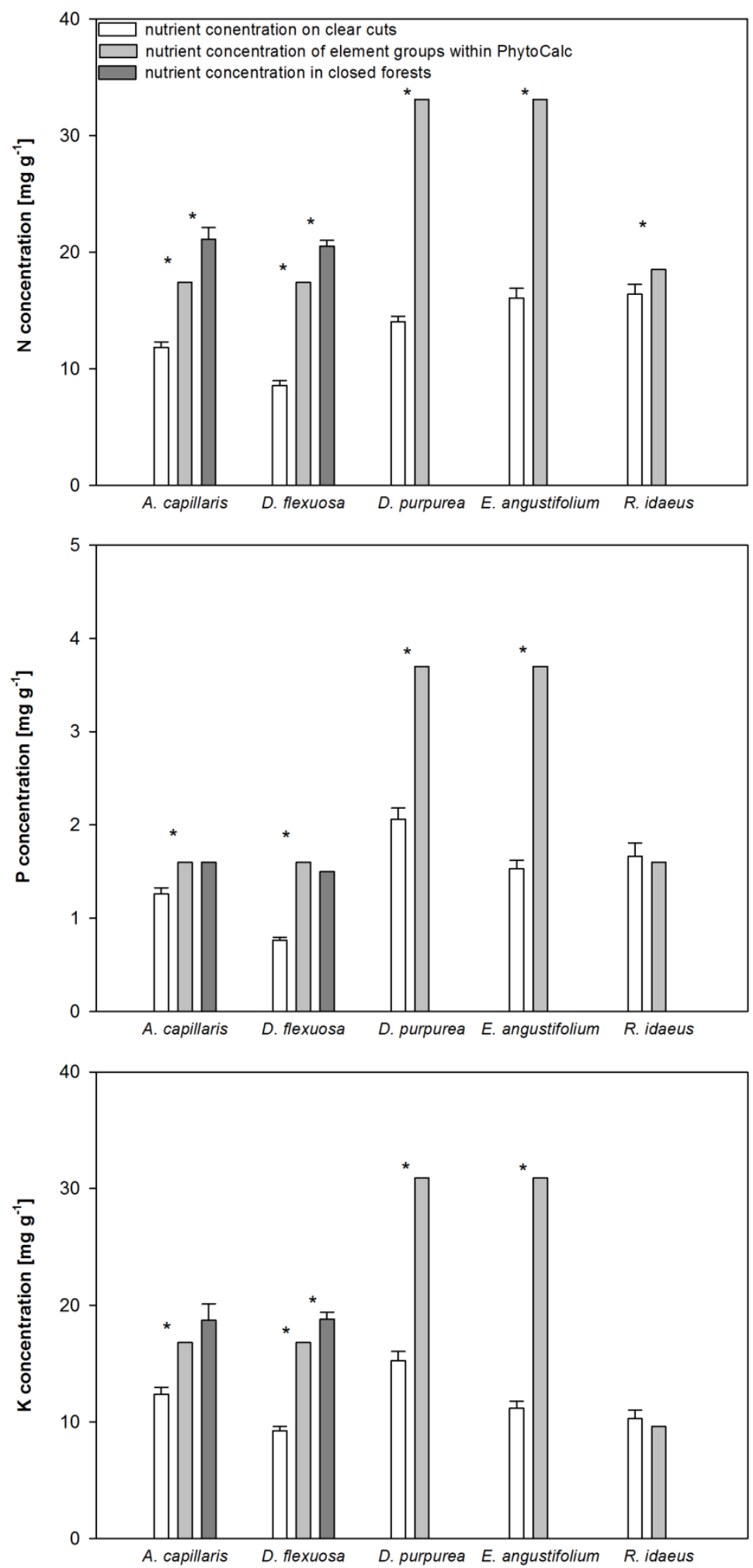

Fig. 3 Observed nutrient concentrations in closed Norway spruce stands for $A$. capillaris and D. flexuosa and on clear cuts for both grasses, D. purpurea, $E$. angustifolium and R. idaeus in comparison to element group concentrations applied by PhytoCalc for these species; * indicates significant differences between observed nutrient concentration determined on 20 plots and element group concentration based on one-sample t-test; observe the different vertical axis scale for the $P$ concentration 


\section{Performance of PhytoCalc on clear cuts - nutrient pools}

Beside adequately predicted dry weights, reliable nutrient concentrations of element groups used within PhytoCalc are necessary for nutrient pool predictions. N concentrations of $A$. capillaris and $D$. flexuosa observed under closed canopy were higher than the according element group concentration. For D. flexuosa this was also the case for K (Fig. 3). However, determination coefficients, when contrasting observed nutrient pools and predicted nutrient pools, were all significant and ranged from 0.66 for the nitrogen pool of $A$. capillaris to 0.82 for the phosphorus pool of $D$. flexuosa (Table 5).

Table 5 Coefficients of determination of the comparisons of observed against predicted nutrient pools under closed forests and on clear cuts for each species. For the prediction on clear cuts either the uncorrected nutrient concentrations implemented within PhytoCalc or the same nutrient concentrations corrected by multiplication with $\mathrm{CF}^{-1}$ were used. The assignment of the species to the element group indicates, which concentrations were used for prediction according to Table A2, Appendix 2, ${ }^{* * *}$ indicates $\mathrm{p} \leq 0.001,{ }^{* *}$ indicates $\mathrm{p} \leq 0.01$, ${ }^{*}$ indicates $\mathrm{p} \leq 0.05$, n.d. $=$ not defined, $\mathrm{n}=20$ plots per species.

\begin{tabular}{|c|c|c|c|c|c|c|c|}
\hline \multirow{2}{*}{$\begin{array}{l}\text { Nutrient concentration } \\
\text { within PhytoCalc }\end{array}$} & \multirow[t]{2}{*}{ Element group } & \multicolumn{3}{|c|}{ Closed forest } & \multicolumn{3}{|c|}{ Clear cut } \\
\hline & & $\overline{\mathrm{N}}$ & $P$ & $\mathrm{~K}$ & $\overline{\mathrm{N}}$ & $P$ & $\mathrm{~K}$ \\
\hline Agrostis capillaris & Nutrient poor grass & & & & & & \\
\hline Uncorrected & & $0.66^{* * *}$ & $0.81^{* * *}$ & $0.72^{* * *}$ & 0.00 & $0.62^{* * *}$ & $0.37^{* *}$ \\
\hline Corrected & & n.d. & n.d. & n.d & $0.88^{* * *}$ & $0.67^{* * *}$ & $0.76^{* * *}$ \\
\hline Deschampsia flexuosa & Nutrient poor grass & & & & & & \\
\hline Uncorreted & & $0.75^{* * *}$ & $0.82^{* * *}$ & $0.79^{* * *}$ & 0.00 & 0.00 & 0.00 \\
\hline Corrected & & n.d. & n.d. & n.d. & $0.31^{*}$ & 0.00 & $0.44^{* *}$ \\
\hline Epilobium angustifolium & Nutrient poor herb & & & & & & \\
\hline Uncorrected & & n.d. & n.d. & n.d. & 0.00 & 0.00 & 0.00 \\
\hline Corrected & & n.d. & n.d. & n.d. & $0.75^{* * *}$ & $0.77^{* * *}$ & $0.48^{* *}$ \\
\hline Digitalis purpurea & Nutrient poor herb & & & & & & \\
\hline Uncorrected & & n.d. & n.d. & n.d. & 0.00 & 0.17 & 0.00 \\
\hline Corrected & & n.d. & n.d. & n.d. & $0.65^{* * *}$ & $0.58^{* * *}$ & $0.70^{* * *}$ \\
\hline Rubus idaeus & Rubus shrub & & & & & & \\
\hline Uncorrected & & n.d. & n.d. & n.d. & $0.84^{* * *}$ & $0.84^{* * *}$ & $0.96^{* * *}$ \\
\hline Corrected & & n.d. & n.d. & n.d. & $0.80^{* * *}$ & $0.64^{* * *}$ & $0.91^{* * *}$ \\
\hline
\end{tabular}

On clear cuts though, nutrient concentrations of harvested plants were significantly lower for all species (except for the K- and P-concentrations of Rubus idaeus) than PhytoCalc concentrations (Fig. 3). Consequently, when contrasting observations and predictions, determination coefficients were low in most cases (Table 5). A regression analysis of observed against predicted nutrient pools using the $\mathrm{CF}$ as covariable resulted in $ß$ coefficients significantly different from 0 for A. capillaris, D. flexuosa, D. purpurea, and E. angustifolium (Table 6). The results indicate to correct the nutrient concentration implemented within PhytoCalc by multiplication with $\mathrm{CF}^{-1}$. This correction resulted in higher determination coefficients for all species (except $R$. idaeus) than the usage of uncorrected concentrations (Table 5). The determination coefficients ranged from 0.65 
to 0.88 for N, 0.48 to 0.80 for K, and 0.58 to 0.77 for P. D. flexuosa, however, showed lower values.

Table 6 Estimated $ß$ coefficients, their standard error (SE) and p-value from non-linear regressions of observed against predicted nutrient pools using the $\mathrm{CF}$ as a covariable, $\mathrm{n}=20$ plots per species

\begin{tabular}{|c|c|c|c|c|c|c|c|c|c|}
\hline & \multicolumn{3}{|c|}{$\mathrm{N}$} & \multicolumn{3}{|c|}{$\mathrm{P}$} & \multicolumn{3}{|c|}{$\mathrm{K}$} \\
\hline & $\beta$ & SE & $\mathrm{p}$ & $\beta$ & SE & $\mathrm{p}$ & $\beta$ & SE & $\mathrm{p}$ \\
\hline Agrostis capillaris & -0.880 & 0.085 & $<0.001$ & -0.593 & 0.118 & $<0.001$ & -0.727 & 0.122 & $<0.001$ \\
\hline Deschampsia flexuоsa & -1.205 & 0.179 & $<0.001$ & -1.275 & 0.204 & $<0.001$ & -0.940 & 0.191 & $<0.001$ \\
\hline Digitalis purpurea & -1.194 & 0.130 & $<0.001$ & -0.735 & 0.142 & $<0.001$ & -0.946 & 0.131 & $<0.001$ \\
\hline Epilobium angustifolium & -1.099 & 0.086 & $<0.001$ & -1.298 & 0.077 & $<0.001$ & -1.449 & 0.068 & $<0.001$ \\
\hline Rubus idaeus & -0.084 & 0.209 & 0.693 & 0.339 & 0.245 & 0.183 & -0.188 & 0.236 & 0.436 \\
\hline
\end{tabular}

\section{Morphological group specific correction factors}

Table 7 Leaf dry matter content of understorey species on clear cuts and in closed forests assigned to different morphological groups and the calculated species specific and morphological group specific correction factors, LDMC values are based on five individuals per species

\begin{tabular}{|c|c|c|c|}
\hline & Clear cut & forest & $\mathrm{CF}$ \\
\hline \multicolumn{4}{|l|}{ Small herbs } \\
\hline Galium saxatile & 0.25 & 0.22 & 1.14 \\
\hline Maianthemum bifolium & 0.28 & 0.24 & 1.17 \\
\hline Trientalis europea & 0.34 & 0.24 & 1.42 \\
\hline growth group & & & 1.24 \\
\hline \multicolumn{4}{|l|}{ Tall herbs } \\
\hline Digitalis purpurea & 0.29 & 0.17 & 1.71 \\
\hline Epilobium angustifolium & 0.35 & 0.15 & 2.33 \\
\hline growth group & & & 2.02 \\
\hline \multicolumn{4}{|l|}{ Poaceae } \\
\hline Calamagrostis epigejos & 0.47 & 0.34 & 1.38 \\
\hline Holcus mollis & 0.42 & 0.23 & 1.83 \\
\hline Agrostis capillaris & 0.37 & 0.23 & 1.61 \\
\hline Deschampsia flexuosa & 0.37 & 0.24 & 1.54 \\
\hline growth group & & & 1.59 \\
\hline \multicolumn{4}{|l|}{ Cyperaceae/Juncaceae } \\
\hline Carex pilulifera & 0.45 & 0.39 & 1.15 \\
\hline Juncus effusus & 0.41 & 0.32 & 1.28 \\
\hline Luzula luzuloides & 0.40 & 0.34 & 1.18 \\
\hline growth group & & & 1.20 \\
\hline \multicolumn{4}{|l|}{ Small shrubs/dwarf-shrubs } \\
\hline Rubus fruticosus & 0.44 & 0.35 & 1.26 \\
\hline Rubus idaeus & 0.46 & 0.34 & 1.35 \\
\hline Vaccinium myrtillus & 0.46 & 0.35 & 1.31 \\
\hline growth group & & & 1.31 \\
\hline
\end{tabular}

The tall herbs, D. purpurea and $E$. angustifolium, disclosed in general larger differences between observed nutrient concentrations and element group concentrations than the other species (Fig. 3). This is in accordance with the highest CF found for the growth group of tall herbs. Small herbs, as well as sedges and rushes showed the smallest values, whilst the group of small and dwarf shrubs depicted an intermediate value (Table 7). The importance of growth group specific CFs was verified by the Kruskal-Wallis-test $\left(\mathrm{Chi}^{2}=10.38, \mathrm{df}=4, \quad \mathrm{p}\right.$-value $=$ 0.034), which showed a significant difference between growth groups despite the small sample size. 


\section{Discussion}

PhytoCalc performance under closed canopy conditions

In closed Norway spruce forests of the Solling the model PhytoCalc estimated reliable aboveground dry weights for A. capillaris and D. flexuosa, consistent with results of Höhne (1962), Höhne et al. (1981) and Bolte (1999) in temperate coniferous and deciduous forests. A good fit was also found when contrasting observed and predicted N, $\mathrm{P}$, and $\mathrm{K}$ pools, although observed $\mathrm{N}$ and $\mathrm{K}$ concentrations were higher than concentrations applied by PhytoCalc. A. capillaris and D. flexuosa are typical species of infertile sites with low nitrogen concentrations (1-2\% N) compared to other grasses colonizing more nutrient rich sites (e.g. Brachypodium sylvaticum, Melica uniflora: 2.5$3.3 \% \mathrm{~N}$ ) or compared to herbs having in general higher nutrient concentrations (Höhne 1962). In the Solling though, the soils show a better nitrogen supply than soils in Germany's north-east, where the main part of datasets used for the PhytoCalc calibration was sampled. This is to some extent caused by higher nitrogen depositions in the Solling compared to north-east Germany (Gauger et al. 2001). Nevertheless, the measured concentrations are in accordance with other studies (Höhne 1962, Höhne 1963, Bennert 1980, Chapin 1980, Höhne et al. 1981). In general, nutrient concentrations of species are species traits (however, traits with a relative high plasticity), leading to higher differences in nutrient storage between different species or species groups than between sites (Höhne 1962, Thompson et al. 1997).

\section{Performance of PhytoCalc on clear cuts - dry weight}

Although PhytoCalc worked well under a closed Norway spruce canopy, it gave inadequate results on small scale clear cuts for all analysed species as already shown by Klinck and Fröhlich (2009). The application of a simple linear transformation by using the presented LDMC ratio as a correction factor resulted in predicted dry weights of $A$. capillaris, D. flexuosa, D. purpurea, E. angustifolium and R. idaeus that explained $62 \%$ to $93 \%$ of the variance of observations. These predictions were consistent with biomass values found by different authors under high light availability for these species (van Andel 1975; Al-Mufti et al. 1977; van Baalen and Prins 1983; Fahey et al. 1991). Differences in biomass or growth performance under different light regimes have been reported before for D. flexuosa (Scurfield 1954), D. purpurea (van Baalen and Prins 1983), E. angustifolium (Myerscough 1980) and R. idaeus (Ricard and Messier 1996), with all species showing maximum dry weights on open sites. This can be explained by a 
change in the leaf anatomy, as shown for the plasticity of LDMC: plants growing under high irradiance generally have a dense vascular system and a dense, often multilayered, mesophyll, leading to higher leaf dry weights compared to plants of the same species growing in shady conditions (Larcher 2001, Ricard and Messier 1996, Myerscough 1980). Menziane and Shipley (1999) and Shipley (2000) also showed that leaf traits of several species change uniformly with irradiance: lamina and mesophyll thicknesses increased with light availability, whereas the leaf water content decreased. Garnier and Laurent (1994) presented a negative correlation of the leaf water content with the cross-sectional area occupied by vascular tissues and sclerenchyma, which increases with irradiance.

Other factors resulting in a larger dry weight under high irradiance can be a higher density of stems but with leaves covering a smaller area, a larger degree of overlaying vegetation components, or thicker stems, especially for species like D. purpurea. Compared to these factors though, which can differ for each study plot or only account for distinct species groups, the LDMC can be easily recorded for a larger area by sampling leaves from 5 to 10 individuals (Cornelissen et al. 2003) under the different light regimes. The difference in this plant trait can then be a successful correction tool for differences in density and quality of the plant tissue and consequently, the aboveground dry weight with varying environmental conditions, as shown in this study.

\section{PhytoCalc performance on clear cuts - nutrient pools}

Nutrient concentrations on clear cuts were lower than average element group concentrations used by PhytoCalc. This is in accordance with differences detected by Fahey et al. (1991) for A. capillaris and D. flexuosa, and by Högbom and Högberg (1991) and Palviainen et al. (2005) for D. flexuosa comparing clear cuts and closed forests.

As already mentioned above, under open site conditions leaf structure may change: high light availability increases leaf sclerophylly, which is negatively correlated with nutrient concentrations (Loveless 1961, Garnier and Laurent 1994). Furthermore, on clear cuts, plants invest more into stems; the proportion of leaves on the dry weight decreases (Scurfield 1954, van Baalen and Prins 1983). Compared to other plant organs, though, leaves store the largest amount of nutrients (mainly N, P, Ca, Mg, S; Höhne 1962, van Andel and Jager 1981, Larcher 2001). Consequently, also the nutrient concentrations used by PhytoCalc had to be adjusted to clear cut conditions. Non-linear regressions showed that the inverse of the correction factor, proposed in this study, is suited to 
adjust the nutrient concentration. This factor accounted for the reduced nutrient concentration due to a larger degree of sclerenchymatic tissue within leaves under high irradiance compared to low light values. However, for some species, especially $D$. flexuosa, this correction is not sufficient as predictions explained no variance of observations for $\mathrm{P}$ and only 31 and $44 \%$ for $\mathrm{N}$ and $\mathrm{K}$ respectively. For this species the discrepancy regarding the existence of flowering stems between closed forest conditions and clear cuts is extremely severe (Scurfield 1954).

Besides the higher sclerophylly of leaves, other factors can as well account for lower nutrient concentrations and thus for the still unexplained variance of observed nutrient pools by corrected predictions: On clear cuts, stems can already show indications of lignification compared to forest conditions. $\mathrm{K}$ is preferentially stored in flowers and fruits, and not impoverished in stems; however, the leaching of this highly soluble element, due to higher amounts of rainfall reaching the plants on clear cuts, seems to be more important (Höhne 1962, Morton 1977, Larcher 2001). Furthermore, most of these species are growth-limited due to the low light availability under a closed canopy (Scurfield 1954; van Andel 1975; Al-Mufti et al. 1977; van Baalen and Prins 1983; Strengbom et al. 2004). Thus, under clear cut conditions growth is largely enhanced, although the amount of available nutrients might not increase at the same rate, despite a faster mineralisation after clear cutting. The consequence is a "dilution-effect" within the plant biomass (Larcher 2001) characterized by a negative correlation between the nutrient concentration and the aboveground biomass as found by Mellert et al. (1998) and Steiner et al. (1998). The fact that forest residues were removed on the Solling plots after clear cutting, avoiding further release of nutrients from decomposing branches (Stevens and Hornung 1990), contributes as well to the "dilution-effect". Within $R$. idaeus though, nutrient concentrations showed almost no difference between observations on clear cuts and concentrations of the corresponding element group. Ricard and Messier (1996) found no relative increase in stem compared to leaf biomass with increasing light intensity. Furthermore, woody species in general show a slower growth rate. The dwarf-shrub species $V$. myrtillus, for example, also showed constant nutrient concentrations when comparing clear cut and forest conditions (Atlegrim and Sjöberg 1996; Palviainen et al. 2005). Thus, the plasticity of species under different environmental conditions seems to depend on specific morphological characteristics. Also CFs calculated for different morphological groups in this study were significantly different from each other. One explanation for the differences between these growth 
groups is generally that small plants grow in the shadow of taller ones; this is also true on clear cuts. Taller herbs, instead, are totally exposed to sun light. Grasses can dominate clear cuts and are therefore also found under full sunlight. Rushes and sedges have tougher leaves with a high sclerenchymatic content, even under forest conditions, explaining the smaller differences in LDMC between environmental conditions. The same is true for dwarf-shrubs and small shrubs. Thus, it might be reasonable in the future to include one correction factor for each morphological growth group into PhytoCalc to apply this model to clear cut conditions. Thereby, some growth groups chosen in the present study differed from morphological growth groups used by Bolte (1999, 2006): we have considered all woody species together, but grasses and rushes/sedges were considered separately because of their differences in leaf physiology. However, the consideration of more species may lead to a finer differentiation than presently available.

\section{Conclusions}

PhytoCalc is an applicable model for estimating dry weight and nutrient pools of Central European forest communities. By integrating the variability of the easy determinable LDMC under different irradiance regimes as a linear correction factor, the model is also usable in open areas such as larger areas of windthrow or clear cuts. These are expected to occur more frequently in the future due to severe winter storms or during the conversion of Norway spruce stands into mixed stands. On open sites, LDMC accounts for a higher tissue density within species, as well as for lower nutrient concentrations compared to forest conditions, a consequence of the higher sclerophylly of leaves under high irradiance. Different morphological groups showed significantly different CFs, which suggests to integrate one correction factor per morphological group into PhytoCalc to adjust for open site conditions. The group specific ratios detected here are however, only based on a few number of species that were frequent at the Solling sites. Thus, a further integration of species being more frequent in other forest types is necessary as well as the integration of other study sites and forest types to achieve a standard correction factor that is generally applicable on clear cuts. Nevertheless, particular attention should be paid to species known to be able to become dominant during secondary succession after clear cut or windthrow as they will account for most of the biomass then. 
However, here only the extremes (closed canopy vs. full light availability) have been analysed and the results cannot be transferred to situations in highly thinned forest stands, in forest gaps, at forest edges, or on clear cuts where regenerating trees expand rapidly. Therefore, the reaction of plants to different levels of irradiance should be analysed along a gradient from low to high light availability. Thus, threshold values of light availability can be identified which indicate the necessity of a correction of estimated values. In addition, a regression function could be used as a correction factor emanating from plant reactions dependent on light availability.

\section{Acknowledgments}

We would like to thank Andrea Bauer, Martina Knaust, Andreas Parth, Heiko Rubbert and Theresa Waldmann for help with the field and laboratory work, Ruth Gilbert for language correction and Andreas Bolte, one anonymous reviewer and Christian Ammer as subject editor for helpful comments on the manuscript.

\section{References}

Al-Mufti MM, Sydes CL, Furness SB, Grime JP, Band SR (1977) A quantitative analysis of shoot phenology and dominance in herbaceous vegetation. J Ecol 65: 759-791

Altegrim 0, Sjöberg K (1996) Response of bilberry to clear-cutting and single-tree selection harvests in uneven-aged boreal Picea abies forests. Forest Ecol Manage 86: 39-50.

Bartsch N (2000) Element release in beech (Fagus sylvatica L.) forest gaps. Water Air Soil Poll 122: 3-16

Bennert HW (1980) Über die stoffliche Zusammensetzung von Waldbodenpflanzen eines montanen Hainsimsen-Buchenwaldes I. Asche-, Stickstoff- und Proteingehalt. Flora 170: 433-455

Blank JL, Olson RK, Vitousek PM (1980) Nutrient uptake by a diverse spring ephemeral community. Oecologia 47: 96-98

BMELV (Bundesministerium für Ernährung, Landwirtschaft und Verbraucherschutz) (2006) Arbeitsanleitung zur zweiten bundesweiten Bodenzustandserhebung im Wald (BZE II). Bonn

Bolte A (1999) Abschätzung von Trockensubstanz-, Kohlenstoff- und Nährelementvorräten der Waldbodenflora - Verfahren, Anwendung und Schätztafeln. Forstwiss Beitr Tharandt 7, 129pp 
Bolte A (2006) Biomasse- und Elementvorräte der Bodenvegetation auf Flächen des forstlichen Umweltmonitorings in Rheinland-Pfalz (BZE, EU Level II). Ber Forschungszentr Waldökosyst, Reihe B, Bd. 72, 80pp

Bolte A, Anders S, Roloff A (2002) Schätzmodelle zum oberirdischen Vorrat der Waldbodenflora an Trockensubstanz, Kohlenstoff und Makronährelementen. Allg Forst Jagdztg 173: 57-66

Bolte A, Lambertz B, Steinmeyer A, Kallweit R, Meesenburg H (2004) Zur Funktion der Bodenvegetation im Nährstoffhaushalt von Wäldern - Studien auf Dauerbeobachtungsflächen des EU Level II-Programms in Norddeutschland. Forstarchiv 75: 207-220

Boring LR, Monk CD, Swank WT (1981) Early regeneration of a clear-cut southern Appalachian forest. Ecology 62: 1244-1253

Chapin SF III (1980) The mineral nutrition of wild plants. Annu Rev Ecol Syst 11: 233260

Cornelissen JHC, Lavorel S, Garnier E, Díaz S, Buchmann N, Gurvich DE, Reich PB, ter Steege H, Morgan HD, van der Heijden MAG, Pausas JG, Poorter H (2003) A handbook of protocols for standardised and easy measurement of plant functional traits worldwide. Aust J Bot 51: 335-380

De Vries W, Vel E, Reinds GJ, Deelstra H, Klap JM, Leeters EEJM, Hendriks CMA, Kerkvoorden M, Landmann G, Herkendell J, Haussmann T, Erisman JW (2003) Intensive monitoring of forest ecosystems in Europe 1. Objectives, set-up and evaluation strategy. Forest Ecol Manage 174: 77-95

Dietz H, Steinlein T (1996) Determination of plant species cover by means of image analysis. J Veg Sci 7: 131-136

Donita N (1972) Zahl und Größe der Probeflächen bei der direkten Bestimmung der Krautschicht-Biomasse im Walde. Oecol Plant 7: 85-94

Ellenberg H, Mayer R, Schauermann J (1986) Ökosystemforschung - Ergebnisse des Sollingprojekts. Ulmer, Stuttgart

Fahey TJ, Hill MO, Stevens PA, Hornung M, Rowland P (1991) Nutrient accumulation in vegetation following conventional and whole-tree harvest of Sitka spruce plantations in North Wales. Forestry 64: 271-288

Garnier E, Laurent G (1994) Leaf anatomy, specific mass and water content in congeneric annual and perennial grass species. New Phytol 128: 725-736 
Gauer J, Aldinger E (2005) Waldökologische Naturräume Deutschlands - Forstliche Wuchsgebiete und Wuchsbezirke - mit Karte 1:1.000.000. Mitt Ver Forstl Standortskde Forstpflanzenz 43, 324pp

Gauger T, Köble R, Spranger T, Bleeker A, Draaijers G (2001) Deposition loads of sulphur and nitrogen in Germany. Water Air Soil Poll: Focus 1: 353-373

Gilliam FS (2007) The ecological significance of the herbaceous layer in temperate forest ecosystems. Bioscience 57: 845-858

Heinrichs S, Schmidt W (2009) Short-term effects of selection and clear cutting on the shrub and herb layer vegetation during the conversion of even-aged Norway spruce stands into mixed stands. Forest Ecol Manage 258: 667-678

Högbom L, Högberg P (1991) Nitrate nutrition of Deschampsia flexuosa (L.) Trin. in relation to nitrogen deposition in Sweden. Oecologia 87: 488-494

Höhne H (1962) Vergleichende Untersuchungen über Mineralstoff- und Stickstoffgehalt sowie Trockensubstanzproduktion von Waldbodenpflanzen. Arch Forstwes 11: 1085-1141

Höhne H (1963) Der Mineralstoff- und Stickstoffgehalt von Waldbodenpflanzen in Abhängigkeit vom Standort. Arch Forstwes 12: 791-805

Höhne H, Fiedler HJ, Ilgen G (1981) Untersuchungen über den Mineralstoffgehalt von Deschampsia flexuosa (L.) P.B. als Bestandteil von Fichtenforst-Ökosystemen. Flora 171: 199-215

Kellomäki S (1974) Metsän aluskasvillisuuden biomassan ja peittävyyden välisestä suhteesta (On the relation between biomass and coverage in ground vegetation of forest stands). Silva Fenn 8: 20-46

Klinck U, Fröhlich D (2009) Application of the phytomass and elemental stock model "PhytoCalc" under clear cut conditions. Allg Forst Jagdztg 180: 15-21

Larcher W (2001) Ökophysiologie der Pflanzen. 6. Auflg, Ulmer, Stuttgart

Loveless AR (1961) A nutritional interpretation of sclerophylly based on differences in the chemical composition of sclerophyllous and mesophytic leaves. Ann Bot 25: 168184

Marks PL, Bormann FH (1972) Revegetation following forest cutting: mechanisms to return to steady state nutrient cycling. Science 176: 914-915

Mellert K-H, Kölling C, Rehfuess KE (1998) Vegetationsentwicklung und Nitrataustrag auf 13 Sturmkahlflächen in Bayern. Forstarchiv 69: 3-11 
Meziane D, Shipley B (1999) Interacting determinants of specific leaf area in 22 herbaceous species: effects of irradiance and nutrient availability. Plant Cell Environ 22: 447-459

Mölder A, Bernhardt-Römermann M, Schmidt W (2008) Herb-layer diversity in deciduous forests: Raised by tree richness or beaten by beech? Forest Ecol Manage 256: $272-281$

Morton AJ (1977) Mineral nutrient pathways in a Molinietum in autumn and winter. J Ecol 65: 993-999

Mrotzek R (1998) Wuchsdynamik und Mineralstoffhaushalt der Krautschicht in einem Buchenwald auf Basalt. Ber Forschungszentr Waldökosyst, Reihe A, Bd. 152, 197pp

Muukkonen P, Mäkipää R, Laiho R, Minkkinen K, Vasander H, Finér L (2006) Relationship between biomass and percentage cover in understorey vegetation of boreal coniferous forests. Silva Fenn 40: 231-245

Muller RN (2003) Nutrient relations of the herbaceous layer in deciduous forest ecosystems In: Gilliam FS, Roberts MR (ed) The herbaceous layer in forests of eastern North America. Oxford University Press, New York, pp 15-37

Myerscough PJ (1980) Epilobium angustifolium L. J Ecol 68: 1047-1074

Outcalt KW, White EH (1981) Understory biomass and nutrients 2 years after timber harvest in northern Minnesota. Can J For Res 11: 305-308

Palviainen M, Finér L, Mannerkoski H, Piirainen S, Starr M (2005) Responses of ground vegetation species to clear-cutting in a boreal forest: aboveground biomass and nutrient contents during the first 7 years. Ecol Res 20: 652-660

R Development Core Team (2008) R: A language and environment for statistical computing. R Foundation for Statistical Computing,Vienna, Austria. http://www.Rproject.org.

Ricard J-P, Messier C (1996) Abundance, growth and allometry of red rasperry (Rubus idaeus L.) along a natural light gradient in a northern hardwood forest. Forest Ecol Manage 81: 153-160

Rodenkirchen H (1995) Nutrient pools and fluxes of the ground vegetation in coniferous forests due to fertilizing, liming and amelioration. Plant Soil 168-169: 383-390

Röttgermann M, Steinlein T, Beyschlag W, Dietz H (2000) Linear relationships between aboveground biomass and plant cover in low open herbaceous vegetation. J Veg Sci 11: $145-148$ 
Scheffer F, Schachtschabel P (2002) Lehrbuch der Bodenkunde. 15. Auflg., Spektrum, Heidelberg

Schlichting E, Blume P, Stahr K (1995) Bodenkundliches Praktikum, 2. Auflg., Blackwell, Berlin

Schulze ED, Beck E, Müller-Hohenstein K (2002) Pflanzenökologie. Spektrum, Heidelberg

Schulze I-M, Bolte A, Seidling W, Stetzka K-M, Wellbrock N (2000) Vegetationskundliche Aufnahmen im Level II-Programm: Methoden, Auswertungen, erste Ergebnisse. Forstarchiv 71: 76-83

Schulze I-M, Bolte A, Schmidt W, Eichhorn J (2009) Phytomass, litter and net primary production of herbaceous layer. In: Brumme R, Khanna P (eds) Functioning and management of European beech ecosystems. Ecol Stud 208, pp 155-181

Scurfield G (1954) Deschampsia flexuosa (L.) Trin. J Ecol 42: 225-233

Seidling W (2005) Ground floor vegetation assessment within the intensive (Level II) monitoring of forest ecosystems in Germany: chances and challenges. Eur J Forest Res 124: 301-312

Shipley B (2000) Plasticity in relative growth rate and its components following a change in irradiance. Plant Cell Environ 23: 1207-1216

Siccama TG, Bormann FH, Likens GE (1970) The Hubbard Brook Ecosystem Study: productivity, nutrients, and phytosociology of the herbaceous layer. Ecol Monogr 40: 389-402

Steiner A, Bolte A, Schneider BU, Hüttl RF (1998) Phytomasse- und Nährelementvorräte unterschiedlich stickstoffbeeinflußter Kiefernbestände (Pinus sylvestris L.) des nordostdeutschen Tieflandes. Verh Ges Ökol 28: 421-428

Stevens PA, Hornung M (1990) Effect of harvest intensity and ground flora establishment on inorganic N leaching from Sitka spruce plantation in north Wales, UK. Biogeochemistry 10: 53-65

Strengbom J, Näsholm T, Ericson L (2004) Light, not nitrogen, limits growth of the grass Deschampsia flexuosa in boreal forests. Can J Bot 82: 430-435

Thompson K, Parkinson JA, Band SR, Spencer RE (1997) A comparative study of leaf nutrient concentrations in a regional herbaceous flora. New Phytol 136: 679-689

Van Andel J (1975) A study on the population dynamics of the perennial plant species Chamaenerion angustifolium (L.) Scop. Oecologia 19: 329-337 
Van Andel, J, Jager JC (1981) Analysis of growth and nutrition of six plant species of woodland clearings. J Ecol 69: 871-882

Van Baalen J, Prins EGM (1983) Growth and reproduction of Digitalis purpurea in different stages of succession. Oecologia 58: 84-91

Westoby M, Falster DS, Moles AT, Vesk PA, Wright IJ (2002) Plant ecological strategies: some leading dimensions of variation between species. Annu Rev Ecol Syst 33: 125159

Wilson PJ, Thompson K, Hodgson JG (1999) Specific leaf area and leaf dry matter content as alternative predictors of plant strategies. New Phytol 143: 155-162

Yarie J (1980) The role of understory vegetation in the nutrient cycle of forested ecosystems in the mountain hemlock biogeoclimatic zone. Ecology 61: 1498-1514

Zerbe S (1993) Fichtenforste als Ersatzgesellschaften von Hainsimsen-Buchenwäldern. Ber Forschungszentr Waldökosyst Reihe A, Bd 100, 173pp 
Changes in aboveground biomass, in nitrogen accumulation and in resource use related plant traits after clear and selection cutting in Norway spruce stands

Steffi Heinrichs, Uwe Klinck \& Wolfgang Schmidt Manuscript
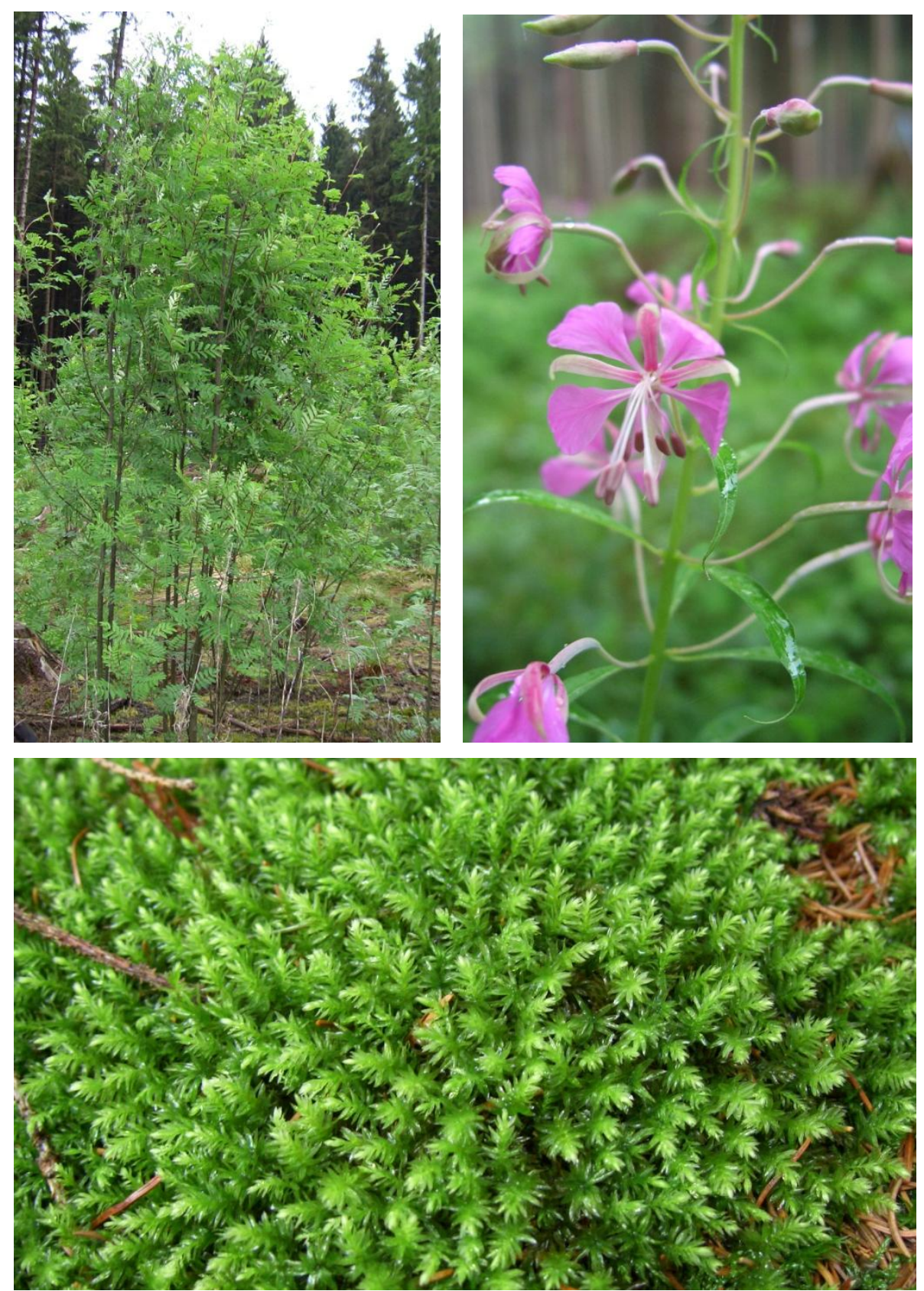
Top left: Sorbus aucuparia; Top right: Flowers of Epilobium angustifolium; Bottom: Mnium hornum. Photographs taken by Steffi Heinrichs. 


\begin{abstract}
This study investigated aboveground pools of biomass and nitrogen and the development of resource use related plant traits in the understorey vegetation of pure Norway spruce stands following selection cutting and small scale clear cutting at two sites in Germany. Biomass and nitrogen pools were estimated based on vegetation surveys using existing and determined allometric equations. Clear cutting induced a large increase in biomass and $\mathrm{N}$ pools. A more recent liming at one study site favoured especially species indicative of a fast nutrient acquisition (species with a high specific leaf area, an herbaceous growth form and indicators of nitrogen rich conditions). These functional groups seem to mitigate nitrogen losses after harvesting. Responses after selection cutting were similar, but not as pronounced. A lower light availability and persistent mosses deterred an expansion of nitrophilous species and tree regeneration, causing higher inorganic $\mathrm{N}$ concentrations in the soil solution measured under gaps compared to uncut stands. An earlier integration of tree regeneration into the stands could improve nitrogen uptake. Selection cutting plots showed no signs of soil impoverishment. On clear cuts though, an increasing biomass of tree regeneration caused depletion in the soil $\mathrm{N}$ pool. Logging residues could avert a productivity loss.
\end{abstract}

\title{
Introduction
}

Forests play an important role in soil and ground water protection due to their capacity to store nutrients and retain pollutants within the forest ecosystem. For example, Norway spruce plantations (Picea abies (L.) Karst.), widely distributed in Central Europe, accumulate large amounts of nitrogen within the humus layer (Meiwes et al. 2002). In many temperate forest areas though, the capacity of these spruce forests for retention is exceeded due to high nitrogen depositions, which causes nitrate leaching under closed forests (Mellert et al. 2005; Prietzel et al. 2006). After disturbance, the humus layer can function as an additional source for nitrogen and accelerate nitrogen losses from the ecosystem when mineralization is enhanced and erosion favoured. In light of this, the aspired large-scale conversion of Norway spruce forests into mixed stands in Europe, using mainly selection cutting and, in areas prone to windthrow, small scale clear cuttings, can lead to even higher losses and contamination of ground water (Bormann et al. 1974).

Besides microbial immobilization and soil adsorption (Vitousek and Matson 1984), the biomass and nitrogen accumulation of understorey vegetation can especially mitigate 
nitrogen losses after disturbance (Marks and Bormann 1972; Stevens and Hornung 1990; Mellert et al. 1998). The understorey vegetation is, in general, a very important component for nutrient cycling in forest ecosystems, although its part in biomass is often less than $2 \%$. Nutrients are recycled faster and nutrient concentrations are higher compared to the tree layer (Muller 2003; Moore et al. 2007). The amount of nitrogen, annually taken up and recycled, therefore depends on the characteristics of dominant species (Grime 1998), which reflect the environmental conditions. On moist soils with a high basic cation supply, fast growing herbaceous plants with a rapid nutrient turnover dominate; whereas on more nutrient poor soils woody species with a slower growth rate make up a large part of the understorey biomass (Graves et al. 2006). Thus, changes in plant traits that are related to growth rate and nutrient uptake after different cutting regimes, compared to spatial and temporal references, can indicate higher nitrogen availability and allow conclusions to be drawn about an excess or limitation of nitrogen and the risk of nutrient losses.

In temperate and boreal forests, many studies have been conducted on the response of the ground vegetation to clear cutting in terms of the aboveground biomass accumulation and nutrient content (e.g. Fahey et al. 1991; Palviainen et al. 2005). Only some studies have also considered the importance of understorey production after partial cutting (e.g. Bartsch 2000; Brais et al. 2004). A long-term before-after/controlimpact experiment, established in 2002 in north-western Germany, gave the opportunity to analyse and compare two cutting regimes, selection and clear cutting, intended to be used for spruce forest conversion, at two sites, differing slightly in stand age and stand history. In this study, the first five years after cutting were considered. Biomass and nitrogen accumulation were regarded, as well as community aggregated (i.e. weighted by the relative species abundance) plant traits related to growth rate and nitrogen acquisition (Ellenberg et al. 2001; Garnier et al. 2004; Kleyer et al. 2008). As many species in forests are growth limited by low light conditions we first hypothesised (1) an immediate increase in biomass and nitrogen content of the understorey after both cutting treatments in particular after clear cutting. (2) In addition, we expected higher nitrogen availability due to increased mineralization after both treatments, but especially after clear cutting, following the more drastic changes in microclimate. This will be expressed by the development of certain plant traits indicating a high growth rate (a shift towards herbaceous species, an increase in specific leaf area (SLA), a lower degree of woodiness, a lower proportion of evergreens, and an increase in nitrophilous 
species). (3) We also expected an influence of the different liming regimes at the study sites, with more distinct vegetation responses at the more recently limed site, where mineralization was enhanced before treatment creating a more favourable environment for microorganisms and where nitrophilous species were already established.

\section{Material and methods}

Site characteristics and vegetation survey

The present study is part of a long-term forest conversion experiment conducted in the Solling Hills, a low mountain range (up to $528 \mathrm{~m}$ a.s.l.) in the north-western part of Central Germany formed on Triassic sandstone covered with loess (see Heinrichs and Schmidt 2009). Two study sites were chosen, Neuhaus (500 m a.s.l., $1029 \mathrm{~mm}$ annual precipitation, $7.3{ }^{\circ} \mathrm{C}$ mean annual temperature) and Otterbach (300 m a.s.l., $912 \mathrm{~mm}$ annual precipitation, $7.8{ }^{\circ} \mathrm{C}$ mean annual temperature). At both sites brown soils are predominant with a low base saturation and good water supply. The humus form is humimor, which was ameliorated by liming before 1990 (Neuhaus and Otterbach) and in 2001 (only Neuhaus). Both study sites are dominated by Norway spruce forests; in the understorey either fern species or Oxalis acetosella are prevalent (Heinrichs and Schmidt 2009).

At each of the two study sites six experimental plots, 1 ha in size, were established, which were either treated with clear cutting, selection cutting or remained unmanaged in the autumn of 2003. The selection cutting followed a target diameter harvesting regime removing single trees with a $\mathrm{dbh} \geq 45 \mathrm{~cm}$ throughout the stand (for details see Heinrichs and Schmidt 2009). Logging residues were removed and accumulated on skidding tracks. Each 1 ha plot was subdivided into 20 permanent subplots of $400 \mathrm{~m}^{2}$. On most subplots the natural spruce regeneration was removed after the initial treatment, and either beech or Douglas fir saplings were planted. On four subplots natural spruce saplings were allowed to develop (spruce regeneration subplots). On 100 $\mathrm{m}^{2}$-plots in the center of these subplots vegetation relevés were conducted before (2002) and after cutting (once a year from 2004 until 2008; 2005 and 2008 data were obtained only on spruce regeneration subplots) in the unmanaged and treated stands (Heinrichs and Schmidt 2009). Additionally, on every subplot the mean shoot length was calculated by measuring the elongated shoot length of five individuals (when coverage was $<5 \%$ ) or ten individuals (when coverage was $\geq 5 \%$ ) for each species. 


\section{Soil sampling}

From each $100-\mathrm{m}^{2}$-spruce regeneration subplot nine soil samples were removed to a mineral soil depth of $20 \mathrm{~cm}$ in 2007. The cores were divided as follows: the organic layer (depth was recorded), 0-5 cm, 5-10 cm and 10-20 cm of mineral soil. The soil samples of each subplot were pooled and then sieved through a $2 \mathrm{~mm}$ mesh to remove stones and living plant materials. Fresh samples were used to determine $\mathrm{pH}_{\mathrm{KCL}}$ with a glass electrode. For the measurement of total $\mathrm{N}$ concentration the soil was dried at $65{ }^{\circ} \mathrm{C}$ for $48 \mathrm{~h}$ and finely ground. The concentration was determined by combustion (C/N analyzer, Carlo Erba Elemental Analyser).

\section{Biomass and nitrogen content estimation - understorey plants}

To estimate the aboveground biomass and nitrogen content of herbaceous species, small shrubs (Rubus fruticosus agg., R. idaeus), dwarf shrubs, akrokarp (cushion like) and pleurokarp (sward like) mosses the model PhytoCalc was used (Bolte 2006). Using percentage plant cover and mean shoot length measurements, this model calculates mean dry weights and nitrogen contents for each species on a subplot. The usage of PhytoCalc in forests has been validated for different regions in Germany, including the Solling (Mölder et al. 2008; Schulze et al. 2009). On clear cuts, however, the higher irradiance level leads to anatomical adaptations of plants making a correction necessary. Thus, the correction factors proposed by Heinrichs et al. (in press) for different growth groups (small herbs, tall herbs, grasses, sedges and rushes, dwarf-shrubs and small shrubs) were used on the data from clear cuts to get reliable dry weight estimations. These correction factors represent the difference in leaf dry matter content of the different growth groups under forest and clear cut conditions. An additional correction factor of 1.29 was calculated for ferns considering Athyrium filix-femina, Dryopteris dilatata and Pteridium aquilinum. The assignment of the herbs to the growth groups followed Bolte (2006). Epilobium and Hypericum (except H. humifusum) species, Persicaria maculosa and Teucrium scorodonia were allocated to the group of tall herbs.

\section{Biomass and nitrogen content estimation - tree regeneration}

Area related dry weight estimations on clear cuts for pioneer tree species (Betula species, Populus tremula, Salix caprea and Sorbus aucuparia) were conducted in two stages: (1) The aforementioned pioneer trees were destructively sampled in September 2007 considering different height classes $(0-20 \mathrm{~cm}, 20-50 \mathrm{~cm}, 50-100 \mathrm{~cm}, 100-300$ 
$\mathrm{cm},>300 \mathrm{~cm}-\mathrm{dbh}<7 \mathrm{~cm}$ ). In each height class at least seven trees of each species were sampled by measuring the root collar diameter and the maximum shoot length before cutting the trees close to the soil surface. The harvested tree components were dried at $65^{\circ} \mathrm{C}$ for at least $48 \mathrm{~h}$ and then weighed. Allometric functions for dry weight predictions were developed by using non-linear least-squares regression ( $D W=a R_{d} C^{b} S L_{\max }{ }^{c}$ ) relating the total dry weight of a tree (DW) to its root collar diameter $\left(R_{d}\right)$ and maximum shoot length (SLmax) with $a, b$, and $c$ as regression parameters. These regressions resulted in determination coefficients of $\mathrm{R}^{2}=0.99$ for all species (Table 1 ).

Table 1 Regression functions estimating aboveground dry weight (DW) in g per tree from root collar diameter $\left(R C_{d}\right)$ and shoot length measurements (SLmax) for different pioneer tree species following the regression equation DW = a $\mathrm{RC}_{\mathrm{d}} \mathrm{b} S \mathrm{~L}_{\max } \mathrm{c}$, and their adjusted coefficient of determination $\left(\mathrm{R}^{2}\right)$. Also given are coefficients of determination of the validation, contrasting observed dry weights of ten individuals per species and the according estimated dry weight. ${ }^{a}$

\begin{tabular}{lccccccc}
\hline & $\mathrm{n}$ & \multicolumn{3}{c}{ Regression parameters } & & $\mathrm{R}^{2}$ & \multicolumn{2}{c}{$\begin{array}{c}\mathrm{R}^{2} \\
\text { (Valid.) }\end{array}$} \\
\cline { 3 - 5 } & & $\mathrm{a}$ & $\mathrm{b}$ & $\mathrm{c}$ & & $0.96^{* * *}$ \\
Betula pendula & 28 & 0.549 & 1.896 & 0.801 & & $0.99^{* * *}$ & $0.93^{* * *}$ \\
Populus tremula & 26 & 0.038 & 1.270 & 1.388 & & $0.99^{* * *}$ & $0.97^{* * *}$ \\
Salix caprea & 26 & 0.191 & 1.632 & 1.035 & & $0.99^{* * *}$ & $0.89^{* * *}$ \\
Sorbus aucuparia & 25 & 0.128 & 1.683 & 1.135 & & $0.99^{* * *}$ & 0
\end{tabular}

Ten randomly chosen trees of each species were not included in the regression analysis, but were used for a validation by the contrasting observed and predicted dry weights. The validations as well showed significantly high $\mathrm{R}^{2}$-values ranging from 0.89 for $S$. aucuparia to 0.97 for $S$. caprea (Table 1). The allometric functions were applied to root collar diameters and corresponding heights measured for all tree individuals found on all $100 \mathrm{~m}^{2}$ subplots at the end of the growing period in 2007. Thus, area related dry weights were available for 2007. (2) To derive dry weight predictions for the other years, the area related dry weights determined for 2007 on each subplot were related to cover values (Cov) and medium shoot length values (SL) obtained in 2007 on all $100 \mathrm{~m}^{2}$ subplots using non-linear least-squares regression ( $D W=a \operatorname{Cov}^{b} S^{c}$ ). The regressions resulted in $\mathrm{R}^{2}$-values ranging from 0.53 to 0.77 (Table 2). Validations with ten randomly chosen subplots produced highl< significant $\mathrm{R}^{2}$-values above 0.75 (Table 2). 
Table 2 Regression functions estimating aboveground dry weight (DW) in $\mathrm{g} \mathrm{m}^{-2}$ from ground cover estimations (Cov) and shoot length measurements (SL) of different tree species following the regression equation DW $=a \operatorname{Cov}^{b} \mathrm{SL}^{c}$, and their adjusted coefficient of determination $\left(\mathrm{R}^{2}\right)$. Also given are coefficients of determination of the validation, contrasting estimated dry weights of the different species on ten subplots with regression functions according to Table 1 and dry weight estimations using ground coverage of the species on these subplots and the mean shoot length. ${ }^{\mathrm{a}}$

\begin{tabular}{|c|c|c|c|c|c|c|}
\hline & \multirow[t]{2}{*}{$\mathrm{n}$} & \multicolumn{3}{|c|}{ Regression parameters } & \multirow[t]{2}{*}{$\mathrm{R}^{2}$} & \multirow{2}{*}{$\begin{array}{c}\mathrm{R}^{2} \\
\text { (Valid.) }\end{array}$} \\
\hline & & $\mathrm{a}$ & $\mathrm{b}$ & $\mathrm{c}$ & & \\
\hline Betula pendula & 54 & $3.0910^{-6}$ & 0.638 & 3.103 & $0.75^{* * *}$ & $0.84^{* * *}$ \\
\hline Populus tremula & 56 & 0.053 & 0.577 & 1.123 & $0.57^{* * *}$ & $0.83^{* * *}$ \\
\hline Salix caprea & 52 & $5.8710^{-4}$ & 0.819 & 2.016 & $0.77^{* * *}$ & $0.75^{* * *}$ \\
\hline Sorbus aucuparia & 69 & 0.013 & 0.479 & 1.582 & $0.53^{* * *}$ & $0.77^{* * *}$ \\
\hline Picea abies (on clear cuts) & 20 & 1.359 & 1.068 & 0.610 & $0.97^{* * *}$ & n.d. \\
\hline
\end{tabular}

$\mathrm{a} * * *=\mathrm{p}<0.001 ;$ n.d. $=$ no data

The determined allometric functions from these relationships were applied to cover and mean shoot length values obtained on the clear cut subplots from 2004 until 2008.

Aboveground biomass of tree regeneration (Picea abies and pioneer tree species) on control and selection cutting plots was estimated using allometric functions presented by Bolte et al. (2009), which as well use the percentage cover of a tree species and its mean shoot length on a plot. This approach was also used for spruce regeneration on clear cuts, for which new allometric functions were determined (Table 2).

To determine nitrogen concentrations, the sampled trees were divided into stem, branch and leave compartment before being dried, milled and combusted using a $\mathrm{C} / \mathrm{N}$ analyzer (Carlo Erba Elemental Analyser). The highest concentrations were found in leaves followed by branches and stems (Table 3). By considering the weight distribution of the three different tree compartments, total concentrations were determined being highest for Betula pendula and lowest for Sorbus aucuparia (Table 3). Total nitrogen contents in the biomass $\left(\mathrm{g} \mathrm{m}^{-2}\right)$ for each year were calculated by multiplying the total concentration for a species by the mean dry mass of this species per plot estimated for each year.

As the natural dynamic after cutting was of interest, only the spruce regeneration subplots were regarded for data evaluation. On these plots other tree species showed a low cover and were thus disregarded. 
Table 3 Nitrogen concentrations of different tree components in \% dry weight and the total nitrogen concentration used for estimating the nitrogen content in the aboveground biomass of tree regeneration

\begin{tabular}{|c|c|c|c|c|c|c|c|c|}
\hline & $\mathrm{n}$ & Leaves & $\mathrm{n}$ & Branches & $\mathrm{n}$ & Stems & $\mathrm{n}$ & Total \\
\hline Betula pendula & 38 & $\begin{array}{c}2.38 \\
(0.06)\end{array}$ & 26 & $\begin{array}{c}1.00 \\
(0.05)\end{array}$ & 38 & $\begin{array}{c}0.84 \\
(0.04)\end{array}$ & 38 & $\begin{array}{c}1.38 \\
(0.06)\end{array}$ \\
\hline Populus tremula & 36 & $\begin{array}{c}2.30 \\
(0.06)\end{array}$ & 19 & $\begin{array}{c}1.01 \\
(0.04)\end{array}$ & 36 & $\begin{array}{c}0.71 \\
(0.03)\end{array}$ & 36 & $\begin{array}{c}1.25 \\
(0.04)\end{array}$ \\
\hline Salix caprea & 36 & $\begin{array}{c}2.00 \\
(0.06)\end{array}$ & 22 & $\begin{array}{c}1.01 \\
(0.04)\end{array}$ & 36 & $\begin{array}{c}0.73 \\
(0.03)\end{array}$ & 36 & $\begin{array}{c}1.17 \\
(0.03)\end{array}$ \\
\hline Sorbus aucuparia & 35 & $\begin{array}{c}1.62 \\
(0.07)\end{array}$ & 25 & $\begin{array}{c}1.12 \\
(0.05)\end{array}$ & 35 & $\begin{array}{c}0.81 \\
(0.05)\end{array}$ & 35 & $\begin{array}{c}1.00 \\
(0.04)\end{array}$ \\
\hline Picea abies (clear cut) & 56 & $\begin{array}{c}1.57 \\
(0.03)\end{array}$ & 28 & $\begin{array}{c}0.96 \\
(0.03)\end{array}$ & 36 & $\begin{array}{c}0.70 \\
(0.03)\end{array}$ & 56 & $\begin{array}{c}1.14 \\
(0.14)\end{array}$ \\
\hline Picea abies (forest) & 20 & $\begin{array}{c}1.80 \\
(0.05)\end{array}$ & & - & 20 & $\begin{array}{c}1.09^{a} \\
(0.03)\end{array}$ & 20 & $\begin{array}{c}1.37 \\
(0.04)\end{array}$ \\
\hline
\end{tabular}

a combined analyses of branches and stems

\section{Data evaluation}

Log transformed biomass values and nitrogen contents, as well as mean specific leaf area (SLA), the mean stem specific density (SSD; Kleyer et al. 2008) and the proportion of evergreen species (in combination with overwintering green species; Klotz et al. 2002) calculated per subplot were compared among the different treatments and among the studied years. The traits were weighted by biomass. The same comparison was also conducted for the proportion of different growth groups (mosses, herbs, graminoids, ferns, dwarf-shrubs, small shrubs, tree regeneration) and the proportion of different nitrogen indicator groups on the nitrogen content. Thereby Ellenberg indicator values for nitrogen (Ellenberg et al. 2001) were aggregated to indicator categories: indicators of nitrogen poor habitats (indicator values 1 to 3 ), indicators of moderately nitrogen rich habitats (indicator values 4 to 6), indicators of nitrogen rich habitats (indicator values 7 to 9) and no indicator. The comparison was made using a linear mixed model, which is appropriate as the study was conducted using a nested plot design with different observations conducted on the same plot. These observations were not independent, which can influence the variance of the data. Thus, the nesting has to be considered as a random effect. When comparing treatments, the variable treatment was analysed as a fixed effect for each year of observation. To compare the different years, year was used as a fixed effect, and also as a random effect to take into account the temporal pseudoreplication. For proportional data, a generalized linear mixed model was used with quasibinomial error distribution. 


\section{$N: P$ ratios}

The ratio of $\mathrm{N}$ to $\mathrm{P}$ can indicate a deficiency of nitrogen or phosphorus for a site. Thus, foliage of Deschampsia flexuosa, as a frequent grass species, and of P. abies, the dominant tree species over all treatments, was analysed for $\mathrm{N}$ by combustion and for $\mathrm{P}$ colorimetrically after pressure digestion using $65 \%$ nitric acid. For each species, leaves of 20 individuals on clear cuts and 20 under closed canopy (combining control and selection cutting plots) conditions were sampled, dried, milled and analysed. N:P ratios were calculated for each environmental condition and compared using a t-test for $D$. flexuosa and the Mann-Withney-test for P. abies due to a lack in normality distribution.

All analyses were conducted using R 2.8.1 (R Development Core Team 2008). The results were assumed to be significant at $\mathrm{p}<0.05$; $\mathrm{p}$-values $<0.1$ were considered as tendencies.

\section{Results}

\section{Soil parameters}

Soil analyses showed a significantly thinner organic layer on clear cuts compared to selection cutting (Neuhaus) or the control plots (Otterbach), respectively, as well as lower $\mathrm{C} / \mathrm{N}$ ratios in the organic layer compared to the control and in Otterbach also compared to the selection cutting plots (Table 4). Moreover, clear cuts showed in almost all layers, and in total, the lowest $\mathrm{N}$ pools and lowest $\mathrm{N}$ concentrations, whereas values detected on selection cutting plots were generally highest (Table 4). Differences were hardly significant; tendencies could be determined for total $\mathrm{N}$ pools between both cutting treatments for Neuhaus $(p=0.079)$ and Otterbach $(p=0.071)$.

\section{Changes in dry weight and nitrogen content}

A steady increase in dry weight and nitrogen content on clear cuts was detectable at both sites until 2008 (Table 5). Values were significantly higher from 2005 onwards (in Neuhaus from 2004 onwards, regarding dry weight) compared to the initial situation at both sites and compared to the control plots in Neuhaus. In Otterbach values on clear cuts were significantly different from values on control plots in 2007 and 2008, whereas tendencies for a significant difference existed already in 2005 (Dry weight: $\mathrm{p}=0.058, \mathrm{~N}$ : $\mathrm{p}=0.085$ ) and 2006 (Dry weight: $\mathrm{p}=0.051, \mathrm{~N}: \mathrm{p}=0.065$ ). Total values were lower in Neuhaus than in Otterbach, though the latter showed a large among plot variance. This is due to the remaining dominance of spruce regeneration on one clear cut plot in Otterbach causing high biomass and nitrogen content values. 
Table 4 Mean depth of the organic layer (OL), pH, N concentrations, N pools and the C/N-ratio of the OL and the mineral soil per $0-5,5-10$ and $10-20 \mathrm{~cm}$ soil depth and the total $\mathrm{N}$ pool of the analysed soil column for the control, selection cutting and clear cutting plots at both study sites. ${ }^{a}$

\begin{tabular}{|c|c|c|c|c|c|c|c|c|c|c|}
\hline \multirow{3}{*}{ Control } & \multicolumn{5}{|c|}{ Neuhaus } & \multicolumn{5}{|c|}{ Otterbach } \\
\hline & $\begin{array}{l}\text { depth } \\
{[\mathrm{cm}]} \\
\end{array}$ & $\begin{array}{l}\mathrm{N} \\
{[\mathrm{mg} / \mathrm{g}]}\end{array}$ & \multirow[t]{2}{*}{$\begin{array}{l}\mathrm{N} \\
{\left[\mathrm{g} / \mathrm{m}^{2}\right]}\end{array}$} & $\mathrm{C} / \mathrm{N}$ & pHкCL & \multirow[t]{2}{*}{$\begin{array}{l}\text { depth } \\
{[\mathrm{cm}]} \\
\end{array}$} & \multirow[t]{2}{*}{$\begin{array}{l}\mathrm{N} \\
{[\mathrm{mg} / \mathrm{g}]}\end{array}$} & \multirow[t]{2}{*}{$\begin{array}{l}\mathrm{N} \\
{\left[\mathrm{g} / \mathrm{m}^{2}\right]}\end{array}$} & \multirow[t]{2}{*}{$\mathrm{C} / \mathrm{N}$} & \multirow[t]{2}{*}{ pHкCL } \\
\hline & & & & & & & & & & \\
\hline OL & $\begin{array}{l}4.6 \mathrm{ab} \\
(0.3)\end{array}$ & $\begin{array}{l}14.3 \\
(0.3)\end{array}$ & $\begin{array}{l}131.7 \\
(3.9)\end{array}$ & $\begin{array}{l}24.3 \mathrm{a} \\
(1.5)\end{array}$ & $\begin{array}{l}3.9 \\
(0.3)\end{array}$ & $\begin{array}{l}5.7 \mathrm{a} \\
(0.1)\end{array}$ & $\begin{array}{l}13.0 \\
(0.3)\end{array}$ & $\begin{array}{l}137.2 \\
(1.35)\end{array}$ & $\begin{array}{l}25.5 \mathrm{a} \\
(0.1)\end{array}$ & $\begin{array}{l}3.3 \\
(0.0)\end{array}$ \\
\hline $0-5 \mathrm{~cm}$ & - & $\begin{array}{l}3.4 \\
(0.1)\end{array}$ & $\begin{array}{l}138.6 \\
(0.7)\end{array}$ & $\begin{array}{l}20.8 \\
(1.1)\end{array}$ & $\begin{array}{l}3.3 \\
(0.2)\end{array}$ & - & $\begin{array}{l}2.9 \\
(0.1)\end{array}$ & $\begin{array}{l}114.8 \\
(6.7)\end{array}$ & $\begin{array}{l}22.1 \\
(0.3)\end{array}$ & $\begin{array}{l}3.1 \\
(0.0)\end{array}$ \\
\hline $5-10 \mathrm{~cm}$ & - & $\begin{array}{l}1.9 \mathrm{a} \\
(0.0)\end{array}$ & $\begin{array}{l}94.4 \\
(3.3)\end{array}$ & $\begin{array}{l}17.6 \\
(0.4)\end{array}$ & $\begin{array}{l}3.2 \\
(0.1)\end{array}$ & - & $\begin{array}{l}1.3 \\
(0.0)\end{array}$ & $\begin{array}{l}65.7 \\
(1.2)\end{array}$ & $\begin{array}{l}19.2 \\
(0.2)\end{array}$ & $\begin{array}{l}3.3 \\
(0.1)\end{array}$ \\
\hline $10-20 \mathrm{~cm}$ & - & $\begin{array}{l}1.2 \\
(0.1)\end{array}$ & $\begin{array}{l}131.4 \\
(15.0)\end{array}$ & $\begin{array}{l}16.1 \\
(0.7)\end{array}$ & $\begin{array}{l}3.4 \\
(0.1)\end{array}$ & - & $\begin{array}{l}0.9 \\
(0.0)\end{array}$ & $\begin{array}{l}91.6 \\
(3.2)\end{array}$ & $\begin{array}{l}18.5 \\
(0.3)\end{array}$ & $\begin{array}{l}3.6 \mathrm{a} \\
(0.0)\end{array}$ \\
\hline$\Sigma \mathrm{OL}-20 \mathrm{~cm}$ & - & - & 496.1 & - & - & - & - & 409.3 & - & - \\
\hline \multicolumn{11}{|c|}{ Selection cutting } \\
\hline OL & $\begin{array}{l}5.8 \mathrm{a} \\
(0.1)\end{array}$ & $\begin{array}{l}14.6 \\
(1.2)\end{array}$ & $\begin{array}{l}161.3 \\
(0.5)\end{array}$ & $\begin{array}{l}23.0 \mathrm{ab} \\
(1.3)\end{array}$ & $\begin{array}{l}4.1 \\
(0.3)\end{array}$ & $\begin{array}{l}5.1 \mathrm{ab} \\
(0.0)\end{array}$ & $\begin{array}{l}13.8 \\
(1.0)\end{array}$ & $\begin{array}{l}133.1 \\
(4.7)\end{array}$ & $\begin{array}{l}25.3 \mathrm{a} \\
(0.4)\end{array}$ & $\begin{array}{l}3.5 \\
(0.2)\end{array}$ \\
\hline $0-5 \mathrm{~cm}$ & - & $\begin{array}{l}3.9 \\
(0.3)\end{array}$ & $\begin{array}{l}140.8 \\
(10.3)\end{array}$ & $\begin{array}{l}21.3 \\
(1.7)\end{array}$ & $\begin{array}{l}3.5 \\
(0.2)\end{array}$ & - & $\begin{array}{l}2.8 \\
(0.1)\end{array}$ & $\begin{array}{l}110.2 \\
(5.1)\end{array}$ & $\begin{array}{l}21.0 \\
(0.3)\end{array}$ & $\begin{array}{l}3.2 \\
(0.1)\end{array}$ \\
\hline $5-10 \mathrm{~cm}$ & - & $\begin{array}{l}2.3 \mathrm{~b} \\
(0.0)\end{array}$ & $\begin{array}{l}106.2 \\
(1.0)\end{array}$ & $\begin{array}{l}19.5 \\
(2.0)\end{array}$ & $\begin{array}{l}3.4 \\
(0.1)\end{array}$ & - & $\begin{array}{l}1.4 \\
(0.1)\end{array}$ & $\begin{array}{l}71.3 \\
(2.0)\end{array}$ & $\begin{array}{l}19.0 \\
(0.1)\end{array}$ & $\begin{array}{l}3.4 \\
(0.1)\end{array}$ \\
\hline $10-20 \mathrm{~cm}$ & - & $\begin{array}{l}1.4 \\
(0.1)\end{array}$ & $\begin{array}{l}125.6 \\
(16.5)\end{array}$ & $\begin{array}{l}20.2 \\
(1.9)\end{array}$ & $\begin{array}{l}3.6 \\
(0.1)\end{array}$ & - & $\begin{array}{l}1.0 \\
(0.0)\end{array}$ & $\begin{array}{l}108.8 \\
(1.3)\end{array}$ & $\begin{array}{l}18.0 \\
(0.5)\end{array}$ & $\begin{array}{l}3.8 \mathrm{ab} \\
(0.0)\end{array}$ \\
\hline$\Sigma \mathrm{OL}-20 \mathrm{~cm}$ & - & - & 533.9 & - & - & - & - & 423.4 & - & - \\
\hline \multicolumn{11}{|l|}{ Clear cutting } \\
\hline OL & $\begin{array}{l}3.8 \mathrm{~b} \\
(0.6)\end{array}$ & $\begin{array}{l}12.5 \\
(1.5)\end{array}$ & $\begin{array}{l}114.5 \\
(27.1)\end{array}$ & $\begin{array}{l}22.4 \mathrm{~b} \\
(1.2)\end{array}$ & $\begin{array}{l}4.4 \\
(0.3)\end{array}$ & $\begin{array}{l}3.9 \mathrm{~b} \\
(0.5)\end{array}$ & $\begin{array}{l}10.6 \\
(2.3)\end{array}$ & $\begin{array}{l}118.8 \\
(1.8)\end{array}$ & $\begin{array}{l}23.3 \mathrm{~b} \\
(0.1)\end{array}$ & $\begin{array}{l}3.5 \\
(0.0)\end{array}$ \\
\hline $0-5 \mathrm{~cm}$ & - & $\begin{array}{l}3.2 \\
(0.1)\end{array}$ & $\begin{array}{l}124.8 \\
(6.0)\end{array}$ & $\begin{array}{l}19.9 \\
(1.5)\end{array}$ & $\begin{array}{l}3.6 \\
(0.0)\end{array}$ & - & $\begin{array}{l}2.5 \\
(0.1)\end{array}$ & $\begin{array}{l}104.8 \\
(3.1)\end{array}$ & $\begin{array}{l}20.8 \\
(1.9)\end{array}$ & $\begin{array}{l}3.5 \\
(0.1)\end{array}$ \\
\hline $5-10 \mathrm{~cm}$ & - & $\begin{array}{l}1.9 \mathrm{a} \\
(0.0)\end{array}$ & $\begin{array}{l}93.0 \\
(1.2)\end{array}$ & $\begin{array}{l}18.4 \\
(1.8)\end{array}$ & $\begin{array}{l}3.4 \\
(0.2)\end{array}$ & - & $\begin{array}{l}1.2 \\
(0.0)\end{array}$ & $\begin{array}{l}66.1 \\
(2.5)\end{array}$ & $\begin{array}{l}19.6 \\
(1.5)\end{array}$ & $\begin{array}{l}3.6 \\
(0.1)\end{array}$ \\
\hline $10-20 \mathrm{~cm}$ & - & $\begin{array}{l}1.2 \\
(0.0)\end{array}$ & $\begin{array}{l}119.3 \\
(16.2)\end{array}$ & $\begin{array}{l}17.8 \\
(1.9)\end{array}$ & $\begin{array}{l}3.4 \\
(0.1)\end{array}$ & - & $\begin{array}{l}0.8 \\
(0.0)\end{array}$ & $\begin{array}{l}91.7 \\
(1.7)\end{array}$ & $\begin{array}{l}18.8 \\
(0.8)\end{array}$ & $\begin{array}{l}3.9 \mathrm{~b} \\
(0.0)\end{array}$ \\
\hline$\Sigma O \mathrm{~L}-20 \mathrm{~cm}$ & - & - & 451.1 & - & - & - & - & 381.4 & - & - \\
\hline
\end{tabular}

a Mean values are based on two replicates per treatment per site. Replicate values were obtained by averaging four subplots per replicate. SE is given in parentheses. Significant differences between treatments are indicated by different letters according to linear mixed model procedures $(p<0.05)$.

Compared to the initial situation in 2002, the immediate increase in dry weight and nitrogen pool in 2004 was higher after selection cutting than after clear cutting (Table 5). However, this increase levelled off after 2005, whilst clear cut values further increased. This resulted in significant differences between cutting treatments after 2006 and trends towards such difference already in 2005 (Dry weight: $\mathrm{p}=0.060, \mathrm{~N}: \mathrm{p}=0.067$ ) at least in Neuhaus. Dry weight and nitrogen contents on control plots also had the tendency to increase but to a lesser extent than after cutting treatments (Table 5). 


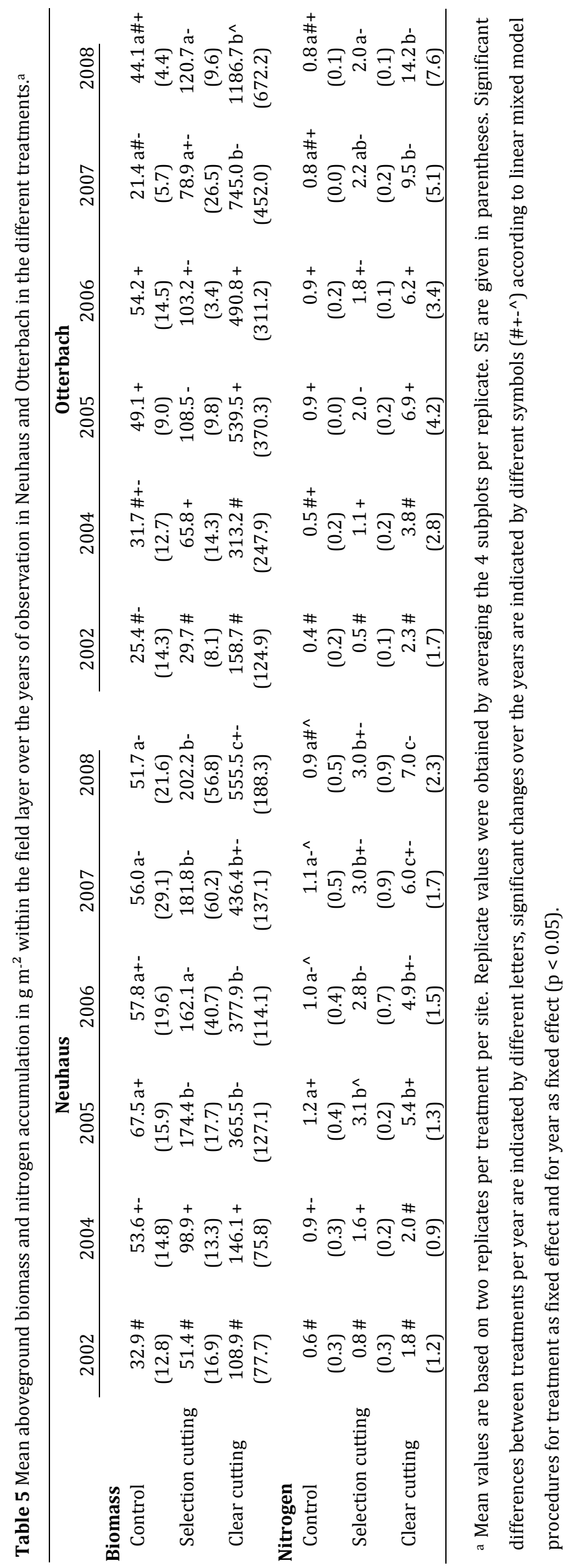


Vegetation responses based on plants traits

At Neuhaus, in the first growing season after clear cutting the mean SLA was significantly higher than in 2002, whilst SSD and the percentage of evergreens were lower. Otterbach showed a similar, but not significant pattern (Table 6). With ongoing succession this trend inverted leading to SLA and SSD values in 2008 that comply with values prior to treatment. Otterbach even showed a significantly lower mean SLA compared to 2002. The percentage of evergreens also increased, following the initial decrease, but at least in Neuhaus, had not yet reached pre-treatment levels in 2008. In Otterbach, the percentage of evergreens in 2008 was significantly higher on clear cuts than on the other treatments (Table 6).

The vegetation on selection cutting plots responded similarly to those on clear cuts, but at the end of the study period the SLA was higher, and the SSD and the percentage of evergreens were lower than on clear cuts, though differences were hardly significant (Table 6).

In addition, on the clear cuts at Neuhaus, immediately after treatment the vegetation was characterized by an increasing importance of graminoids, herbs, small shrubs, indicators of nitrogen rich, as well as nitrogen poor sites and a decrease in ferns and mosses, leading to significantly lower numbers of the two latter mentioned growth groups compared to controls and selection cutting plots (Fig. 1 and 2). Responses were smaller and slower in Otterbach. Here, the moss layer did not decrease until 2005 and the tree regeneration remained important. After 2005, the importance of herbs and, later also, of small shrubs decreased in favour of the tree regeneration at both sites.

In Neuhaus, vegetation on selection cutting plots responded similarly, with increases in herbs and graminoids, however, the importance of mosses and ferns remained stable. Also regarding nitrogen indicators, clear cut plots reacted faster than selection cutting plots. Significant differences between treatments were scarcely detectable, trends could be found for nitrogen rich indicators between clear cuts and control plots in 2004 ( $p=$ $0.076)$ and 2006 ( $p=0.080)$. Over the study period, small shrubs gained in importance especially in Otterbach, which is also represented by an increase in indicators of moderately nitrogen rich sites after both cutting treatments. Especially in 2007 and 2008, intermediate species contributed more to the $\mathrm{N}$ pool on selection cutting plots than on control $(2007: p=0.073 ; 2008: p=0.057)$ and clear cut plots $(2008: p=0.072)$. 


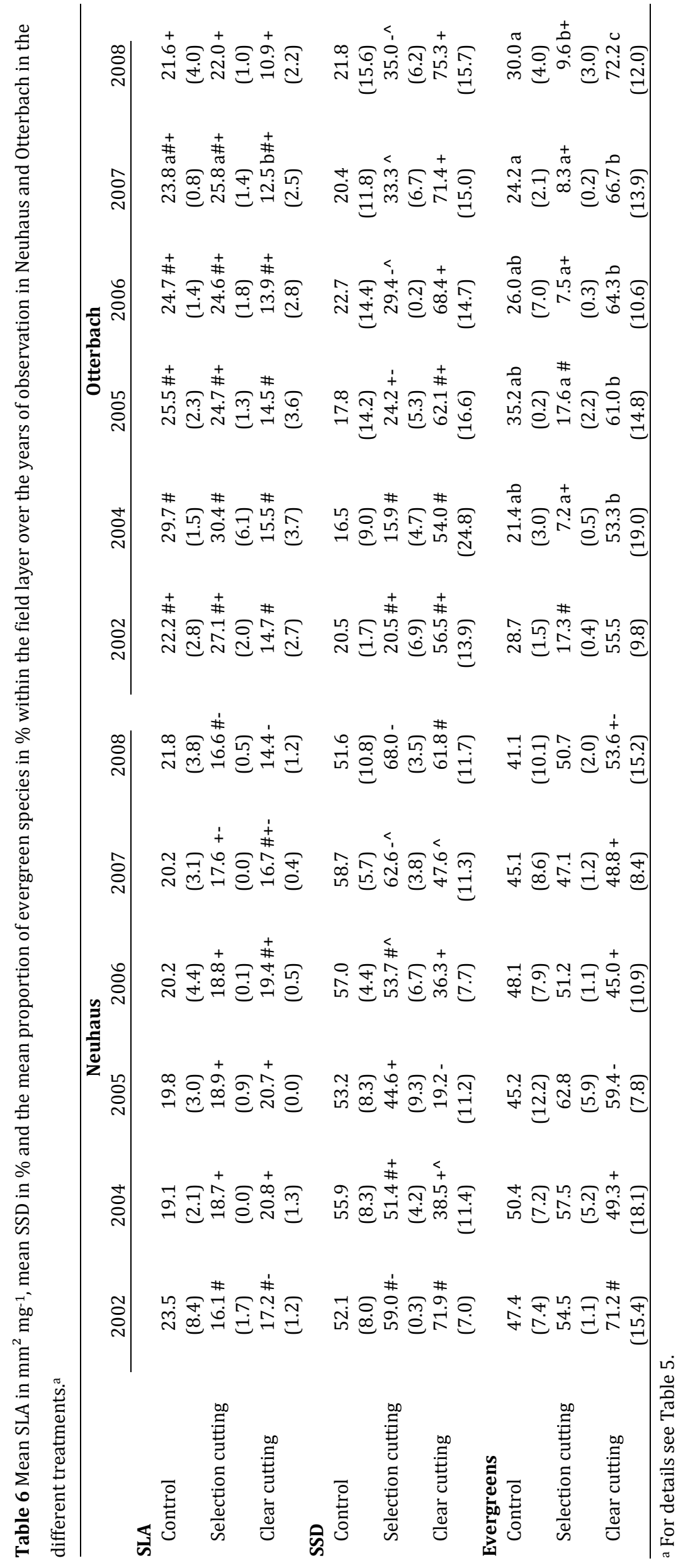


a)

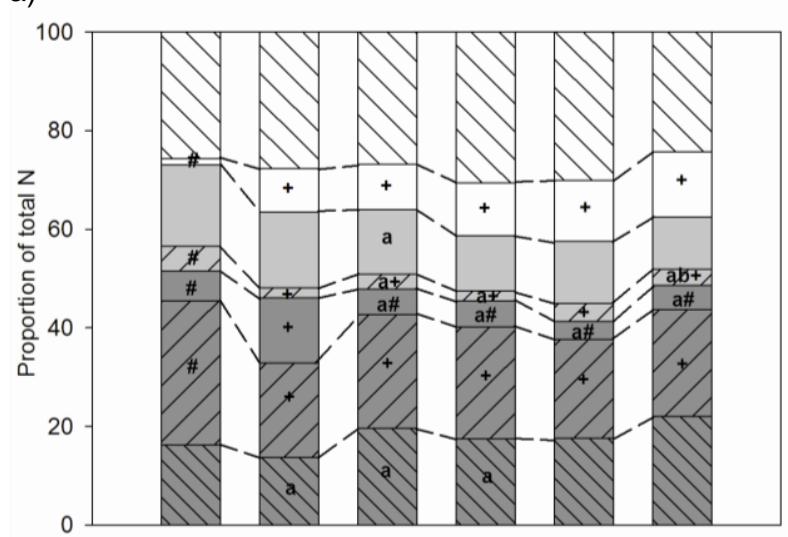

b)

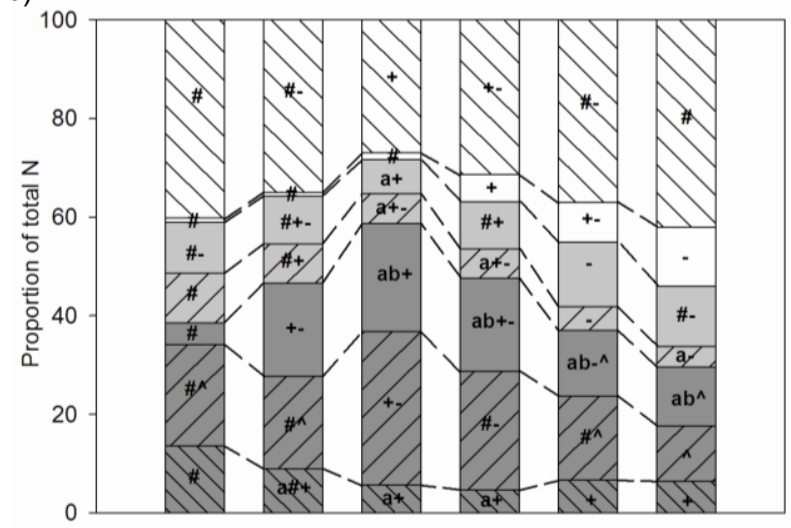

c)

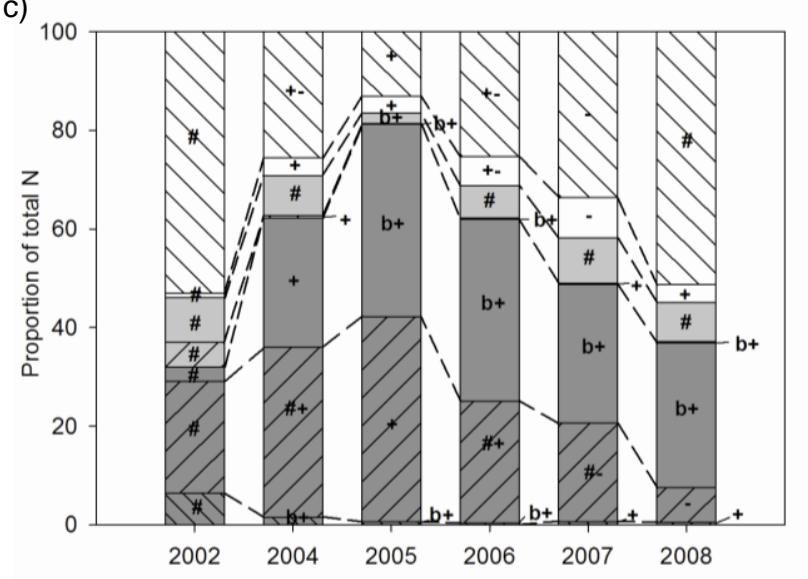

Otterbach
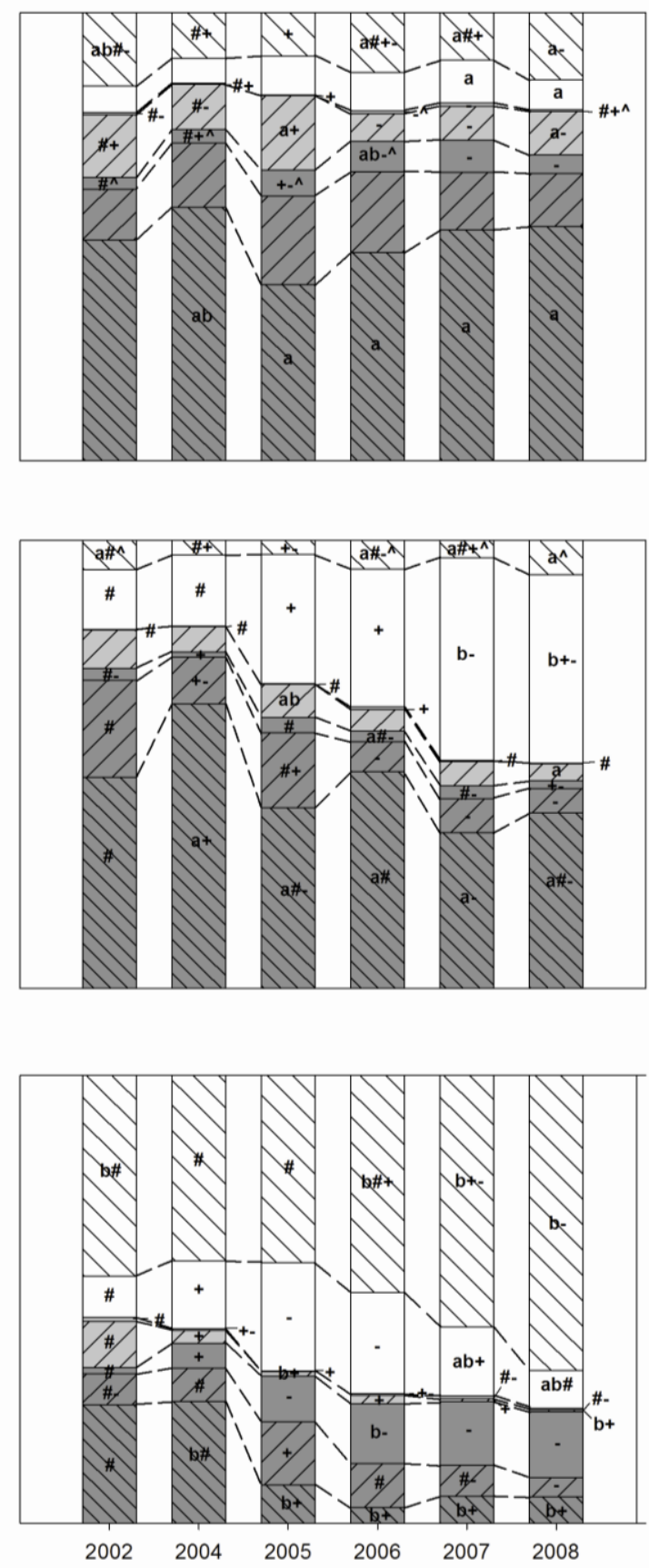

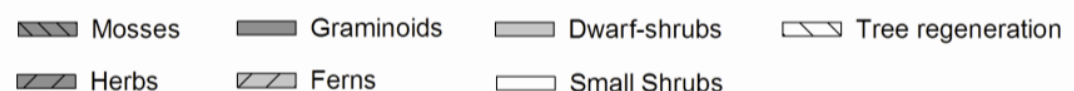

Fig. 1 Percentage contribution of different growth groups to the total nitrogen pool of the understorey vegetation in a) control plots, b) selection cutting plots, and c) clear cut plots at both study sites. Mean values are based on two replicated plots, each represented by four subplots. Different letters indicate significant differences between treatments within one year, different symbols $(\#,+,-, \wedge)$ show significant differences within one treatment according to generalized mixed model procedure. 
a)

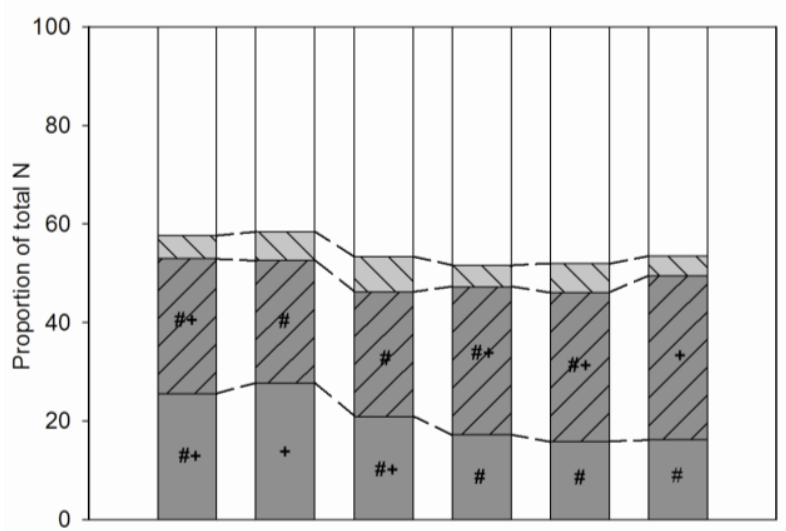

b)

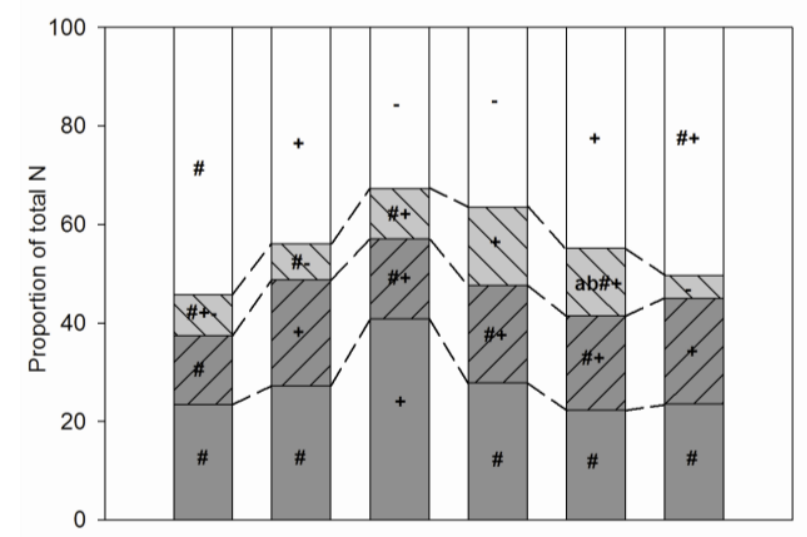

c)

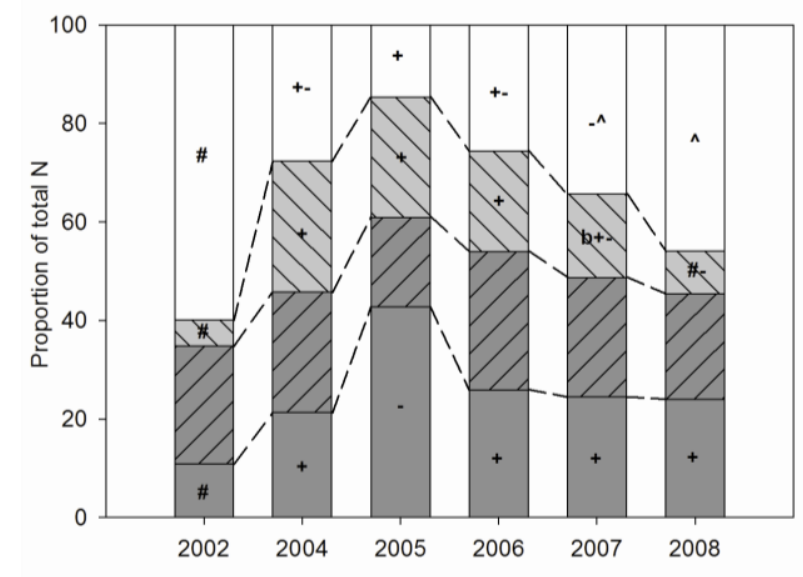

Indicators of:

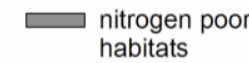

Neuhaus
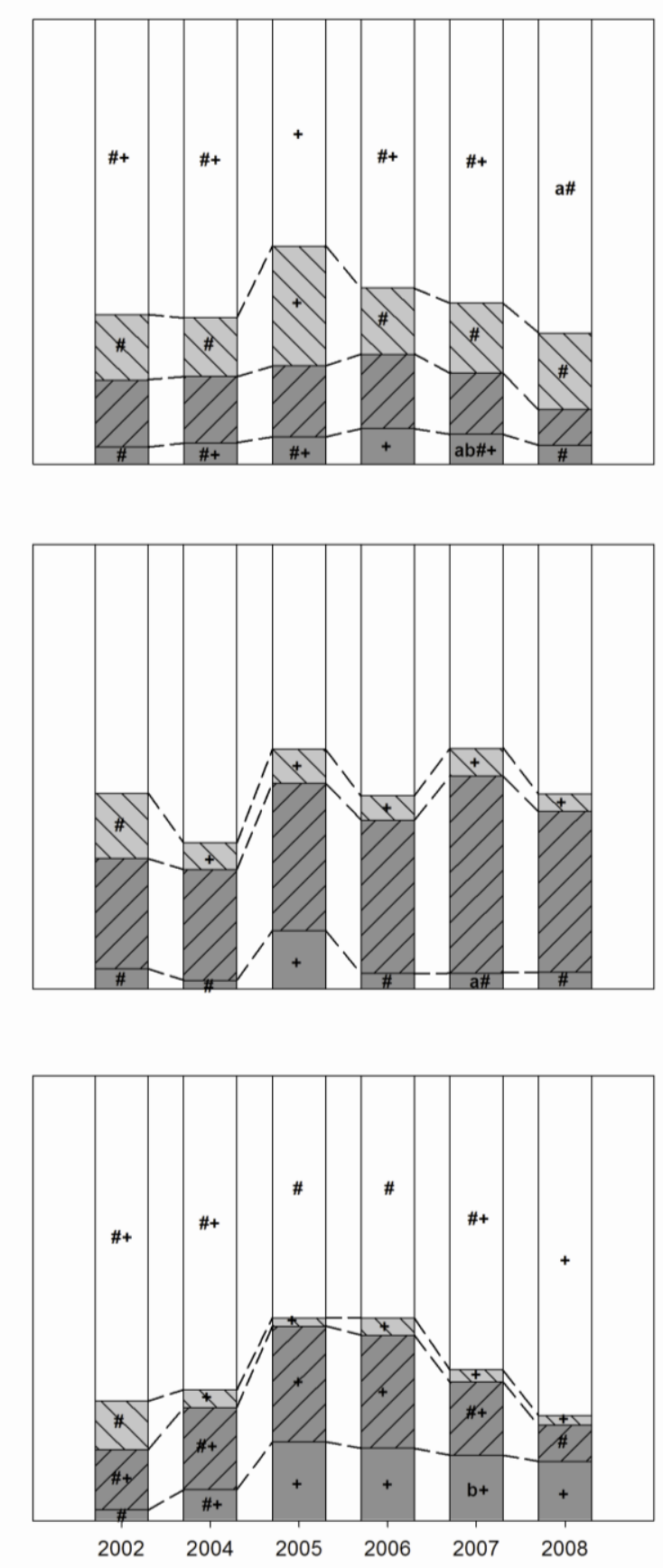

$\square \triangleright$ nitrogen rich habitats

Fig. 2 Percentage contribution of nitrogen indicator groups to the total nitrogen pool of the understorey vegetation in a) control plots, b) selection cutting plots, and c) clear cut plots at both study sites. For more details see Fig. 1.

Clear cutting also favoured low nitrogen indicators, whilst indicators of nitrogen rich soils declined following both treatments, leading to nearly significant differences between clear cuts and controls (2005: $p=0.057 ; 2007$ : $p=0.066 ; 2008$ : $p=0.061$; Fig. 
2) at the Otterbach site. In 2008 the proportion of nitrogen poor species was higher compared to 2002 on clear cuts at both study sites (Fig. 2)

The proportion of growth groups fluctuated on control plots during the study period, though small-shrubs increased in importance in Neuhaus over the years (Fig. 1). Concurrently, control plots showed the smallest changes regarding nitrogen indicator categories over the years (Fig. 2).

Both D. flexuosa and $P$. abies showed significantly lower $\mathrm{N}: \mathrm{P}$ ratios on clear cuts compared to forest conditions (Fig. 3).
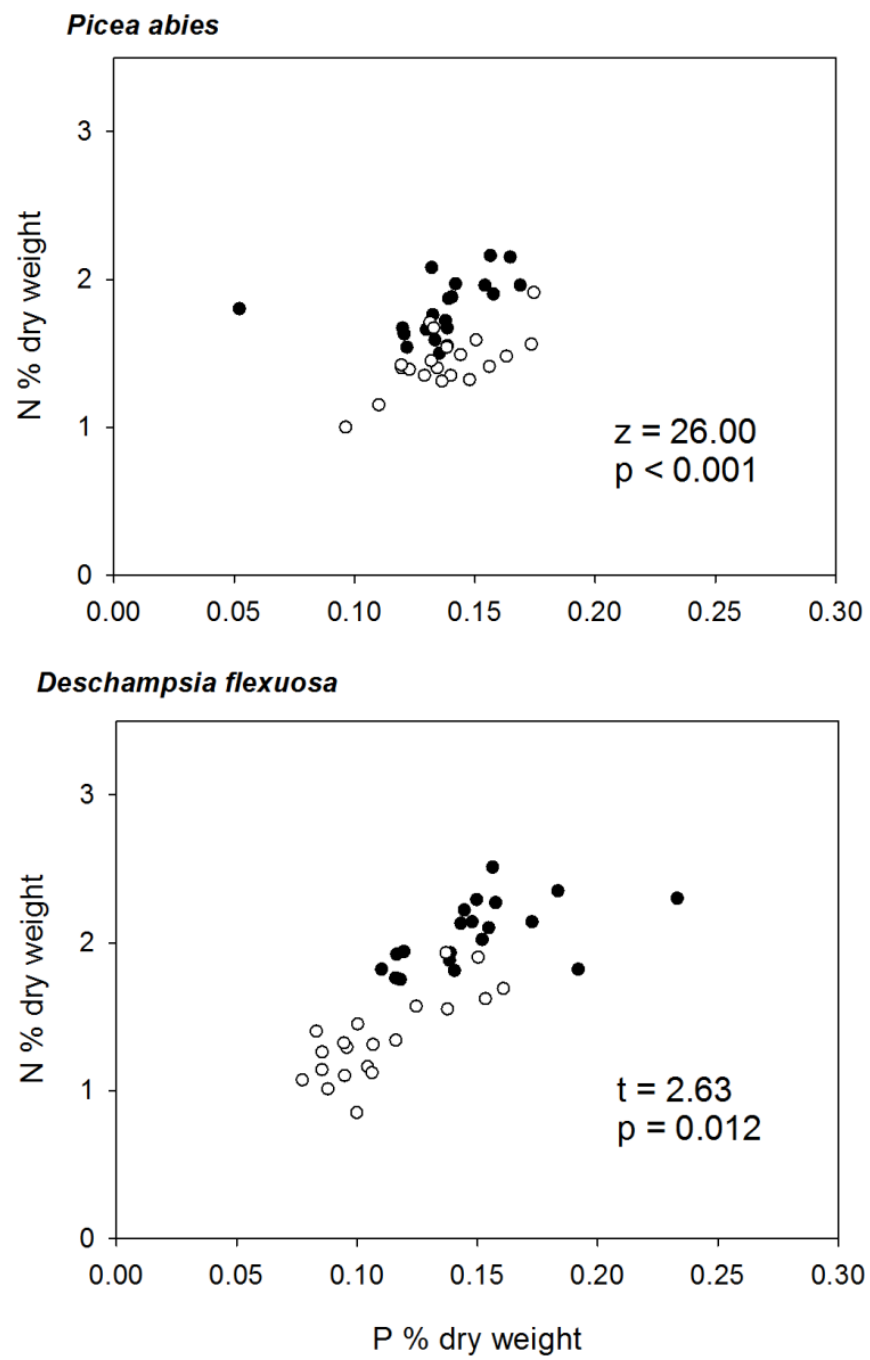

Fig. 3 Nitrogen concentration versus phosphorus concentration measured in 40 leaf samples of Picea abies and Deschampsia flexuosa, sampled under closed canopy $(\bullet)$ and on clear cuts $(\circ)$, and the results of the t-test and Mann-Whitney-Test, respectively, indicating the difference in the $\mathrm{N}: \mathrm{P}$ ratio within leaves between both environmental conditions.

\section{Linkage to nitrogen cycle}

The inorganic nitrogen concentration in soil leachate (at $1 \mathrm{~m}$ soil depth) was measured on one plot per treatment at each study site from the summer of 2004 until the end of 2007. When contrasting these concentrations with understorey nitrogen pools, it can be noted that the vegetation on clear cuts in Neuhaus was more effective in nitrogen 
retention than the vegetation in Otterbach (Fig. 4). Graminoids contributed most to the nitrogen pool in Neuhaus, whilst small shrubs did so in Otterbach. With the tree regeneration dominating in 2007, the Otterbach plot also showed lower nitrogen concentrations than measured under the control plot.

For both sites the highest inorganic nitrogen concentration was recorded under gaps in selection cutting plots despite an increase in the nitrogen pool of the understorey, which in Neuhaus was dominated by tree regeneration and in Otterbach by mosses and small shrubs (Fig. 4).

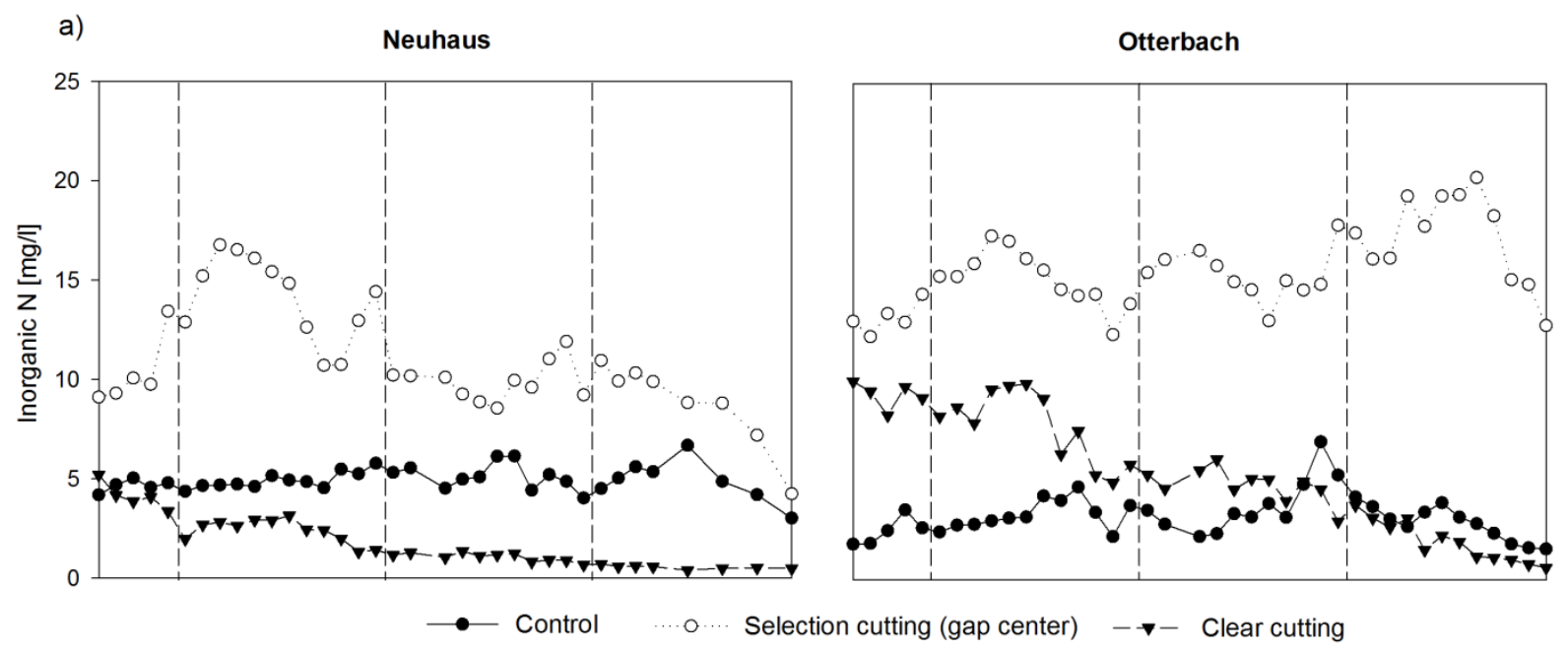

b)

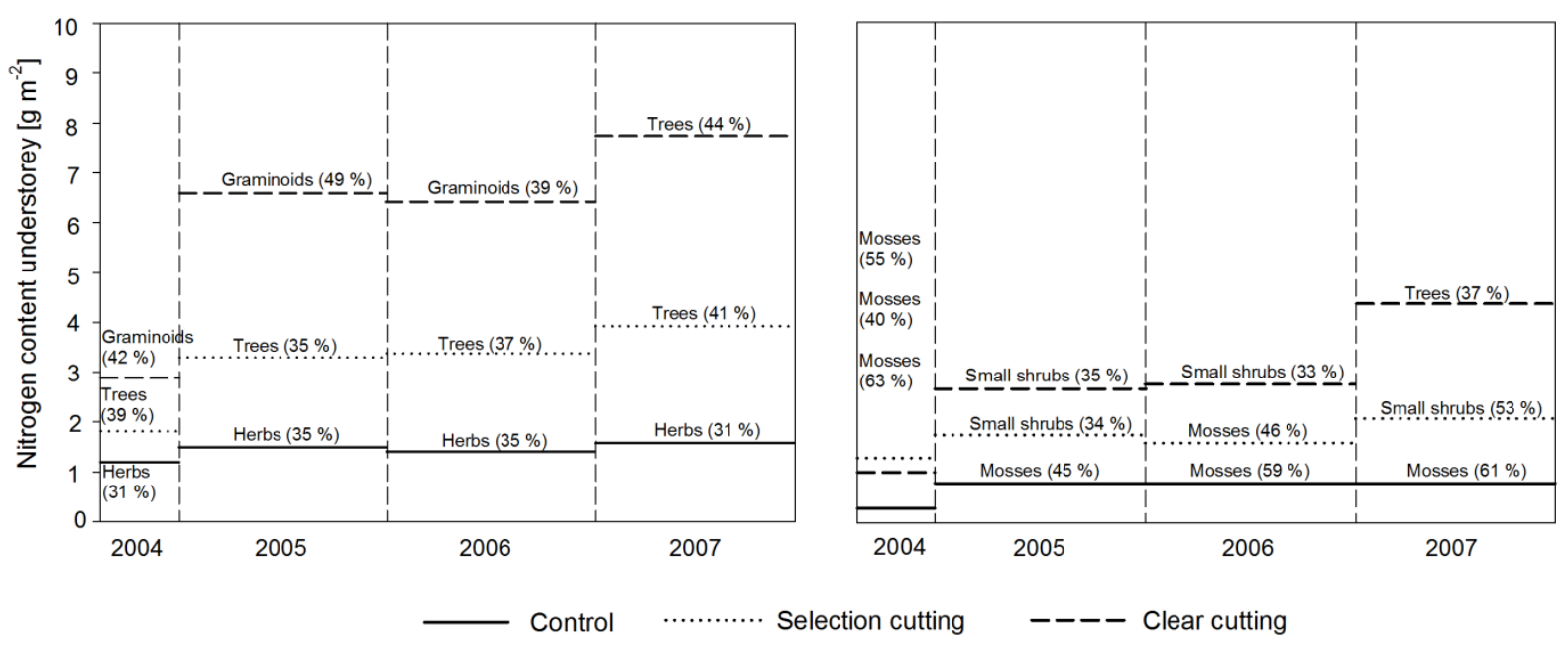

Fig. 4 a) Concentration of inorganic nitrogen in the seepage water at $1 \mathrm{~m}$ soil depth continuously measured from August 2004 to December 2007 on one plot per treatment (Data provided by U. Klinck), and b) the estimated nitrogen content of the understorey vegetation on the same plots in summers 2004 to 2007. Also given are the growth groups contributing most to the nitrogen content in the different years and treatments. 


\section{Discussion}

General development of the aboveground biomass and nitrogen contents

The estimated aboveground biomass and nitrogen pools in the uncut forests are within the ranges reported for spruce plantations of the Solling by Weckesser (2003). Although the studied stands grew under similar soil and climate conditions within one site, differences in biomass among plots assigned to different treatments existed prior to cutting, mainly due to differences in shrub layer-coverage $(P$. abies; Heinrichs and Schmidt 2009). Understorey composition can be very heterogeneous and reflect numerous microsites resulting from soil or canopy disturbances. Thus, it can be difficult to detect changes caused by a certain treatment (Jalonen et al. 1998). However, a clear increase in dry weight and nitrogen content after clear cutting could be detected. Estimated numbers were in the range found on clear cut plots in other temperate forest regions, where logging residues were removed (Fahey et al. 1991; Nilsson and Örlander 1999).

Due to soil disturbance and a slight increase in light availability, a biomass and nitrogen accumulation could also be detected on selection cutting plots following treatment. As found by Lee et al. (2002) two growing seasons after partial cutting, numbers were significantly higher than on uncut plots. However, higher rates of disturbance and severe changes in microclimate after clear cutting affected primarily the bryophyte layer and ferns negatively (Godefroid et al. 2005; Palviainen et al. 2005), but also woody species with exposed regeneration buds (Heinrichs and Schmidt 2009). At undisturbed microsites after selection cutting the cover of these sensitive taxa remained high. Thus, nutrient uptake and biomass development was highest on clear cut plots, where the more severe mechanical disturbance of the vegetation had to be compensated. Furthermore, especially in the first two years after clear cutting, underestimations in the $\mathrm{N}$ pool are possible as adaptations of the estimation model PhytoCalc on open site conditions were based on plant individuals sampled mainly four years after clear cutting, when the first mineralization impulse is over. Results given by Fahey et al. (1991) for A. capillaris and D. flexuosa two and four years after clear cutting suggest this to be the case.

On clear cut plots tree regeneration species, established after the initial disturbance, accounted for most of the biomass in 2007 and 2008. On selection cutting plots though, the undisturbed, dense bryophyte cover and a lower light availability suppressed the 
establishment of pioneer trees there, and consequently any further increase in biomass and nitrogen content.

\section{Changes in plant traits with implications for resource use}

The spruce plantations in the Solling are characterized by a large proportion of woody species and mosses, which account for most of the understorey biomass (Weckesser 2003). The high proportion of evergreens in the biomass in this study can be attributed to the appearance of Picea abies, which besides Sorbus aucuparia, Rubus idaeus and Vaccinium myrtillus, is generally one of the few woody species occurring in spruce forests. From the community aggregated plant traits a significant decrease in woodiness at both study sites in the first growing season after clear cutting can be noted, as well as a decrease in evergreens in Neuhaus. In combination with a significantly higher SLA, this suggests higher nitrogen availability after clear cutting and a faster resource acquisition by plants. SLA has been found to be positively correlated with relative growth rate, specific aboveground primary productivity, resource acquisition and nitrogen concentration within leaves; whilst woodiness and long leaf life span are associated with nutrient conservation and low nutrient losses at nutrient poor sites (Reich et al. 1992; Garnier et al. 2004). Higher nitrogen availability was induced by an increased nitrogen mineralization, leading to narrower $\mathrm{C} / \mathrm{N}$-ratios in 2004 compared to the same plots before clear cutting in the Oh horizon (Klinck et al. 2007). A significantly thinner organic layer on clear cuts compared to control plots suggests the forest floor as the nitrogen source, although clear cut plots showed slightly thinner organic layers already before treatment. Higher soil temperatures combined with a greater soil moisture content, in areas after harvesting compared to undisturbed forests, are generally thought to accelerate nitrogen mineralization and decomposition (Vitousek et al. 1979; Bormann and Likens 1994). A positive relationship between soil temperature and nitrogen mineralization in soils under spruce forests in the Solling Hills was determined by Bagherzadeh et al. (2008). Increased nitrogen availability and a rapid acquisition by the vegetation can also be deduced from the response of herbs and graminoids, and of species indicative of nitrogen rich habitats, particularly in Neuhaus. These contribute more to the $\mathrm{N}$ pool than before treatment. Species of the herbaceous field layer are commonly characterized by a higher nitrogen concentration due to a higher ratio of foliage to wood (Rodenkirchen 1995) and a higher nitrate reductase activity (Gebauer et al. 1998) compared to woody species. The vegetation at Otterbach did not show such a 
rapid response on clear cuts, with a higher proportion of herbs only in the second year after treatment and an increasing, but lower contribution, of graminoids to the nitrogen pool compared to Neuhaus. Here, nitrophilous Rubus-shrubs increased more (Rodenkirchen 1991); the tree regeneration (in particular P. abies), however, remained prevalent. A proportional increase in indicators of nitrogen poor conditions, does not contradict increased nitrogen availability. D. flexuosa (indicator value for nitrogen is 3), for example, increases most in growth by full light and high nitrogen concentrations in the soil (Strengbom et al. 2004).

However, there is a less pronounced response of resource use indicators in Otterbach. This originates in the lower liming frequency compared to Neuhaus. Liming promotes non-forest herb layer plants, and due to an increased nitrification, primarily nitrophilous species (Rodenkirchen 1991; Schmidt 2002), which are able to spread after disturbance, exploiting the increase in light and nutrient availability (Bartsch 2000). On the contrary, many bryophytes, characteristic of acidic spruce forests (Hypnum cupressiforme, Plagiothecium curvifolium, P. undulatum, Polytrichum formosum), decrease after liming or fertilization (Rodenkirchen 1991; Olsson and Kellner 2006). Consequently, the moss layer contributed much more to the understorey biomass and nitrogen content in Otterbach than in Neuhaus. Even in the first year after clear cutting, the importance of bryophytes had not decreased in Otterbach. This may have prevented the colonisation of wind-dispersed nitrophilous species that are able to take up excessive nitrogen rapidly. The ability of mosses to use soil nutrients is also limited; they mainly depend on atmospheric depositions (Turetsky 2003). This may explain higher inorganic nitrogen concentrations in the seepage water in comparison to controls on at least one clear cut plot in Otterbach. There mosses were still dominant regarding the contribution to the $\mathrm{N}$ pool in 2004, whereas in Neuhaus mainly graminoids expanded and made up most of the understorey's nitrogen content. Consequently, nitrogen concentrations measured in Neuhaus were at control levels (Fig. 4). At both study sites though, inorganic nitrogen levels decreased below control levels with an increasing nitrogen content of the understorey and with the expansion of pioneer trees. However, to quantify the total nitrogen output, the higher amount of seepage water on clear cuts has to be considered as well. First results from clear cuts in Otterbach show a steadily decreasing nitrate discharge despite high seepage water rates in years with extremely high precipitation (U. Klinck, personal communication, 2009). Here however, only inorganic nitrogen concentrations with soil leachate were regarded, which never exceeded $50 \mathrm{mg} \mathrm{l}^{-1}$ (the 
European drinking water standard) after clear cutting, indicating that nitrogen saturation has not yet been reached at these Solling sites compared for example to Bavarian sites (Kohlpaintner et al. 2009).

The highest nitrogen concentrations in soil leachate were detected under selection cutting gaps at both sites, despite an increase in understorey nitrogen pools and resource use indicators (Neuhaus: e.g. higher SLA, higher importance of herbs; Otterbach: less evergreens, more Rubus-shrubs) compared to 2002. A lower light availability compared to clear cutting conditions can be growth limiting even with a higher nutrient availability and thus prevent a faster expansion of nitrophilous species into the gaps (Elemans 2004). Moreover, mainly in Otterbach the moss layer was predominant, preventing the establishment or germination species (Fig. 4).

Nitrogen concentrations measured below gaps remained high compared to the other treatments as the vegetation could not increase the $\mathrm{N}$ pool further after 2005. Lasting losses of N under gaps were also found by Scharenbroch and Bockheim (2008) and by Prescott et al. (2003), though mostly under larger gaps. Stable values in the proportion of moderately nitrogen rich indicators and highest soil nitrogen pools in the soil column support a persistent high nitrogen availability. Contrary to this, on clear cuts, the plant uptake of nitrogen increased with the expansion of tree regeneration also from lower soil layers, which probably reduced the soil nitrogen content in comparison to control and selection cutting plots, although Klinck et al. (2007) determined a high heterogeneity in $\mathrm{N}$ Pools on plots both before and after clear cutting. Plant traits, however, support a reduction in available N, which had already started after 2005, when the SLA started to decrease reaching values below pre-treatment levels in 2008. An impoverishment of nutrients within the soil is additionally supported by a decreasing importance of species indicating nitrogen rich sites and herbs for the nitrogen pool, while the proportion of indicators of nitrogen poor soils remained stable. Moreover, N:P ratios of plant leaves on control (in combination with selection cutting) plots were significantly higher than on clear cut plots, indicating nitrogen limitation (Tessier and Raynal 2003). This is the result of a dilution effect caused by strong plant growth under limited nitrogen availability. As found in other studies these results indicate, that the risk of nitrate leaching lasts only for the first two to three years after clear cutting (Stevens and Hornung 1990; Weis et al. 2006); afterwards even a reduction in available nitrogen can occur. 


\section{Conclusions}

Our results underline the importance of understorey vegetation for an initial recovery of elemental uptake and cycling after clear cutting. Thereby, the understorey reacts with an increasing plant growth and a shift in species composition towards species characterized by a fast nutrient uptake. Liming increases the presence of such species, whose response after clear cutting can totally prevent higher nitrogen concentrations in the seepage water compared to uncut forests. Although the development of plant traits indicates higher nitrogen availability also following selection cutting, the increase in biomass was not sufficient to prevent higher soil leachate nitrogen concentrations compared to uncut plots, probably due to the still low light availability. Regarding the stands as a whole, the response under gaps may probably result in only slightly higher nitrogen discharge rates than found under controls. However, considering the forthcoming cutting procedures over the next 15 to 20 years until regeneration is established, the nitrogen output under this management regime will probably be similar in the end to that following clear cutting, especially when the response of regeneration remains slow. An earlier integration of tree regeneration into the stand (e.g. in natural gaps or in mature spruce stands with sufficient radiation for at least beech regeneration) might increase the ability for nutrient uptake after timber harvesting. In addition, larger gaps can probably promote the expansion of herbaceous, nitrophilous species within these gaps which can also contribute to reducing inorganic nitrogen leaching, though competition effects on regeneration will have to be monitored.

Compared to clear cutting, selection cutting plots do not show an impoverishment of the soil. This loss in productivity may negatively affect the growth of the aspired tree species that have to compete with grass and shrub species for nitrogen on clear cuts. Leaving logging residues on the plots that can function as a nutrient source might help to avoid this problem on the Solling sites.

\section{Acknowledgements}

The authors are grateful to Andrea Bauer, Karl-Heinz Heine, Andreas Parth, Heiko Rubbert and Theresa Waldmann for support during soil and tree sampling and to Ruth Gilbert for language correction. 


\section{References}

Bagherzadeh, A., Brumme, R. and Beese, F. 2008. Temperature dependence of nitrogen mineralization and microbial status in $\mathrm{O}_{\mathrm{H}}$ horizon of a temperate forest ecosystem. J. Forest Res. 19: 37-43.

Bartsch, N. 2000. Element release in beech (Fagus sylvatica L.) forest gaps. Water Air Soil Poll. 122: 3-16.

Bolte, A. 2006. Biomasse- und Elementvorräte der Bodenvegetation auf Flächen des forstlichen Umweltmonitorings in Rheinland-Pfalz (BZE, EU Level II). Ber. Forschungszentr. Waldökosyst. B72: 1-80.

Bolte, A., Czajkowski, T., Bielefeldt, J., Wolff, B. and Heinrichs, S. 2009. Schätzung der Biomassevorräte des Baum- und Strauchunterwuchses in Wäldern auf der Basis von Vegetationsaufnahmen. Forstarchiv 80: 222-228.

Bormann, F.H. and Likens, G.E. 1994. Pattern and Process in a forested ecosystem. Springer, New York.

Bormann, F.H., Likens, G.E., Siccama, T.G., Pierce, R.S. and Eaton, J.S. 1974. The export of nutrients and recovery of stable conditions following deforestation at Hubbard Brook. Ecol. Monogr. 44: 255-277.

Brais, S., Harvey, B.D., Bergeron, Y., Messier, C., Greene, D., Belleau, A. and Paré, D. 2004. Testing forest ecosystem management in boreal mixedwoods of northwestern Quebec: initial response of aspen stands to different levels of harvesting. Can. J. For. Res. 34: 431-446.

Elemans, M. 2004. Light, nutrient and the growth of herbaceous forest species. Acta Oecol. 26: 197-202.

Ellenberg, H., Weber, H.E., Düll, R., Wirth, V. and Werner, W. 2001. Zeigerwerte von Pflanzen in Mitteleuropa. Scr. Geobot. 18: 1-264.

Fahey TJ, Hill MO, Stevens PA, Hornung M and Rowland P 1991. Nutrient accumulation in vegetation following conventional and whole-tree harvest of Sitka spruce plantations in North Wales. Forestry 64: 271-288.

Garnier, E., Cortez, J., Billès, G., Navas, M.-L., Roumet, C., Debussche, M., Laurent, G., Blanchard, A., Aubry, D., Bellmann, A., Neill, C. and Toussaint, J.-P. 2004. Plant functional markers capture ecosystem properties during secondary succession. Ecology 85: 2630-2637. 
Gebauer, G., Hahn, G., Rodenkirchen, H. and Zuleger, M. 1998. Effects of acid irrigation and liming on nitrate reduction and nitrate content of Picea abies (L.) Karst. and Oxalis acetosella L. Plant Soil 199: 59-70.

Godefroid, S., Rucquoij, S. and Koedam, N. 2005. To what extent do forest herbs recover after clear cutting in beech forests? Forest Ecol. Manage. 210: 39-53.

Graves, J.H., Peet, R.K. and White, P.S. 2006. The influence of carbon-nutrient balance on herb and woody plant abundance in temperate forest understories. J. Veg. Sci. 17: 217-226.

Grime, J.P. 1998. Benefits of plant diversity to ecosystems: immediate, filter and founder effects. J. Ecol. 86: 902-910.

Heinrichs, S. and Schmidt, W. 2009. Short term effects of selection and clear cutting on the shrub and herb layer vegetation during the conversion of even-aged Norway spruce stands into mixed stands. Forest Ecol. Manage. 258: 667-678.

Jalonen, J., Vanha-Majamaa, I. and Tonteri, T. 1998. Optimal sample and plot size for inventory of field and ground layer vegetation in a mature Myrtillus-type boreal spruce forest. Ann. Bot. Fenn. 35: 191-196.

Kleyer, M., Bekker, R.M., Knevel, I.C., Bakker, J.P., Thompson, K., Sonnenschein, M., Poschlod, P., van Groenendael, J.M., Klimeš, L., Klimešová, J., Klotz, S., Rusch, G.M., Hermy, M., Adriaens, D., Boedeltje, G., Bossuyt, B., Dannemann, A., Endels, P., Götzenberger, L., Hodgson, J.G., Jackel, A.-K., Kühn, I., Kunzmann, D., Ozinga, W.A., Römermann, C., Stadler, M., Schlegelmilch, J., Steendam, H.J., Tackenberg, O., Wilmann, B., Cornelissen, J.H.C., Eriksson, O., Garnier, E. and Peco, B. 2008. The LEDA traitbase: a database of life-history traits of the Northwest European flora. J. Ecol. 96: 1266-1274.

Klinck, U., Fröhlich, D. and Meiwes, K.J. 2007. Zur Problematik der Quantifizierung von Cund N-Gehalten, C/N-Verhältnissen und C- und N-Vorräten der Humusauflage und des mineralischen Oberbodens. Allg. Forst Jagdztg. 179: 1-7.

Klotz, S., Kühn, I. and Durka, W. 2002. BiolFlor - Eine Datenbank mit biologisch ökologischen Merkmalen zur Flora von Deutschland. Schr.reihe Veg.kd. 38: 1-334.

Kohlpaintner, M., Huber, C., Weis, W., Göttlein, A. 2009. Spatial and temporal variability on nitrate concentration in seepage water under a mature Norway spruce (Picea abies (L.) Karst.) stand before and after clear cut. Plant Soil 314: 285-301.

Lee, J., Morrison, I.K., Leblanc, J.-D., Dumas, M.T. and Cameron, D.A. 2002. Carbon sequestration in trees and regrowth vegetation as affected by clear cut and partial 
cut harvesting in a second-growth boreal mixedwood. Forest Ecol. Manage. 169: 83101.

Marks, P.L. and Bormann, F.H. 1972. Revegetation following forest cutting: Mechanisms for return to steady state nutrient cycling. Science 176: 914-915.

Meiwes, K.J., Meesenburg, H., Bartens, H., Rademacher, P. and Khanna, P.K. 2002. Akkumulation von Auflagehumus im Solling - Mögliche Ursachen und Bedeutung für den Nährstoffkreislauf. Forst Holz 57: 428-433.

Mellert, K.H., Kölling, C. and Rehfuess, K.E. 1998. Vegetationsentwicklung und Nitrataustrag auf 13 Sturmkahlflächen in Bayern. Forstarchiv 69: 3-11.

Mellert, K.H., Gensior, A. and Kölling, C. 2005. Verbreitete Nitratbelastung des Waldsickerwassers. AFZ - Der Wald 4: 168-171.

Mölder, A., Bernhardt-Römermann, M. and Schmidt, W. 2008. Herb-layer diversity in deciduous forests: Raised by tree richness or beaten by beech? Forest Ecol. Manage. 256: $272-281$.

Moore, P.T., van Miegroet, H. and Nicholas, N.S. 2007. Relative role of understory and overstory in carbon and nitrogen cycling in a southern Appalachian spruce-fir forest. Can. J. For. Res. 37: 2689-2700.

Muller, R.N. 2003. Nutrient relations of the herbaceous layer in deciduous forest ecosystems. In The herbaceous layer in forests of eastern North America. Edited by F.S. Gilliam and M.R. Roberts. Oxford University Press, New York. pp. 15-37.

Nilsson, U. and Örlander, G. 1999. Vegetation management on grass dominated clear cuts planted with Norway spruce in southern Sweden. Can. J. For. Res. 29: 1015-1026.

Olsson, B.A. and Kellner, O. 2006. Long-term effects of nitrogen fertilization on ground vegetation in coniferous forests. Forest Ecol. Manage. 237: 458-470.

Palviainen, M., Finér, L., Mannerkoski, H., Piirainen, S. and Starr, M. 2005. Changes in the above- and below-ground biomass and nutrient pools of ground vegetation after clear-cutting of a mixed boreal forest. Plant Soil 275: 157-167.

Prescott, C.E., Hope, G.D., Blevins, L.L. 2003. Effect of gap size on litter decomposition and soil nitrate concentrations in a high elevation spruce-fir forest. Can. J. For. Res. 33: $2210-2220$.

Prietzel, J., Stetter, U., Klemmt, H.-J. and Rehfuess, K.E. 2006. Recent carbon and nitrogen accumulation and acidification in soils of two Scots pine ecosystems in Southern Germany. Plant Soil 289: 153-170. 
R Development Core Team 2008. R: A language and environment for statistical computing. R Foundation for Statistical Computing, Vienna, Austria. http://www.Rproject.org.

Reich, P.B., Walters, M.B. and Ellsworth, D.S. 1992. Leaf life-span in relation to leaf, plant, and stand characteristics among divers ecosystems. Ecol. Monogr. 62: 365-392.

Rodenkirchen, H. 1991. Entwicklung der Waldbodenvegetation auf den Versuchsflächen des Höglwald-Experiments im Beobachtungszeitraum 1983-1989. Forstwiss. Forsch. 39: 74-86.

Rodenkirchen, H. 1995. Nutrient pools and fluxes of the ground vegetation in coniferous forests due to fertilizing, liming and amelioration. Plant Soil 168-169: 383-390.

Scharenbroch, B.C., Bockheim, J.G. 2008. The effects of gap disturbance on nitrogen cycling and retention in late-successional hardwood-hemlock forests. Biogeochemistry 87: 231-245.

Schmidt, W. 2002. Einfluss der Bodenschutzkalkungen auf die Waldvegetation. Forstarchiv 73: 43-54.

Schulze, I.M., Bolte, A., Schmidt, W., Eichhorn, J. 2009. Phytomass, litter and net primary production of herbaceous layer. In Functioning and management of European beech ecosystems: Results from site specific long-term studies. Edited by R. Brumme and P.K. Khanna, Ecological Studies 208, pp. 155-181.

Stevens, P.A. and Hornung, M. 1990. Effect of harvest intensity and ground flora establishment on inorganic N-leaching from a Sitka spruce plantation in North Wales, UK. Biogeochem. 10, 53-66.

Strengbom, J., Näsholm, T. and Ericson, L., 2004. Light, not nitrogen, limits growth of the grass Deschampsia flexuosa in boreal forests. Can. J. Bot. 82: 430-435.

Tessier, J.T. and Raynal, D.J. 2003. Use of nitrogen to phosphorus ratios in plant tissue as an indicator of nutrient limitation and nitrogen saturation. J. Appl. Ecol. 40: 523-534.

Turetsky, M.R. 2003. The role of bryophytes in carbon and nitrogen cycling. The Bryologist 106(3): 395-409.

Vitousek, P.M. and Matson, P.A. 1984. Mechanisms of nitrogen retention in forest ecosystems: a field experiment. Science 225: 51-52.

Vitousek, P.M., Gosz, J.R., Grier, C.C., Melillo, J.M., Reiners, W.A. and Todd, R.L. 1979. Nitrate losses from disturbed ecosystems. Science 204: 469-474.

Weckesser, M. 2003. Die Bodenvegetation von Buchen-Fichten-Mischbeständen im Solling - Struktur, Diversität und Stoffhaushalt. Cuvillier, Göttingen. 
Weis, W., Rotter, V. and Göttlein, A. 2006. Water and element fluxes during the regeneration of Norway spruce with European beech: Effects of shelterwood-cut and clear-cut. Forest Ecol. Manage. 224: 304-317. 


\section{Chapter 5}

On the potential of the soil seed bank to facilitate or constrain

Norway spruce conversion

Steffi Heinrichs \& Wolfgang Schmidt

Manuscript
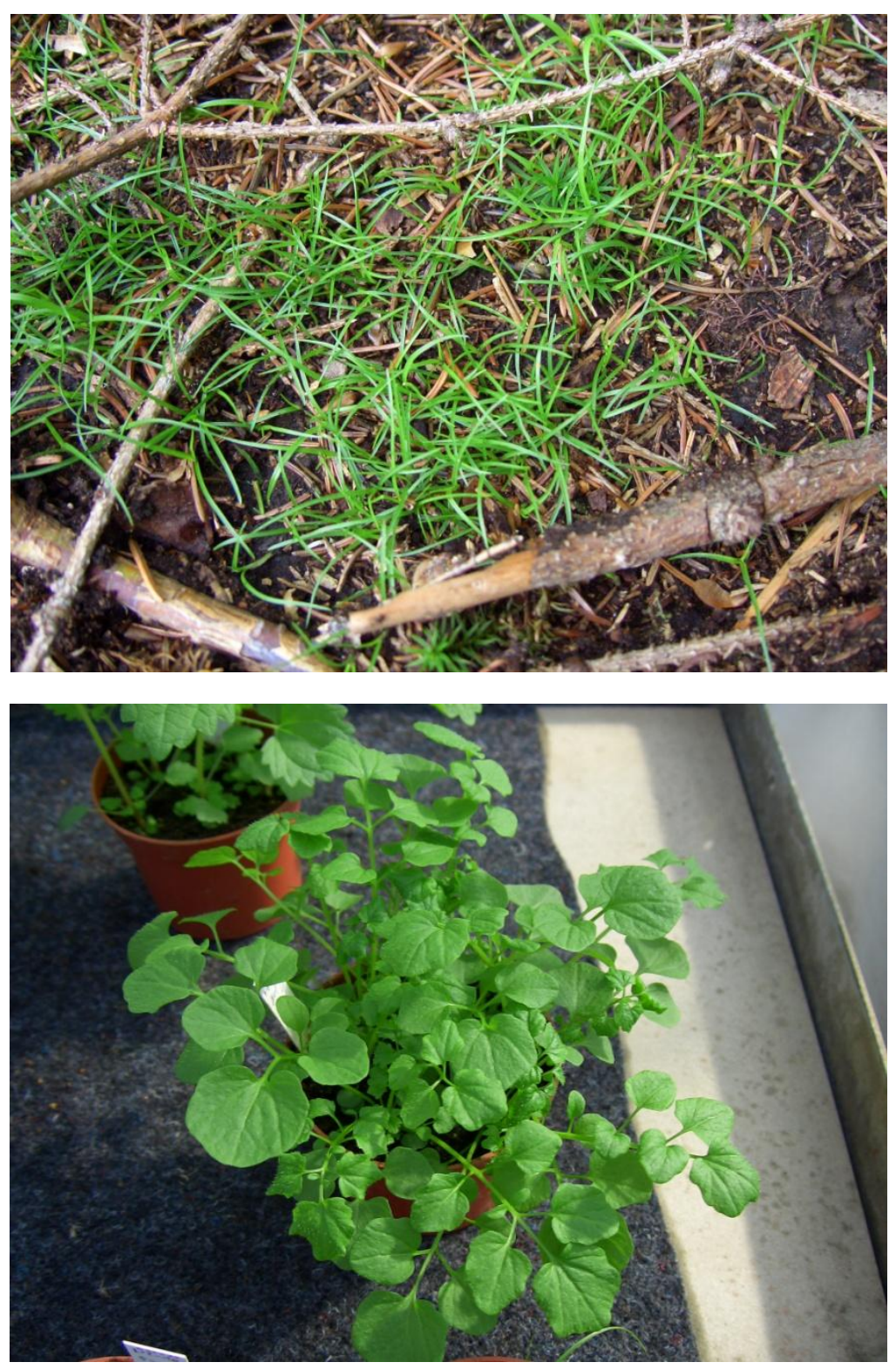
Top: Seedlings of Carex pilulifera on a disturbed subplot; Bottom: Pot with germinated seedlings of Cardamine flexuosa 


\begin{abstract}
Questions: How does the soil seed bank influence the understorey vegetation following selection cutting and clear cutting, and what are the management effects on size and composition of the seed bank? How abundant are competitive species in the seed bank? Can the seed bank be used to restore a late-successional forest community?

Location: About 100-year-old Norway spruce stands at two sites, differing in land use history, in the Solling Hills, Germany.

Methods: Aboveground vegetation and soil seed bank were compared between mature Norway spruce stands, adjacent four year old small scale clear cuts and stands managed by target diameter harvesting. We analysed species composition, species richness and seed density, and also the contribution of different functional groups to species diversity.
\end{abstract}

Results: Juncus effusus and Carex pilulifera were dominant in soils of mature forests and contributed to the post-harvest community. Competitive species showed low densities, but accumulated a persistent seed bank after both management practices. The different liming regimes at the two sites led to differences in accumulation success. Closed forest species were mainly absent from the seed bank, some ancient forest species though, are able to form persistent seed banks.

Conclusions: There is a low risk of competitive species, able to suppress the secondary succession process, to germinate from the soil seed bank after initial disturbance; the accumulation though, can cause problems with recurrent disturbance regimes. Characteristic species of naturally occurring acidic beech forests can be maintained within the seed bank and be part of the regenerating forest understorey community.

Keywords: Clear cutting, selection cutting, competition, community restoration, Juncus effusus

Nomenclature: Wisskirchen \& Haeupler (1998)

\title{
Introduction
}

Even-aged Norway spruce stands (Picea abies (L.) Karst.) are widespread over Central Europe, although, in most cases, not part of the potential natural vegetation. These stands were favoured because Norway spruce is easy to establish and has a high annual production (Spiecker 2003). Soon though, forest site degradations and the susceptibility to windthrow and bark-beetle attacks became obvious (Rothe et al. 2002). Thus, to maintain a multifunctional forest ecosystem in the future, a large-scale conversion of 
even-aged Norway spruce stands into more stable and site adapted mixed stands is intended in Germany and other European countries (Otto 1995; Wulf 2003). In general, this will be achieved by creating small gaps; at very susceptible sites though, small scale clear cuttings might be more suitable in order to avoid salvage cuttings (Spiecker 2003). Both forest management regimes will have a significant impact on the understorey plant community, an important forest component regarding biodiversity and nutrient cycling (Gilliam 2007). Depending on the disturbance intensity, changes in microclimate can cause an extirpation of many sensitive forest taxa (Hannerz \& Hånell 1997; Godefroid et al. 2005). Soil seed banks can reduce this risk (Stöcklin \& Fischer 1999) and be used for the restoration of plant communities (van der Valk \& Pederson 1989). Many authors though, have doubted the effectiveness of the seed bank for the regeneration of a latesuccessional forest vegetation after disturbance as typical forest species are often underrepresented in the seed bank. These species mainly rely on vegetative propagation and thus have a low annual production of short-lived seeds (Pickett \& McDonnell 1989; Decocq et al. 2004; Zobel et al. 2007). However, some shade-tolerant species have been detected in seed banks (e.g. Luzula pilosa: Granström 1982; Rydgren et al. 1998; Oxalis acetosella: Godefroid et al. 2006) indicating a lack of knowledge about the potential seed longevity of some forest species (Granström 1982).

Contrarily, other species can benefit from soil disturbance and a higher light and nutrient availability after timber harvesting (Huston 1994). Their post disturbance recovery often depends on the ability to survive disturbance by root fragments or rhizomes (Jonsson \& Esseen 1998) and to colonize plots from adjacent areas by vegetative spread or seed dispersal (van der Valk 1992). Especially following severe disturbance though, the soil seed bank is the major player in species establishment (Hill \& Stevens 1981; Bormann \& Likens 1994; Mayer et al. 2004). Thus, knowledge about the composition of soil seed banks under Norway spruce stands that are subject to conversion is important to be able to predict the future influence of the ground vegetation on stand development (Diaci 2002). Thereby, competitive species such as Rubus idaeus are especially crucial as they can constrain the growth of the forest regeneration (Romagosa \& Robison 2003). In the case of Rubus idaeus, this is not limited to clear cut conditions generally triggering a high germination rate and vegetative spread, but can also be the result after selection cutting as its germination is independent of light or temperature fluctuations (Lautenschlager et al. 1997; Mayer et al. 2004). In this context, also the accumulation of a persistent seed bank after forest 
management practices plays a significant role as this can facilitate a future site preemption and a repression of forest regeneration (Hyatt \& Casper 1999). Though Berger et al. (2004) discussed the weed risk within seed banks under Norway spruce stands in comparison to adjacent mixed stands in the context of conversion, there is no direct comparison between the management regimes clear cutting and selection cutting with an unmanaged control in terms of their seed bank and corresponding understorey vegetation (but see Buckley et al. 1997; Qi \& Scarratt 1998).

Thus, in the present study we analysed the role of the seed bank during the initial phase of Norway spruce conversion by comparing mature Norway spruce stands, adjacent four year old clear cuts and stands managed by selection cutting. Thereby Norway spruce forests at two locations were investigated, differing slightly in stand age and history. The following questions were addressed: (1) How does the seed bank influence the understorey vegetation after the different management regimes, and inversely has the management regime an effect on the size and composition of the transient and persistent seed bank in terms of individual species and functional species groups? (2) How severe is the risk of highly competitive species germinating from, and accumulating in, the seed bank after clear cutting and selection cutting? (3) How great is the potential of the seed bank for the restoration of a late-successional understorey community, characteristic for deciduous forests on acidic soils?

\section{Material and methods}

Study sites and experimental design

The present study is part of a forest conversion experiment and was conducted at two different sites in the Solling Hills, a low mountain range (up to $528 \mathrm{~m}$ above sea level) in the north-western part of Central Germany. The Solling is formed of Triassic sandstone covered with loess. Predominant are brown soils with a low base saturation and good water supply (see Heinrichs \& Schmidt 2009). The two study sites, Neuhaus

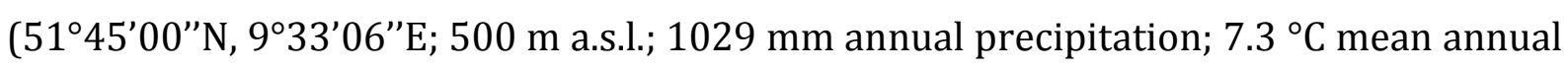

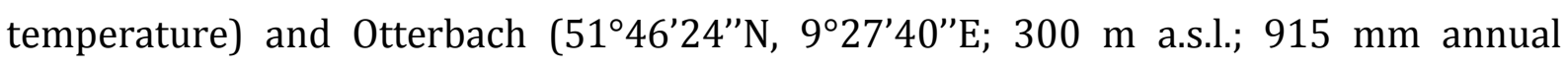
precipitation; $7.8{ }^{\circ} \mathrm{C}$ mean annual temperature), differ slightly in climate, stand age (Neuhaus: 109 years, Otterbach: 90 years old) and liming regime (Neuhaus: limed in 1990 and 2001; Otterbach: limed only in 1990). Both study sites are located on ancient forest sites with acidic species poor beech forests (Luzulo-Fagetum) as the potential natural vegetation. Since the Middle Ages though, deforestation and nutrient 
exploitation by litter raking and forest grazing have taken place converting especially the area around the study site Neuhaus into heathland (NMELF 1996). The study site Otterbach in the lower Solling was subject to a huge forestation with oak forests as this hardwood was mainly needed for construction. Since the end of the $19^{\text {th }}$ century though, the regionally absent Norway spruce was introduced in the Solling and widely planted. Today pure Norway spruce stands dominate both study sites and the herb layer is characterised by fern species, Oxalis acetosella and Vaccinium myrtillus.

At each study site six experimental plots, 1 ha in size, were established, which were either treated with clear cutting, selection cutting or remained unmanaged in the autumn of 2003. The selection cutting followed a target diameter harvesting regime removing single trees with a $\mathrm{dbh} \geq 45 \mathrm{~cm}$ throughout the stand (for details see Heinrichs \& Schmidt 2009). Each 1 ha plot was subdivided into 20 permanent subplots à $400 \mathrm{~m}^{2}$. On these subplots the natural spruce regeneration was removed after the initial treatment, and either beech or Douglas fir saplings were planted. On four subplots natural spruce saplings were allowed to develop (spruce regeneration subplots).

\section{Soil and vegetation sampling}

Vegetation relevés were conducted on $100 \mathrm{~m}^{2}$ in the centre of all subplots before cutting (year 2002) and after cutting (in the years 2004, 2006 and 2007) in the control and the impacted stands. The vegetation was sampled separately for the tree, shrub, herb and moss layer by compiling a species list and estimating the coverage of each appearing species. The coverage was estimated directly in percent (Heinrichs \& Schmidt 2009). In this study only the shrub and herb layer data were considered.

Soil cores were collected in the $100 \mathrm{~m}^{2}$-centre of the spruce regeneration subplots in early March 2007, after winter stratification and before new seed rain occurred. With an $8 \mathrm{~cm}$ diameter soil corer, nine soil samples per subplot were taken to a depth of $20 \mathrm{~cm}$ mineral soil. The soil cores were divided into the organic layer (the thickness was measured) and 0-5 cm, 5-10 cm and 10-20 cm mineral soil. Samples of each depth section were mixed per subplot.

\section{Seed bank analysis}

Soil samples per depth section, per subplot, were washed through a coarse $(2 \mathrm{~mm}$ mesh width) and a fine (0.2 $\mathrm{mm}$ mesh width) sieve, removing roots and vegetative parts, as well as coarse and fine soil material. Subsequently, the concentrated samples were 
spread out on plant trays with sterilized compost used as subsoil. The reduction of the soil material during seed concentration allowed the spreading of only a thin layer of soil to a thickness of ca. $0.5 \mathrm{~cm}$ on the trays in order to reduce the time needed for germination. Moreover, rubbing the seeds over the sieve during concentration should scarify the seed coat and stimulate germination (Bossuyt et al. 2000). The trays were put in an unheated glasshouse and were constantly watered from below. The trays were covered with gauze to prevent contamination from external seeds. Nevertheless, three plant trays with only the subsoil were placed in different areas of the glasshouse to control for any contamination. The trays were checked twice a week for emerging seedlings, which were then identified and removed. If identification was not possible, the seedlings were planted in separate pots and grown on until flowering. Most seeds germinated in the first three months; after 6 months the trays were allowed to dry out. The soil was mixed up and watered again. This procedure should give further stimulation for germination and bring probable buried seeds to the surface. After another 6 months the experiment was ended.

\section{Data evaluation}

To analyze if the contribution of species with long-lived seeds, probably originating from the soil seed bank, to the understorey vegetation changes after treatment, the mean seed longevity index (Kleyer et al. 2008) was calculated for each subplot before (2002) and after $(2004,2006,2007)$ treatment. This index ranges from 0 (strictly transient seeds) to 1 (strictly persistent seeds; Bekker et al. 1998).

To characterize the soil seed bank sampled in 2007 on spruce regeneration subplots, the seed density (viable seeds $\mathrm{m}^{-2}$ ) and the species richness (mean species number per subplot) were calculated for the total soil column and for each individual soil layer. The floristic overlap between seed bank and corresponding above-ground vegetation sampled in the same year on the same plots was assessed using Sørensen's Index (SI) based on presence-absence data. In addition, the seed density was calculated for each species and contrasted to the coverage of this species in the vegetation.

To assess the potential contribution of the seed bank to a typical forest plant community, the proportion of forest species following Schmidt et al. (2003) was assessed separately for the organic layer, reflecting the more transient seed bank, and the mineral soil, representing the persistent seed bank. The same was done for the accordant aboveground vegetation. In addition, the proportion of species with varying 
ecological strategies (competitors $=C$, ruderals $=R, C R$, stress tolerators $=S, C S$, and species with an intermediate strategy $=$ CSR, SR; Klotz et al. 2002) and of species belonging to different seed weight classes $(<0.2 \mathrm{mg}, 0.2-0.5 \mathrm{mg}, 0.5-1.0 \mathrm{mg}, 1.0-2.0$ mg, > 2 mg; Kleyer et al. 2008) were calculated for the soil layers and the aboveground vegetation present under each treatment. For mean longevity indices, species numbers and calculated Sørensen indices, the influence of treatment was analysed using an analysis of variance taking into account the spatial nesting as a random effect. This is important as several observations were conducted at the same plot. Consequently they are not independent, which can influence the variance of the data. If the variable treatment tended to have a significant influence $(\mathrm{p}<0.1)$, differences between individual treatments were analysed using linear mixed effect models, with treatment as fixed effect and the spatial nesting as random effect. Proportional data were compared using generalized linear mixed models with a quasibinomial error distribution.

All analyses were conducted with the R software (R 2.8.1; R Development Core Team, Vienna, Austria). Results were assumed to be significant at $\mathrm{p}<0.05$.

\section{Results}

Seed longevity index

Mean seed longevity showed no significant differences between plots before the treatments selection cutting and clear cutting were applied (Fig. 1).

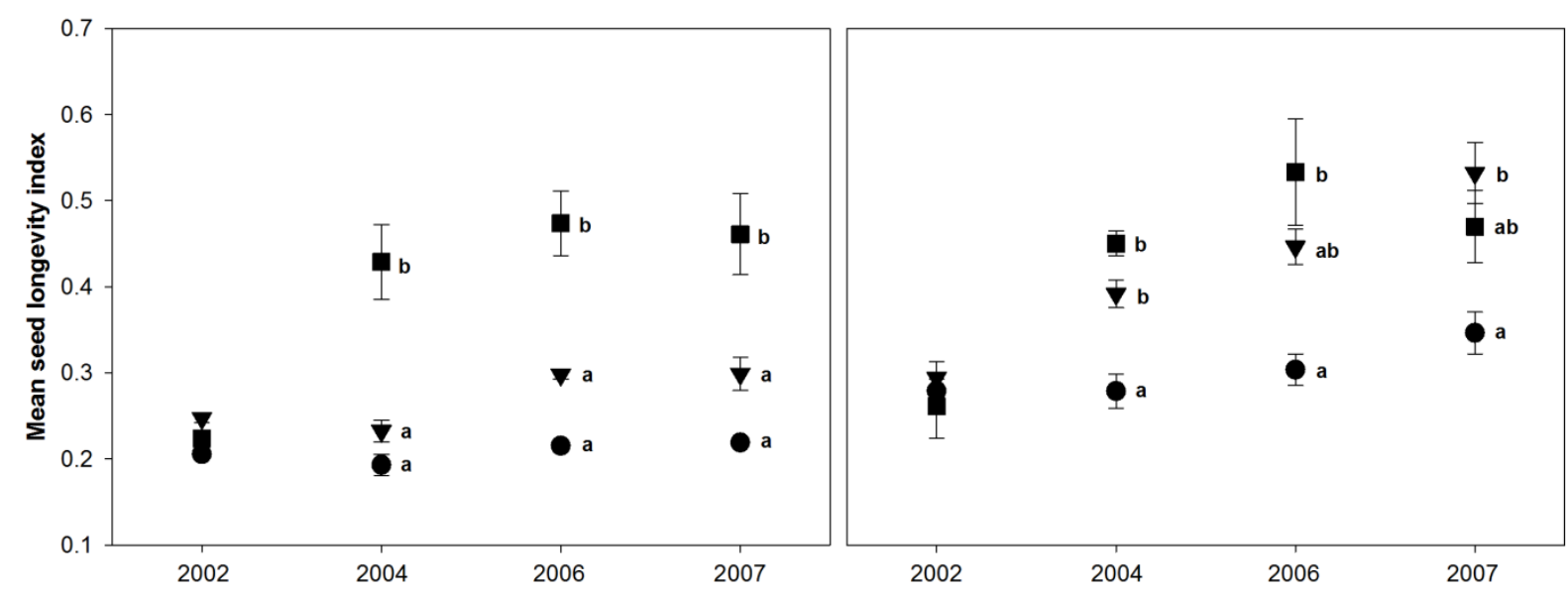

Fig. 1 Mean seed longevity index of the understorey vegetation detected before treatment in 2002 and after the treatments control $(\bullet)$, selection cutting $(\boldsymbol{\nabla})$ and clear cutting $(\boldsymbol{\bullet})$ in 2004, 2006 and 2007 in Neuhaus and Otterbach. Mean values are based on two replicate plots per treatment. Different letters indicate significant differences between treatments. 
Immediately afterwards though, clear cuts showed significantly higher index values than control plots at both sites. This was also the case for selection cutting plots in Otterbach. While the pattern remained stable in Neuhaus over the following years, at Otterbach the difference between clear cuts and the control plots decreased in 2007 (Fig. 1).

\section{Seed bank characteristics under different treatments}

Chenopodium album and Salix caprea germinated in the control trays. Thus, both species were not considered during data evaluation. Furthermore, due to the soil sample treatment, large seeded trees (Fagus sylvativa, Quercus spec., Prunus spec.) could not be regarded.

At both sites, clear cuts showed the highest mean seed density (Neuhaus: 54121 seeds $/ \mathrm{m}^{2}$; Otterbach: 32187 seeds $/ \mathrm{m}^{2}$ ) compared to the other treatments (control: 8181 seeds $/ \mathrm{m}^{2}$ in Neuhaus and 10835 seeds $/ \mathrm{m}^{2}$ in Otterbach; selection cutting: 11635 seeds $/ \mathrm{m}^{2}$ in Neuhaus and 8204 seeds $/ \mathrm{m}^{2}$ in Otterbach) with the highest numbers in the organic layer. On control plots the upper mineral soil had the highest densities (Fig. 2).
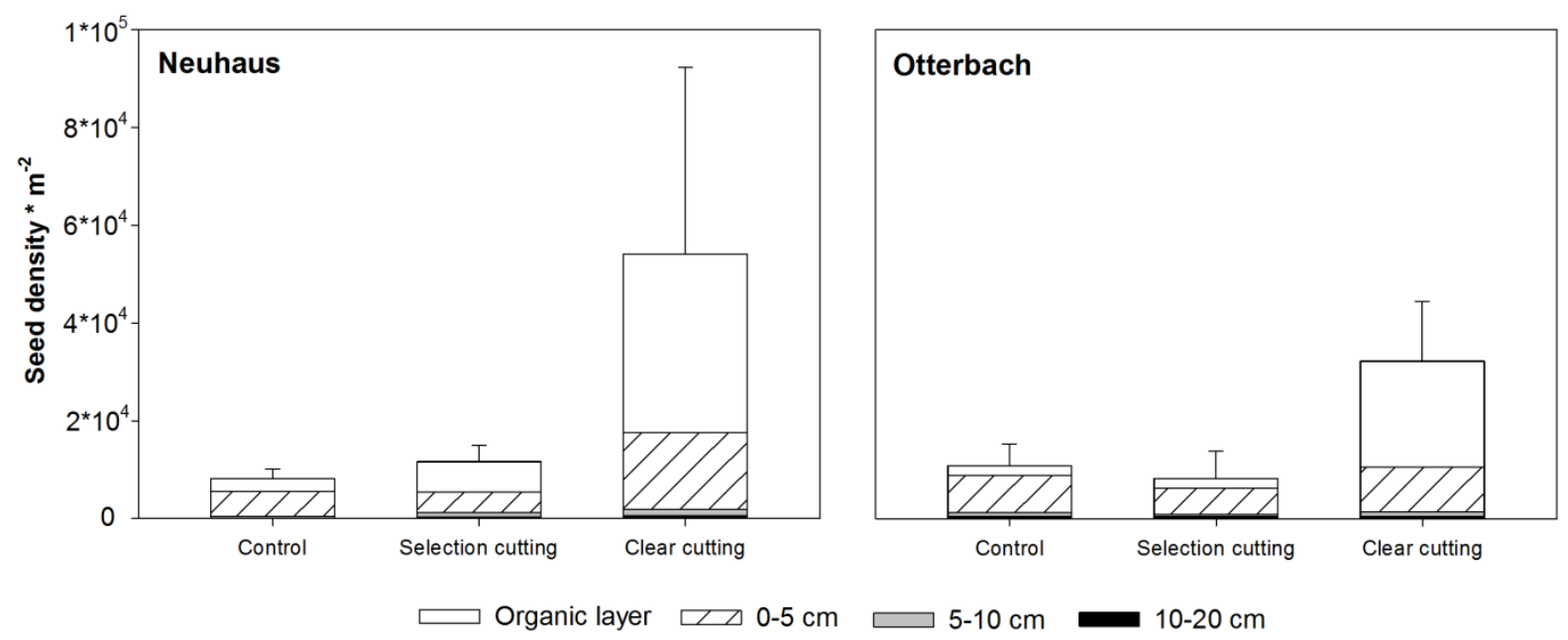

Fig. 2 Mean seed densities $( \pm$ SE) for the analysed soil layers under the different treatments at Neuhaus and Otterbach. No significant differences could be detected between treatments (Neuhaus: $F_{(2,3)}=1.333, p=0.385$; Otterbach: $\left.\mathrm{F}_{(2,3)}=2.653, \mathrm{p}=0.219\right)$.

Densities were, however, highly variable between subplots of the same plot (e.g. 5239 vs 12998 seeds $/ \mathrm{m}^{2}$ on a control plot in Neuhaus, 3957 vs. 106125 seeds/m² on a clear cut plot in Otterbach), thus, no significant differences could be detected between treatments. The most abundant species at both sites and over all treatments were Juncus effusus (in general making up around $50 \%$ of all seeds found) and Carex pilulifera, 
whereas Digitalis purpurea produced high seed densities on clear cuts and selection cutting plots. Agrostis capillaris, Epilobium ciliatum and Senecio sylvaticus were mainly abundant on clear cuts (Tables 1 and 2).

Table 1 Mean seed densities in seeds $\mathrm{m}^{-2}$ (D) and mean cover values in \% (C) and the coefficients of variation (CV) of species sampled on spruce regeneration subplots in Neuhaus in 2007 on unmanaged control plots, on plots managed with selection cutting or on clear cuts. Only species found with seed densities $\geq 5$ seed $\mathrm{m}^{-2}$ or cover values $\geq 0.1 \%$ are shown.

\begin{tabular}{|c|c|c|c|c|c|c|c|c|c|c|c|c|}
\hline \multirow{3}{*}{ In vegetation only } & \multicolumn{4}{|c|}{ Control } & \multicolumn{4}{|c|}{ Selection cutting } & \multicolumn{4}{|c|}{ Clear cutting } \\
\hline & $\mathrm{C}$ & $\mathrm{CV}$ & $\mathrm{D}$ & $\mathrm{CV}$ & $\mathrm{C}$ & $\mathrm{CV}$ & $\mathrm{D}$ & $\mathrm{CV}$ & $\mathrm{C}$ & $\mathrm{CV}$ & $\mathrm{D}$ & $\mathrm{CV}$ \\
\hline & & & & & & & & & & & & \\
\hline Picea abies & 3.3 & 0.3 & . & . & 9.7 & 0.3 & . & . & 5.2 & 1.1 & . & \\
\hline Holcus mollis a & & . & . & . & 0.7 & 0.3 & . & 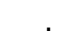 & 3.5 & 1.4 & r. & \\
\hline Sorbus aucuparia a & 0.1 & 0 & . & . & 0.5 & 1.1 & . & . & 1.6 & 0.3 & 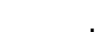 & \\
\hline Stellaria graminea & . & . & . & . & . & . & . & . & 0.2 & 1.2 & . & \\
\hline Trientalis europaea ${ }^{\mathrm{b}}$ & + & 0 & . & . & + & 0.2 & . & 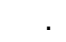 & 0.2 & 0.7 & . & \\
\hline Molinia caerulaea & + & 0.7 & . & . & + & 0.3 & . & . & 0.1 & 1.4 & 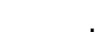 & \\
\hline Geranium robertianum a & . & . & . & . & 0.3 & 1.3 & . & . & . & - & - & \\
\hline Phalaris arundinacaea & . & . & . & . & 0.4 & 1.4 & . & . & . & . & . & \\
\hline Sambucus nigra a & + & 1.4 & 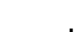 & . & 0.1 & 1.4 & . & & . & 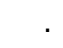 & . & \\
\hline In vegetation and seed $b$ & & & & & & & & & & & & \\
\hline Juncus effusus & + & 1.4 & 5283 & 0.6 & + & 0.5 & 6159 & 0.9 & 3.9 & 1.1 & 39186 & 1.3 \\
\hline Carex pilulifera ${ }^{\mathrm{a}}$ & + & 0 & 989 & 0.2 & 0.1 & 0 & 575 & 0.4 & 4.4 & 0.1 & 1821 & 0.7 \\
\hline Agrostis capillaris & 0.3 & 1.1 & 14 & 0.9 & 6.2 & 1.3 & 177 & 0.7 & 4.9 & 0.5 & 1647 & 0.6 \\
\hline Epilobium montanum ${ }^{\text {a }}$ & + & 0.5 & 83 & 1.4 & 0.2 & 0.7 & 1102 & 0.1 & 0.2 & 0.7 & 1525 & 0.3 \\
\hline Galium saxatile & + & 0.2 & 14 & 1.4 & 0.6 & 0.6 & 290 & 0 & 9.6 & 0.2 & 1503 & 0.4 \\
\hline Digitalis purpurea a & + & 0.5 & 6 & 1.4 & 0.2 & 1.2 & 442 & 0.3 & 0.9 & 1.4 & 1373 & 0.6 \\
\hline Stellaria alsine & + & 0.3 & 334 & 1.1 & + & 0.3 & 1022 & 0.4 & 0.2 & 1.2 & 1221 & 0.9 \\
\hline Juncus squarrosus & . & . & 271 & 0.9 & . & . & 271 & 0.4 & 0.8 & 0.9 & 973 & 1.1 \\
\hline Senecio sylvaticus a & + & 0.5 & . & . & + & 1.4 & 11 & 1.4 & 0.2 & 1.4 & 915 & 1.4 \\
\hline Cardamine flexuosa $\mathrm{b}^{\mathrm{b}}$ & + & 0.2 & 304 & 1.3 & 0.2 & 0.8 & 895 & 0.1 & + & 0.7 & 890 & 0.3 \\
\hline Epilobium ciliatum & . & . & 6 & 1.4 & + & 1.4 & 19 & 1 & 0.3 & 0 & 724 & 0.9 \\
\hline Epilobium angustifolium a & + & 0 & 102 & 1.3 & 3.4 & 0.9 & 69 & 0.3 & 9.1 & 0.2 & 655 & 0.5 \\
\hline Urtica dioica & 0.2 & 1.2 & 88 & 1.3 & 0.3 & 1.1 & 39 & 0.2 & + & 0.2 & 298 & 1.3 \\
\hline Moehringia trinervia a & + & 0.2 & 3 & 1.4 & + & 0.2 & 17 & 0 & 0.2 & 0.7 & 260 & 1.4 \\
\hline Poa trivialis & . & . & 3 & 1.4 & + & 0.3 & 14 & 1.4 & + & 0.8 & 221 & 1.2 \\
\hline Calluna vulgaris & . & . & 337 & 1 & + & 1.4 & 227 & 0.3 & 2.4 & 0.7 & 196 & 0.1 \\
\hline Carex ovalis & + & 0 & 99 & 0.9 & + & 1.4 & 17 & 0.5 & + & 0.3 & 152 & 0.6 \\
\hline Deschampsia flexuosa a & 0.3 & 1.1 & 3 & 1.4 & 4.6 & 0.5 & 3 & 1.4 & 4.6 & 0 & 99 & 1.2 \\
\hline Rumex obtusifolius & . & . & . & . & + & 1.4 & 22 & 1.4 & + & 0.7 & 66 & 1.4 \\
\hline Agrostis stolonifera & . & . & . & . & + & 0 & 8 & 1.4 & + & 0 & 55 & 0.1 \\
\hline Rubus idaeus a & 6.3 & 1.4 & 3 & 1.4 & 4.4 & 1.1 & 3 & 1.4 & 7.9 & 0.6 & 36 & 0.8 \\
\hline Luzula luzuloides a & + & 0.5 & 6 & 1.4 & 0.3 & 1.3 & 53 & 1.3 & 0.3 & 1.1 & 30 & 0.1 \\
\hline Stellaria nemorum a & . & . & . & . & . & . & . & & . & . & 28 & 1.1 \\
\hline Stellaria media & + & 0 & . & . & 0.2 & 1.2 & 3 & 1.4 & . & . & 25 & 0.8 \\
\hline Cerastium holosteoides & + & 1.4 & . & . & + & 1.4 & 8 & 0.5 & + & 0.8 & 22 & 1.4 \\
\hline Sonchus asper & . & . & . & . & . & . & 3 & 1.4 & + & 1.4 & 22 & 0.7 \\
\hline Ranunculus repens & . & . & . & . & + & 1.4 & . & . & 0.2 & 1 & 19 & 1.4 \\
\hline Rubus fruticosus agg. ${ }^{\text {a }}$ & + & 1.4 & . & . & 0.7 & 1.3 & 3 & 1.4 & 1.9 & 1 & 19 & 1.4 \\
\hline Calamagrostis epigejos a & + & 1.4 & . & . & + & 0 & . & & 2.5 & 0.2 & 11 & 0 \\
\hline Mycelis muralis a & + & 0.2 & 19 & 1.4 & + & 0.2 & 41 & 0.3 & + & 0.2 & 11 & 0 \\
\hline Carex canescens & . & . & 33 & 0.9 & + & 1.4 & 2 & 0.5 & 0.1 & 1.4 & 6 & 1.4 \\
\hline Juncus bufonius & . & . & & . & . & . & . & & . & . & 6 & 1.4 \\
\hline Veronica officinalis & + & 1.4 & 22 & 0.4 & + & 0 & 11 & 0.7 & 0.2 & 1 & 6 & 1.4 \\
\hline Betula pendula a & + & 1.4 & 14 & 0.9 & . & 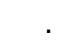 & 14 & 0.3 & + & 0.3 & 3 & 1.4 \\
\hline Hypericum humifusum & ${ }^{\circ}$ & . & 11 & 1.4 & . & . & 3 & 1.4 & . & . & 3 & 1.4 \\
\hline
\end{tabular}


Table 1 Continued

\begin{tabular}{|c|c|c|c|c|c|c|c|c|c|c|c|c|}
\hline & \multicolumn{4}{|c|}{ Control } & \multicolumn{4}{|c|}{ Selection cutting } & \multicolumn{4}{|c|}{ Clear cutting } \\
\hline & $\mathrm{C}$ & $\mathrm{CV}$ & $\mathrm{D}$ & $\mathrm{CV}$ & $\mathrm{C}$ & $\mathrm{CV}$ & $\mathrm{D}$ & $\mathrm{CV}$ & $\mathrm{C}$ & $\mathrm{CV}$ & $\mathrm{D}$ & $\mathrm{CV}$ \\
\hline Lapsana communis a & . & . & . & . & + & 1.4 & 8 & 0.5 & + & 1.4 & 3 & 1.4 \\
\hline Populus tremula a & . & . & . & . & + & 1.4 & . & . & 1.3 & 0.3 & 3 & 1.4 \\
\hline Oxalis acetosella a & 40.4 & 1.3 & 91 & 1.4 & 26.6 & 0.8 & 47 & 1.4 & 0.6 & 0.6 & . & \\
\hline Stachys sylvatica a & + & 1.4 & 28 & 1.4 & + & 1.4 & 3 & 1.4 & + & 1.4 & . & \\
\hline Vaccinium myrtillus & 2.1 & 0.4 & $\cdot$ & . & 5.6 & 0.1 & 3 & 1.4 & 2.4 & 0.2 & . & \\
\hline Carex pallescens & . & . & 8 & 0.5 & . & . & . & . & + & 0.2 & . & \\
\hline In seed bank only & & & & & & & & & & & & \\
\hline Callitriche palustris & 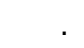 & . & . & . & . & . & . & . & . & & 66 & 1.4 \\
\hline Epilobium parviflorum & 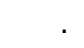 & . & . & . & . & . & 6 & 1.4 & . & & 3 & 1.4 \\
\hline Plantago major & . & . & . & . & . & . & 6 & 0 & . & & . & \\
\hline
\end{tabular}

a frequent in ancient woodland according to Zacharias (1994)

b more frequent in secondary woodland according to Zacharias (1994)

Most species showed highest densities in the organic layer and the upper $5 \mathrm{~cm}$ of the mineral soil. C. pilulifera, Juncus spec., Hypericum humifusum, Calluna vulgaris and V. officinalis also disclosed high seed densities below $5 \mathrm{~cm}$ soil depth. According to Zaccharias (1994), many species detected in the soil seed bank are frequent in ancient woodlands. Only four abundant species were more associated with secondary forests (Tables 1 and 2).

Table 2 Mean seed densities in seeds $\mathrm{m}^{-2}$ (D) and mean cover values in \% (C) and the coefficients of variation (CV) of species sampled on spruce regeneration subplots in Otterbach in 2007 on unmanaged control plots, on plots managed with selection cutting or on clear cuts. Only species found with seed densities $\geq 5 \mathrm{seed} \mathrm{m}^{-2}$ or cover values $\geq 0.1 \%$ are shown.

\begin{tabular}{|c|c|c|c|c|c|c|c|c|c|c|c|c|}
\hline \multirow[b]{3}{*}{ In vegetation only } & \multicolumn{4}{|c|}{ Control } & \multicolumn{4}{|c|}{ Selection cutting } & \multicolumn{4}{|c|}{ Clear cutting } \\
\hline & $\mathrm{C}$ & $\mathrm{CV}$ & $\mathrm{D}$ & $\mathrm{CV}$ & $\mathrm{C}$ & $\mathrm{CV}$ & $\mathrm{D}$ & $\mathrm{CV}$ & $\mathrm{C}$ & $\mathrm{CV}$ & $\mathrm{D}$ & $\mathrm{CV}$ \\
\hline & & & & & & & & & & & & \\
\hline Picea abies & 1.8 & 1.3 & . & . & 0.4 & 1.1 & . & . & 19.5 & 1.1 & r. & \\
\hline Holcus mollis a & + & 1.4 & . & . & 0.2 & 1.4 & . & . & + & 1.4 & . & \\
\hline Sorbus aucuparia a & 0.1 & 0 & . & . & 0.1 & 0 & . & . & 0.9 & 0.2 & 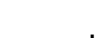 & \\
\hline Trientalis europaea $\mathrm{b}$ & 0.2 & 1.1 & . & 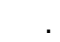 & 0.3 & 1.1 & . & . & 0.3 & 1.3 & 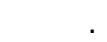 & \\
\hline Carex remota ${ }^{\text {a }}$ & 0.1 & 1.4 & . & . & ${ }^{\circ}$ & . & . & . & + & 1.4 & . & \\
\hline Galeopsis tetrahit & . & . & . & . & 0.2 & 1 & . & . & + & 0.3 & 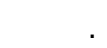 & \\
\hline Frangula alnus a & + & 0.1 & . & & 0.2 & 0.7 & . & . & + & 0 & . & \\
\hline In vegetation and seed $b$ & & & & & & & & & & & & \\
\hline Juncus effusus & . & & 7854 & 0.6 & 0.7 & 1.4 & 6056 & 1.2 & 2 & 0.7 & 24188 & 0.9 \\
\hline Carex pilulifera a & 0.1 & 0 & 1489 & 0.4 & 0.7 & 1.2 & 613 & 0.5 & 6.1 & 0.2 & 2371 & 0.2 \\
\hline Digitalis purpurea a & + & 0.3 & 10 & 0.6 & 0.7 & 1.3 & 533 & 0.9 & 0.2 & 0.7 & 2075 & 0.8 \\
\hline Galium saxatile & + & 0.2 & 3 & 1.4 & 0.7 & 0.5 & 24 & 0.5 & 8.9 & 0.5 & 1147 & 0.8 \\
\hline Agrostis capillaris & + & 0.2 & 3 & 1.4 & 0.2 & 0.9 & 3 & 1.4 & 0.9 & 0.6 & 533 & 1.3 \\
\hline Epilobium angustifolium a & + & 0.2 & 103 & 0.5 & 0.4 & 1.3 & 21 & 0.4 & 1.8 & 0 & 470 & 0.4 \\
\hline Hypericum humifusum & . & 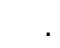 & 624 & 0.3 & + & 0 & 424 & 0.7 & + & 1.4 & 387 & 0.1 \\
\hline Luzula luzuloides a & 0.4 & 1.1 & 123 & 0.8 & + & 0.3 & 83 & 0.7 & 0.2 & 0.9 & 296 & 1.2 \\
\hline Epilobium montanum a & . & . & 26 & 0.2 & . & . & 15 & 0.7 & 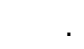 & ${ }^{\circ}$ & 163 & 1.2 \\
\hline Stellaria alsine & + & 1.4 & 43 & 0.9 & + & 1.4 & 28 & 0.2 & & & 138 & 0.1 \\
\hline Cardamine flexuosa $\mathrm{b}$ & + & 1.4 & 24 & 0.5 & + & 1.4 & 170 & 1.3 & & $0^{\circ}$ & 77 & 0.3 \\
\hline Rubus idaeus a & 1.2 & 1.4 & 19 & 0.2 & 21.7 & 0.5 & 70 & 1.4 & 10.5 & 0.1 & 39 & 0.4 \\
\hline Rubus fruticosus agg. a & 0.2 & 1.2 & 21 & 0.4 & 1.8 & 0.2 & 29 & 0.4 & 2.9 & 0.4 & 39 & 0.2 \\
\hline Moehringia trinervia a & + & 0.6 & 14 & 1.4 & 0.2 & 1.2 & 16 & 0.1 & + & 0 & 39 & 0.8 \\
\hline
\end{tabular}


Table 2 Continued

\begin{tabular}{|c|c|c|c|c|c|c|c|c|c|c|c|c|}
\hline & \multicolumn{4}{|c|}{ Control } & \multicolumn{4}{|c|}{ Selection cutting } & \multicolumn{4}{|c|}{ Clear cutting } \\
\hline & $\mathrm{C}$ & $\mathrm{CV}$ & $\mathrm{D}$ & $\mathrm{CV}$ & $\mathrm{C}$ & $\mathrm{CV}$ & $\mathrm{D}$ & $\mathrm{CV}$ & $\mathrm{C}$ & $\mathrm{CV}$ & $\mathrm{D}$ & $\mathrm{CV}$ \\
\hline Juncus bufonius & . & . & 36 & 1.4 & + & 1.4 & & . & . & . & 30 & 0.6 \\
\hline Stellaria media & + & 1.4 & 25 & 1.4 & + & 0.2 & 16 & 0.1 & . & . & 25 & 1.4 \\
\hline Poa trivialis & + & 1.4 & . & . & . & . & 6 & 0.2 & . & . & 19 & 1.4 \\
\hline Urtica dioica & + & 0.2 & 14 & 1.4 & + & 1.4 & 18 & 1 & . & . & 17 & 0.9 \\
\hline Senecio sylvaticus a & + & 0.6 & . & . & + & 1.4 & & . & + & 0 & 17 & 0.5 \\
\hline Teucrium scorodonia b & . & & . & . & + & 1.4 & . & . & 0.8 & 0 & 17 & 1.4 \\
\hline Mycelis muralis a & + & 0.6 & . & . & + & 0.8 & 4 & 1.4 & + & 1.4 & 14 & 1.4 \\
\hline Carex ovalis & + & 1.4 & 14 & 1.4 & . & . & 6 & 1.4 & + & 0.5 & 11 & 1.4 \\
\hline Deschampsia flexuosa a & 0.6 & 0.5 & 9 & 0.3 & 0.7 & 0.6 & & . & 5.9 & 0.5 & 11 & . \\
\hline Epilobium ciliatum & . & . & 7 & 1.4 & + & 1.4 & 3 & 1.4 & . & . & 8 & 1.4 \\
\hline Stellaria nemorum a & 5 & 1.4 & 108 & 1.4 & + & 1.4 & . & . & . & . & 6 & 0 \\
\hline Agrostis stolonifera & + & 1.4 & . & . & + & 0.2 & . & . & 0.1 & 1.4 & 3 & 1.4 \\
\hline Betula pendula a & . & . & 3 & 1.4 & + & 0.2 & 12 & 0.5 & 0.8 & 0 & 3 & 1.4 \\
\hline Veronica officinalis & . & . & 203 & 1.4 & . & . & 4 & 1.4 & + & 1.4 & 3 & 1.4 \\
\hline Juncus squarrosus & . & . & 6 & 0.2 & . & . & 6 & 0.2 & + & 1.4 & . & . \\
\hline Calamagrostis epigejos a & . & . & . & . & + & 1.4 & 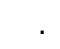 & . & 0.4 & 1.2 & . & . \\
\hline Oxalis acetosella a & 1.5 & 0.2 & 6 & 1.4 & 4.5 & 0.5 & 11 & 1.4 & 0.2 & 0.9 & . & . \\
\hline Vaccinium myrtillus & + & 0.5 & . & . & + & 0.5 & . & . & 0.9 & 1 & . & . \\
\hline Carex pallescens & . & . & 10 & 0.6 & + & 1.4 & . & . & + & 1.4 & . & . \\
\hline Impatiens parviflora $\mathrm{b}$ & 0.4 & 0.2 & 3 & 1.4 & 2.1 & 0.6 & 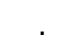 & . & + & 1.4 & . & . \\
\hline Potentilla erecta & . & . & 6 & 1.4 & . & . & . & . & + & 1.4 & . & . \\
\hline \multicolumn{13}{|l|}{ In seed bank only } \\
\hline Persicaria aviculare & . & . & . & . & . & . & . & . & . & . & 8 & 1.4 \\
\hline Isolepis setacea & . & . & 7 & 1.4 & . & . & & . & . & . & 19 & 1.4 \\
\hline Juncus bulbosus & . & . & 7 & 1.4 & . & . & . & . & . & . & . & . \\
\hline
\end{tabular}

a frequent in ancient woodland according to Zacharias (1994)

b more frequent in secondary woodland according to Zacharias (1994)

Species richness of the seed bank was also highest on clear cuts both in Neuhaus and in Otterbach. Whilst no significant differences could be detected between treatments in Otterbach, significantly more species were detected in all layers, except the deepest, on Neuhaus clear cuts compared to the control plots (Table 3). Selection cutting plots also showed a higher species richness than control plots; differences were, however, generally not significant. Highest species number in the seed bank of clear cuts corresponded with the highest species number in the vegetation under this treatment for both study sites. This is also reflected in the highest similarity indices for the clear cutting treatments. Selection cutting plots at both sites take an intermediate position, with higher values than control plots but lower than clear cuts. A significant influence of treatment, mainly clear cutting, could only be detected in Otterbach (Table 3).

In terms of species composition, very high seed densities on clear cuts correlated with higher cover values of the same species compared to control and also selection cutting plots. In general, most species with seed densities higher than 200 seeds $/ \mathrm{m}^{2}$ were also part of the aboveground vegetation. On control plots though, some species abundant in 
the seed bank were not found in the vegetation (Neuhaus: C. vulgaris, Juncus squarrosus; Otterbach: J. effusus, H. humifusum, V. officinalis; Tables 1 and 2).

Table 3 Mean species numbers found in the different soil layers, in the total soil column and in the accordant aboveground vegetation under the different treatments, the mean Sørensen Similarity index (SI) calculated regarding total soil column data and the aboveground vegetation for each treatment, results of the nested plot Anova analyzing the impact of treatment. Mean values are based on two plots per treatment. Different letters indicate significant differences between treatments according to a linear mixed effect model.

\begin{tabular}{|c|c|c|c|c|c|c|c|}
\hline & $\begin{array}{r}\text { Organic } \\
\text { layer }\end{array}$ & $0-5 \mathrm{~cm}$ & $5-10 \mathrm{~cm}$ & $10-20 \mathrm{~cm}$ & total & Veg & SI \\
\hline & & & & Neuhaus & & & \\
\hline \multirow[t]{2}{*}{ Control } & $9.5 \mathrm{a}$ & $7.4 \mathrm{a}$ & $3.0 \mathrm{a}$ & 1.9 & $12.1 \mathrm{a}$ & $20.1 \mathrm{a}$ & 0.33 \\
\hline & $( \pm 2.5)$ & $( \pm 0.6)$ & $( \pm 0.3)$ & $( \pm 0.4)$ & $( \pm 2.6)$ & $( \pm 2.1)$ & $( \pm 0.14)$ \\
\hline \multirow[t]{2}{*}{ Selection cut } & $15.5 \mathrm{ab}$ & $8.0 \mathrm{ab}$ & $6.5 \mathrm{~b}$ & 2.8 & $18.1 \mathrm{ab}$ & $26.9 a$ & 0.47 \\
\hline & $( \pm 1.5)$ & $( \pm 1.5)$ & $( \pm 0.3)$ & $( \pm 1)$ & $( \pm 2.1)$ & $( \pm 1.6)$ & $( \pm 0.03)$ \\
\hline \multirow[t]{2}{*}{ Clear cut } & $20.3 b$ & $12.6 \mathrm{~b}$ & $6.8 \mathrm{~b}$ & 4.4 & $22.0 \mathrm{~b}$ & $39.1 \mathrm{~b}$ & 0.56 \\
\hline & $( \pm 1)$ & $( \pm 1.1)$ & $( \pm 1.3)$ & $( \pm 0.1)$ & $( \pm 1)$ & $( \pm 0.1)$ & $( \pm 0.01)$ \\
\hline$F_{(2,3)}$ & 9.165 & 6.316 & 7.815 & 4.176 & 5.986 & 38.806 & 1.959 \\
\hline \multirow[t]{2}{*}{$P$} & 0.053 & 0.084 & 0.065 & 0.136 & 0.090 & 0.007 & 0.286 \\
\hline & \multicolumn{7}{|c|}{ Otterbach } \\
\hline \multirow[t]{2}{*}{ Control } & 8.5 & 6.6 & 3.4 & 4.1 & 12.7 & 15.5 & $0.27 \mathrm{a}$ \\
\hline & $( \pm 1.5)$ & $( \pm 0.9)$ & $( \pm 0.4)$ & $( \pm 1.1)$ & $( \pm 2.3)$ & $( \pm 0.5)$ & $( \pm 0.03)$ \\
\hline \multirow[t]{2}{*}{ Selection cut } & 8.3 & 6.0 & 3.3 & 4.4 & 12.2 & 22.3 & $0.30 \mathrm{a}$ \\
\hline & $( \pm 0.3)$ & $( \pm 0.7)$ & $( \pm 0.3)$ & $( \pm 0.1)$ & $( \pm 1.2)$ & $( \pm 4.3)$ & $( \pm 0.03)$ \\
\hline \multirow[t]{2}{*}{ Clear cut } & 12.4 & 9.0 & 5.3 & 4.6 & 16.1 & 22.6 & $0.49 \mathrm{~b}$ \\
\hline & $( \pm 0.9)$ & $( \pm 1.0)$ & $( \pm 0.5)$ & $( \pm 1.4)$ & $( \pm 2.3)$ & $( \pm 1.1)$ & $( \pm 0.01)$ \\
\hline$F_{(2,3)}$ & 5.260 & 3.495 & 8.096 & 0.028 & 2.257 & 2.368 & 24.724 \\
\hline $\mathrm{P}$ & 0.105 & 0.165 & 0.062 & 0.973 & 0.252 & 0.242 & 0.014 \\
\hline
\end{tabular}

Functional seed bank response to treatment in comparison to the vegetation response

Both seed bank layers, as well as the aboveground vegetation, were dominated by species of forests and open land at both sites. Clear cuts disclosed a higher proportion of mainly, or solely, open site species within the aboveground vegetation, but the lowest proportion of closed forest species compared to control plots. Selection cutting plots took an intermediate position (Fig. 3). In the seed bank though, almost no significant differences could be detected between treatments, neither in the organic layer nor in the mineral soil. However, on control plots and selection cutting plots a high proportion of open site species was determined in the mineral soil layer compared to clear cutting. This trend was most pronounced in Otterbach. Closed forest species contributed significantly less to the species richness of the vegetation on clear cuts compared to control plots. In the seed bank this species group had in general a low proportion and showed no clear pattern. 


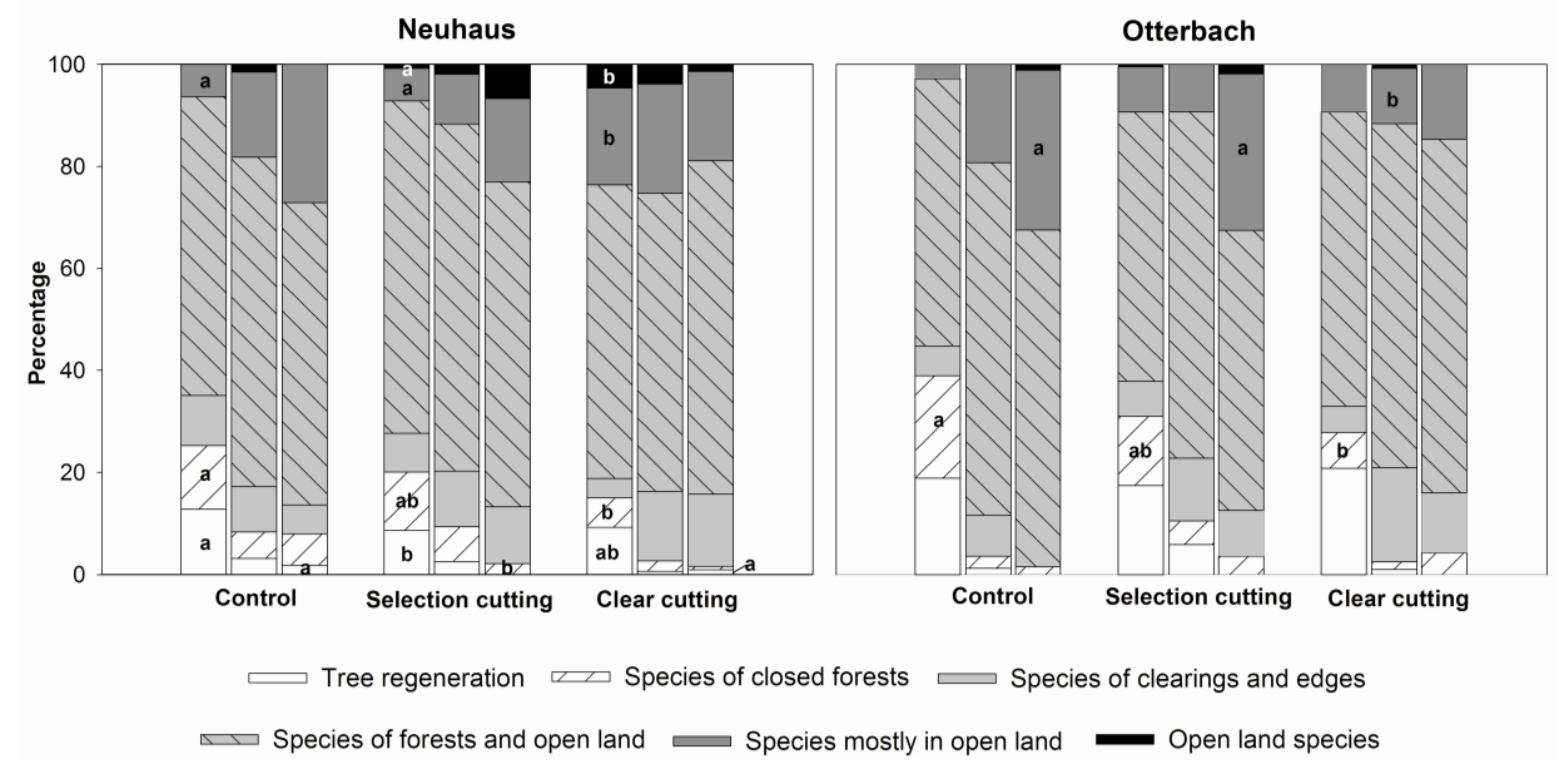

Fig. 3 Percentage contribution of forest species with different habitat preferences to total species richness in the aboveground vegetation (left column), organic layer (middle column) and the mineral soil (0-20 cm; right column) under the different treatments in Neuhaus and Otterbach. Letters indicate significant differences between treatments within one layer.

Species of clearings and edges were little represented in the vegetation in all treatments. In the seed bank though, the proportion of this species group was high after both cutting treatments compared to control plots (Fig. 3). This also applies to the proportion of ruderals within the seed banks of selection cutting and clear cut plots compared to the control plots. Competitives, although significantly more in the vegetation of clear cuts compared to the other treatments, showed no clear pattern within the seed bank. This is also true for stress-tolerators, which were, in contrast to competitives, significantly less in the vegetation on clear cuts compared to control plots (Fig. 4).

Treatment also had an influence on the percentage of different seed weight classes. At both study sites, species with very small seeds were significantly more frequent on clear cuts compared to controls. Selection cuttings again took a position in between. In the seed bank though, this pattern was not detectable. Small seeded species $(<0.5 \mathrm{mg})$ were generally the most common species group in both layers of the seed bank. Large seeded species (> $1 \mathrm{mg}$ ) showed no clear trend within the seed bank but were slightly less on clear cuts compared to selection cutting plots and control plots. The vegetation showed the same trend (Fig. 5). 


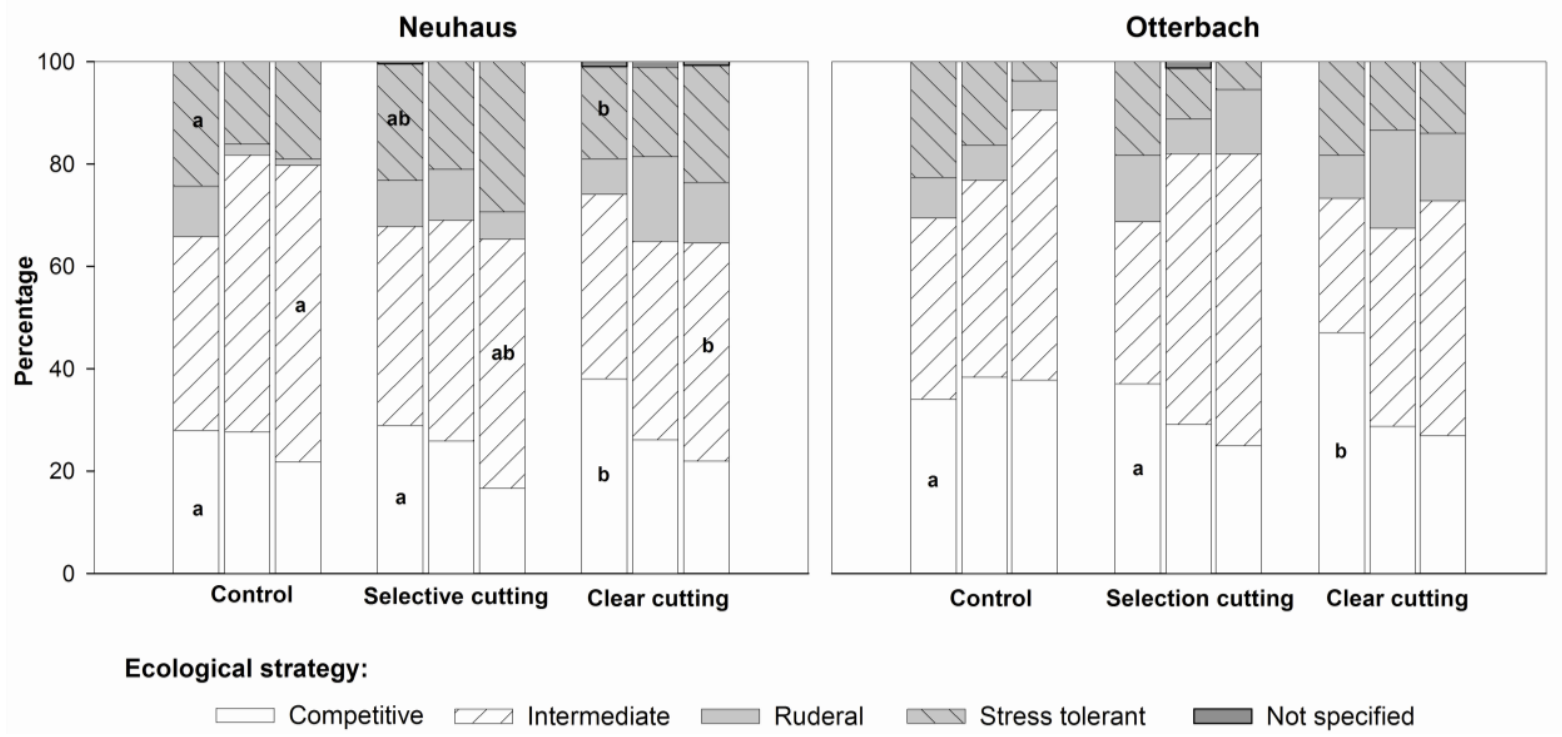

Fig. 4 Percentage contribution of species with different ecological strategies to total species richness in the aboveground vegetation (left column), organic layer (middle column) and the mineral soil (0-20 cm; right column) under the different treatments in Neuhaus and Otterbach. Letters indicate significant differences between treatments within one layer.
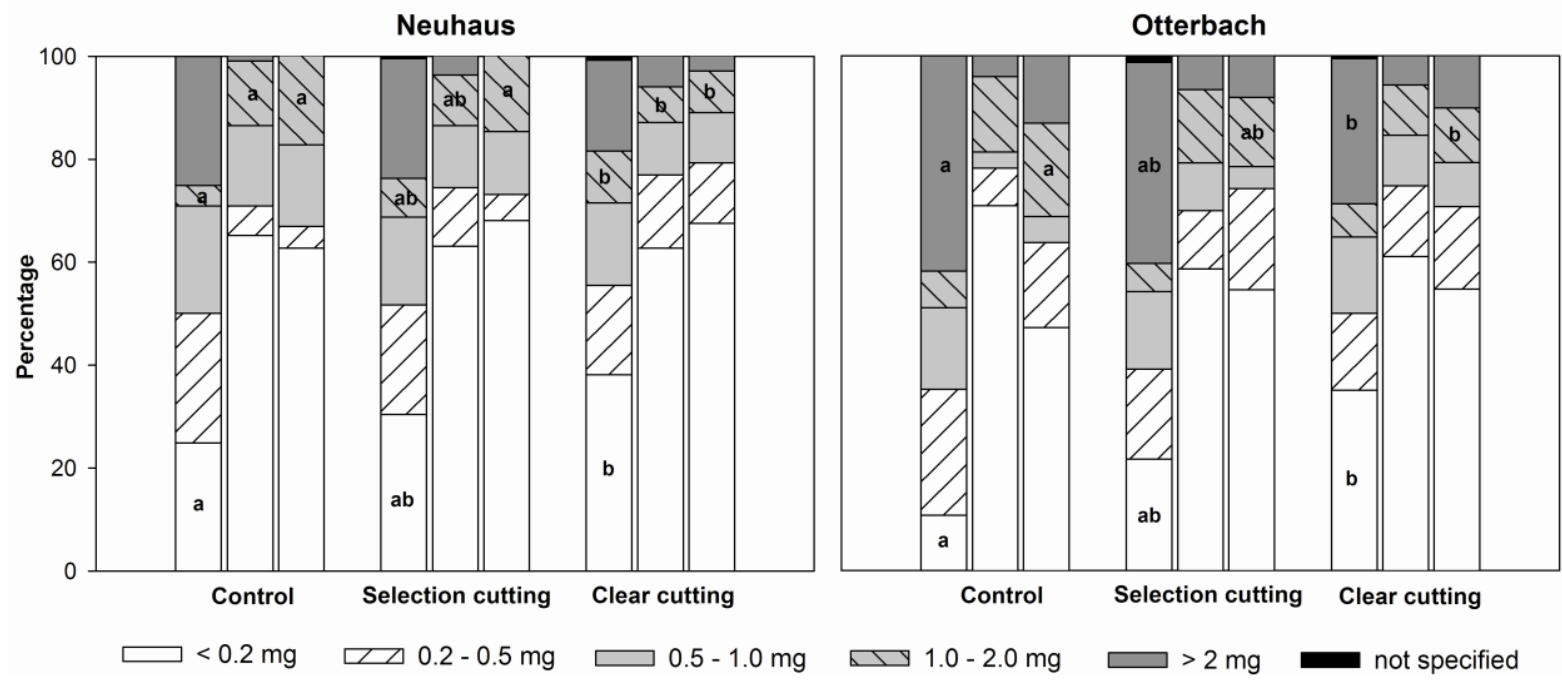

Fig. 5 Contribution of species assigned to different seed weight classes to total species richness in the aboveground vegetation (left column), organic layer (middle column) and the mineral soil $(0-20 \mathrm{~cm}$; right column) under the different treatments in Neuhaus and Otterbach. Letters indicate significant differences between treatments within one layer.

\section{Discussion}

Treatment effect on the longevity index, seed bank density and diversity

A significant increase of the mean seed longevity index in the first year after clear cutting indicates a higher proportion of species with persistent seeds, germinated from the seed bank, being part of the aboveground vegetation. This assumption can be justified by using seed banks sampled on control plots as an indication of the situation 
before clear cutting: At both study sites J. effusus and C. pilulifera dominate seed banks, which corresponds with other studies conducted in temperate forest communities $U$. effusus: Kjellsson 1992; Bossuyt et al. 2002; Berger et al. 2004; Decocq et al. 2004; C. pilulifera: Hill \& Stevens 1981). Both species can survive over 100 years in soils (Kjellsson 1992) and probably date from the time before spruce was planted. In addition, J. effusus would be widely dispersed by harvesting operations conducted over the lifespan of the forest (agestochory; Bossuyt et al. 2002). In the actual spruce plantations though, cover values are low. After clear cutting, an increase in irradiance and soil disturbance, causing accelerated litter decay and diurnal temperature fluctuations, enabled the germination of some of their seeds and led to an increase in coverage (Thompson et al. 1977; Thompson \& Grime 1983). Granström (1986) found seeds of $C$. pilulifera being able to germinate from up to $3 \mathrm{~cm}$ below the soil surface. Noticeable in this context are also the species C. vulgaris, J. squarrosus (relics of heathland vegetation in Neuhaus; Bossuyt \& Hermy 2001) and H. humifusum (Otterbach) present in high seed densities under control plots and after clear cutting in the aboveground vegetation, also contributing to the longevity index in the subsequent years after treatment.

The lower irradiance on selection cutting plots probably diminished the ability of seeds to germinate from the soil, consequently only a small and not significant increase compared to control plots could be detected in Neuhaus. The site at Otterbach though, was found to be prone to windthrow, which caused disturbance in the control and selection cutting plots and enabled the germination of persistent seeds (Heinrichs \& Schmidt 2009).

Especially the germination and subsequent flowering of the small seeded J. effusus led to its high seed accumulation in the organic layer of clear cuts and partly also in the upper mineral soil (Hölzel \& Otte 2004). Most other species contributing to the seed accumulation after clear cutting showed no large seed banks under control plots (e.g. A. capillaris, D. flexuosa, Galium saxatile), but were part of the vegetation before treatment and survived by rhizomes or root fragments (Jonsson \& Essen 1998; Heinrichs \& Schmidt 2009).

Soils of control plots showed a lower seed density in the organic layer compared to the upper mineral soil. This has been observed before and is the consequence of a higher seed predation in the humus layer and the down-washing of seeds (Hill \& Stevens 1981; Ebrecht \& Schmidt 2008). Compared to the controls, selection cutting plots in Neuhaus 
seem to accumulate seeds in the organic layer, whereas the replenishment in Otterbach is low. Neuhaus received a more recent amelioration liming compared to Otterbach, which led to the decrease of many bryophytes characteristic of acidic spruce forests (Hypnum cupressiforme, Plagiothecium curvifolium, P. undulatum, Polytrichum formosum; Rodenkirchen, 1991; Olsson \& Kellner, 2006). These species are abundant in Otterbach preventing the incorporation of seeds into the seed bank (Carleton 1982). It has to be mentioned though, that detected differences in seed densities were not recorded as significant due to a high variability caused by seed clumping. Most seeds are dispersed close to the parent plant, thus, the spatial pattern of the vegetation has a large influence on the variability of the seed density (Hill \& Stevens 1981; Kjellson 1992; Sakai et al. 2005; Zobel et al. 2007).

A persistent bryophyte layer in Otterbach can also explain similar species numbers detected in the seed bank of control and selection cutting plots, whereas in Neuhaus seed banks on selection cutting plots were more species rich than controls. At both study sites though, most species germinated from the organic layer of clear cuts. This is the result of seeds existing in the organic layer before treatment but being unable to germinate yet, seeds reaching the plots by wind dispersal (e.g. Senecio sylvaticus, Sonchus asper) from adjacent areas, or seeds being produced by flowering individuals already established on the clear cuts (e.g. Calamagrostis epigejos, D. flexuosa, E. angustifolium; Granström 1986). As germinating transient and persistent seeds contributed to the species richness of the aboveground vegetation, while already established flowering species increased the species richness of the seed bank, clear cuts showed the highest similarity between seed bank and aboveground vegetation composition. This is a well documented phenomenon after severe disturbance (Pickett \& McDonnell 1989; Decocq et al. 2004; van Calster et al. 2008; Dölle \& Schmidt 2009).

Comparing both study sites, the seed bank at Neuhaus was more species rich in all layers, as was the understorey vegetation in general. The more frequent liming in Neuhaus influenced the herb layer composition and consequently the seed source of the soil seed bank (Heinrichs \& Schmidt 2009).

Is there a risk of weed expansion from the seed bank?

Seed banks of temperate forest communities often contain high densities of early successional, light demanding competitive or ruderal species, which can delay the secondary succession process after germination (Bossyt et al. 2002; Berger et al. 2004, 
Sakai et al. 2005). In particular, a large expansion of graminoids (Calamagrostis epigejos, but also D. flexuosa; Prach \& Pyšek 1999) and Rubus species is dreaded for stand development as it can prevent natural regeneration from colonizing and accommodate seed or root predating rodents (Schmidt et al. 1996; Schreiner et al. 2000; Romagosa \& Robison 2003). An increase in nutrient levels after harvesting operations can even increase the expansion of competitive strategists. Our results show a significantly greater percentage of competitive species within the aboveground vegetation on clear cuts compared to the other treatments, whilst the seed bank disclosed no clear pattern at both sites. Competitives were however, detectable in the soils of control plots (e.g. Juncus spec., Epilobium angustifolium, Urtica dioica), which germinated from the seed bank after soil disturbance. Other species have reached the plots by short or long distance wind dispersal (e.g. Picea abies, Betula pendula, Populus tremula) as their detected seed densities were zero or very low. C. epigejos was as well not detected in seed banks of control plots. This species has a deep root system and has thus survived vegetatively (Rebele \& Lehmann 2001). Seed accumulation following flowering on clear cuts, as seen in this study, is however low, and thus the risk of expansion mainly results from surviving rhizomes expanding rapidly and not from the seed bank. Although Rubus species mainly colonize plots by germination from the seed bank (Fischer 1987; Hughes \& Fahey 1990; Mayer et al. 2004), the low seed densities found under all treatments in the Solling, and the frequent and abundant occurrence in the vegetation before treatment, suggest a vegetative expansion of these species as well (Heinrichs \& Schmidt 2009). Seeds of Rubus species are often classified as long-term persistent (Kjellson 1992; Berger et al. 2004), but after 100 years under spruce plantations most seeds have probably lost viability (Warr et al. 1994; Bossuyt et al. 2002). In contrast to C. epigejos though, Rubus species have the potential to accumulate a persistent seed bank after flowering (see mainly Otterbach; Kjellsson 1992; Hyatt \& Casper 2000). Thus, though not abundant in the seed bank before treatment, the accumulation afterwards can influence the upcoming regeneration, particularly following recurrent disturbance regimes such as selection cutting.

At both study sites vegetation and seed banks comprised a relatively low proportion of ruderal species (Decocq et al. 2004). However, in particular annuals were mainly present in the first year after clear cutting (Heinrichs \& Schmidt 2009) and have probably led to an increase in the species richness of this species group in the organic layer. Selection cutting increased the percentage of ruderal species in the organic layer 
compared to the control plots also slightly in Neuhaus, but not yet in Otterbach, due to the dense bryophyte cover. However, an earlier study showed that the species numbers of ruderals remained stable within the vegetation over a period of four years following selection cutting (Heinrichs \& Schmidt 2009), leaving the possibility of a seed bank formation at later stages after recurrent disturbance (Hyatt \& Casper 2000).

\section{Can the seed bank potentially contribute to the future forest community?}

Several authors have mentioned the low significance of forest seed banks for the regeneration of a forest community after disturbance (e.g. Pickett \& McDonnell 1989; Decocq et al. 2004; Zobel et al. 2007). Particularly under a coniferous canopy, Augusto et al. (2001) reported the disappearance of some typical forest species from the seed bank due to canopy effects on soil properties. On the contrary, other authors found an occurrence of late-successional forest species within seed banks (Buckley et al. 1997; Godefroid et al. 2006). Results from the Solling show a significantly lower proportion of closed forest species in the vegetation of clear cuts compared to control plots, and concurrently, a generally very low proportion of this species group in the seed bank under all treatments. On the other hand, the proportion of open site species is high in seed banks under a closed canopy and lower on clear cuts (in particular Otterbach), indicating a germination of open site species after clear cutting. The low proportion of species with large seeds, often necessary for a successful recruitment under a dense canopy or litter layer (Eriksson 1995), underlines the scarcity of closed forest species in the seed bank, whereas small seeded species, typical for open sites, are dominant throughout the investigated soil layers and treatments. In addition, O. acetosella was only found in the seed bank when abundant in the vegetation, indicating a transient seed bank. All these findings support the assumption of a low effectiveness of the seed bank for a forest understorey recovery. However, both vegetation and seed bank at both study sites are dominated by species appearing in forests, as well as at open sites. Among others, C. pilulifera and Luzula luzuloides are classified to this group. Both species are characteristic for acidic beech forests, the potential natural woodland community of the Solling (Ellenberg et al. 1986), and are frequent in ancient woodlands of the low mountain ranges in Germany (Zacharias 1994). Both species accumulate a persistent seed bank (longevity index of 0.8; Kleyer et al. 2008) after clear cutting and can consequently contribute to the future forest community. Also other species present in the Solling seed banks were exclusively detected in ancient forest seed banks before 
(Hypericum humifusum, Stachys sylvatica; Bossuyt \& Hermy 2001). Species of clearings and edges (e.g. the ancient woodland species D. purpurea, S. sylvaticus) contribute more to the species richness of the seed bank following either treatment compared to controls. Clearings and edges are frequently occurring habitats within forests, and thus, also species of this species group can later contribute to the forest community (Wulf 1994).

\section{Conclusion}

Our results indicate a contribution of the soil seed bank to the aboveground vegetation after clear cutting, and to a lesser degree, also after selection cutting during the initial phase of a Norway spruce stand conversion. Thereby, J. effusus and C. pilulifera are the most important species. Most other species though, including very competitive ones like C. epigejos or R. idaeus, have to rely on an effective dispersal mechanism or their ability to propagate vegetatively as their seeds are either transient or have not survived 100 years under spruce plantation. Their success after both management regimes depends on their presence before treatment and survival afterwards. In addition, Rubus idaeus and other species as well (e.g. A. capillaris in Neuhaus), are able to accumulate a persistent seed bank after both management regimes. This might facilitate a site preemption and impede the establishment of tree regeneration, particularly following recurrent disturbance regimes such as selection cutting. Thus, the composition of the understorey vegetation should be a major selection criterion when choosing stands for conversion. Furthermore, sites with already established deciduous tree regeneration (e.g. Acer pseudoplatanus, Fagus sylvatica) might be able to prevent the large vegetative expansion of competitive strategists after selection cutting. After clear cutting, the colonisation of wind dispersed pioneer trees might repress shade-intolerant ruderal and competitive strategists. Pioneer trees can also decrease the extirpation risk of closed forest species like 0 . acetosella, after clear cutting. Closed forest species have transient seed banks, and thus depend on maintaining small refuge populations under shrubs or pioneer trees on clear cuts. The dispersal from populations in the direct vicinity is also important. Thus, a small scale mosaic of clear cuts, managed forests maintaining a closed canopy and largely unmanaged stands is important to maintain species with limited dispersal ability.

However, though not rich in closed forest species, our results show that the seed bank may be important in maintaining the characteristic vegetation of ancient acidic forests, 
which has survived centuries of forest management and will also survive the challenge of conversion in the near future.

\section{Acknowledgements}

We would like to thank Andrea Bauer, Andreas Parth, Heiko Rubbert and Markus Bernhardt-Römermann for help during field and laboratory work and Ruth Gilbert for language correction.

\section{References}

Augusto, L., Dupouey, J.-L., Picard, J.-F. \& Ranger, J. 2001. Potential contribution of the seed bank in coniferous plantations to the restoration of native deciduous forest vegetation. Acta Oecologica 22: 87-98.

Bekker, R.M., Bakker, J.P., Grandin, U., Kalamees, R., Milberg, P., Poschlod, P., Thompson, K. \& Willems, J.H. 1998. Seed size, shape and vertical distribution in the soil: indicators of seed longevity. Functional Ecology 12: 834-842.

Berger, T.W., Sun, B. \& Glatzel, G. 2004. Soil seed banks of pure spruce (Picea abies) and adjacent mixed species stands. Plant and Soil 264: 53-67.

Bormann, F.H. \& Likens, G.E. 1994. Pattern and process in a forested ecosystem. Springer, New York.

Bossuyt, B. \& Hermy, M. 2001. Influence of land use history on seed banks in European temperate forest ecosystems: a review. Ecography 24: 225-238.

Bossuyt, B., Heyn, M. \& Hermy, M. 2000. Concentrating samples estimates a larger seed bank density of a forest soil. Functional Ecology 14: 766-767.

Bossuyt, B., Heyn, M. \& Hermy, M. 2002. Seed bank and vegetation compositions of forest stands of varying age in central Belgium: consequences for regeneration of ancient forest vegetation. Plant Ecology 162: 33-48.

Buckley, G.P., Howell, R. \& Anderson, M.A. 1997. Vegetation succession following ride edge management in lowland plantations and woods. 2 . The seed bank resource. Biological Conservation 82: 305-316.

Carleton, T.J. 1982. The pattern of invasion and establishement of Picea mariana (Mill.) BSP. into subcanopy layers of Pinus banksiana Lamb. dominated stands. Canadian Journal of Forest Research 12: 973-984. 
Decocq, G., Valentin, B., Toussaint, B., Hendoux, F., Saguez, R. \& Bardat, J. 2004. Soil seed bank composition and diversity in a managed temperate deciduous forest. Biodiversity and Conservation 13: 2485-2509.

Diaci, J. 2002. Regeneration dynamics in a Norway spruce plantation on a silver fir-beech forest site in the Slovenian Alps. Forest Ecology and Management 161: 27-38.

Dölle, M. \& Schmidt, W. 2009. The relationship between soil seed bank, above-ground vegetation and disturbance intensity on old-field successional permanent plots. Applied Vegetation Science 12: 415-428.

Ebrecht, L. \& Schmidt, W. 2008. Bedeutung der Bodensamenbank und des Diasporentransports durch Forstmaschinen für die Entwicklung der Vegetation auf Rückegassen. Forstarchiv 79: 91-105.

Ellenberg, H., Mayer, R. \& Schauermann, J.1986. Ökosystemforschung - Ergebnisse des Sollingprojekts. Ulmer, Stuttgart.

Eriksson, 0. 1995. Seedling recruitment in deciduous forest herbs: the effects of litter, soil chemistry and seed bank. Flora 190: 65-70.

Fischer, A. 1987. Untersuchungen zur Populationsdynamik am Beginn von Sekundärsukzessionen. Die Bedeutung von Samenbank und Samenniederschlag auf die Wiederbesiedlung vegetationsfreier Flächen in Wald- und Grünlandgesellschaften. Dissertationes Botanicae 110: 1-234.

Gilliam, F.S. 2007. The ecological significance of the herbaceous layer in temperate forest ecosystems. Bioscience 57: 845-858.

Godefroid, S., Rucquoij, S. \& Koedam, N. 2005. To what extent do forest herbs recover after clearcutting in beech forests? Forest Ecology and Management 210: 39-53.

Godefroid, S., Phartyal, S.S. \& Koedam, N. 2006. Depth distribution and composition of seed banks under different tree layers in a managed temperate forest ecosystem. Acta Oecologica 29: 283-292.

Granström, A. 1982. Seed banks in five boreal forest stands originating between 1810 and 1963. Canadian Journal of Botany 60: 1815-1821.

Granström, A. 1986. Seed banks in forest soils and their role in vegetation succession after disturbance. Dissertation of the Swedish University of Agricultural Science.

Hannerz, M. \& Hånell, B. 1997. Effects on the flora in Norway spruce forests following clearcutting and shelterwood cutting. Forest Ecology and Management 90: 29-49. 
Heinrichs, S. \& Schmidt, W. 2009. Short-term effects of selection and clear cutting on the shrub and herb layer vegetation during the conversion of even-aged Norway spruce stands into mixed stands. Forest Ecology and Management 258: 667-678.

Hill, M.O. \& Stevens, P.A. 1981. The density of viable seed in soils of forest plantations in upland Britain. Journal of Ecology 69: 693-709.

Hölzel, N. \& Otte, A. 2004. Assessing soil seed bank persistence in flood-meadows: The search for reliable traits. Journal of Vegetation Science 15: 93-100.

Hughes, J.W. \& Fahey, T.J. 1990. Colonization dynamics of herbs and shrubs in a disturbed northen hardwood forest. Journal of Ecology 79: 605-616.

Huston, M.A. 1994. Biological diversity: the coexistence of species on changing landscapes. University Press, Cambridge.

Hyatt, L.A. \& Casper, B.B. 2000. Seed bank formation during early secondary succession in a temperate deciduous forest. Journal of Ecology 88: 516-527.

Jonsson, B.G. \& Esseen, P.-A. 1998. Plant colonisation in small forest-floor patches: importance of plant group and disturbance traits. Ecography 21: 518-526

Kjellsson, G. 1992. Seed banks in Danish deciduous forests: species composition, seed influx and distribution pattern in soil. Ecography 15: 86-100.

Kleyer, M., Bekker, R.M., Knevel, I.C., Bakker, J.P., Thompson, K., Sonnenschein, M., Poschlod, P., van Groenendael, J.M., Klimeš, L., Klimešová, J., Klotz, S., Rusch, G.M., Hermy, M., Adriaens, D., Boedeltje, G., Bossuyt, B., Dannemann, A., Endels, P., Götzenberger, L., Hodgson, J.G., Jackel, A.-K., Kühn, I., Kunzmann, D., Ozinga, W.A., Römermann, C., Stadler, M., Schlegelmilch, J., Steendam, H.J., Tackenberg, O., Wilmann, B., Cornelissen, J.H.C., Eriksson, O., Garnier, E. \& Peco, B. 2008. The LEDA traitbase: a database of life-history traits of the Northwest European flora. Journal of Ecology 96: 1266-1274.

Klotz, S., Kühn, I. \& Durka, W. 2002. BiolFlor - Eine Datenbank mit biologischökologischen Merkmalen zur Flora von Deutschland. Schriftenreihe Vegetationskunde 38: 1-334.

Lautenschlager, R.A. 1997. Effects of perturbations and stimulants on red rasberry (Rubus idaeus L.) seed germination. Forest Chronicle 73: 453-457.

Mayer, P. Abs, C. \& Fischer, A. 2004. Colonisation by vascular plants after soil disturbance in the Bavarian forest - key factors and relevance for forest dynamics. Forest Ecology and Management 188: 279-289. 
NMELF (Niedersächsisches Ministerium für Ernährung, Landwirtschaft und Forsten) 1996. Waldentwicklung Solling - Fachgutachten. Schriftenreihe Waldentwicklung in Niedersachsachsen 5: 1-149.

Olsson, B.A. \& Kellner, O. 2006. Long-term effects of nitrogen fertilization on ground vegetation in coniferous forests. Forest Ecology and Management 237: 458-470.

Otto, H.-J. 1995. Die Verwirklichung des LÖWE-Regierungsprogramms. AFZ/Der Wald 50: 1028-1031.

Pickett, S.T.A. \& McDonnell, M.J. 1989. Seed bank dynamics in temperate deciduous forest. In: Leck, M.A., Parker, V.T., Simpson, R.L. (eds.) Ecology of soil seed banks, pp. 123-147. Academic Press, San Diego.

Prach, K. \& Pyšek, P. 1999. How do species dominating in succession differ from others? Journal of Vegetation Science 10: 383-392.

Qi, M. \& Scarratt, J.B. 1998. Effect of harvesting method on seed bank dynamics in a boreal mixedwood forest in northwestern Ontario. Canadian Journal of Botany 76: 872-883.

Rebele, F. \& Lehmann, C. 2001. Biological Flora of Central Europe: Calamagrostis epigejos (L.) Roth. Flora 196: 325-344.

Rodenkirchen, H. 1991. Entwicklung der Waldbodenvegetation auf den Versuchsflächen des Höglwald-Experiments im Beobachtungszeitraum 1983-1989. Forstwissenschaftliche Forschung 39: 74-86.

Romagosa, M.A. \& Robison, D.J. 2003. Biological constraints on the growth of hardwood regeneration in upland Piedmont forests. Forest Ecology and Management 175: 545561.

Rothe, A., Huber, C., Kreutzer, K. \& Weis, W. 2002. Deposition and soil leaching in stands of Norway spruce and European beech: results from the Höglwald research in comparison with other European case studies. Plant and Soil 240: 33-45.

Rydgren, K., Hestmark, G. \& Økland, R.H. 1998. Revegetation following experimental disturbance in a boreal old-growth Picea abies forest. Journal of Vegetation Science 9: 763-776.

Sakai, A., Sato, S., Sakai, T., Kuramoto, S. \& Tabuchi, R. 2005. A soil seed bank in a mature conifer plantation and establishement of seedlings after clear cutting in southwest Japan. Journal of Forest Research 10: 295-304. 
Schmidt, M., Ewald, J., Fischer, A., Oheimb, G.V., Kriebitzsch, W.-U., Ellenberg, H. \& Schmidt, W. 2003. Liste der in Deutschland typischen Waldgefäßpflanzen. Mitteilungen der Bundesforschungsanstalt für Forst-Holzwirtschaft 212: 1-32.

Schmidt, W., Pfirrmann, H. \& Brünn, S. 1996. Zur Ausbreitung von Calamagrostis epigejos in niedersächsischen Kiefernwäldern. Forst und Holz 51, 369-372.

Schreiner, M., Bauer, E.-M. \& Kollmann, J. 2000. Reducing predation of conifer seeds by clear-cutting Rubus fruticosus agg. in two montane forest stands. Forest Ecology and Management 126: 281-290.

Spiecker, H. 2003. Silvicultural management in maintaining biodiversity and resistance of forests in Europe - temperate zone. Journal of Environmental Management 67: 5565.

Stöcklin, J. \& Fischer, M. 1999. Plants with longer lived seeds have lower local extinction rates in grassland remnants 1950-1985. Oecologia 120: 539-543.

Thompson, K. \& Grime, J.P. 1983. A comparative study of germination responses to diurnally-fluctuating temperatures. Journal of Applied Ecology 20: 141-156.

Thompson, K., Grime, J.P. \& Mason, G. 1977. Seed germination in response to diurnal fluctuations of temperature. Nature 267: 147-149.

Van Calster, H., Chevalier, R., Van Wyngene, B., Archaux, F., Verheyen, K., Hermy, M. 2008. Long-term seed bank dynamics in a temperate forest under conversion from coppice-with-standards to high forest management. Applied Vegetation Science 11: 251-260.

Van der Valk, A.G. 1992. Establishment, colonization and persistence. In: Glenn-Lewin, D.C., Peet, R.K., Veblen, T.T. (eds.) Plant succession - theory and prediction, pp. 60102. Chapman \& Hall, London.

Van der Valk, A.G. \& Pederson, R.L. 1989. Seed banks and the management and restoration of natural vegetation. In: Leck, M.A., Parker, V.T., Simpson, R.L. (eds) Ecology of soil seed banks, pp. 329-346. Academic Press, San Diego.

Warr, J.S., Kent, M. \& Thompson, K. 1994. Seed bank composition and variability in five woodlands in southwest England. Journal of Biogeography 21: 151-168.

Wisskirchen, R., Haeupler, H. 1998. Standardliste der Farn- und Blütenpflanzen Deutschlands. Ulmer, Stuttgart.

Wulf, M. 1994. Plant species as indicators of ancient woodland in northwestern Germany. Journal of Vegetation Science 8: 635-642. 
Wulf, M. 2003. Forest policy in the EU and its influence on the plant diversity of woodlands. Journal of Environmental Management 67: 15-25.

Zacharias, D. 1994. Bindung von Gefäßpflanzen an Wälder alter Waldstandorte im nördlichen Harzvorland Niedersachsens - ein Beispiel für die Bedeutung des Alters von Biotopen für den Pflanzenartenschutz. NNA-Berichte 3: 76-88.

Zobel, M, Kalamees, R., Püssa, K., Roosaluste, E. \& Moora, M. 2007. Soil seed bank and vegetation in mixed coniferous forest stands with different disturbance regimes. Forest Ecology and Management 250: 71-76. 


\title{
Chapter 6
}

\author{
Synthesis
}
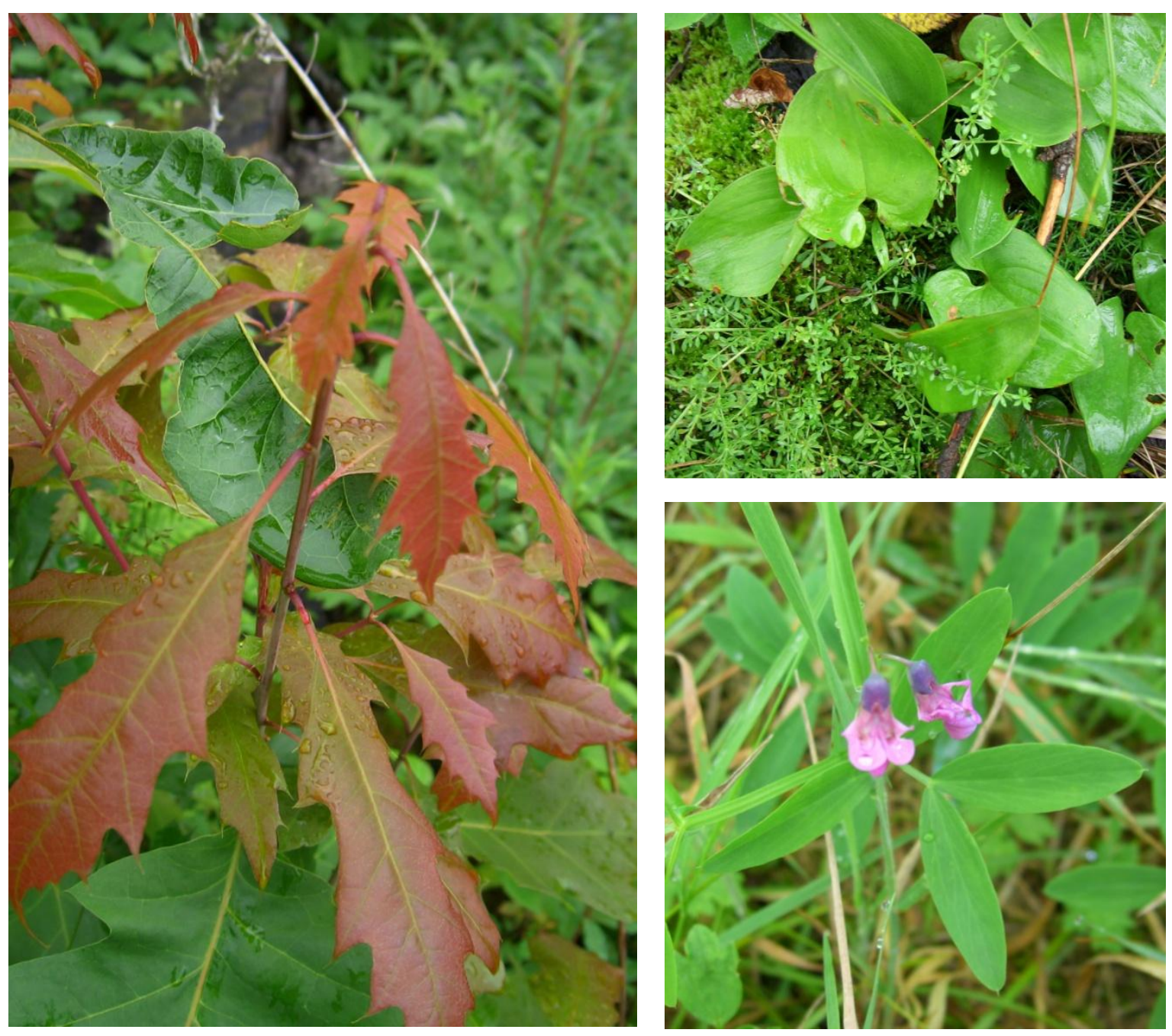
Left: natural regeneration of Quercus rubra; Top right: Maianthemum bifolium surrounded by Galium saxatile; Bottom right: Lathyrus linifolius. Photographs taken by Steffi Heinrichs. 


\section{General remarks}

The main aim of the thesis on hand was to assess the response of the understorey vegetation of Norway spruce stands in terms of diversity and function to the forest harvesting regimes selection cutting and clear cutting. Single tree selection cutting, that is thought to mimic natural disturbances, is the preferred method that will widely be used for conversion of even-aged Norway spruce stands into mixed stands in Lower Saxony. Such natural disturbance regime, however, applies mainly to beech forests, which would occur naturally across Germany because of its high competitive ability (Leuschner 1998). The disturbance regime in such natural beech forests is mainly characterized by small scale gaps due to the breakdown of single old trees (Knapp \& Jeschke 1991; Meyer et al. 2003). Natural spruce forests, on the other hand, which are abundant in the boreal zone and in montane regions of the temperate zone, are often affected by catastrophic windthrow or insect attacks (Homann \& Engels 1991; Ulanova 2000; Fischer et al. 2002; Firm et al. 2009) that would rather resemble a more severe harvesting regime like clear cutting. As such disturbance is in general perceived negatively, clear cutting will be avoided during spruce conversion at most sites. The present work could, however, detect no overall negative effects of small scale clear cuttings regarding the understorey functions mentioned in Chapter 1. The following Chapter summarizes and discusses the main findings, presented in the Chapters 3 through 5 , in order to give implications for a future conversion management.

\section{Treatment effects on understorey vegetation characteristics}

Forest biodiversity

Both investigated silvicultural treatments induced clear changes in vegetation characteristics during the first four to five years following harvesting operations. Mainly, the increased light availability triggered these developments that are displayed in changes in total plant species richness, diversity within different functional groups, as well as in changes in species and functional group abundance. An increase in plant species diversity, detected for both management regimes, is reflected in a rise in competitive forest generalists, open site species as well as in tree regeneration with clear cutting plots showing in general significantly higher numbers three years after harvesting operations than selection cutting plots. This provides support for the speciesenergy hypothesis, basically predicting that local species diversity increases with energy availability (Rosenzweig 1995). Conversely, species with a short life-cycle were slightly 
longer persistent after selection cutting. Thus, the higher resource availability, in particular regarding light, favoured superior competitors after the initial disturbance effects caused by clear cutting abated (i.e. bare mineral soil favouring generally superior colonizers such as ruderal annuals or open site species; McIntyre et al. 1995). In contrast, recurrent small disturbances following selection cutting (single tree falls, falling branches) kept superior colonizers on the plots (Kondoh 2001). However, four years after clear cutting still no decrease in species numbers was detectable as a consequence of the dominance of a few species; on the contrary, many competitors, including Rubus species, but also upcoming pioneer trees, offered shelter for shadetolerant herbs and forest specialists that were by this means able to persist. Persistent forest vegetation was found by several authors examining clear cuts or different gap sizes following storm events (e.g. Zobel 1989: for Estonian clear cuts of uneven-aged forests; Kompa \& Schmidt 2003: for large gaps in acidic beech forests in Germany; Degen et al. 2005: for gaps between $250 \mathrm{~m}^{2}$ to 1.8 ha size in acidic beech forests in France). This persistence is crucial as the present work, like several other studies before (e.g. Bossuyt et al. 2002; Decocq et al. 2004a; Zobel et al. 2007), noted the inability of forest specialists, characterised by heavy seeds, to produce a persistent seed bank. In addition, the number of closed forest species is in general low in natural acidic beech forests (Ellenberg 1996), thus, their maintenance after disturbance is all the more important. On the Solling plots Oxalis acetosella, Festuca gigantea and Moehringia trinervia, but in very low frequencies also Maianthemum bifolium and Milium effusum have been persistent.

Despite changes in plant species diversity, the development after both treatment types was mainly characterized by abundance changes of species being present in the intact forest. Hence, vegetation development after harvesting depends on the survival of plant species, which are then able to spread under the changed environmental conditions. This parallels the concept of the initial floristic composition proposed by Egler (1954), where species present at the time of pasture abandonment, either active or dormant, accounted for $95 \%$ of the subsequent vegetation development. On Solling clear cuts an influence of the soil seed bank could be detected for Carex pilulifera and Juncus effusus. Most other species propagated vegetatively (Deschampsia flexuosa, Epilobium angustifolium, Galium saxatile, Agrostis capillaris, Rubus idaeus) or reached the plots through wind dispersal from adjacent areas (e.g. E. angustifolium, E. ciliatum, Senecio sylvaticus). After selection cutting especially $R$. idaeus increased steadily in abundance 
supporting results by Hannerz \& Hånell (1993; 1997), by Degen et al. (2005) and by von Oheimb \& Härdtle (2009). Though germination from the seed bank was proposed by Mayer et al. (2004), the expansion of $R$. idaeus at the study sites was mainly caused by vegetative propagation as the detected seed density in the soil of 100-year-old spruce plantations was low. Consequently, the existing ground vegetation should be a major selection criterion when choosing stands for conversion and the intensity of harvesting operations.

\section{Competition for tree regeneration}

As the fitness and performance of natural and planted tree regeneration was not measured in the framework of the present work, the success of regeneration can only be assessed by its mean species richness per subplot and its contribution to total understorey abundance.

With about $20 \%$, the tree regeneration contributed significantly more to total vascular plant species abundance on clear cuttings in 2007 than on selection cutting or control plots. Also the mean richness of tree species was significantly higher on clear cuts compared to the other treatments. In addition the mean cover of single species was in general higher on clear cuttings than on selection cutting plots especially regarding the unplanted pioneer trees, but also considering planted species (Fagus sylvatica, Pseudotsuga menziesii). Tree regeneration on clear cuts also contributed up to $50 \%$ and higher to the total understorey nitrogen content in 2008 on spruce regeneration subplots. The proportion was much less after selection cutting.

Hence, the results give no indication for a competitive exclusion of tree species on clear cuts by graminoids or Rubus-species, despite their expansion after disturbance. This contradicts Kompa \& Schmidt (2003), who found a large expansion of pioneer shrubs but a lack in pioneer trees on large areas affected by windthrow on acidic soils. Conversely, Donoso \& Nyland (2006) summarized many studies conducted in temperate deciduous forests at mesic sites showing only a low degree of interference of Rubus species with desired hardwood species. These authors also mention the work by Horsely \& Marquis (1983), who found no effect of Rubus species on the establishment of pioneer trees in North American cherry-maple stands after shelterwood cutting. However, on selection cutting plots in this study the establishment of tree species seemed to be deterred. The large vegetative expansion, especially of $R$. idaeus, but also a smaller number of available colonisation sites (in part by a persistent bryophyte layer), and an 
only patch wise increase in light availability can be reasons for this. Particularly the competition from Rubus species can become much more important in the future with the recurrent disturbance (e.g. a 5-year-cutting-cycle as planned in the Solling) that is connected with a selection cutting regime. The formation of a persistent seed bank observed for R. idaeus can be an indication for this. Decocq et al. (2004b) reported the large dominance of $R$. fruticosus in 30-year-old selection cutting stands, due to increasing light levels. This dominance caused a decrease in species richness of herb and shrub layer. Similar concerns about partial harvesting were mentioned by Burke et al. (2008) for the long-term perspective. Recurrent canopy opening can also have a positive effect on other high competitive species like Pteridium aquilinum (Quinby 2000) or Calamagrostis epigejos that only increased slowly and locally after the first cutting cycle on the Solling plots. Hence, an early integration of natural and planted regeneration in selection cutting stands is important to give tree species a growth advantage before subsequent cutting procedures favour the further expansion of competitive plant species.

\section{Nitrogen cycling}

Estimated aboveground biomass values as well as nitrogen contents showed a clear increase after both treatments. Highest values were reached on clear cuts over the study period, including the first vegetation period following harvesting. Hence, the vegetation was able to compensate the mechanical disturbance (Fig. 1).

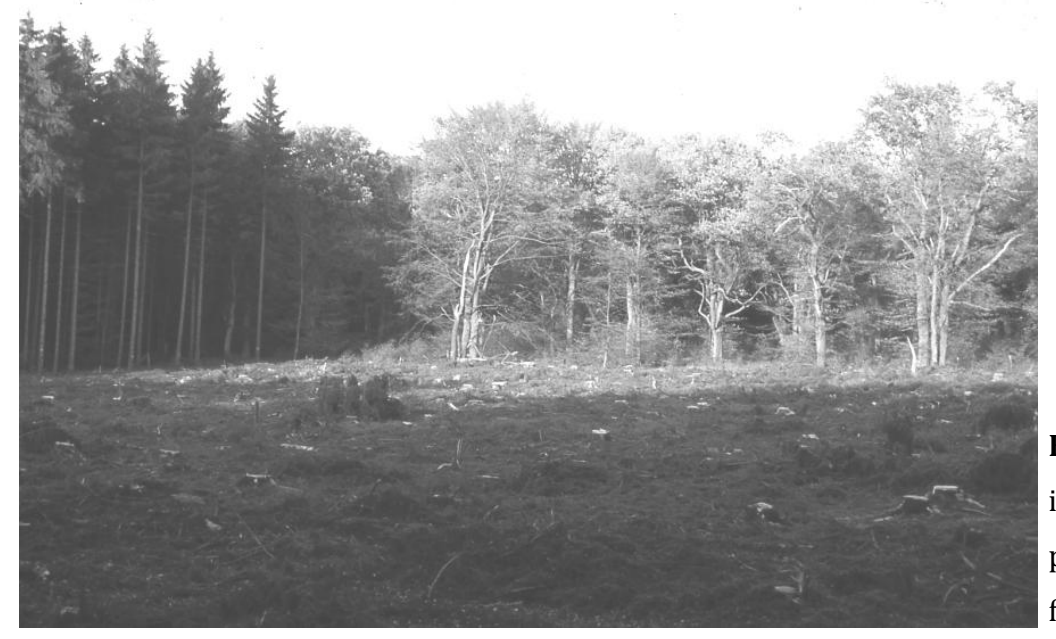

Fig. 1: Disturbance due to clear cutting in Otterbach, in the background an old protected oak forest indicating the former land use (Photo: W. Schmidt)

Forest generalists, occuring in forests but also in open site communities (e.g. D. flexuosa, D. purpurea, E. angustifolium), are often part of the understorey vegetation of Norway spruce stands (Weckesser 2003). These species are growth-limited due to the low light 
availability under a closed canopy (Al-Mufti et al. 1977; Strengbom et al. 2004) and are able to expand after canopy opening, if surviving. Especially on clear cuts, this expansion in coverage is connected with a higher degree of flowering (e.g. A. capillaris and D. flexuosa: mainly infertile in closed forests) and a larger height growth (e.g. D. purpurea: often only present with a ground rosette in closed forests) making a higher nutrient uptake necessary (Tilman 1988). Several indications for a higher nitrogen availability were detected after clear cutting: First to mention is the response of the understorey vegetation. The mean specific leaf area (SLA; proposed as a functional marker by Garnier et al. (2004)) and the importance of herbaceous species (mainly herbs and graminoids) weighted by biomass respectively nitrogen content increased, what suggests a fast resource aquisition (Aerts \& Berendse 1988; Reich et al. 1992; Garnier et al. 2004; Graves et al. 2006). Olchev et al. (2009) found a temperature increase at $10 \mathrm{~cm}$ soil depth compared to the control stands, which is, in combination with a higher water content (Matejek et al. 2008), often connected with a faster decomposition of organic matter and nitrogen mineralisation (Vitousek et al. 1979; Covington 1981; Bagherzadeh et al. 2008). C/N ratios were tighter soon after clear cutting compared to the situation before (Klinck et al. 2007) and lowest on clear cuts compared to the other treatments four years after harvesting. The reduction in organic layer thickness implies that the forest floor is the source for available nitrogen (Legout et al. 2009).

A similar, though slighter, response in terms of plant traits found after selection cutting suggests an effect on nitrogen availability also after such moderate disturbance, although Prescott et al. (2003) found no indication for this following a single tree selection harvest. A tighter $\mathrm{C} / \mathrm{N}$ ratio compared to control plots at least at the study site Neuhaus, even though not significant, is another evidence.

Besides being a helpful indicator for changes in nutrient availability (Schmidt 1991), the understorey vegetation is especially important in reducing leaching losses of excessively available nitrogen after disturbance and by this means for bringing the forest ecosystem back to a closed nitrogen cycle (Marks \& Bormann 1972; Mellert et al. 1998). This is also connected with a decreasing risk of acidification in the upper soil as the loss of nitrate is connected with a loss in base cations (Legout et al. 2009). The vegetation on clear cuts was more effective in reducing leaching losses than vegetation on selection cutting plots when comparing inorganic nitrogen concentrations in the soil leachate with concentrations measured under control plots despite a gain in aboveground biomass also after selection cutting. This increase, however, partially represents mosses (in 
particular in Otterbach) benefiting from a low degree of disturbance (Jonsson \& Esseen 1990). Small statured closed forest species such as Oxalis acetosella were as well persistent in their contribution to understorey abundance, while these species decrease on clear cuts in favour of multilayered ones (e.g. E. angustifoilum, D. purpurea). Elemans (2004) showed for some herbaceous forest species that the increase in nutrient availability is often only effective for biomass production under an efficient light availability; this seems also to be the case for forest generalists. In addition, the input of inorganic nitrogen from canopy throughfall, missing on clear cuts, is another source for the understorey vegetation (Gebauer et al. 2000) on selection cutting plots diminishing the soil uptake. On clear cuts the high radiation at the ground can lead to a desiccation of the upper soil inhibiting microorganisms and preventing mineralisation for some time. This risk is lower after selection cutting, where the canopy still gives shade and especially mosses can have an insulating effect (Bonan \& Shugart 1989). Klinck (2009) furthermore reported that roots of Picea abies trees, adjacent to the gaps, are not able to access the soil beneath gaps in a period of five years following tree removal. The establishment of nitrophilous small shrubs was, however, favoured by the soil disturbance caused during wood removal, but was not solely found in gaps.

Comparing both treatments on the stand level and considering higher amounts of rainfall reaching the clear cuts, total canopy removal will result in higher total nitrogen outputs than selection cutting. Over a period of 15 to 20 years, though, the repeated cuttings on selection cutting plots will probably cause similar outputs than clear cutting (Weis et al. 2006), dependent on regeneration development. In addition, neither management regime showed nitrate concentrations in the seepage above the European standard for drinking water at $50 \mathrm{mg} / \mathrm{l}$ as seen for example at the Höglwald with nitrate concentrations up to $100 \mathrm{mg} / \mathrm{l}$ after clear cutting (Huber et al. 2004; Weis et al. 2006). At this site a total removal of logging residues could have been beneficial, as such a treatment favours the understorey development (Stevens \& Hornung 1990). In the Solling a total removal seems unnecessary. Contrarily, leaving some woody debris on the plots could introduce a nutrient source compensating the impoverishment of available nitrogen detected within the soil, but also within the plant tissue four years after clear cutting, which could not be fully explained by the higher amount of structural tissue being produced under high irradiance (expressed by the plasticity of the LDMC). The establishment and growth of pioneer tree species probably contributed to this impoverishment by taking up nutrients from deeper soil layers (Wang et al. 1996). The 
lower nitrogen availability, however, also favours the further expansion of woody species following the structural carbon-nutrient balance hypothesis (Graves et al. 2006). It basically predicts that the success of woody species relative to herbaceous plants increases when the abundance of light relative to soil resources increases.

\section{Study site effects}

As mentioned in Chapter 2, both study sites differ slightly in climate, soil properties and in land use history; the studied stands were different in age and liming regime.

The more recent liming in Neuhaus (2001 compared to around 1990 in Otterbach) seems to promote the greatest differences in vegetation development. Schmidt (2002) showed that amelioration liming is connected with an increase in total species numbers as well as in non-forest species. This is reflected in vegetation surveys conducted before harvesting operations. A higher light availability as a consequence of the larger stand age in Neuhaus probably contributed to this higher diversity. Regarding individual species, Oxalis acetosella benefitted from amelioration liming with high cover values compared to Otterbach, which is in accordance with Rodenkirchen (1998). Mycelis muralis, showing higher abundances in Neuhaus too, was also mentioned as an indicator for liming by Zerbe (1993), while the higher abundance of Agrostis capillaris and Holcus mollis rather reflects the higher crown transparency. These grass species in combination with Vaccinium myrtillus probably give a first indication of the formerly existing heathland community (Seibert 1955). Simultaneously, Neuhaus is lacking a dense moss layer, whilst Otterbach is characterized by a large abundance of acidophilous moss species (e.g. Plagiothecium curvifolium, Polytrichum formosum), which are negatively affected by liming (Schmidt 2002). The frequent occurrence of Brachythecium rutabulum in Neuhaus (personal oberservation) is as well supporting an influence of the more recent liming on vegetation composition (Weckesser \& Schmidt 2004). Conflicting evidence gives Rubus idaeus, generally mentioned as being favoured by liming, but being more abundant in Otterbach (Schmidt 2002). However, the liming in 1990 might still show its effect in Otterbach. Furthermore, Zerbe (1993) mentions a large expansion of $R$. fruticosus often associated with an increase in $R$. idaeus in several low mountain ranges of Central Germany, independently from limed areas or sites affected by thinning. If the anthropogenic nitrogen deposition is the only reason for this, needs to be analysed. The shrub layer diversity was slightly higher in Otterbach despite the younger stand age. 
However, the availability of seed sources was much higher at this study site with oak, beech and sycamore trees in direct vicinity.

The mentioned initial differences in species composition were also reflected in the response after disturbance which was faster in Neuhaus. A larger pool of herb layer species was potentially able to expand under the changed environmental conditions, and thus influenced the species richness (Zobel 1997) and abundance on the small scale. In Otterbach, colonization was slower and establishment probably deterred by the persistent moss layer. This influenced also ecosystem functioning as the faster expansion of species with a fast nutrient uptake accelerated the return to a steady-state nutrient cycle in Neuhaus. Responsible species are for example Epilobium ciliatum or Senecio sylvaticus, but also the pioneer tree Salix caprea. It is favoured by a higher base supply following liming in addition with soil disturbance after wood harvest (Küßner 1997) and is, as well, characterized by a higher nitrate reductase activity than for example Betula pendula (Al Gharbi \& Hipkin 1984), which established successfully in Otterbach. Studies of ecosystem recovery after disturbance often detected that ecosystems with a higher diversity of response types showed a more rapid recovery (Hooper et al. 2005). This seems also to be the case comparing Neuhaus and Otterbach.

With increasing importance of tree species both study sites converge in terms of species composition and structure towards a pioneer forest on clear cuts, a pattern described by several authors before (Schölch et al. 1994; Gregor \& Seidling 1997; Sayer \& Reif 1998; Fischer \& Fischer 2009). Thus, the effect of initial site differences decreases over time and will have no lingering effect regarding forest development. Some species, reflecting the difference in land use, will however remain on clear cuts for a certain period (e.g. oak regeneration in Otterbach, the appearance of Calluna vulgaris, Genista germanica, Lathyrus linifolius in Neuhaus) and contribute to small scale diversity.

\section{Implications for future forest management}

According to the long-term forest development program of Lower Saxony (LÖWE), the transformation of even-aged Norway spruce stands into mixed stands should only be achieved using a close-to-nature management regime. The removal of single target diameter trees is thought to maintain the multifunctional forest ecosystem as it supposedly mimics small scale natural disturbances. Thus, this concept approaches a continuous cover forestry, proposed to achieve diverse and well structured forest ecosystems (Pommerening \& Murphy 2004). However, as mentioned above, such 
disturbance regime mainly characterizes natural beech forests, whilst natural spruce forests often suffer large scale disturbances. Thus, the question is, if the exclusive concentration on single tree selection cutting during the conversion of pure spruce stands into desired mixed forests is reasonable or if a management system such as clear cutting on a small scale can be a useful complement.

Regarding this study's results, clear cutting can be seen as an appropriate alternative. Indeed, selection cutting preserved initial understorey community much more than clear cutting. There was, however, no qualitative reduction in closed forest species when regarding all analysed subplots. The proximity of closed forests will further improve the re-establishment of forest species as was shown by Dzwonko \& Gawroński (1994) for broadleaved forests in Poland. This implies however, that the size of a clear cut is restricted. Which clear cut size can represent a threshold for a successful recolonisation of species needs further investigation (Pawsons et al. 2006).

Fahey \& Puettmann (2008) also suggest the usage of a few larger gaps (0.4 ha in size) over multiple small gaps ( $0.1 \mathrm{ha}$ ) in order to achieve influences on ecosystem processes that are beneficial for the forest ecosystem. This could for example apply for tree regeneration species establishing more successfully following clear cutting. In particular species such as Betula pendula, Populus tremula, Salix caprea and Sorbus aucuparia have to be mentioned that have not been inhibited by superior competitors. Pioneers are often regarded as beneficial for the upcoming target trees. They offer shelter from light and frost, are an alternative diet for rodents, prevent a large expansion of graminoids, can repress regeneration of Norway spruce in favour of broadleaved species and are able to influence the growth of target trees positively (Kenk et al. 1991; Schölch et al. 1994; Küßner \& Riemer 2000; Pommerening \& Murphy 2004). In addition, pioneer trees can ameliorate soil properties based on their high quality litter, which shows a high turnover rate (Emmer et al. 2000; Zerbe \& Meiwes 2000). Thus, the integration of secondary succession processes into conversion strategies can be beneficial for the growth of target tree species, but also for the ecosystem as a whole. Thereby, Bergan (1987) cited in Kenk et al. (1991) showed that already a number of 150 birch trees per ha can be effective. This number will easily be reached at mesic sites with a sufficient water supply (Sayer \& Reif 1998) as found in the Solling, at drier sites an artificial introduction of pioneers could be appropriate to achieve a pioneer forest protective for planted regeneration. Clear cutting also enables the germination and successful recruitment of intermediate and shade-intolerant climax tree species from the vicinity 
(e.g. Acer pseudoplatanus, Larix decidua, Quercus spec.), which are unable to grow under a continuous canopy cover. These species in combination with the pioneer trees mentioned above can largely contribute to the intended mixed forest and enhance the stability and resilience in light of climate change (von Lüpke 2004).

Small gaps following selection harvest did not support such diversity within tree regeneration. In addition, the ground vegetation showed a decelerated response especially in terms of nutrient acquisition mainly as a consequence of a lower light availability supporting Fahey \& Puettmann's (2008) detected limited gap influence on the understorey vegetation. Therefore, target tree species such as beech, which shows a considerable growth even under a low light availability (Welander \& Ottosson 1998), and other shade-tolerant tree species (e.g. Douglas fir; von Lüpke 2004) should be integrated a considerable time before gap creation. Thus a fast reaction of the forest stand to increased levels of light is possible (Huber et al. 2004; Kölling et al. 2009). In addition, the trees have a growth advantage compared to Rubus species, expanding after thinning. According to Ammer \& Mosandl (2007), a successful early integration under Norway spruce can be achieved by planting and sowing. Apart from that, stands with a sufficient natural regeneration (for example as a result of some remnant beech trees) are especially suitable for selection cutting. As Hérault et al. (2004) pointed out, this will mainly account for base rich soils.

One advantage mentioned for selection cutting is the creation of a heterogeneous illumination regime, which enhances structural diversity and generates many ecological niches (Matthes \& Ammer 2000). However, in light of conversion, tree selection is applied over the whole stand, which leads to a homogenization and a reduction in $ß$ diversity among stands as demonstrated by Decocq et al. (2004b). Small scale clear cuttings within a forest landscape could promote the contrary. During the course of this study, small clear cuts offered a niche to the species Genista germanica and Lathyrus linifolius. They reflect the former heathland community and are classified endangered respectively close to endangered in Lower Saxony (Garve 2004). The same is true for Isolepis setacea (detected in the seed bank) and Viola palustris that benefit from light and moisture increase. They are characteristic for fens, rarely available in the current landscape, and can use clear cuts as an alternative habitat. This is not only true for plant species, but also for open habitat ground beetle (Huber \& Baumgarten 2005) and bird species such as the woodlark (Flade 1994), which can use clear cuts as a retreat. 
In conclusion, results of the present work could detect no overall negative impacts of clear cuts conducted on a small scale on understorey diversity, tree regeneration or nitrogen leaching in the Solling compared to single tree selection cutting. Specific site conditions regarding understorey composition have to be taken into account, however, as the development in terms of competitive graminoids and shrubs depends largely on the vegetation present before disturbance, whereas the seed bank under mature spruce stands plays only a minor role. Thus, during the intended Norway spruce conversion a mosaic of management regimes should be considered, resembling a natural mosaic of disturbance regimes which is known from natural spruce forests (Liu \& Hytteborn 1991; Fischer et al. 2002). This mosaic should contain small gaps in forest stands, where a sufficient natural regeneration is available or an early integration of shade-tolerant tree species is possible (e.g. in mature stands where the canopy opens up and light availability is sufficient), but also larger gaps up to small scale clear cuttings, which can function as a retreat for rare light demanding species and offer colonization sites for a diverse tree regeneration. Such more severe disturbance regimes should not solely be concentrated at susceptible sites, where a fast conversion is necessary. By applying such a mosaic, structural as well as species diversity at a small scale but especially at landscape scale could be increased, and forests that approach climate-adaptive forests described by Jenssen (2009) be produced. These forests are able to adapt to a changing climate by a shift in species abundances. Such plasticity is important regarding the uncertainty of future climate trends and the long-term perspective which is necessary for stand transformations.

\section{References}

Aerts, R., Berendse, F. 1988. The effect of increased nutrient availability on vegetation dynamics in wet heathlands. Vegetatio 76: 63-69.

Al Gharbi, A., Hipkin, C.R. 1984. Studies on nitrate reductase in British angiosperms I. A comparison of nitrate reductase activity in ruderal, woodland-edge and woody species. New Phytologist 97: 629-639.

Al-Mufti, M.M., Sydes, C.L., Furness, S.B., Grime, J.P., Band, S.R. 1977. A quantitative analysis of shoot phenology and dominance in herbaceous vegetation. Journal of Ecology 65: 759-791

Ammer, C., Mosandl, R. 2007. Which grow better under the canopy of Norway spruce planted or sown seedlings of European beech? Forestry 80: 385-395. 
Bagherzadeh, A., Brumme, R. and Beese, F. 2008. Temperature dependence of nitrogen mineralization and microbial status in $\mathrm{O}_{\mathrm{H}}$ horizon of a temperate forest ecosystem. Journal of Forest Research 19: 37-43.

Bonan, G.B., Shugart, H.H. 1989. Environmental Factors and Ecological Processes in Boreal Forests. Annual Review of Ecology and Systematics 20: 1-28.

Bossuyt, B., Heyn, M. \& Hermy, M. 2002. Seed bank and vegetation compositions of forest stands of varying age in central Belgium: consequences for regeneration of ancient forest vegetation. Plant Ecology 162: 33-48.

Burke,D.M., Elliott, K.A., Holmes, S.B., Bradley, D. 2008. The effects of partial harvest on the understorey vegetation of southern Ontario woodlands. Forest Ecology and Management 255: 2204-2212.

Covington, W.W. 1981. Changes in forest floor organic matter and nutrient content following clear cutting in northern hardwoods. Ecology 62: 41-48.

Decocq, G., Valentin, B., Toussaint, B., Hendoux, F., Saguez, R. \& Bardat, J. 2004a. Soil seed bank composition and diversity in a managed temperate deciduous forest. Biodiversity and Conservation 13: 2485-2509.

Decocq, G., Aubert, M., Dupont, F., Alard, D., Saguez, R., Wattez-Franger, A., De Foucault, B., Delelis-Dusollier, A. Bardat, J. 2004b. Plant diversity in a managed temperate deciduous forest: understorey response to two silvicultural systems. Journal of Applied Ecology 41: 1065-1079.

Degen, T., Devillez, F., Jacquemart, A.-L. 2005. Gaps promote plant diversity in beech forests (Luzulo-Fagetum), North Vosges, France. Annals of Forest Science 62: 429440.

Donoso, P.J., Nyland, R.D. 2006. Interference to hardwood regeneration in Northeastern North America: the effects of raspberries (Rubus spp.) following clearcutting and shelterwood methods. Northern Journal of Applied Forestry 23: 288-296.

Dzwonko, Z. \& Gawronski, S. 1994. The role of woodland fragments, soil types, and dominant species in secondary succession on the western Carpathian foothills. Vegetatio 111: 149-160.

Egler, F.E. 1954. Vegetation science concepts I. Initial floristic composition - a factor in old-field vegetation development. Vegetatio 4: 412-417.

Elemans, M. 2004. Light, nutrient and the growth of herbaceous forest species. Acta Oecologica 26: 197-202. 
Ellenberg, H. 1996. Vegetation Mitteleuropas mit den Alpen. 5. Auflage, Ulmer Verlag, Stuttgart.

Emmer, I.M., Wessel, W.W., Kooijman, A., Sevink, J., Fanta, J. 2000. Restoration of degraded Central-European Mountain forest soils under changing environmental circumstances. European Forest Institute Proceedings 33: 81-92.

Fahey, R.T., Puettmann, K.J. 2008. Patterns in spatial extent of gap influence on understory plant communities. Forest Ecology and Management 255: 2801-2810.

Firm, D., Nagel, T.A., Diaci, J. 2009. Disturbance history and dynamics of an old-growth mixed species mountain forest in the Slovenian Alps. Forest Ecology and Management 257: 1893-1901.

Fischer, A., Fischer, H.S. 2009. 25 Jahre Vegetationsentwicklung nach Sturmwurf - Eine Dauerbeobachtungsstudie im Bayrischen Wald. Forstarchiv 80: 163-172.

Fischer, A., Lindner, M., Abs, C., Lasch, P. 2002. Vegetation dynamics in Central European forest ecosystems (near-natural as well as managed) after storm events. Folia Geobotanica 37: 17-32.

Flade, M. 1994. Die Brutvogelgemeinschaften Mittel- und Norddeutschlands. IHW-Verlag, Eching.

Garnier, E., Cortez, J., Billès, G., Navas, M.-L., Roumet, C., Debussche, M., Laurent, G., Blanchard, A., Aubry, D., Bellmann, A., Neill, C. and Toussaint, J.-P. 2004. Plant functional markers capture ecosystem properties during secondary succession. Ecology 85: 2630-2637.

Garve, E. 2004. Rote Liste und Florenliste der Farn- und Blütenpflanzen in Niedersachsen und Bremen. Informationsdienst Naturschutz Niedersachsen 1: 1-76.

Gebauer, G., Zeller, B., Schmidt, G., May, C., Buchmann, N., Colin-Belgrand, M., Dambrine, E., Martin, F., Schulze, E.-D., Bottner, P. 2000. The fate of ${ }^{15} \mathrm{~N}$-labelled nitrogen inputs to coniferous and broadleaf forests. In: Schulze, E.-D. (ed.) Carbon and nitrogen cycling in European forest ecosystems. Ecological Studies 142: 144-170.

Graves, J.H., Peet, R.K. and White, P.S. 2006. The influence of carbon-nutrient balance on herb and woody plant abundance in temperate forest understories. Journal of Vegetation Science 17: 217-226.

Gregor, T., Seidling, W. 1997. 50 Jahre Vegetationsentwicklung auf einer Schlagfläche im osthessischen Bergland. Forstwissenschaftliches Centralblatt 116: 218-231. 
Hannerz, M., Hånell, B. 1993. Changes in the vascular plant vegetation after different cutting regimes on a productive peatland site in Central Sweden. Scandinavian Journal of Forest Research 8: 193-203.

Hannerz, M., Hånell, B. 1997. Effects on the flora in Norway spruce forests following clearcutting and shelterwood cutting. Forest Ecology and Management 90: 29-49.

Hérault, B., Thoen, D., Honnay, O. 2004. Assessing the potential of natural woody species regeneration for the conversion of Norway spruce plantations on alluvial soils. Annals of Forest Science 61: 711-719.

Homann, M., Engels, F. 1991. Was kommt nach dem Sturm? Allgemeine Forstzeitung 46: 630-633.

Hooper, D.U., Chapin III, F.S., Ewel, J.J., Hector, A., Inchausti, P., Lavorel, S., Lawton, J.H., Lodge, D.M., Loreau, M., Schmid, B., Setälä, H., Symstad, A.J., Vandermeer, J., Wardle, D.A. 2005. Effects of biodiversity on ecosystem functioning: a consensus of current knowledge. Ecological Monographs 75: 3-35.

Horsley S.B., Marquis, D.A. 1983. Interference by weeds and deer with Allegheny hardwood reproduction. Canadian Journal of Forest Research 13: 61-69.

Huber, C., Baumgarten, M. 2005. Early effects of forest regeneration with selective and small scale clear-cutting on ground beetles (Coleoptera, Carabidae) in a Norway spruce stand in Southern Bavaria (Höglwald). Biodiversity and Conservation 14: 1989-2007.

Huber, C., Weis, W., Baumgarten, M., Göttlein, A. 2004. Spatial and temporal variation of seepage water chemistry after femel and small scale clear-cutting in an $\mathrm{N}$-saturated Norway spruce stand. Plant and Soil 267: 23-40.

Jenssen, M. 2009. Der klimaplastische Wald - ökologische Grundlagen einer forstlichen Anpassungsstrategie. Forst und Holz 64: 14-17.

Jonsson, B.G., Esseen, P.-A. 1990. Treefall disturbance maintains high bryophyte diversity in a boreal spruce forest. Journal of Ecology 78: 924-936.

Kenk G., Menges, U., Bürger, R. 1991. Natürliche Wiederbewaldung von Sturmwurfflächen? Allgemeine Forstzeitung 46: 96-100.

Klinck, U. 2009. Kohlenstoffvorrat, Nährstoffvorräte, und Wasserdynamik nach forstlichen Eingriffen in Fichtenreinbeständen. Dissertation der Fakultät für Forstwissenschaften und Waldökologie, Universität Göttingen. 
Klinck, U., Fröhlich, D. and Meiwes, K.J. 2007. Zur Problematik der Quantifizierung von Cund N-Gehalten, $\mathrm{C} / \mathrm{N}$-Verhältnissen und C- und N-Vorräten der Humusauflage und des mineralischen Oberbodens. Allgemeine Forst- und Jagdzeitung 179: 1-7.

Knapp, H.D., Jeschke, L. 1991. Naturwaldreservate und Naturwaldforschung in den ostdeutschen Bundesländern. Schriftenreihe für Vegetationskunde 21: 21-54.

Kölling, C., Knoke, T., Schall, P., Ammer, C. 2009. Überlegungen zum Risiko des Fichtenanbaus in Deutschland vor dem Hintergrund des Klimawandels. Forstarchiv 80: 42-54.

Kompa, T., Schmidt, W. 2003. Buchenwald-Sukzession nach Windwurf auf Buntsandstein im südwestlichen Harzvorland. Tuexenia 23: 95-130.

Kondoh, M. 2001. Unifying the relationships of species richness to productivity and disturbance. Proceedings of the Royal Society London B 268: 269-271.

Küßner, R. 1997. Sukzessionale Prozesse in Fichtenbeständen (Picea abies) des Osterzgebirges - Möglichkeiten ihrer waldbaulichen Beeinflussung und ihre Bedeutung für einen ökologisch begründeten Waldumbau. Forstwissenschaftliches Centralblatt 116: 359-369.

Küßner, R., Riemer, B. 2000. Silvicultural aspects of the conversion of spruce forests of the Ore Mountains into mixed stands. European Forest Institute Proceedings 33: 135143.

Legout, A., Nys, C., Picard, J.-F., Turpault, M.-P., Dambrine, E. 2009. Effects of storm Lothar (1999) on the chemical composition of soil solutions and on herbaceous cover, humus and soils (Fougères, France). Forest Ecology and Management 257: 800-811.

Leuschner, C. 1998. Mechanismen der Konkurrenzüberlegenheit der Rotbuche. Berichte der Reinhold-Tüxen-Gesellschaft 10: 5-18.

Liu Qinghong, Hytteborn, H. 1991. Gap structure, disturbance and regeneration in a primeval Picea abies forest. Journal of Vegetation Science 2: 391-402.

Marks, P.L. and Bormann, F.H. 1972. Revegetation following forest cutting: Mechanisms for return to steady state nutrient cycling. Science 176: 914-915.

Matejek, B., Kohlpaintner, M., Gasche, R., Huber, C., Dannenmann, M., Papen, H. 2008. The small-scale pattern of seepage water nitrate concentration in an $\mathrm{N}$ saturated spruce forest is regulated by net $\mathrm{N}$ mineralization in the organic layer. Plant and Soil 310: 167-179. 
Matthes, U., Ammer, U. 2000. Conversion of Norway spruce (Picea abies) stands into mixed stands with Norway spruce and beech (Fagus sylvatica) - Effects on stand structure in two different test areas. European Forest Institute Proceedings 33: 7179.

Mayer, P. Abs, C., Fischer, A. 2004. Colonisation by vascular plants after soil disturbance in the Bavarian forest - key factors and relevance for forest dynamics. Forest Ecology and Management 188: 279-289.

McIntyre, S., Lavorel, S., Tremont, R.M. 1995. Plant life-history attributes: their relationship to disturbance response in herbaceous vegetation. Journal of Ecology 83: 31-44.

Mellert, K.H., Kölling, C. and Rehfuess, K.E. 1998. Vegetationsentwicklung und Nitrataustrag auf 13 Sturmkahlflächen in Bayern. Forstarchiv 69: 3-11.

Meyer, P., Tabaku, V., von Lüpke, B. 2003. Die Struktur albanischer Rotbuchen-Urwälder - Ableitungen für eine naturnahe Buchenwirtschaft. Forstwissenschaftliches Centralblatt 122: 47-58.

Olchev, A., Radler, K., Sogachev, A., Panferov, O., Gravenhorst, G. 2009. Application of a three-dimensional model for assessing effects of small clear-cuttings on radiation and soil temperature. Ecological Modelling 220: 3046-3056.

Pawson, S.M., Brockerhoff, E.G., Norton, D.A., Didham, R.K. 2006. Clear-fell harvest impacts on biodiversity: past research and the search for harvest size thresholds. Canadian Journal of Forest Research 36: 1035-1046.

Pommerening, A., Murphy, S.T. 2004. A review of the history, definitions and methods of continuous cover forestry with special attention to afforestation and restocking. Forestry 77: 27-44.

Prescott, C.E., Hope, G.D., Blevins, L.L. 2003. Effect of gap size on litter decomposition and soil nitrate concentrations in a high-elevation spruce-fir forest. Canadian Journal of Forest Research 33: 2210-2220.

Quinby, P.A. 2000. First-year impacts of shelterwood logging on understory vegetation in an old-growth pine stand in central Ontario, Canada. Environmental Conservation 27: 229-241.

Reich, P.B., Walters, M.B., Ellesworth, D.S. 1992. Leaf life-span in relation to leaf, plant, and stand characteristics among divers ecosystems. Ecological Monographs 62: 365392. 
Rodenkirchen, H. 1998. Evidence for a nutritional disorder of Oxalis acetosella L. on acid forest soils II. Diagnostic field experiments and nutrient solution studies. Plant and Soil 199: 153-166.

Rosenzweig, M. 1995. Species diversity in space and time. University Press, Cambridge.

Sayer, U., Reif, A. 1998. Entwicklung der Vegetation im überregionalen Vergleich. In: Fischer, A. (Ed.) Die Entwicklung von Wald-Biozönosen nach Sturmwurf, pp. 148-168.

Schmidt, W. 1991. Die Veränderung der Krautschicht in Wäldern und ihre Eignung als pflanzlicher Bioindikator. Schriftenreihe für Vegetationskunde 21: 77-96.

Schmidt, W. 2002. Einfluss der Bodenschutzkalkungen auf die Waldvegetation. Forstarchiv 73: 43-54.

Schölch, M., Eh, M., Kenk, G. 1994. Natürliche Wiederbewaldung von Sturmflächen. Allgemeine Forstzeitung 49: 92-95.

Seibert, P. 1955. Die Niederwaldgesellschaften des südwestfälischen Berglandes. Allgemeine Forst- und Jagdzeitung 126: 1-11.

Stevens, P.A. and Hornung, M. 1990. Effect of harvest intensity and ground flora establishment on inorganic N-leaching from a Sitka spruce plantation in North Wales, UK. Biogeochemistry 10, 53-66.

Strengbom, J., Näsholm, T., Ericson, L. 2004. Light, not nitrogen, limits growth of the grass Deschampsia flexuosa in boreal forests. Canadian Journal of Botany 82: 430435

Tilman, D. 1988. Plant Strategies and the dynamics and structure of plant communities. University Press, Princeton.

Ulanova, N.G. 2000. The effects of windthrow on forests at different spatial scales: a review. Forest Ecology and Management 135: 155-167.

Vitousek, P.M., Gosz, J.R., Grier, C.C., Melillo, J.M., Reiners, W.A. and Todd, R.L. 1979. Nitrate losses from disturbed ecosystems. Science 204: 469-474.

Von Lüpke, B. 2004. Risikominderung durch Mischwälder und naturnaher Waldbau: ein Spannungsfeld. Forstarchiv 75, 43-50.

Von Oheimb, G., Härdtle, W. 2009. Selection harvest in temperate deciduous forests: impacts on herb layer richness and composition. Biodiversity and Conservation 18: 271-287.

Wang, J.R., Zhong, A.L., Simard, S.W., Kimmins, J.P. 1996. Aboveground biomass and nutrient accumulation in an age sequence of paper birch (Betula papyrifera) in the 
Interior Cedar Hemlock zone, British Columbia. Forest Ecology and Management 83: 27-38.

Weckesser, M. 2003. Die Bodenvegetation von Buchen-Fichten-Mischbeständen im Solling - Struktur, Diversität und Stoffhaushalt. Cuvillier, Göttingen.

Weckesser, M., Schmidt, W. 2004. Gehen dem Luzulo-Fagetum die Trennarten verloren? Veränderungen der Bodenvegetation in bodensauren Buchenwäldern und Fichtenbeständen des Solling in mehr als drei Jahrzehnten. Tuexenia 24: 191-206.

Weis, W., Rotter, V. and Göttlein, A. 2006. Water and element fluxes during the regeneration of Norway spruce with European beech: Effects of shelterwood-cut and clear-cut. Forest Ecology and Management 224: 304-317.

Welander, N.T., Ottosson, B. 1998. The influence of shading on growth and morphology in seedlings of Quercus robur L. and Fagus sylvatica L. Forest Ecology and Management 107: 117-126.

Zerbe, S., 1993. Fichtenforste als Ersatzgesellschaften von Hainsimsen-Buchenwäldern. Berichte des Forschungszentrums Waldökosysteme A100: 1-173.

Zerbe, S., Meiwes, K.J. 2000. Zum Einfluss von Weichlaubhölzern auf die Vegetation und Auflagehumus von Fichenforsten - Untersuchungen in einem zwei Jahrzehnte alten Birken-Ebereschen-Vorwald im Hoch-Solling. Forstwissenschaftliches Centralblatt 119: 1-19.

Zobel, M. 1989. Secondary forest succession in Järvselja, southeastern Estonia: changes in field layer vegetation. Annales Botanici Fennici 26: 171-182.

Zobel, M. 1997. The relative role of species pools in determining plant species richness: an alternative explanation of species coexistence? Trends in Ecology and Evolution 12: 266-269.

Zobel, M, Kalamees, R., Püssa, K., Roosaluste, E. \& Moora, M. 2007. Soil seed bank and vegetation in mixed coniferous forest stands with different disturbance regimes. Forest Ecology and Management 250: 71-76. 


\section{Appendices}

Appendix 1

Appendix 2
Supplement to Chapter 3: Steffi Heinrichs \& Wolfgang Schmidt (2009) Short-term effects of selection and clear cutting on the shrub and herb layer vegetation during the conversion of even-aged Norway spruce stands into mixed stands. Forest Ecology and Management 258: 667-678 (also available online at www.sciencedirect.com/science/journal/ 03781127)

Supplement to Chapter 4.1: Steffi Heinrichs, Markus Bernhardt-Römermann \& Wolfgang Schmidt (2010) The estimation of aboveground biomass and nutrient pools of understorey plants in closed Norway spruce forests and on clear cuts. European Journal of Forest Research129: 613-624 (also available online at www.springerlink.com/content/f77 1m1708h887h20/10342_2010_Article_362_ESM.html) 


\section{Appendix 1}

\section{Results of the generalized linear mixed model procedure}

Table A1 Generalized linear mixed model results for the effects of treatment (control, selection cutting, clear cutting) within one year, the effects of study site (Neuhaus and Otterbach) within one year and treatment, and the effects of year $(2002,2004,2006,2007)$ within one treatment on shrub and herb layer species numbers. Shown are the estimates (Est.) and z-values for the intercepts 'control' for each year of observation, 'Neuhaus' for each year and treatment, and year '2002' for each treatment. Estimates, z-values and significance levels for selection cutting and clear cutting represent differences to the intercept 'control' within one year, for Otterbach differences to the intercept 'Neuhaus' within one year and treatment, for the years 2004-2007 differences to the intercept '2002' within one treatment.

\begin{tabular}{|c|c|c|c|c|c|c|c|c|}
\hline & \multicolumn{2}{|c|}{2002} & \multicolumn{2}{|c|}{2004} & \multicolumn{2}{|c|}{2006} & \multicolumn{2}{|c|}{2007} \\
\hline & Est. & $\mathrm{Z}$ & Est. & $\mathrm{Z}$ & Est. & $\mathrm{z}$ & Est. & $\mathrm{z}$ \\
\hline \multicolumn{9}{|l|}{ Shrub layer } \\
\hline Control & 0.4 & 1.3 & 0.3 & 1.5 & 0.6 & 4.8 & 0.6 & 4.6 \\
\hline Neuhaus & 0.3 & 0.7 & 0.3 & 0.7 & 0.6 & 2.0 & 0.6 & 2.0 \\
\hline Otterbach & 0.4 & 0.7 n.s. & 0.1 & 0.3 n.s. & 0.0 & 0.0 n.s. & 0.0 & 0.0 n.s. \\
\hline Year & 0.4 & 1.5 & -0.1 & -0.8 n.s. & 0.1 & 1.0 n.s. & 0.1 & 0.5 n.s. \\
\hline Selection cutting & -0.1 & -0.3 n.s. & 0.1 & 0.4 n.s. & 0.8 & $5.1^{* * *}$ & 1.0 & $7.5^{* * *}$ \\
\hline Neuhaus & 0.2 & 0.5 & 0.4 & 1.4 & 1.4 & 14.5 & 1.5 & 18.5 \\
\hline Otterbach & 0.3 & 0.6 n.s. & 0.2 & 0.6 n.s. & 0.2 & 1.2 n.s. & 0.3 & $2.7^{* *}$ \\
\hline Year & 0.4 & 1.3 & 0.1 & 0.7 n.s. & 1.1 & $5.6^{* * *}$ & 1.3 & $5.6^{* * *}$ \\
\hline Clear cutting & 0.4 & 1.4 n.s. & -0.1 & -0.3 n.s. & 1.3 & $8.1^{* * *}$ & 1.6 & $11.6^{* * *}$ \\
\hline Neuhaus & 0.4 & 0.9 & 0.0 & -0.1 & 1.8 & 1.4 & 2.1 & 34.4 \\
\hline Otterbach & 0.8 & 1.3 n.s. & 0.5 & 1.3 n.s. & 0.2 & $0.1 \mathrm{n} . \mathrm{s}$. & 0.2 & $2.0 *$ \\
\hline Year & 0.8 & 2.6 & -0.6 & $-3.5^{* * *}$ & 1.1 & $4.9 * * *$ & 1.3 & $5.0 * * *$ \\
\hline \multicolumn{9}{|l|}{ Herb layer } \\
\hline Control & 2.8 & 32.9 & 2.9 & 30.3 & 3.1 & 35.4 & 3.1 & 31.3 \\
\hline Neuhaus & 2.8 & 36.5 & 2.9 & 42.2 & 3.2 & 41.9 & 3.2 & 34.9 \\
\hline Otterbach & 0.0 & 0.3 n.s. & -0.1 & -0.5 n.s. & -0.2 & $-2.0 *$ & -0.2 & -1.8 n.s. \\
\hline Year & 2.8 & 52.1 & 0.0 & 0.7 n.s. & 0.3 & $3.8^{* * *}$ & 0.2 & $3.2^{* *}$ \\
\hline Selection cutting & 0.2 & 1.2 n.s. & 0.2 & 1.9 n.s. & 0.2 & $3.3^{* *}$ & 0.3 & $2.9^{* *}$ \\
\hline Neuhaus & 3.1 & 26.8 & 3.2 & 2.6 & 3.5 & 57.5 & 3.5 & 43.9 \\
\hline Otterbach & -0.3 & -1.5 n.s. & -0.2 & -0.1 n.s. & -0.2 & $-2.6^{* *}$ & -0.2 & -1.9 n.s. \\
\hline Year & 3.0 & 29.3 & 0.1 & 1.7 n.s. & 0.4 & $6.9 * * *$ & 0.4 & $6.5^{* * *}$ \\
\hline Clear cutting & 0.2 & 1.4 n.s. & 0.3 & $3.1^{* * *}$ & 0.4 & $5.2^{* * *}$ & 0.4 & $4.2^{* * *}$ \\
\hline Neuhaus & 3.1 & 32.7 & 3.4 & 61.1 & 3.7 & 70.5 & 3.7 & 64.3 \\
\hline Otterbach & -0.2 & -1.7 n.s. & -0.5 & $-6.1^{* * *}$ & -0.4 & $-5.3 * * *$ & -0.5 & $-5.4^{* * *}$ \\
\hline Year & 3.0 & 25.4 & 0.2 & $4.6^{* * *}$ & 0.5 & $8.8^{* * *}$ & 0.5 & $7.9^{* * *}$ \\
\hline
\end{tabular}

n.s. not significant, ${ }^{*} \mathrm{p}<0.05,{ }^{* *} \mathrm{p}<0.01,{ }^{* * *} \mathrm{p}<0.001$ 
Table A2 Generalized linear mixed model results for the effects of treatment (control, selection cutting, clear cutting) within one year, the effects of study site (Neuhaus and Otterbach) within one year and treatment, and the effects of year $(2002,2004,2006,2007)$ within one treatment on shrub and herb layer coverage. Shown are the estimates (Est.) and t-values for the intercepts 'control' for each year of observation, 'Neuhaus' for each year and treatment, and year '2002' for each treatment. Estimates, t-values and significance levels for selection cutting and clear cutting represent differences to the intercept 'control' within one year, for Otterbach differences to the intercept 'Neuhaus' within one year and treatment, for the years 2004-2007 differences to the intercept '2002' within one treatment.

\begin{tabular}{|c|c|c|c|c|c|c|c|c|}
\hline & \multicolumn{2}{|c|}{2002} & \multicolumn{2}{|c|}{2004} & \multicolumn{2}{|c|}{2006} & \multicolumn{2}{|c|}{2007} \\
\hline & Est. & $\mathrm{t}$ & Est. & $\mathrm{t}$ & Est. & $\mathrm{t}$ & Est. & $\mathrm{t}$ \\
\hline \multicolumn{9}{|l|}{ Shrub layer } \\
\hline Control & 3.6 & 1.6 & 3.8 & 2.5 & 4.8 & 2.1 & 4.9 & 1.6 \\
\hline Neuhaus & 3.5 & 1.3 & 5.4 & 1.8 & 6.4 & 2.0 & 7.3 & 2.0 \\
\hline Otterbach & 0.3 & 0.1 n.s. & -3.1 & -0.7 n.s. & -3.2 & -0.7 n.s. & -4.6 & -0.9 n.s. \\
\hline Year & 3.6 & 2.5 & 0.2 & 0.3 n.s. & 1.2 & 1.0 n.s. & 1.2 & $0.8 \mathrm{n} . \mathrm{s}$ \\
\hline Selection cutting & -0.5 & -0.2 n.s. & 0.2 & 0.1 n.s. & 11.1 & $4.1^{* * *}$ & 16.6 & $4.6^{* * *}$ \\
\hline Neuhaus & 3.6 & 1.7 & 5.1 & 2.1 & 14.9 & 2.5 & 18.3 & 2.5 \\
\hline Otterbach & -1.1 & -0.4 n.s. & -2.3 & -0.7 n.s. & 2.1 & 0.2 n.s. & 6.5 & 0.6 n.s. \\
\hline Year & 3.1 & 2.5 & 0.9 & 0.5 n.s. & 12.9 & $4.2^{* * *}$ & 18.5 & $5.0 * * *$ \\
\hline Clear cutting & 5.2 & $2.0^{*}$ & -0.7 & -0.4 n.s. & 12.1 & $4.4^{* * *}$ & 18.9 & $5.2 * * *$ \\
\hline Neuhaus & 8.9 & 1.4 & 2.2 & 0.9 & 14.8 & 5.8 & 21.4 & 5.8 \\
\hline Otterbach & -0.2 & 0.0 n.s. & 1.9 & 0.5 n.s. & 4.3 & 1.2 n.s. & 4.8 & 0.9 n.s. \\
\hline Year & 8.8 & 3.2 & -5.6 & $-4.9 * * *$ & 8.1 & $3.9 * * *$ & 15.0 & $5.9 * * *$ \\
\hline \multicolumn{9}{|l|}{ Herb layer } \\
\hline Control & 28.2 & 3.8 & 35.3 & 4.3 & 35.8 & 4.2 & 33.8 & 4.0 \\
\hline Neuhaus & 34.0 & 2.8 & 43.8 & 2.9 & 44.2 & 2.5 & 43.8 & 2.5 \\
\hline Otterbach & -11.0 & -0.6 n.s. & -17.0 & -0.8 n.s. & -16.7 & -0.7 n.s. & -19.8 & -0.8 n.s. \\
\hline Year & 28.6 & 3.5 & 6.7 & $3.6^{* * *}$ & 7.3 & $2.1^{*}$ & 5.1 & 1.2 n.s \\
\hline Selection cutting & -1.5 & -0.3 n.s. & 3.9 & 0.8 n.s. & 4.5 & 0.8 n.s. & 6.7 & 1.2 n.s. \\
\hline Neuhaus & 31.1 & 2.9 & 48.1 & 4.3 & 50.9 & 5.2 & 51.0 & 6.5 \\
\hline Otterbach & -8.8 & -0.6 n.s. & -17.9 & -1.1 n.s. & -21.1 & -1.5 n.s. & -21.1 & -1.9 n.s. \\
\hline Year & 26.7 & 3.8 & 12.4 & $7.0 * * *$ & 13.7 & $4.3^{* * *}$ & 13.8 & $3.5^{* * *}$ \\
\hline Clear cutting & 1.2 & 0.2 n.s. & -3.3 & -0.7 n.s. & 7.2 & 1.2 n.s. & 14.4 & $2.6 *$ \\
\hline Neuhaus & 32.7 & 5.5 & 41.2 & 6.6 & 50.0 & 8.4 & 53.8 & 9.3 \\
\hline Otterbach & -6.5 & -0.8 n.s. & -18.5 & $-2.1 *$ & -13.9 & -1.7 n.s. & -11.2 & -1.4 n.s \\
\hline Year & 29.4 & 6.5 & 2.5 & $2.4^{*}$ & 13.6 & $10.1^{* * *}$ & 18.8 & $12.2^{* * *}$ \\
\hline
\end{tabular}

n.s. not significant, ${ }^{*} \mathrm{p}<0.05,{ }^{* *} \mathrm{p}<0.01,{ }^{* * *} \mathrm{p}<0.001$ 
Table A3 Generalized linear mixed model results for the effects of treatment (control, selection cutting, clear cutting) within one year on shrub and herb layer species numbers. Shown are the estimates (Est.) and z-values for the intercept 'control' for each year of observation. Estimates, z-values and significance levels for selection cutting and clear cutting represent differences to the intercept 'control' within one year.

\begin{tabular}{|c|c|c|c|c|c|c|c|c|}
\hline & \multicolumn{2}{|c|}{2002} & \multicolumn{2}{|c|}{2004} & \multicolumn{2}{|c|}{2006} & \multicolumn{2}{|c|}{2007} \\
\hline & \multicolumn{8}{|c|}{ Neuhaus } \\
\hline & Est. & $\mathrm{z}$ & Est. & $\mathrm{z}$ & Est. & $\mathrm{z}$ & Est. & $\mathrm{z}$ \\
\hline \multicolumn{9}{|l|}{ Shrub layer } \\
\hline Control & 0.1 & 0.3 & 0.3 & 0.8 & 0.6 & 3.6 & 0.6 & 4.0 \\
\hline Selection cutting & 0.1 & 0.2 n.s. & 0.1 & 0.6 n.s. & 0.7 & $4.1^{* * *}$ & 0.9 & $6.1^{* * *}$ \\
\hline Clear cutting & 0.3 & 1.7 n.s. & -0.3 & -1.5 n.s. & 1.2 & $6.8^{* * *}$ & 1.5 & $11.0^{* * *}$ \\
\hline \multicolumn{9}{|l|}{ Herb layer } \\
\hline Control & 2.8 & 27.0 & 2.9 & 38.1 & 3.2 & 57.9 & 3.2 & 60.3 \\
\hline Selective cutting & 0.3 & $5.8^{* * *}$ & 0.27 & $5.3^{* * *}$ & 0.3 & $5.9^{* * *}$ & 0.3 & $6.3^{* *}$ \\
\hline \multirow[t]{3}{*}{ Clear cutting } & 0.3 & $6.0^{* * *}$ & 0.52 & $11.0^{* * *}$ & 0.5 & $11.8^{* * *}$ & 0.5 & $12.7^{* * *}$ \\
\hline & \multicolumn{8}{|c|}{ Otterbach } \\
\hline & Est. & $\mathrm{z}$ & Est. & $\mathrm{z}$ & Est. & $\mathrm{z}$ & Est. & $\mathrm{z}$ \\
\hline \multicolumn{9}{|l|}{ Shrub layer } \\
\hline Control & 0.6 & 2.3 & 0.4 & 1.3 & 0.6 & 4.0 & 0.6 & 4.2 \\
\hline Selection cutting & -0.1 & -0.3 n.s. & 0.2 & 0.4 n.s. & 0.9 & $4.4^{* * *}$ & 1.2 & $7.5^{* * *}$ \\
\hline Clear cutting & 0.5 & 1.5 n.s. & 0.1 & 0.2 n.s. & 1.4 & $6.7^{* * *}$ & 1.7 & $10.9^{* * *}$ \\
\hline \multicolumn{9}{|l|}{ Herb layer } \\
\hline Control & 2.9 & 29.3 & 2.8 & 37.7 & 2.97 & 37.8 & 3.0 & 29.4 \\
\hline Selection cutting & 0.0 & 0.1 n.s. & 0.1 & 1.1 n.s. & 0.3 & $2.3 *$ & 0.3 & $2.0 *$ \\
\hline Clear cutting & 0.0 & 0.3 n.s. & 0.1 & 0.7 n.s. & 0.3 & $2.7^{* *}$ & 0.3 & $2.1^{*}$ \\
\hline
\end{tabular}

Table A4 Generalized linear mixed model results for the effects of treatment (control, selection cutting, clear cutting) within one year on shrub and herb layer coverage. Shown are the estimates (Est.) and t-values for the intercept 'control' for each year of observation. Estimates, t-values and significance levels for selection cutting and clear cutting represent differences to the intercept 'control' within one year.

\begin{tabular}{|c|c|c|c|c|c|c|c|c|}
\hline & \multicolumn{2}{|c|}{2002} & \multicolumn{2}{|c|}{2004} & \multicolumn{2}{|c|}{2006} & \multicolumn{2}{|c|}{2007} \\
\hline & \multicolumn{8}{|c|}{ Neuhaus } \\
\hline & Est. & $\mathrm{t}$ & Est. & $\mathrm{t}$ & Est. & $\mathrm{t}$ & Est. & $\mathrm{t}$ \\
\hline \multicolumn{9}{|l|}{ Shrub layer } \\
\hline Control & 3.5 & 0.8 & 5.3 & 1.9 & 6.4 & 1.5 & 7.3 & 1.4 \\
\hline Selection cutting & 0.1 & 0.0 n.s. & -0.2 & -0.1 n.s. & 8.5 & $2.5^{* *}$ & 11.1 & $2.7^{* *}$ \\
\hline Clear cutting & 5.4 & 1.4 n.s. & -3.2 & -1.7 n.s. & 8.4 & $2.4^{*}$ & 14.2 & $3.5^{* * *}$ \\
\hline \multicolumn{9}{|l|}{ Herb layer } \\
\hline Control & 34.0 & 2.6 & 43.8 & 2.9 & 44.2 & 2.7 & 43.8 & 2.7 \\
\hline Selection cutting & -2.9 & 0.4 n.s. & 4.3 & 0.5 n.s. & 6.7 & 0.6 n.s. & 7.3 & $0.6 \mathrm{n} . \mathrm{s}$. \\
\hline \multirow[t]{3}{*}{ Clear cutting } & -1.4 & -0.2 n.s. & -2.5 & -0.3 n.s. & 5.8 & 0.5 n.s. & 10.1 & 0.8 n.s. \\
\hline & \multicolumn{8}{|c|}{ Otterbach } \\
\hline & Est. & $\mathrm{t}$ & Est. & $\mathrm{t}$ & Est. & $\mathrm{t}$ & Est. & $\mathrm{t}$ \\
\hline \multicolumn{9}{|l|}{ Shrub layer } \\
\hline Control & 3.7 & 1.3 & 2.3 & 1.3 & 3.3 & 1.2 & 2.6 & 0.6 \\
\hline Selection cutting & -1.2 & -0.3 n.s. & 0.5 & 0.2 n.s. & 13.7 & $3.5 * * *$ & 22.2 & $4.2^{* * *}$ \\
\hline Clear cutting & 5.0 & 1.2 n.s. & 1.8 & 0.7 n.s. & 15.8 & $4.0 * * *$ & 23.6 & $4.5^{* * *}$ \\
\hline \multicolumn{9}{|l|}{ Herb layer } \\
\hline Control & 23.0 & 6.7 & 26.8 & 5.8 & 27.5 & 6.1 & 23.7 & 16.8 \\
\hline Selection cutting & -0.7 & 0.1 n.s. & 3.4 & 0.5 n.s. & 2.3 & 0.4 n.s. & 6.2 & $3.2 * *$ \\
\hline Clear cutting & 3.2 & 0.7 n.s. & -4.1 & -0.6 n.s. & 8.6 & 1.3 n.s. & 18.9 & $9.7^{* * *}$ \\
\hline
\end{tabular}




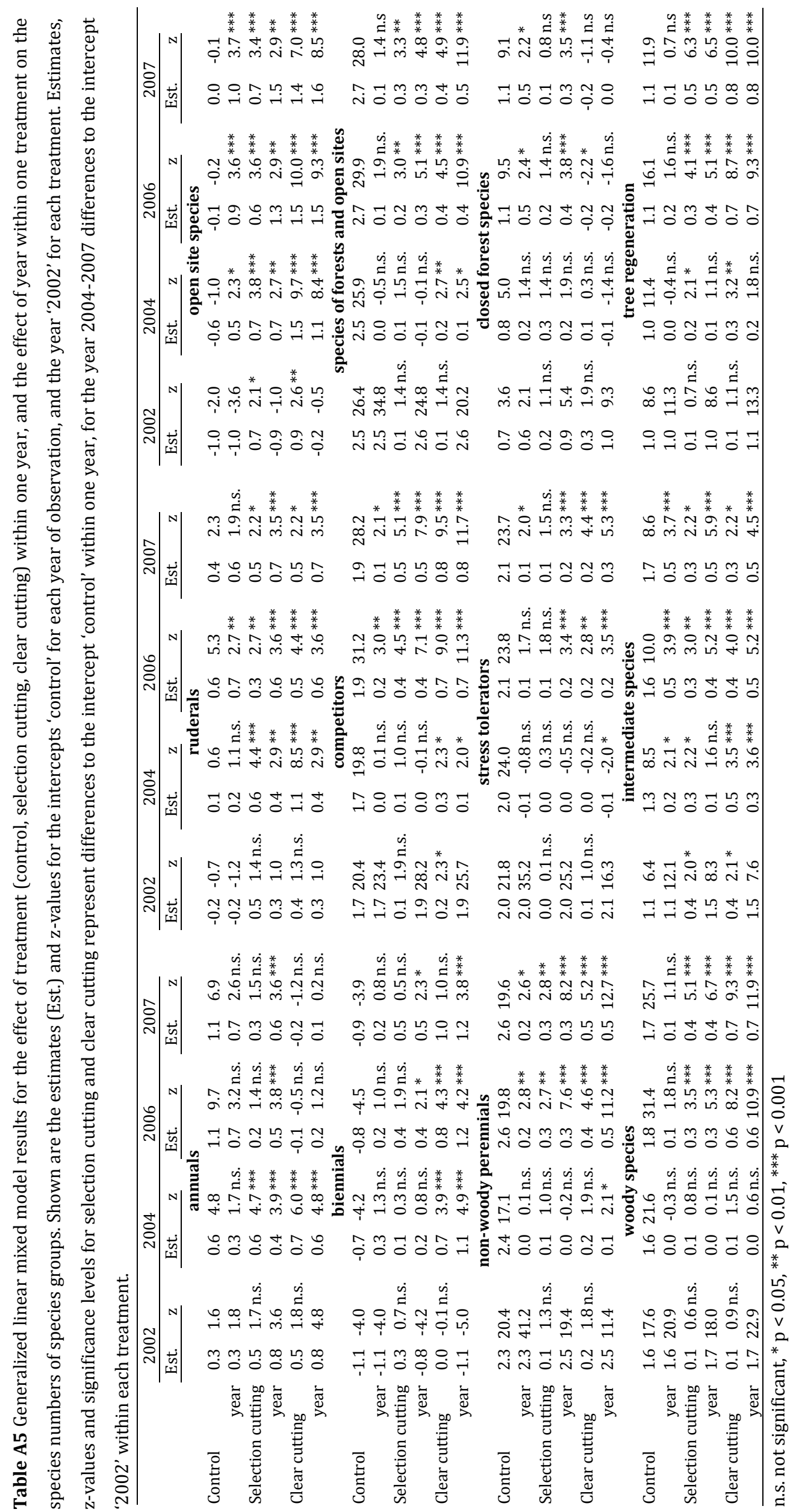




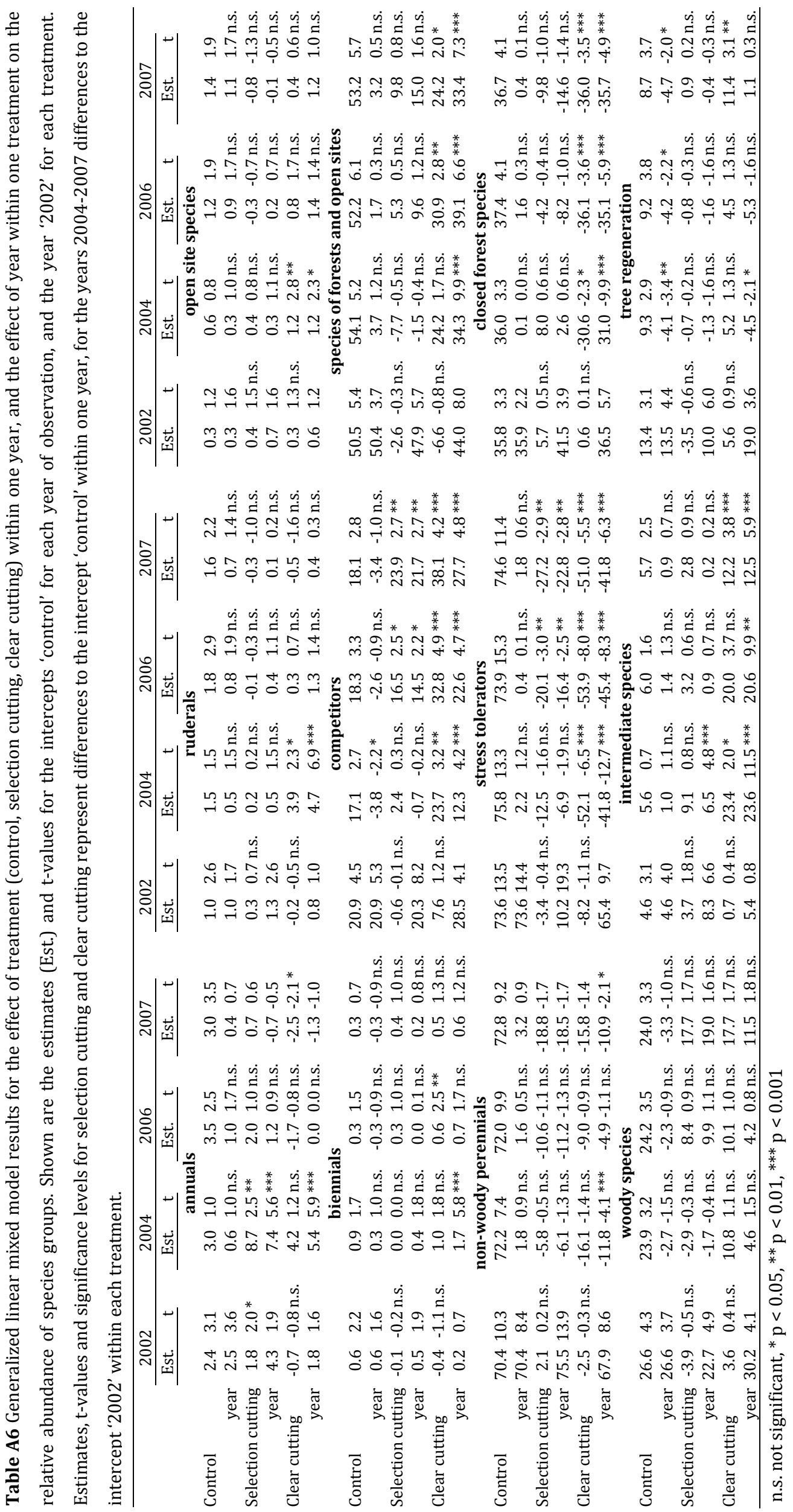




\section{Appendix 2}

Table A1 Regression functions estimating aboveground dry weight in $\mathrm{g} \mathrm{m}^{-2}$ from cover values and shoot length measurements for different morphological groups of forest understorey species and their adjusted coefficient of determination $\left(\mathrm{R}^{2}\right)$ according to Bolte $(2006, \text { modified })^{\mathrm{a}}$

\begin{tabular}{lcccccc}
\hline Morphological group & $\begin{array}{c}\text { Shoot length } \\
\text { range }[\mathrm{cm}]\end{array}$ & $\mathrm{n}$ & \multicolumn{3}{c}{ Regression coefficients } & \multirow{2}{*}{ adj. $\mathrm{R}^{2}$} \\
\cline { 4 - 6 } & & & $\mathrm{a}$ & $\mathrm{b}$ & $\mathrm{c}$ & 0.84 \\
Small herb & $5-15$ & 90 & 0.0373 & 0.7556 & 1.1897 & 0.88 \\
Middle herb & $10-40$ & 455 & 0.1033 & 0.9578 & 0.6213 & 0.78 \\
Tall herb & $20-160$ & 199 & 0.0212 & 1.0384 & 0.8631 & 0.89 \\
Small grass & $20-60$ & 158 & 0.0607 & 0.9389 & 0.8510 & 0.77 \\
Middle grass & $30-80$ & 228 & 0.0035 & 0.9576 & 1.5576 & 0.91 \\
Tall grass & $30-120$ & 173 & 0.0081 & 0.8805 & 1.3369 & 0.90 \\
Fern & $30-90$ & 52 & 0.0613 & 1.1977 & 0.4035 & 0.95 \\
Tall fern & $50-215$ & 48 & 0.0007 & 1.0991 & 1.5202 & 0.84 \\
Dwarf shrub & $10-40$ & 138 & 0.2178 & 0.8935 & 0.9167 & 0.84 \\
Small shrub & $25-120$ & 50 & 0.0342 & 0.9963 & 0.9887 & 0.81 \\
Pad moss & $1-10$ & 72 & 1.5814 & 1.0285 & 0.2378 & 0.82 \\
Mad moss $^{\mathrm{c}}$ & $5-10$ & 32 & 0.0519 & 0.8996 & 1.9514 & 0.96 \\
Dense moss $^{\mathrm{d}}$ & $4-8$ & 22 & 4.4864 & 1.0844 & 0.2567 & \\
\hline
\end{tabular}

a given are the range of shoot length values as well as the number of datasets (n) considered for each group during model calibration

bmainly acrocarpous moss species, e.g. Polytrichum formosum

cpleurocarpous moss species, e.g. Hypnum cupressiforme

ddense pads of Leucobryum spec.

Table A2 Element groups with their specific mean nutrient concentrations in $\mathrm{mg} \mathrm{g}^{-1}( \pm \mathrm{SD})$ used by PhytoCalc for nutrient pool estimations and one species example per element group (according to Bolte 2006, modified)

\begin{tabular}{lrrrr}
\hline Element group & $\mathbf{N}$ & $\mathbf{P}$ & $\mathbf{K}$ & Examples \\
\hline Herbs rich in calcium & 34.5 & 3.7 & 31.8 & Urtica dioica \\
Nutrient rich herbs & $( \pm 4.4)$ & $( \pm 1.8)$ & $( \pm 8.2)$ & \\
& 38.0 & 3.5 & 32.3 & Galium odoratum \\
Herbs rich in potassium & $( \pm 6.3)$ & $( \pm 0.8)$ & $( \pm 6.6)$ & \\
Nutrient poor herbs & 35.3 & 4.0 & 47.3 & Impatiens parviflora \\
Nutrient rich ferns & $( \pm 8.2)$ & $( \pm 1.1)$ & $( \pm 10.0)$ & \\
& 33.1 & 3.7 & 30.9 & Digitalis purpurea \\
Nutrient poor ferns & $( \pm 6.6)$ & $( \pm 1.4)$ & $( \pm 7.1)$ & \\
Rubus shrubs & 28.1 & 3.1 & 33.4 & Athyrium filix-femina \\
Dwarf shrubs & $( \pm 6.4)$ & $( \pm 0.9)$ & $( \pm 5.9)$ & \\
Mosses & 20.4 & 2.0 & 20.2 & Drypteris carthusiana \\
Nutrient rich grasses & $( \pm 3.1)$ & $( \pm 0.8)$ & $( \pm 3.7)$ & Rubus idaeus \\
Nutrient poor grasses & 18.5 & 1.6 & 9.6 & Vaccinium myrtillus \\
& $( \pm 4.3)$ & $( \pm 0.6)$ & $( \pm 4.4)$ & \\
& 12.9 & 1.0 & 5.3 & Hypnum cupressiforme
\end{tabular}




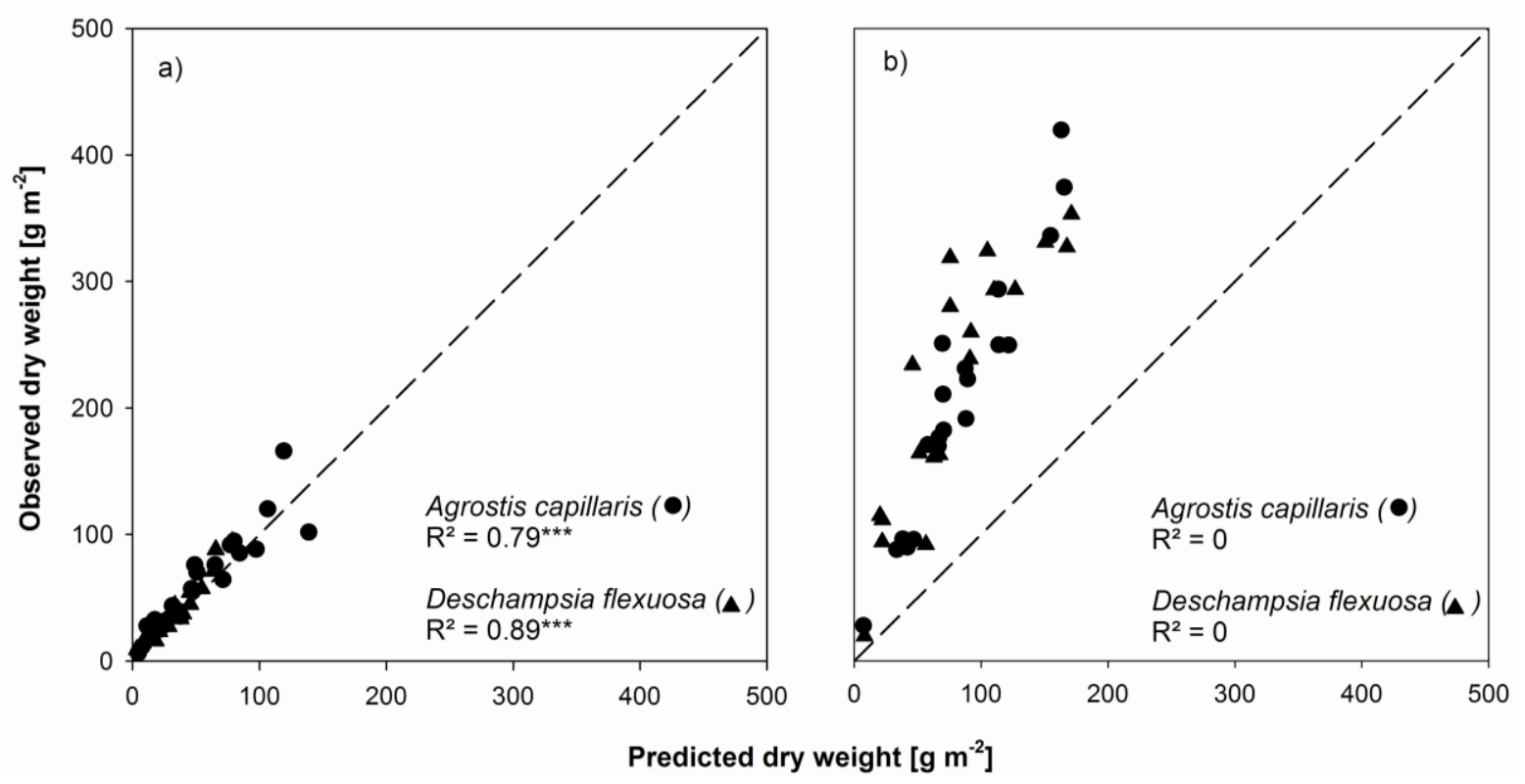

Fig. A1 Observed vs. predicted dry weights for A. capillaris $(\bullet)$ and D. flexuosa $(\boldsymbol{\Delta})$ sampled a) in closed Norway spruce stands and b) on clear cuts. The dashed line represents unity, the $\mathrm{R}^{2}$ values were calculated out of the variation around unity, ${ }^{* * *}$ indicates $\mathrm{p}<0.001$ 


\section{Curriculum Vitae}

Name

Date of Birth

Place of Birth

Nationality

\section{Education}

Since $04 / 2006$

$04 / 2009-08 / 2009$

$10 / 1999-08 / 2005$

$07 / 1993-07 / 1999$

$07 / 1999$

\section{Scientific working Experience}

Since $04 / 2006$

Research assistant at the Department of Silviculture and Forest Ecology of the Temperate Zones at the Georg-AugustUniversität Göttingen, Germany

$05 / 2002-08 / 2005$

$08 / 2002$
Steffi Heinrichs

22.05.1981

Zerbst/Anhalt (Germany)

German

Phd student in Biological Diversity and Ecology at the GeorgAugust-Universität Göttingen

Distance study course "European Environmental Law" at the University Koblenz-Landau, Germany; Certificate obtained

Study of Biology at the University of Bremen, Germany with the focus on Vegetation Ecology (main subject), Botany and Geography; Degree obtained: Diplom

Thesis: "Artenreichtum höherer Pflanzen auf Trockenrasen des nördlichen Harzvorlandes "

Heinrich-Heine-Gymnasium, Haldensleben

Abitur
Graduate assistant at the University of Bremen

Vegetation survey at the Drömling Nature Reserve, SaxonyAnhalt, Germany 



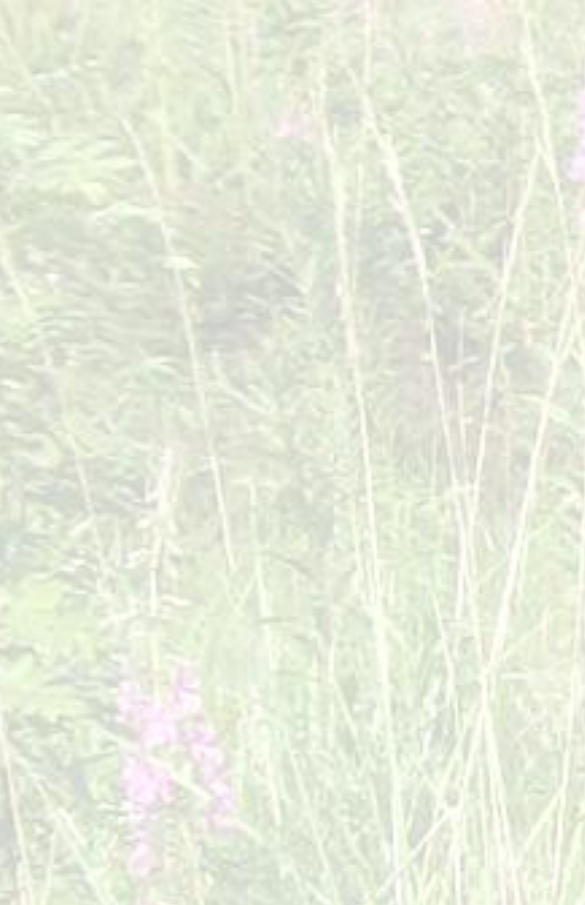

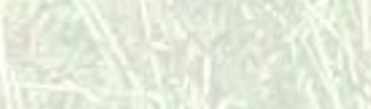

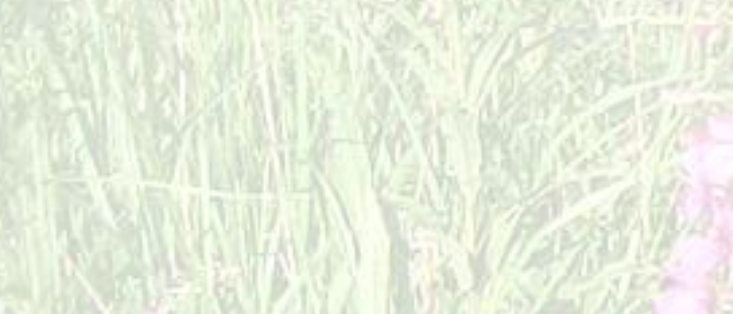

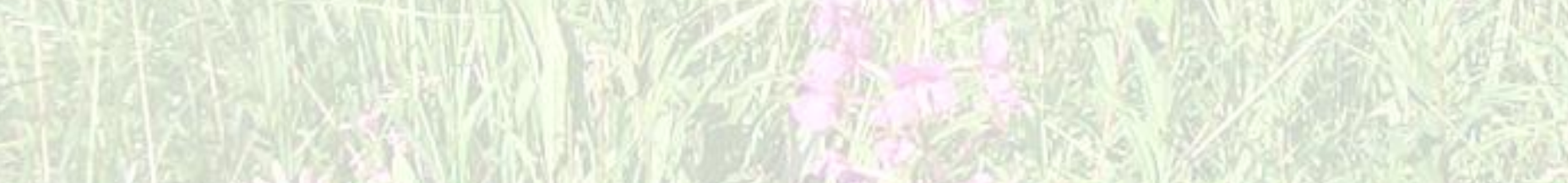
S.

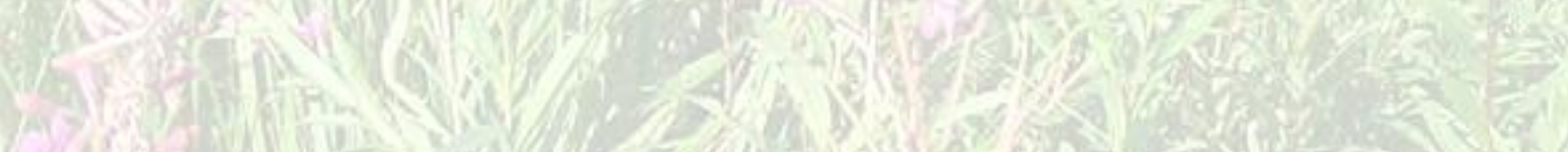

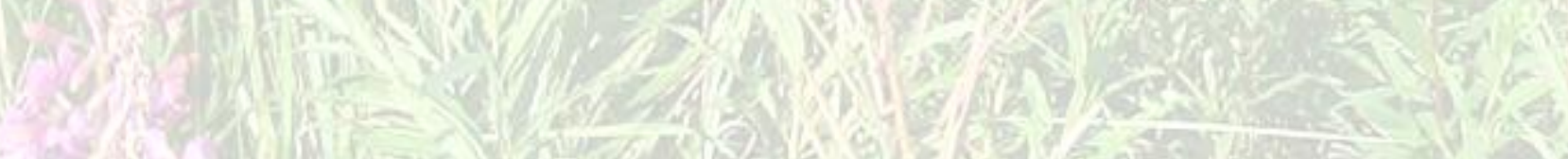

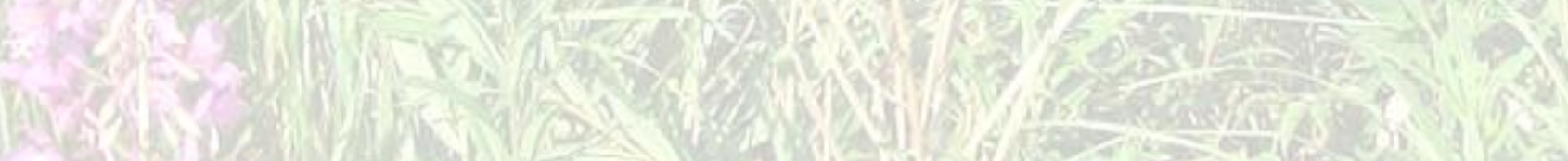

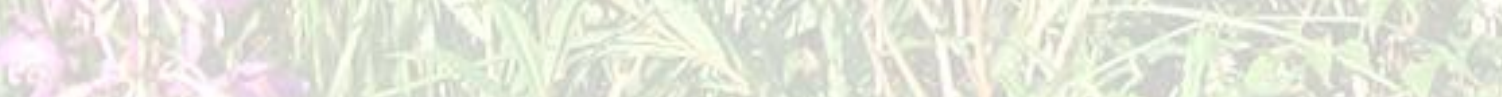

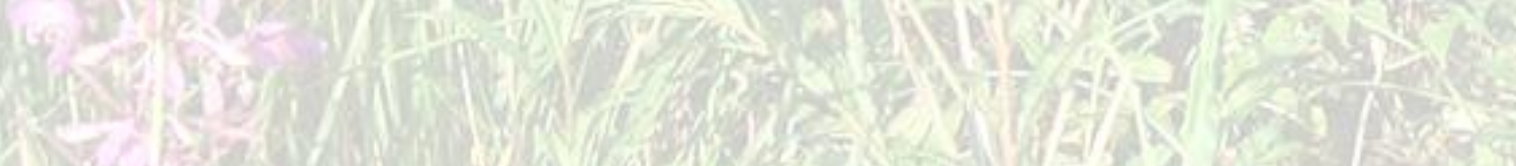

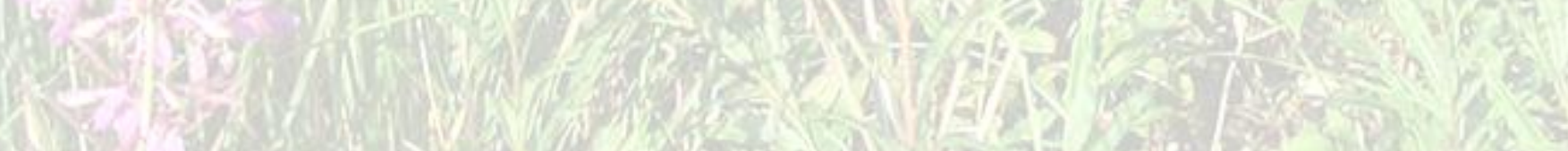

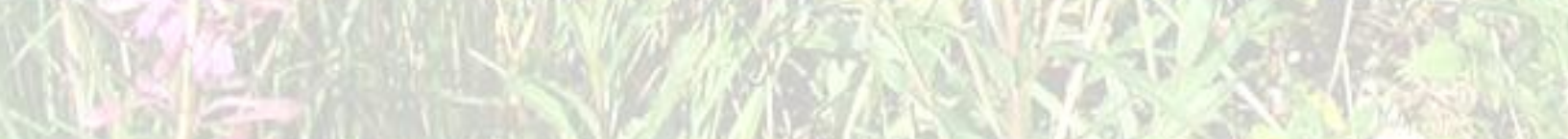

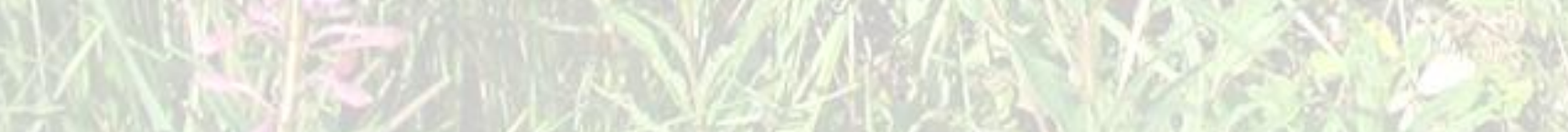

